on the lower elevations (IT and Consensus Planning, Inc. 1992) (Figure 3-7). The landsurface percent slope in the SNL/KAFB area varies from less than 1 percent to greater than 46 percent (Figure 4-5). Most mountain ridges trend to the northwest-southeast; therefore, many of the steep slopes face either southeast or northwest (Figure 4-6). Vegetation characteristics and slope affect the surface run-off and potential infiltration rates. Steep slopes facing the southeast receive more sunshine for longer periods of time than those facing northwest, possibly causing different evapotranspiration rates to occur on southeast-versus northwest-facing slopes. Currently, surface run-off characteristics and evapotranspiration rates in the area are not well understood.

Soils in the SNL/KAFB area are dominated by well-drained, loamy soils, with gravelly and stony soils along the arroyos and on the mountains (USDA Soil Conservation Service, 1977) (Figure 3-6) (see Section 3.3.1). The USDA Soil Conservation Service (1977) has designated the permeabilities (Figure 4-7) and available water capacities (Figure 4-8) of the soils in the area, based on the mapped soil textures. Permeabilities are mainly moderately slow to moderately rapid $[0.2$ to $6 \mathrm{in} . / \mathrm{hr}(.5$ to $15.2 \mathrm{~cm} / \mathrm{hr})]$ in the area, whereas the canyon bottoms and the Tijeras Arroyo flood plains exhibit rapid [6 to $20 \mathrm{in.} / \mathrm{hr}$ (15.2 to $50.8 \mathrm{~cm} / \mathrm{hr}$ )] permeabilities. Available water capacity is inversely correlated with the permeabilities (i.e., high water capacity corresponds with low permeability, as in a clayey soil). Infiltration is more likely to occur in areas with high permeabilities than areas with low permeabilities, where there is greater surface run-off potential. Note that regions where no permeability data exist (Figure 4-7) are classified as rock outcrop (Figure 3-6), which might have very low matrix permeabilities. If the rock outcrops are fractured, the fractureflow permeabilities might be very high, creating zones at high elevations (which correspond with the highest annual precipitation) at which large infiltration into the system could occur. The actual surface and subsurface conditions of the rock outcrop areas are unknown.

The vadose zone generally consists of unconsolidated valley-fill deposits. The valley fill consists of unconsolidated and semiconsolidated sands, gravels, silts, and clays of the Santa Fe Group (see Section 3.1.2). On the west side of the SNL/KAFB area, the valley fill is composed of highly heterogeneous alluvial fan, fluvial, and aeolian deposits. Farther west of SNL/NM facilities, the distal alluvial fan materials interfinger with generally finer Rio Grande sediments. In the eastern portion of the SNL/KAFB area, there might be areas where the vadose zone is composed of bedrock materials (e.g., Precambrian, Pennsylvanian, or Permian Formations) of relatively low permeability, but that might be highly fractured (see Section 3.1.1).

As previously discussed, the vadose zone thickness in this area is generally quite large. The depth to groundwater, and hence vadose zone thickness, appears to be strongly controlled by the Sandia Fault, Hubbell Spring Fault, and Tijeras Fault systems (Figure 4-9). In areas west of the faults, the vadose zone is typically on the order of 300 to $500 \mathrm{ft}$ ( 91 to $152 \mathrm{~m}$ ) thick, whereas east of the faults, the vadose zone thickness ranges from about 50 to $140 \mathrm{ft}$ (15 to $43 \mathrm{~m}$ ) according to water levels recorded in monitor wells (SNL/NM 1993). Note that east of the fault zone there are significant areas where bedrock is outcropping and where seeps and springs indicate much smaller depths to groundwater (see Figure 4-4). 

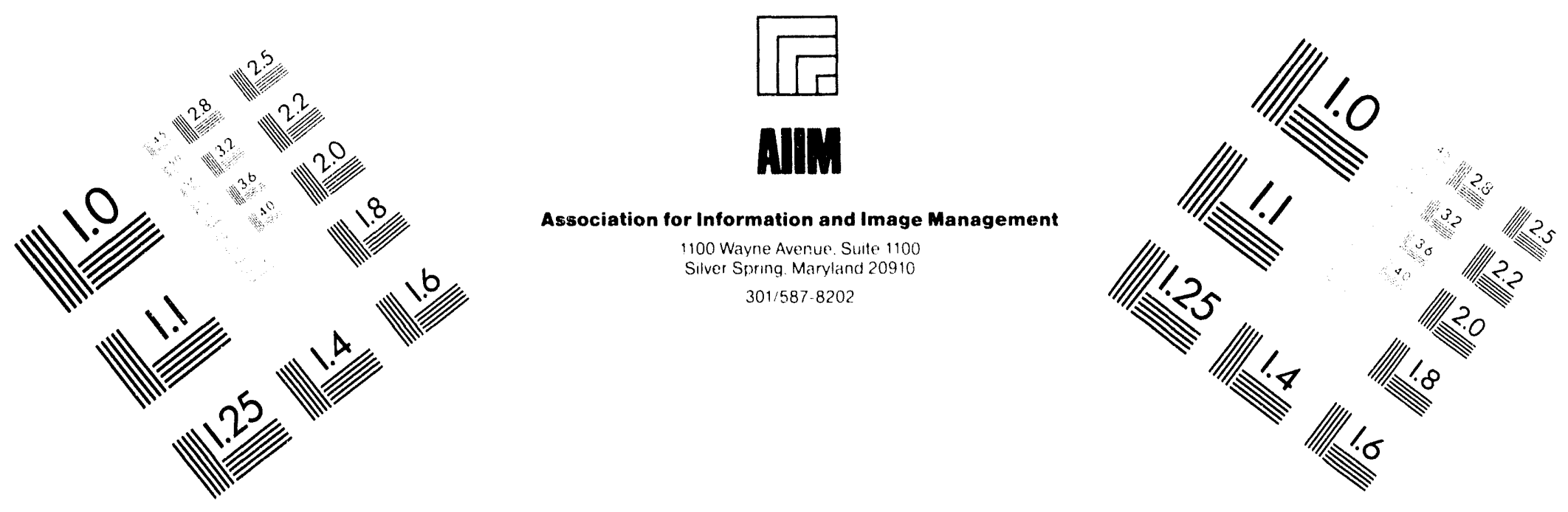

\section{Centimeter}

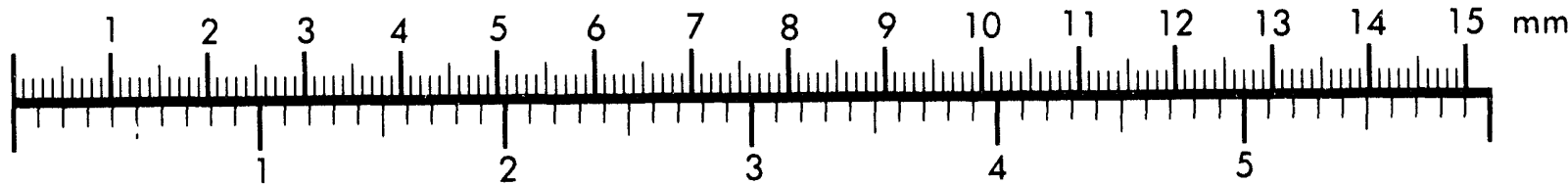
Inches
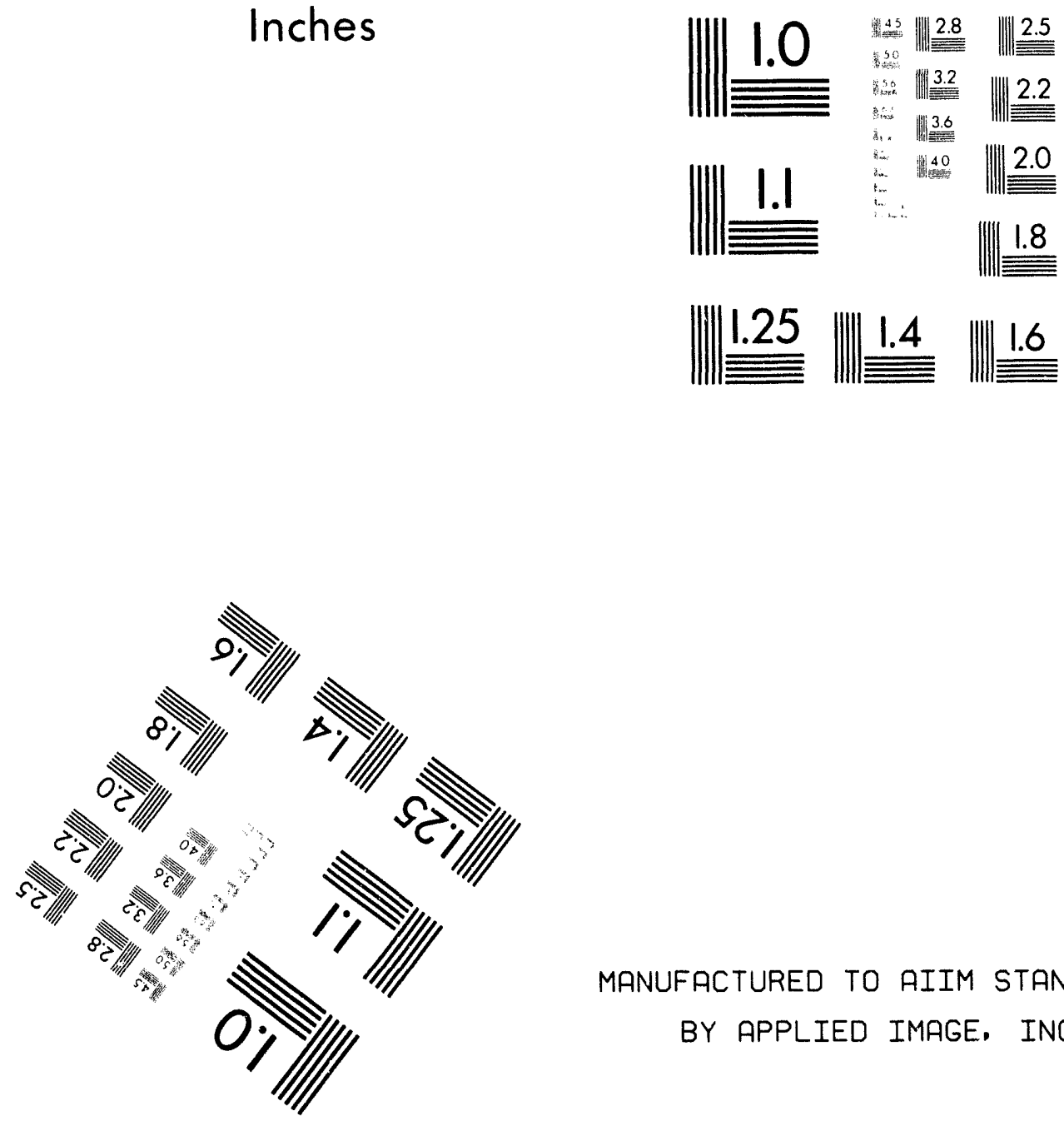

MANUFACTURED TO AIIM STANDARDS

BY APPLIED IMAGE. INC.

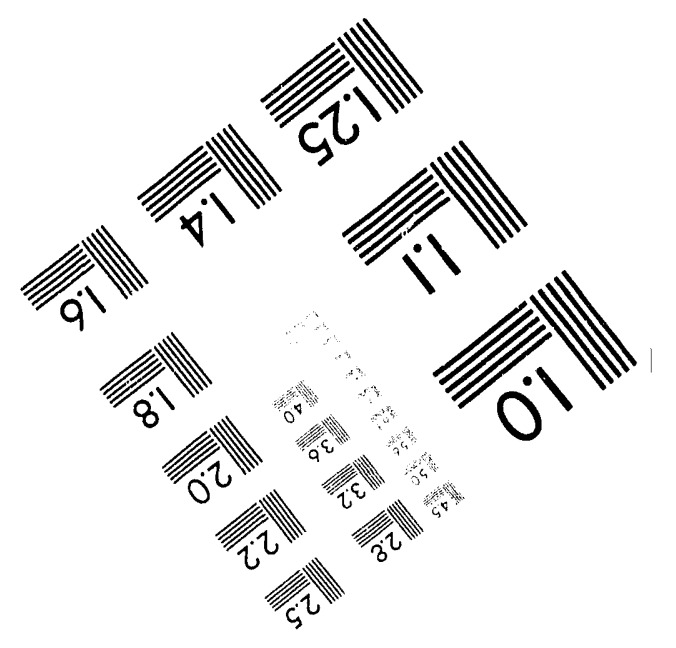



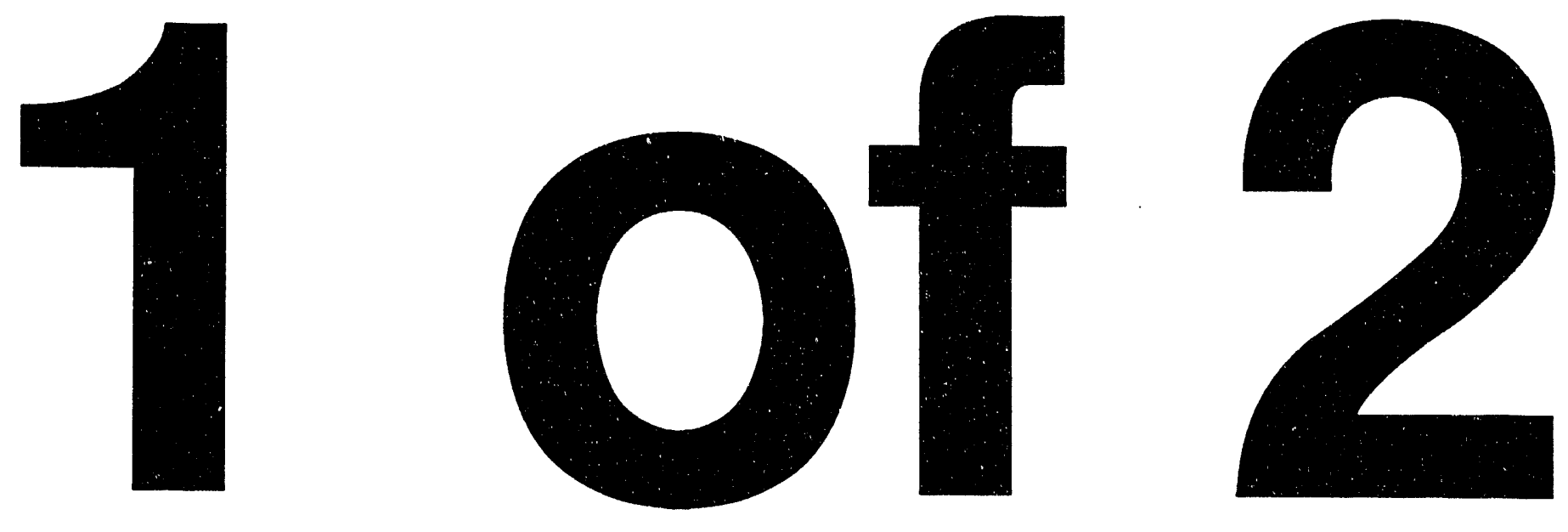
SAND93-0681

Unlimited Release

Printed October 1993

Category UC-403

\title{
SANDIA NATIONAL LABORATORIES SITE-WIDE HYDROGEOLOGIC CHARACTERIZATION PROJECT CALENDAR YEAR 1992 ANNUAL REPORT
}

\author{
D. Crowson, J.D. Gibson, C.S. Haase, R. Holt, D. Hyndman, \\ J. Krumhansl, F. Lauffer, J.P. McCord, J.T. McCord, D. Neel, \\ A.M. Parsons, R. Thomas
}

Sandia National Laboratories

Albuquerque, NM 87185

\begin{abstract}
The Sandia National Laboratories, New Mexico (SNL/NM) Site-Wide Hydrogeologic Characterization (SWHC) project has been implemented as part of the SNL/NM Environmental Restoration (ER) Program to develop the regional hydrogeologic framework and baseline for the approximately $100 \mathrm{mi}$ of Kirtland Air Force Base (KAFB) and adjacent withdrawn public lands upon which SNL/NM has performed research and development activities. Additionally, the SWHC project will investigate and characterize generic hydrogeologic issues associated with the 172 ER sites owned by SNL/NM across its facilities on KAFB. As called for in the Hazardous and Solid Waste Amendments (HSWA) to the Resource Conservation and Recovery Act (RCRA) Part B permit agreement between the U.S. Environmental Protection Agency (EPA) as the permitter and the U.S. Department of Energy (DOE) and SNL/NM as the permittees, an annual report is to be prepared by the SWHC project team. This document serves two primary purposes: (1) to identify and describe the conceptual framework for the hydrogeologic system underlying SNL/NM and (2) to describe characterization activities undertaken in the preceding year that add to our understanding (reduce our uncertainties) regarding the conceptual and quantitative hydrogeologic framework. This SWHC project annual report focuses primarily on purpose 1, providing a summary description of the current "state of knowledge" of the Sandia National Laboratories/Kirtland Air Force Base (SNL/KAFB) hydrogeologic setting.
\end{abstract}

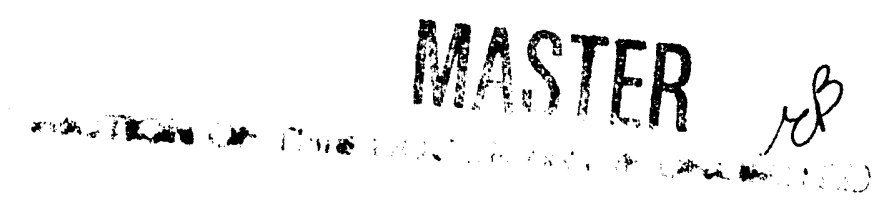




\section{ACKNOWLEDGMENTS}

\section{$\underline{\text { Editors }}$}

J. P. McCord, J. T. McCord, J. D. Gibson, and H. L. King

\section{Contributors}

D. Crowson

J. D. Gibson

C. S. Haase

R. Holt

D. Hyndman

J. Krumhansl

F. Lauffer

J. P. McCord

J. T. McCord

D. Neel

A. M. Parsons
R. Thomas

Sandia National Laboratories, Environmental Risk Assessment and Risk Managernent Department

Sandia National Laboratories, Geophysics Department

GRAM, Incorporated

INTERA, Incorporated

Lamb Associates, Incorporated

Sandia National Laboratories, Geochemistry Department

Sandia National Laboratories, Environmental Restoration Department

INTERA, Incorporated

Sandia National Laboratories, Environmental Risk Assessment and Risk Management Department

GRAM, Incorporated

Sandia National Laboratories, Environmental Risk Assessment and

Risk Management Department

Science Applications International Corporation

\section{Authorship}

Sections 1.0

and 2.0

J. T. McCord

Section 3.0

D. Crowson, J. D. Gibson, C. S. Haase, R. Holt, D. Hyndman, J. Krumhansl, and J. P. McCord

Section 4.0

J. Krumhansl, F. Lauffer, J. P. McCord, D. Neel, A. M. Parsons, and R. Thomas

Section 5.0
J. P. McCord and J. T. McCord 


\section{CONTENTS}

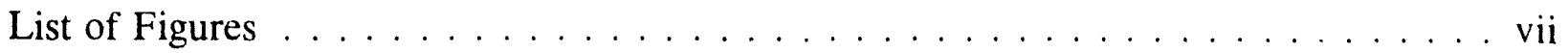

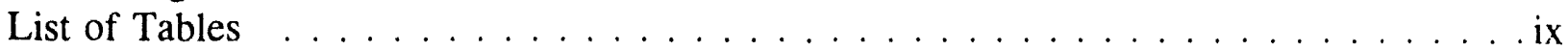

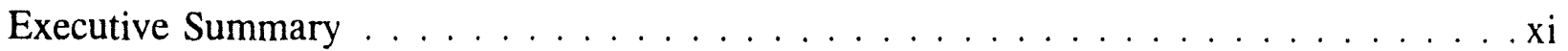

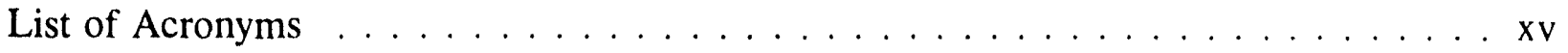

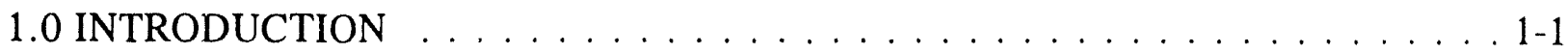

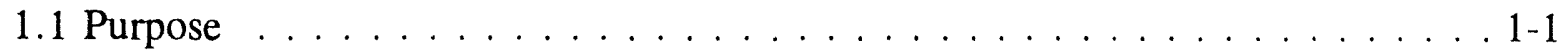

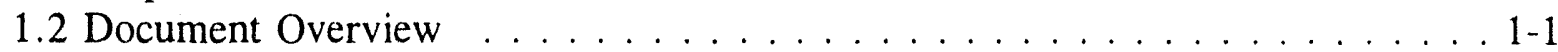

1.3 General Setting . . . . . . . . . . . . . . . . . . . .

1.3.1 Land Use . . . . . . . . . . . . . . . . . . . 1-2

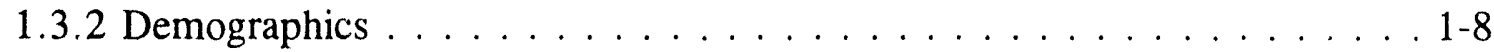

1.3 .3 History and Mission . . . . . . . . . . . . . . . 1-8

1.4 Calendar Year 1992 Characterization Activities Relevant

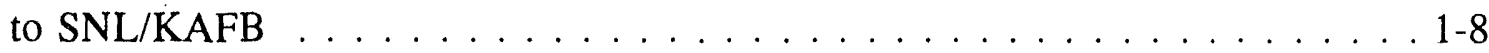

1.4.1 South Fence Road Hydrogeologic Wells . . . . . . . . . . . . . . . . . 1-9

1.4.2 Contaminant Characterization Activities at the SNL/NM

Chemical Waste Landfill . . . . . . . . . . . . . . . . . . . . . . 1-11

1.4.3 Contaminant Characterization Activities at the SNL/NM Mixed

Waste Landfill . . . . . . . . . . . . . . . . . . . . . . . . . 1-11

1.4.4 Contaminant Characterization Wells at the Technical Area V Liquid

Waste Disposal System . . . . . . . . . . . . . . . . . . . 1-11

1.4.5 Contaminant Characterization Well at Technical Area II . . . . . . . . . 1-11

1.4.6 Geologic Mapping of the Sanitary Sewer Line Trench . . . . . . . . . . 1-12

1.4.7 Geologic Mapping of the Travertine Hills . . . . . . . . . . . . . . 1-12

1.5 References . . . . . . . . . . . . . . . . . . . 1-12

2.0 QUANTITATIVE APPROACH TO SITE CHARACTERIZATION . . . . . . . . 2-1

2.1 Background and Previous Studies .................... 2-2

2.2 The SNL/NM ER Program, the SWHC Project, and Some Potential
Performance Criteria . . . . . . . . . . . . . . . . . . . . . . .

2.3 High-Level Identification of Significant Processes . . . . . . . . . . . . . . . . 2-4

2.4 Quantitative Approach to Identification and Selection of Characterization

Activities-5

2.5 Summary of Quantitative Approach to Site Characterization . . . . . . . . 2-7

2.6 References . . . . . . . . . . . . . . . . . . . . . . . . . . 2-9 


\section{CONTENTS}

(Continued)

$\underline{\text { Page }}$

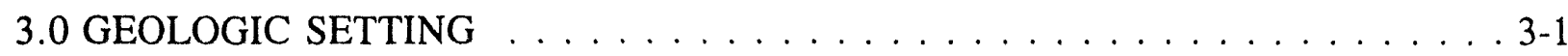

3.1 Stratigraphy and Geomorphology $\ldots \ldots \ldots \ldots \ldots \ldots$. . . . . . . .

3.1.1 Pre-Santa Fe Group . . . . . . . . . . . . . . . 3-1

3.1.1.1 Precambrian . . . . . . . . . . . . . . . . . 3-7

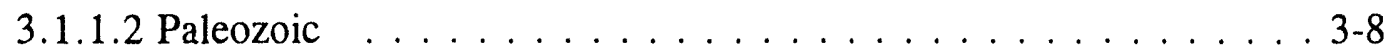

3.1.1.3 Pre-Santa Fe Group Cenozoic . . . . . . . . . . . . . . 3-9

3.1.2 Santa Fe Group . . . . . . . . . . . . . . . . . . . . . 3-9

3.1.2.1 Lower Santa Fe Group . . . . . . . . . . . . . . . . . . 3-11

3.1.2.2 Middle Santa Fe Group . . . . . . . . . . . . . . . 3-11

3.1.2.3 Upper Santa Fe Group . . . . . . . . . . . . . . . 3-11

3.1.3 Post-Santa Fe Group . . . . . . . . . . . . . . . . . . . . . . 3-11

3.1 .4 Geomorphology . . . . . . . . . . . . . . . 3-12

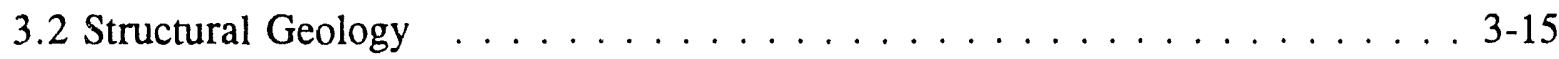

3.2 .1 Tijeras Fault $\ldots \ldots \ldots \ldots \ldots \ldots \ldots \ldots \ldots \ldots \ldots \ldots \ldots$

3.2 .2 Hubbell Spring Fault $\ldots \ldots \ldots \ldots \ldots \ldots \ldots . \ldots \ldots$. . . . . . . . . .

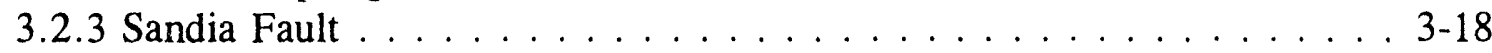

3.2.4 Manzano Fault . . . . . . . . . . . . . . . . . . . 3-20

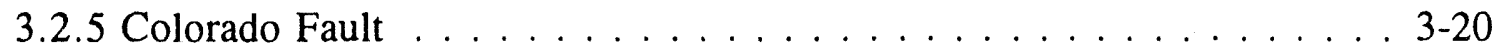

3.2 .6 Coyote Fault $\ldots \ldots \ldots \ldots \ldots \ldots \ldots \ldots \ldots \ldots \ldots \ldots \ldots$

3.2 .7 Other Faults . . . . . . . . . . . . . . . . . 3-21

3.3 Soils and Vegetation Within the SNL/KAFB Region $\ldots \ldots \ldots \ldots$. . . . . . .

3.3.1 Soils . . . . . . . . . . . . . . . . . 3-21

3.3 .2 Vegetation . . . . . . . . . . . . . . . . 3-27

3.4 Hydrogeologic Framework . . . . . . . . . . . . . . . . . . . . 3-27

3.4.1 Hydrostratigraphy . . . . . . . . . . . . . . . . 3-27

3.4.1.1 Lithofacies . . . . . . . . . . . . . . . . 3-33

3.4.2 Hydrogeologic Regions at SNL/KAFB . . . . . . . . . . . . . 3-39

3.4.3 Geologic Controls on Hydrologic Parameters . . . . . . . . . . . . 3-48 


\section{CONTENTS}

(Continued)

$\underline{\text { Page }}$

3.5 Travertine Hills Geology . . . . . . . . . . . . . . . . . . . . . . . 3-48

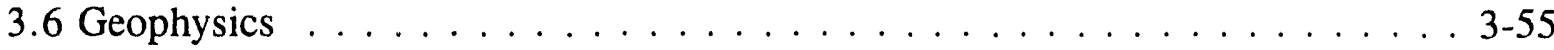

3.6.1 Geophysical Investigations for Defining Geologic Structure . . . . . . 3-55

3.6.1.1 Gravity Investigations $\ldots \ldots \ldots \ldots \ldots \ldots \ldots \ldots . \ldots \ldots$

3.6.1.2 Seismic Investigations . . . . . . . . . . . . . . . 3-57

3.6.1.3 Magnetic Investigations . . . . . . . . . . . . . 3-58

3.6.1.4 Electromagnetic Investigations . . . . . . . . . . . 3-58

3.6.2 Environmental Geophysics . . . . . . . . . . . . . . . 3-58

3.6.3 Geotechnical Investigations . . . . . . . . . . . . . . . 3-59

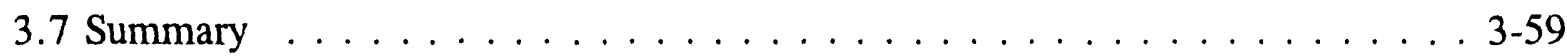

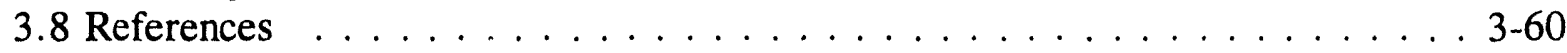

4.0 HYDROLOGIC SETTING $\ldots \ldots \ldots \ldots \ldots \ldots \ldots$. . . . . . . . . . . . . .

4.1 Meteorology $\ldots \ldots \ldots \ldots \ldots \ldots \ldots \ldots \ldots \ldots \ldots \ldots$. . . . . . . . . . .

4.1.1 Summary of Climate $\ldots \ldots \ldots \ldots \ldots \ldots \ldots \ldots \ldots$ 4-1

4.1.2 Meteorological Monitoring . . . . . . . . . . . . . . 4-5

4.1.3 Additional Data or Studies Needed . . . . . . . . . . . . . . . . 4-6

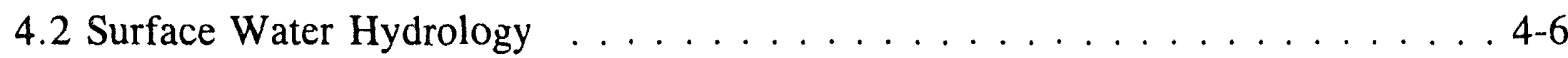

4.2.1 Surface Water Setting . . . . . . . . . . . . . . . . . . 4-6

4.2.2 Surface Water Monitoring and Investigations . . . . . . . . . . . 4-9

4.2.3 Additional Data or Studies Needed . . . . . . . . . . . . . . . . . 4-19

4.3 Vadose Zone Hydrology . . . . . . . . . . . . . . . . . . . . . . 4.20

4.3.1 Vadose Zone Hydrogeologic Framework . . . . . . . . . . . . . . . 4-21

4.3.2 Flow and Transport Processes and Parameters . . . . . . . . . 4 4-32

4.3.2.1 Previous Studies . . . . . . . . . . . . . . . 4-33

4.3.2.2 Calendar Year 1992 Studies . . . . . . . . . . . . . . 4-36

4.3.3 Additional Needs: Vadose Zone Characterization Plan . . . . . . . . 4 4-37

4.4 Saturated Zone Hydrology . . . . . . . . . . . . . . . . . . . . 4-37

4.4.1 Regional Hydrology . . . . . . . . . . . . . . . . . . . . 4-38

4.4.2 SNL/KAFB Saturated Zone Hydrogeologic Framework . . . . . . . 4-39 


\section{CONTENTS}

(Concluded)

Page

4.4.2.1 Subareas 1 and 2: Santa Fe Group Framework . . . . . . . 4-39

4.4.2.2 Subarea 3: Fault Complex Framework . . . . . . . . . . 4-51

4.4.2.3 Subarea 4: Paleozoic/Precambrian Bedrock Framework . . . . 4-55

4.4.3 Flow Parameters . . . . . . . . . . . . . . . . . 4-56

4.4.3.1 Santa Fe Group . . . . . . . . . . . . . . . . 4-58

4.4.3.2 Paleozoic/Precambrian Bedrock . . . . . . . . . . 4-58

4.4.4 Flow Direction . . . . . . . . . . . . . . . . . . . 4-59

4.4.4.1 Horizontal Gradients . . . . . . . . . . . . . . . . . 4-60

4.4 .4 .2 Vertical Gradients . . . . . . . . . . . . . . . . 4-60

4.4.5 Summary: Uncertainties and Plans $\ldots \ldots \ldots \ldots \ldots$. . . . . . . 4-62

4.5 Groundwater Chemistry . . . . . . . . . . . . . . . . 4-64

4.5.1 Regional Groundwater Chemistry . . . . . . . . . . . . . . 4-64

4.5.2 SNL/KAFB Groundwater Chemistry . . . . . . . . . . . . 4-65

4.6 References . . . . . . . . . . . . . . . . . . 4-71

5.0 HYDROGEOLOGIC CONCEPTUAL MODEL FOR THE SNL/KAFB AREA . . . 5-1

5.1 Integrated Conceptual Model . . . . . . . . . . . . . . . . . . 5-1

5.2 Uncertainties in the Conceptual Model . . . . . . . . . . . . . 5-3

5.2.1 Surface Water and Vadose Zone Uncertainties . . . . . . . . . . . . 5-3

5.2 .2 Saturated Zone Processes . . . . . . . . . . . . . . . . . 5-4

5.2.2.1 Aquifer-Type Identification . . . . . . . . . . . 5-4

5.2.2.2 Effective Hydraulic Parameters . . . . . . . . . . . . . 5-4

5.2 .2 .3 Hydraulic Gradients . . . . . . . . . . . . . 5-4

5.2 .2 .4 High-Permeability Flow Paths . . . . . . . . . . . 5-5

5.2 .2 .5 Transport Parameters . . . . . . . . . . . . . 5-5

5.2.2.6 Boundary Conditions at the Fault Complex $\ldots \ldots \ldots \ldots .5$

5.3 Conceptual Model to Quantitative Predictive Model . . . . . . . . . . . . . . 5-5

5.4 Summary of SNL/KAFB Hydrogeologic Modeling . . . . . . . . . . . 5-6

5.5 References . . . . . . . . . . . . . . . . . . . . . . .5-6 


\section{FIGURES}

Figure

$\underline{\text { Page }}$

1-1 General Location Map of SNL/NM . . . . . . . . . . . . . . 1-3

1-2 Location of SNL/NM ER Sites . . . . . . . . . . . . . . . 1-5

1-3 Land Ownership and Use Permits Within KAFB (including SNL) . . . . . . . . 1-7

1-4 Locations of 1992 ER Site Activities That Contributed to the SWHC . . . . . . 1-10

2-1 Flow Chart for Identification of Processes Requiring Characterization . . . . . 2 2-6

2-2 Summary of Decision Framework to Be Implemented as Part. of the SWHC . . 2-8

3-1 Tectonic Map of the Albuquerque Basin, North-Central New Mexico . . . . . . 3-2

3-2 Diagrammatic Geologic Cross Sections of the Central Albuquerque Basin

North and South of the Tijeras "Accommodation" Zone . . . . . . . . . . . 3-3

3-3 Stratigraphic Nomenclature Chart, Albuquerque Area . . . . . . . . . . . . . 3-5

3-4 Major Structural Features of the SNL/KAFB Region . . . . . . . . . . . . . 3-10

3-5 Location Map of SNL/KAFB Sanitary Sewer Trench Study . . . . . . . . . . . 3-13

3-6 Generalized Soils Classification for SNL/KAFB . . . . . . . . . . . . . . . 3-23

3-7 Generalized Vegetation Types for SNL/KAFB . . . . . . . . . . . . . . . . . . 3-29

3-8 Isopach Map of the Entire Santa Fe Group in the Albuquerque Area . . . . . . 3 3-31

3-9 Isopach Map of the Lower Santa Fe Group in the Albuquerque Area . . . . . . 3 3-32

3-10 Isopach Map of the Middle Santa Fe Group in the Albuquerque Area . . . . . . 3-34

3-11 Isopach Map of the Upper Santa Fe Group in the Albuquerque Area . . . . . 3 3-35

3-12 Hypothetical Distribution of Hydrostratigraphic Units in the Albuquerque Basin 3-36

3-13 Hypothetical Distribution of Lithofacies in the Albuquerque Basin . . . . . . . 3-38

3-14 Hydrogeologic Map of the Albuquerque Mctropolitan Area, Northern

Albuquerque Basin, New Mexico . . . . . . . . . . . . . . . . . . . . . . 3-41

3-15 Gibson Hydrogeologic Cross Section for the Northern SNL/KAFB Area . . . . . 3-43

3-16 Pajarito Hydrogeologic Cross Section for the Southern SNL/KAFB Area . . . 3-45

3-17 Hydrogeologic Regions in the SNL/KAFB Area . . . . . . . . . . . . . . . 3-47

3-18 Index Map to the Travertine Hills Area Geologic Map . . . . . . . . . . . . . . 3-53

3-19 Locations of Gravity, Seismic, and CSAMT Data and Major Faults at KAFB3-56 3-56

4-1 Average Precipitation in the SNL/KAFB and Albuquerque Area . . . . . . . . . 4-3

4-2 Surface Water Features in the SNL/KAFB Area . . . . . . . . . . . . . . . 4-7

4-3 Flood-Prone Areas in Tijeras Arroyo and Arroyo del Ccvote SNL/KAFB . . . 4-11

4-4 Location of KAFB Area Wells and Springs . . . . . . . . . . . . . . . 4-15

4-5 Surface Slope of Terrain in the SNL/KAFB Area . . . . . . . . . . . . . . 4 4-23

4-6 Surface Aspect of Terrain in the SNL/KAFB Area . . . . . . . . . . . . . 4 4-25

4-7 Permeability of Soils in the SNL/KAFB Area . . . . . . . . . . . . . . . 4 4-27

4-8 Soil Water Capacity in the SNL/KAFB Area . . . . . . . . . . . . . . . . . . 4-29

4-9 Potentiometric Surface of the SNL/KAFB Area Based on July 1992

Monitoring-Well Water Level Measurements from the Data Points Shown . . . . 4-31 


\section{FIGURES}

(Concluded)

Figure

4-10 Flow Diagram of Recharge to and Discharge from the Basin-Fill Aquifer . . . 4-40

4-11 Potentiometric Surface of the Albuquerque Basin-Fill Aquifer . . . . . . . . . 4 4-41

4-12 Location of Subareas Considered in the SNL/NM Saturated Zone Characterization . . . . . . . . . . . . . . . . . . . . . . 4-42

4-13 Typical Lithologic Column for the Santa Fe Group in the South Fence Road Region . . . . . . . . . . . . . . . . . . . . . . . . . . . . . . 4-44

4-14 Relative Core Moisture Diagrams for South Fence Road Wells . . . . . . . . . 4-47

4-15 Water Pumped by KAFB Production Wells in 1992 . . . . . . . . . . . . . . . 4-49

4-16 Hydrographs for Two Monitoring Wells Within Subarea 1, 1992 . . . . . . . 4 4-50

4-17 Gravity Survey Transects . . . . . . . . . . . . . . . . . . . . . . . . 4-53

4-18 Land Surface Elevation and Predicted Top-of-Bedrock Elevation Along Transect $5 \ldots \ldots \ldots \ldots$. . . . . . . . . . . . . . . . . . 4-54

4-19 Technical Area III Potentiometric Surface Map, May 1992 . . . . . . . . . . . 4-61

4-20 Completion Schematic Showing Water Levels for the SFR-1 Monitoring Intervals . . . . . . . . . . . . . . . . . . . . . . . 4-63

4-21 Piper Diagram for the April 1991 Sampling Period . . . . . . . . . . . . . . . 4-68

4-22 Piper Diagram for the July 1991 Sampling Period . . . . . . . . . . . . . . . . 4-69

4-23 Piper Diagram for the October 1991 Sampling Period . . . . . . . . . . . . 4-70

5-1 Schematic Hydrogeologic Conceptual Model of the SNL/KAFB Area . . . . 5 5-2 


\section{TABLES}

Table

Page

1-1 Calendar Year 1992 Field Activities That Provided Data to the SWHC

Project

3-1 Soil Associations in the SNL/KAFB Region . . . . . . . . . . . 3-22

3-2 Classification of Soils in the SNL/KAFB Region . . . . . . . . . . . . . 3-25

3-3 Relationships of Soil Series and Vegetation in the SNL/KAFB Area . . . . . 3-28

3-4 Summary of Lithofacies' Compositions and Depositional Settings Used in

Figure $3-13 \ldots \ldots$. . . . . . . . . . . . . . . . . . . 3-37

3-5 Summary of Parameters That Influence Groundwater Production of Santa Fe Group Lithofacies . . . . . . . . . . . . . . . . . . . . . . . . 3-49

3-6 Lithologic and Water-Bearing Characteristics of Stratigraphic Units in the SNL/KAFB Study Area $\ldots \ldots \ldots \ldots \ldots \ldots \ldots \ldots$

4-1 Peak Discharges for COE Flood Hazard Study . . . . . . . . . . . . . . . 4 4-13

4-2 Stream Gauging Stations . . . . . . . . . . . . . . . . . . . . . 4-17

4-3 Stream Gauging Stations for Water Years 1988 to $1991 \ldots \ldots$. . . . . . . . 4-18

4-4 Core Unsaturated Hydraulic Property Tests . . . . . . . . . . . . . . . . . 4-34

4-5 Summary of Santa Fe Group Lithostratigraphic Data Obtained from 1992

ER Program Boreholes . . . . . . . . . . . . . . . . . . . . . . . . 4-45

4-6 Summary of South Fence Road Borehole Depths and Gravity Data

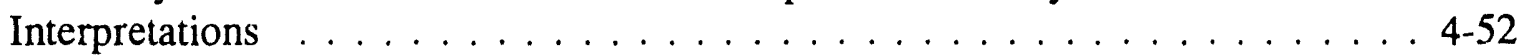

4-7 Identification of Boreholes in Subarea $4 \ldots \ldots$. . . . . . . . . . . . . .55

4-8 Summary of Hydrologic Characteristics of Boreholes in Subarea 4 . . . . . . . . . . . . . . . . . . . . . . . . . . . . . . . . . 4-57

4-9 Summary of Slug Test Results at the ITRI . . . . . . . . . . . . . . . 4-59

4-10 Summary of Water Chemistry for Selected Wells and Springs at KAFB . . . . 4-65

4-11 April 1991 SNL/KAFB Groundwater Sampling Results . . . . . . . . . . . . . 4-66 


\section{EXECUTIVE SUMMARY}

The Sandia National Laboratories, New Mexico (SNL/NM), Site-Wide Hydrogeologic Characterization (SWHC) project has been implemented as part of the SNL/NM Environmental Restoration (ER) Program to develop the regional hydrogeologic framework and baseline for the approximately $100 \mathrm{mi} 2$ of Kirtland Air Force Base (KAFB) and adjacent withdrawn public lands upon which SNL/NM has performed research and development activities. Additionally, the SWHC project will investigate and characterize generic hydrogeologic issues associated with the 172 ER sites owned by SNL/NM across its facilities on KAFB. Examples of generic issues exist in all components of the hydrogeologic system, including surface water (e.g., erosion), the vadose zone (e.g., groundwater recharge), and the saturated zone (e.g., regional groundwater flow to receptors).

As called for in the Hazardous and Solid Waste Amendments (HSWA) to the Resource Conservation and Recovery Act (RCRA) Part B permit agreement between the U.S. Environmental Protection Agency (EPA) as the permitter and the U.S. Department of Energy (DOE) and SNL/NM as the permittees, an annual report is to be prepared by the SWHC project team. This document serves two primary purposes:

1. To identify and describe the conceptual framework for the hydrogeologic system underlying SNL/NM.

2. To describe characterization activities undertaken in the preceding year that add to our understanding (reduce our uncertainties) regarding the conceptual and quantitative hydrogeologic framework.

This SWHC project annual report focuses primarily on purpose 1, providing a summary description of the current "state of knowledge" of the SNL/KAFB hydrogeologic setting. This summary description includes information obtained from all appropriate reports we are currently aware of, as well as from ER Program studies and projects, and summarizes the current understanding-and the associated uncertainties-of the occurrence, movement, and interaction of water in the geosphere. Additionally, this first annual report is an appropriate vehicle for communicating the rationale we will employ to identify and prioritize field characterization activities.

All SNL/NM facilities are situated on KAFB and adjacent Cibola National Forest lands withdrawn as part of an agreement between the DOE and the U.S. Forest Service. The SNL/KAFB area is located on a high, semiarid mesa and adjacent foothills, about $5 \mathrm{mi}(8.04$ $\mathrm{km}$ ) east of the Rio Grande. The mesa is cut by the east-west-trending Tijeras Arroyo, which drains into the Rio Grande. The eastern side of KAFB, north of Tijeras Arroyo, is bounded by the southern end of the Sandia Mountains, and, south of Tijeras Arroyo, by the northern end of the Manzano Mountains. Most of the area is relatively flat, sloping gently westward toward the Rio Grande. However, the eastern portions of KAFB and SNL/NM extend into the canyons of the northern Manzano (or Manzanita) Mountains. 


\section{EXECUTIVE SUMMARY}

(Continued)

Geologically, SNL/KAFB is located in the east-central Albuquerque Basin, a major structural feature of the Basin and Range Province. The site sits on a partially dissected bajada built by three alluvial fan systems: Tijeras Arroyo fan, Arroyo del Coyote fan, and the Travertine Hills Arroyo fan at the eastern margin of the Sandia-Manzanita mountains. The site straddles the major basin-bounding normal fault system (the Sandia and Hubbell Spring Faults), which trends north-south, as well as the Tijeras strike-slip fault, which cuts obliquely across the site along a northeast-southwest alignment. Because few deep boreholes have been drilled within the SNL/NM region, and because the distribution of subsurface geologic data is sparse, the subsurface hydrogeology of the SNL/KAFB site is, at present, poorly defined. The hydrogeologic framework across SNL/KAFB is defined by structural boundaries (e.g., the positions of major faults) and the spatial distribution of hydrostratigraphic units, lithotypes, and interlithotype heterogeneity.

The hydrogeologic setting includes the meteorological environment, surface water run-off, percolation through the vadose zone, and saturated groundwater flow. This report summarizes the current understanding of the occurrence. movement, and interaction of surface and subsurface water. Refining this understanding will help establish a quantitative basis for understanding the potential pathways for transport of contaminants from SNL/KAFB sites to receptors that could lead to adverse impacts to human health and safety.

The surface water system within the SNL/KAFB area consists primarily of ephemeral drainages. These drainages probably experience channel loss and thus contribute to groundwater recharge. Of additional concern is the possible erosion and subsequent surface transport and redistribution of contaminants.

The vadose zone provides the link between surface water hydrology (which deals with surficial processes such as precipitation, snow melt, run-off, infiltration, overland flow, and evapotranspiration) and groundwater hydrology concerned with the flow and transport processes in aquifer systems. The vadose zone is an important part of the hydrologic system in the SNL/KAFB area. In this semiarid climate, the vadose zone thickness is generally quite large [from 50 to $>500 \mathrm{ft}(15$ to $>150 \mathrm{~m})$ ]; consequently, most contaminants released near the ground surface must travel a long distance before reaching the water table. The majority of ER sites are located at or near the land surface. Contaminant concentrations that reach the water table are a concern with respect to the RCRA maximum contaminant limit (MCL). Dispersive effects in the vadose zone could dilute contaminant concentrations to the point that when and if contaminants reach the water table, concentrations might be less than the MCL. The regional areal recharge rate, which controls the upper boundary condition of the saturated zone, is also affected by vadose zone characteristics.

With respect to regional saturated zone hydrology, the basin-fill Santa Fe Group deposits are the primary aquifer in the Albuquerque Basin. The basin-fill aquifer consists of interbedded gravel, sand, silt, and clay and is part of a complex stream-aquifer system that has been extensively developed in parts of the basin for irrigation, domestic, and municipal water supply. Values of hydraulic conductivity range from 0.25 to $50 \mathrm{ft} /$ day $(0.08$ to $15 \mathrm{~m} /$ day $)$. 


\section{EXECUTIVE SUMMARY}

(Continued)

The aquifer properties have a considerable range of values because of the large variations in lithology of basin-fill deposits. Groundwater is generally assumed to be unconfined in the upper part of the aquifer. However, in the deeper parts of the aquifer, the water can be semiconfined or confined. The depth to groundwater is quite variable in the basin. $\mathrm{SNL} / \mathrm{KAFB}$ is situated in an area that includes two very different geologic environments separated by an assemblage of fault systems (see Section 3.2). This melange of geologic elements contributes to a complex saturated zone hydrogeologic framework. In Section 3.4.2, this framework is divided into three distinct hydrogeologic regions (HR), based on local geology. This hydrogeologic framework establishes the basis for the conceptual model (CM). This CM identifies four subareas within these three HRs defined by a mix of hydrologic characteristics that strongly impact the local saturated zone hydrology. Two of these subareas (subareas 1 and 2) are located in HR1 and are distinguished by the local transients caused by water-supply pumping wells. The other two subareas correspond to HR2 (subarea 3 ) and HR3 (subarea 4). Hydrologic characteristics considered in defining these subareas include differences in flow systems (porous media flow ard fracture flow), the type(s) of aquifers (unconfined/perched and confined), the state of the flow system (steadystate and transient), flow system boundaries, and flow system heterogeneities and anisotropies. Elements involved in future saturated zone characterization will include developing subarea flow models (planning and reporting), applying a quantitative approach to identify critical data gaps (numerical model application), and acquiring parameters to fill these gaps (drilling and testing). These elements taken together are intended to establish a strong, site-wide hydrogeologic understanding that will be used to support ER Program characterization and remediation projects.

With respect to saturated zone water chemistry, Riddle and Grant sampled groundwaters from water-supply wells and springs on the SNL/KAFB site. The wells sampled penetrate Santa Fe Group sediments. The springs were located in Tijeras Arroyo, the mouth of Coyote Canyon, and Hubbell Spring on the Isleta Pueblo Indian Reservation. In general, the wells and the springs in Tijeras Arroyo reflect water compositions derived from run-off from the Sandia and Manzanita Mountains, with calcium-bicarbonate-rich waters and lesser amounts of chloride, sulfate, and sodium. The water samples from Coyote Springs differ from samples obtained from other wells and springs in that they have significantly higher total dissolved solids and boron concentrations. Groundwater quality data indicate, among other things, that the groundwaters east and west of the Sandia/Hubbell Fault line are characterized by statistically different chemistries.

A site-wide, subsurface hydrogeologic CM is developed by constructing the hydrogeologic framework and evaluating the spatial distribution of geologic features that control hydrologic and contaminant transport parameters. This CM accounts for all relevant hydrogeologic processes, from surficial processes to vadose zone processes to saturated zone processes. This CM will be implemented, as required, by mathematical models that will permit us to make quantitative predictions regarding the behavior of the total hydrogeologic system, and it will be used to help guide site-specific field characterization activities. 


\section{EXECUTIVE SUMMARY}

(Concluded)

There are many aspects of the hydrogeologic system not fully understood; thus, our current conceptualization of flow and transport processes and our $\mathrm{CM}(\mathrm{s})$ are limited. Future characterization work will be planned and prioritized according to the methodology described in Section 2.0, which is driven by critical uncertainties and identified performance measures. The critical uncertainties are largely dictated by data needs for the ER Program operable units. This strategy will reflect close coordination with all ER Program task leaders. Once processes in need of characterization are identified, we will implement an iterative stochasticsimulation/field-characterization procedure to define particular field characterization activities and refine our understanding of the site-wide hydrogeologic system. 


\section{ACRONYMS}

\begin{tabular}{|c|c|}
\hline $\mathrm{CM}$ & Conceptual model \\
\hline $\mathrm{COE}$ & U.S. Arnı Corps of Engineers \\
\hline CSAMT & Controlled-source audio fre juency magnetotelluric \\
\hline CWL & Chemical Waste Landfill \\
\hline DNAPL & Dense nonaqueous-phase liquid \\
\hline DOE & U.S. Department of Energy \\
\hline $\mathrm{DOE} / \mathrm{AL}$ & U.S. Department of Energy, Albuquerque Operations \\
\hline $\mathrm{E} \& \mathrm{E}$ & Environment and Energy \\
\hline EPA & U.S. Environmental Protection Agency \\
\hline ER & Environmental restoration \\
\hline GPR & Ground-penetrating radar \\
\hline GWTT & Groundwater travel time \\
\hline $\mathrm{HR}$ & Hydrogeologic region \\
\hline HSWA & Hazardous and Solid Waste Amendments \\
\hline $\mathrm{HU}$ & Hydrogeologic unit \\
\hline IT & International Technology Corporation \\
\hline ITRI & Inhalation Toxicology Research Institute \\
\hline KAFB & Kirtland Air Force Base \\
\hline LSF & Lower Santa Fe \\
\hline LWDS & Liquid Waste Disposal System \\
\hline MCL & Maximum contaminant limit \\
\hline MSF & Middle Santa Fe \\
\hline MWL & Mixed Waste Landfill \\
\hline
\end{tabular}

NOAA National Oceanic Atmospheric Administration

PA Piedmont-slope alluvium

RA River alluvium

RCRA Resource Conservation and Recovery Act

RFI Resource Conservation and Recovery Act Facility Investigation

SFR South Fence Road

SNL Sandia National Laboratories

SNL/KAFB Sandia National Laboratories/Kirtland Air Force Base

SNL/NM Sandia National Laboratories, New Mexico

SWHC Site-Wide Hydrogeologic Characterization (Project) 
ACRONYMS

(Concluded)

$\begin{array}{ll}\text { TA } & \text { Technical Area } \\ \text { TSD } & \text { Transportation Safeguards Division } \\ & \\ \text { USDA } & \text { U.S. Department of Agriculture } \\ \text { USF } & \text { Upper Santa Fe } \\ \text { USFS } & \text { U.S. Forest Service } \\ \text { USGS } & \text { U.S. Geological Survey } \\ \text { VA } & \text { Valley-border alluvium } \\ \text { VOC } & \text { Volatile organic compound }\end{array}$




\subsection{INTRODUCTION}

The Sandia National Laboratories, New Mexico (SNL/NM), Site-Wide Hydrogeologic Characterization (SWHC) project has been implemented as part of the SNL/NM Environmental Restoration (ER) Program to develop the regional hydrogeologic framework and baseline for the approximately $100 \mathrm{mi}^{2}$ of Kirtland Air Force Base (KAFB) and adjacent withdrawn public lands upon which SNI 'NM has performed research and development activities. Additionally, the SWHC project will investigate and characterize generic hydrogeologic issues associated with the 172 ER sites ${ }^{1}$ owned by SNL/NM across its facilities on KAFB (McCord and Lauffer 1992). Examples of generic issues exist in all components of the hydrogeologic system, including surface water (e.g., erosion), the vadose zone (e.g., groundwater recharge), and the saturated zone (e.g., regional groundwater flow to receptors).

\subsection{Purpose}

As called for in the Hazardous and Solid Waste Amendments (HSWA) to the Resource Conservation and Recovery Act (RCRA) Part B permit agreement between the U.S. Environmental Protection Agency (EPA) as the permitter and the U.S. Department of Energy (DOE) and SNL/NM as the permittees (EPA 1993), an annual report is to be prepared by the SWHC project team. This document serves two primary purposes:

1. To identify and describe the conceptual framework for the hydrogeologic system underlying SNL/NM.

2. To describe characterization activities undertaken in the preceding year that add to our understanding (reduce our uncertainties) regarding the conceptual and quantitative hydrogeologic framework.

Because this project was not initiated until mid-1992 and because few hydrogeologic characterization activities were undertaken in 1992, this SWHC project annual report focuses primarily on purpose 1. Additionally, this first annual report is an appropriate vehicle for communicating the rationale we will employ to identify and prioritize field characterization activities. In future issues of the annual report, the conceptual framework and current understanding described in this issue will be updated and refined.

\subsection{Document Overview}

The remainder of this chapter provides an overview, including information regarding the general setting of the study area and of field activities undertaken in calendar year 1992 that contribute to our current understanding. Section 2.0 of the report describes the methodology

\footnotetext{
${ }^{1} \mathrm{SNL} / \mathrm{NM}$ is also responsible for more than thirty other ER sites that are located outside the SNL/KAFB area. One of the ER sites, the Chemical Waste Landfill located on $\mathrm{SNL} / \mathrm{KAFB}$, is not part of the HSWA Part B permit.
} 
that will be employed to identify issues and processes in need of characterization, and it also discusses the objective quantitative approach that will be used to prioritize and select among various possible characterization activities. Sections 3.1) and 4.0 describe the physical and chemical framework for the region with regard to geology and hydrology, respectively. Finally, Section 5.0 synthesizes the current state of knowledge into an overall hydrogeologic conceptual model (CM) for the region.

\subsection{General Setting}

As previously stated, the SWHC project focuses on investigating the hydrogeologic system underlying SNL/NM facilities. Figure 1-1 shows the study area's geographic location in the Rio Grande Valley on the southeast side of Albuquerque, New Mexico. As shown in Figures 1-2 and 1-3, all SNL/NM facilities are situated on KAFB and adjacent Cibola National Forest lands withdrawn as part of agreements between the U.S. Forest Service (USFS), KAFB, and the DOE. It is important to note that over most of this area DOE is a tenant of lands controlled by KAFB/USFS, that many U.S. Air Force facilities are interspersed with the DOE/SNL facilities, and that the relevant hydrogeologic system affecting and affected by SNL/NM extends beyond the political boundaries shown in Figures 1-2 and 1-3. Therefore, the region to be investigated, in coordination with the appropriate controlling organization, by this project will include all lands within the boundaries of KAFB and adjacent withdrawn buffer lands. We hereafter will refer to the study area as the Sandia National Laboratories/Kirtland Air Force Base (SNL/KAFB) tegion.

The SNL/KAFB region encompasses 52,223 acres $\left(211.4 \mathrm{~km}^{2}\right)$ and is bounded on the north and northwest by the City of Albuquerque, on the east by Cibola National Forest, on the south by the Isleta Pueblo Indian Reservation, and on the west by land owned by the State of New Mexico, KAFB (buffer zones), and the Albuquerque International Airport. Cibola National Forest is controlled by the USFS. There are two restricted access buffer zones on the southwest corner of the site that separate public access areas and the Isleta Pueblo Indian Reservation from KAFB and SNL/NM operations. Collectively, SNL/NM occupies 2,820 acres $\left(11.3 \mathrm{~km}^{2}\right)$ inside KAFB.

KAFB is located on a high, semiarid mesa and adjacent foothills, about $5 \mathrm{mi}(8.04 \mathrm{~km})$ east of the Rio Grande. The mesa is cut by the east-west-trending Tijeras Arroyo, which drains into the Rio Grande. The eastern side of the study area, north of Coyote Arroyo, is bounded by the southern end of the Sandia Mountains, and, south of Coyote Arroyo, by the northern end of the Manzano Mountains. Most of the area is relatively flat, sloping gently westward toward the Rio Grande. However, the eastern portions of KAFB and SNL/NM extend into the canyons of the northern Manzano (and Manzanita) Mountains. The western slope of the Manzanita Mountains facing KAFB is precipitous, rough, and has numerous arroyos.

Elevations range from $4,920 \mathrm{ft}(1,499.6 \mathrm{~m})$ at the Rio Grande to $7,988 \mathrm{ft}(2,434.7 \mathrm{~m})$ at the Manzano Lookout Tower in the Manzano Mountains. The mean elevation of SNL/KAFB is $5,348 \mathrm{ft}(1,630.1 \mathrm{~m})$.

\subsubsection{Land Use}

SNL/NM consists of five technical areas and several additional test areas. Each area has its own distinctive operations. SNL/NM facilities located on KAFB operate under a complex 


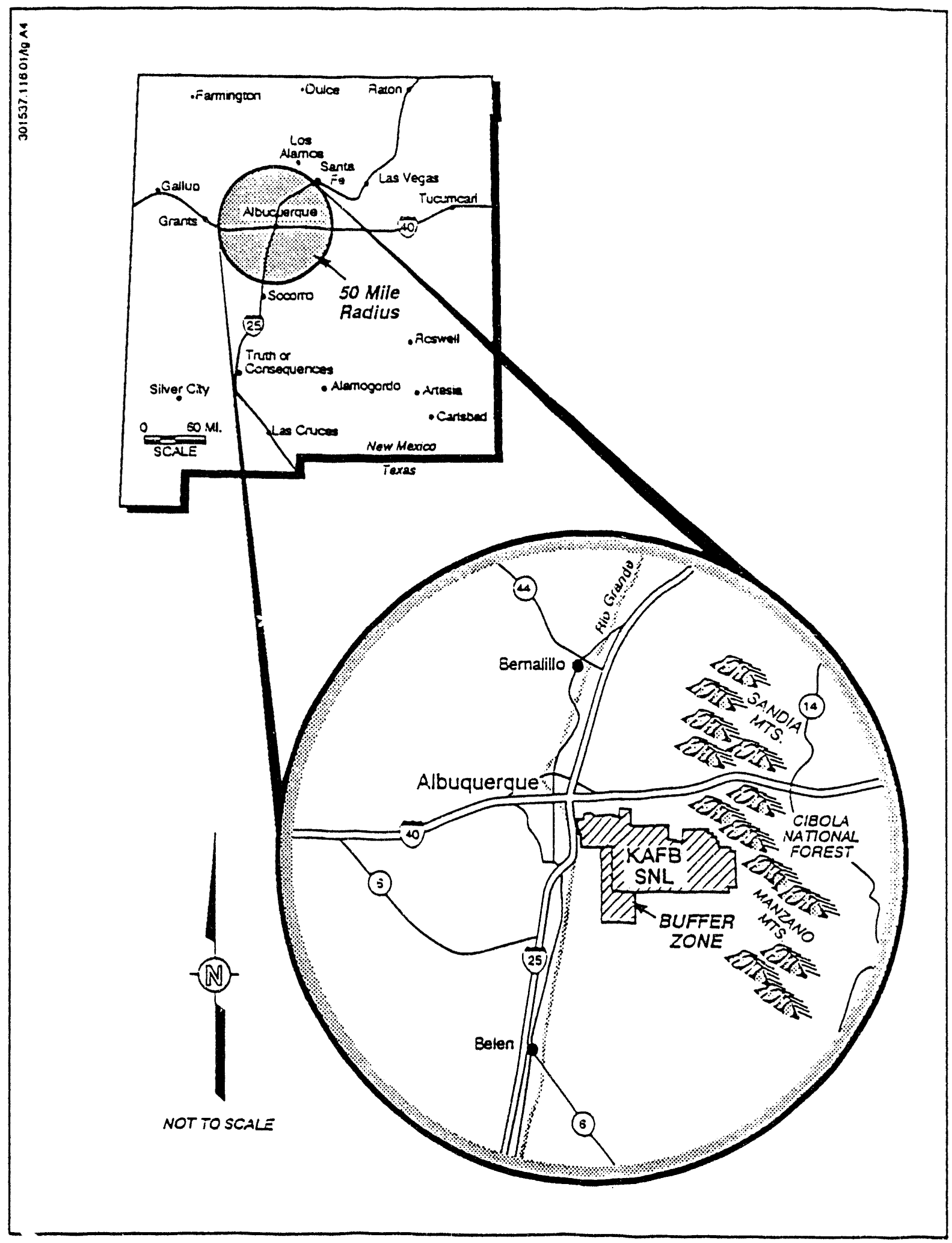

Figure 1-1. General Location Map of SNL/NM 


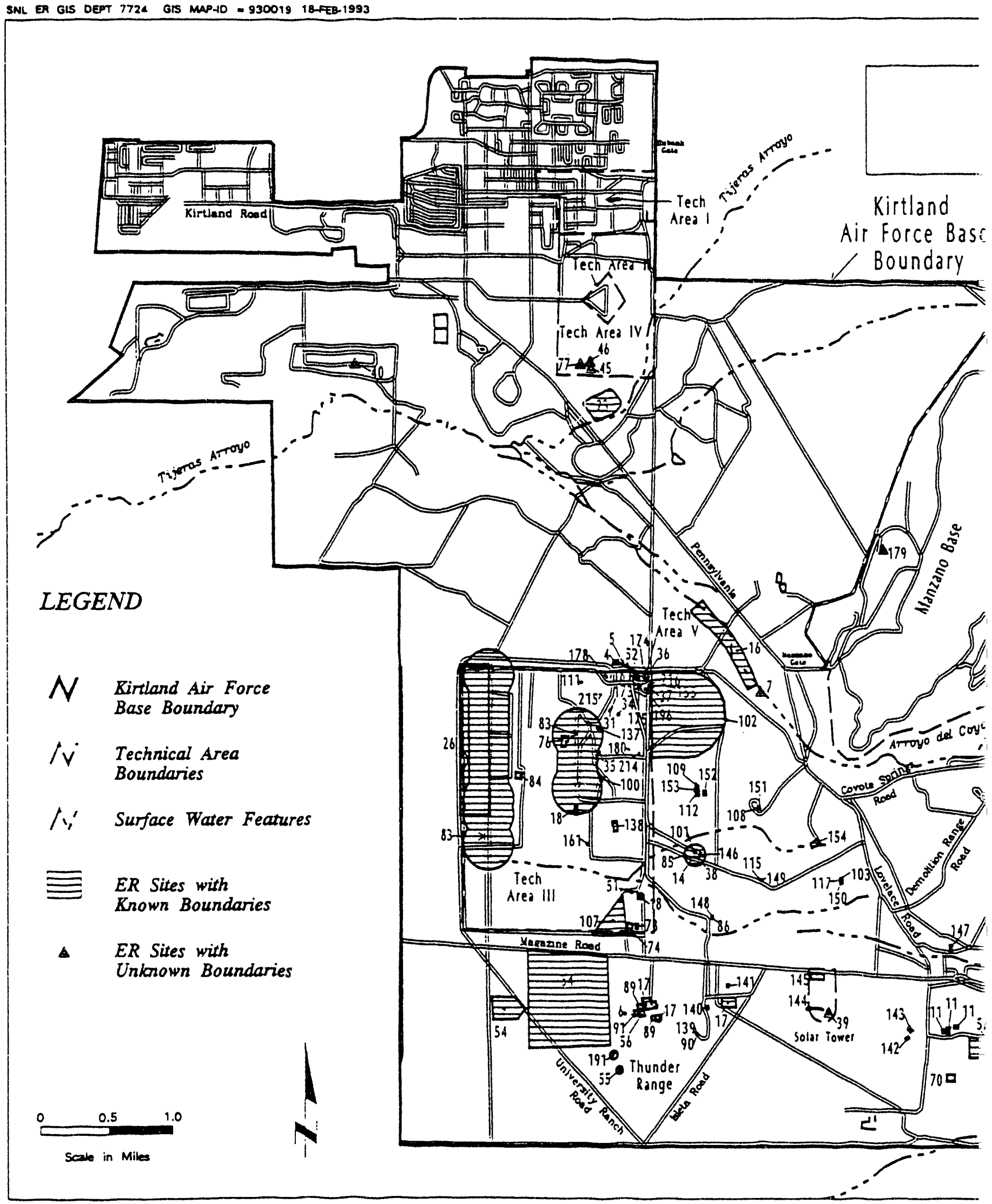

Figure 1-2. Location of 


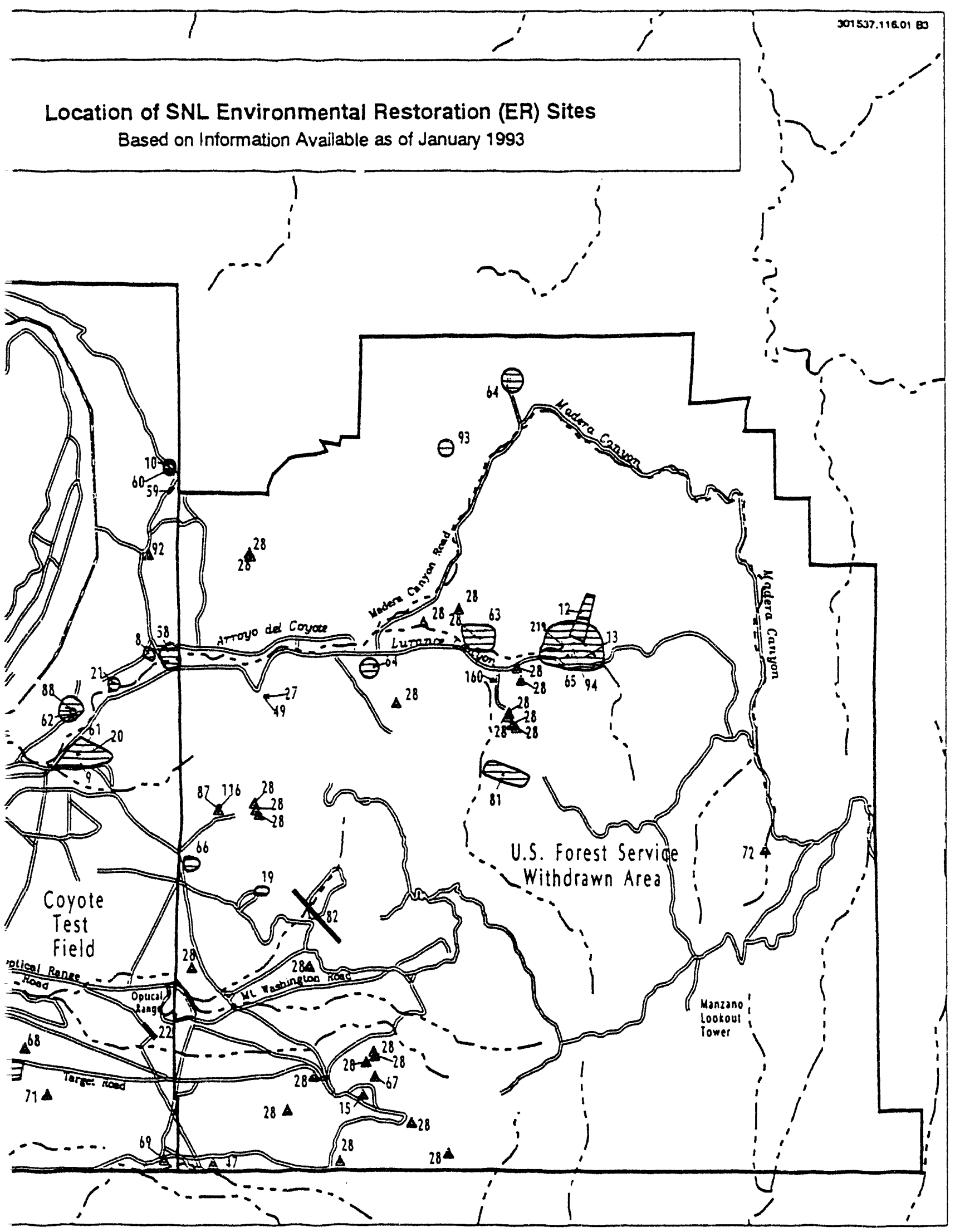

SNL/NM ER Sites 


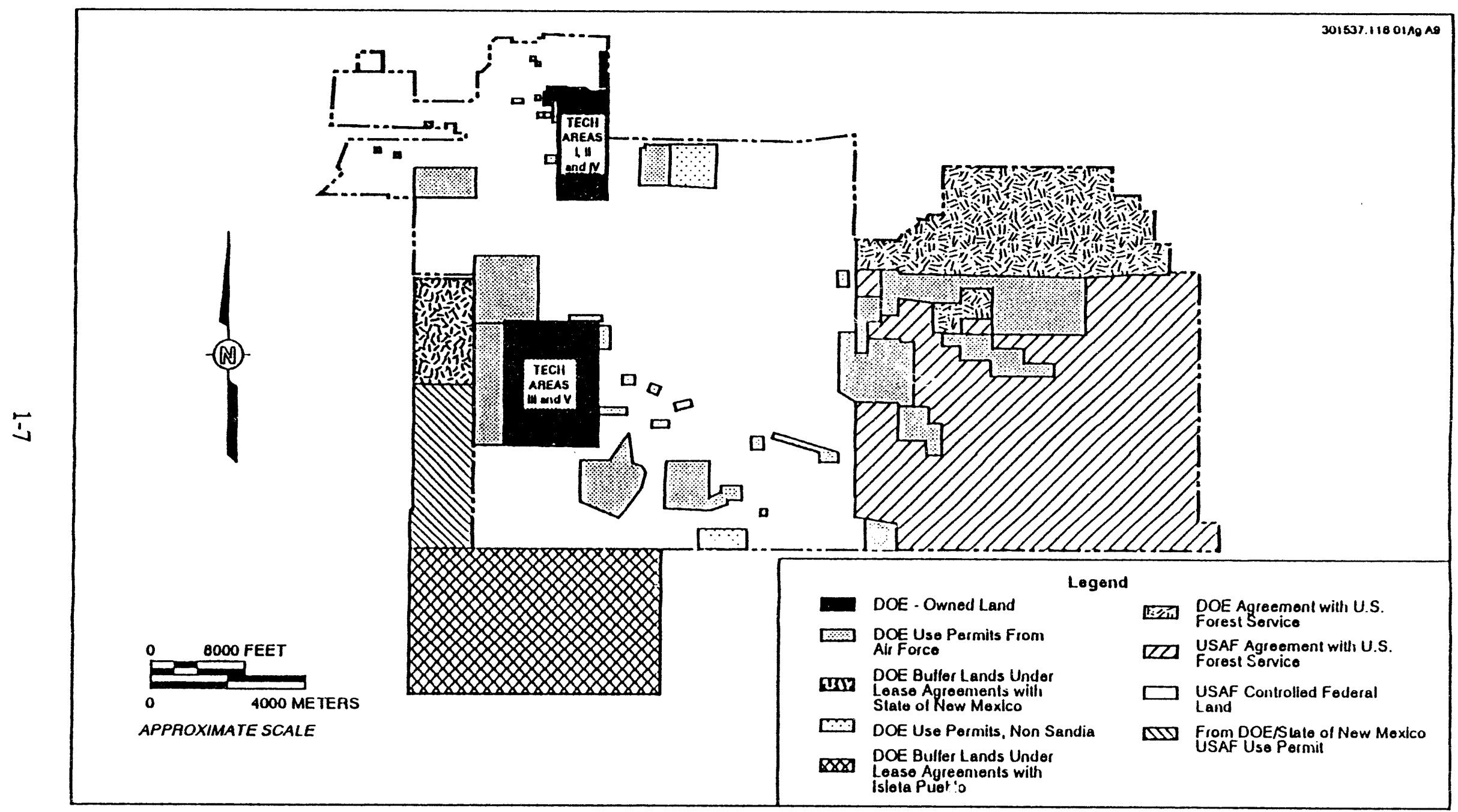

Figure 1-3. Land Ownership and Use Permits Within KAFB (including SNL) 
series of land-use agreements among the DOE Albuquerque Operations (DOE/AL), KAFB, and the USFS. An additional 14,920 acres $\left(60.3 \mathrm{~km}^{2}\right)$ are provided by land-use permits from KAFB, the USFS, the State of New Mexico, and the Isleta Pueblo Indian Reservation (SNL/NM 1992). Figure 1-3 shows the location of the land-use permits and technical areas.

SNL/NM has additional test areas outside the five technical areas. These areas are located south of Technical Area (TA) III and in the canyons on the west side of the Manzano Mountains. Thunder Range and Coyote Canyon Test Field are such areas.

\subsubsection{Demographics}

The largest and closest population center to KAFB is the City of Albuquerque, which bounds KAFB on the north and northwest. The 1990 census lists the population of the City of Albuquerque as 384,734 and the population of Bernalillo County as 480,577 , which includes permanent residents of KAFB living on base in KAFB housing areas. Isleta Pueblo, south of KAFB, is the next-nearest population center, with a 1993 population of 4,538 .

\subsubsection{History and Mission}

SNL/NM was established in 1945 and was operated by the University of California until 1949, when President Truman asked American Telephone and Telegraph to assume the operation as an "opportunity to render an exceptional service in the national interest" (SNL/NM 1991).

Designated by Congress as a national laboratory in 1979, SNL/NM is one of the DOE's most diverse laboratories and one of the nation's largest research and development facilities. SNL/NM's main responsibility is national security programs in defense and energy, with primary emphasis on nuclear weapons research and development. SNL/NM also does work for the Department of Defense and other federal agencies on a noninterference basis.

Current activities at SNL/NM include process development, environmental testing, radiation research, combustion research, computing, and microelectronics research and development. Over SNL/NM's four decades of existence, its mission has changed. From an original focus on nuclear weapons research and development, its activities have expanded to include research on other advanced military technologies, energy programs, arms verification, control technology, and applied research in numerous scientific fields, including an extensive program in materials research. Energy efforts include combustion research, integrated geosciences research, and solar and wind power programs. SNL/NM environmental projects include programs in waste reduction and research for environmentally conscious manufacturing and environmental restoration.

\subsection{Calendar Year 1992 Characterization Activities Relevant to SNL/KAFB}

During the current reporting period, a number of characterization activities were undertaken within the SNL/KAFB region that contribute to the current understanding. One of these activities was designed solely to increase our understanding of the regional hydrogeologic system; the others are related to contamination characterization studies for particular ER 
sites. Shaded areas in Figure 1-4 depict the location of each of these characterization efforts, and the following paragraphs summarize the work performed at these sites. Information derived from these efforts is discussed in appropriate subsections of Sections 3.0 and 4.0. Table 1-1 shows the general type of data obtained from each of these studies.

Table $1-1$

Calendar Year 1992 Field Activities That Provided Data to the SWHC Project

\begin{tabular}{|c|c|c|c|c|c|}
\hline \multirow{2}{*}{$\begin{array}{l}\text { PROJECT } \\
\text { ID }\end{array}$} & \multirow{2}{*}{$\begin{array}{l}\text { TYPE OF } \\
\text { ACTIVITY }\end{array}$} & \multicolumn{4}{|c|}{ TYPE OF DATA COLLECTED } \\
\hline & & LITHOLOGIC & GEOPHYSICAL & HYDROLOGIC & GEOCHEMICAL \\
\hline $\begin{array}{l}\text { South Fence } \\
\text { Road Wells }\end{array}$ & Hydrologic & $\checkmark$ & $\checkmark$ & $\checkmark$ & \\
\hline $\begin{array}{l}\text { Chemical } \\
\text { Waste Landfill }\end{array}$ & Contam. Char. & $\checkmark$ & & $\sqrt{ }$ & $\checkmark$ \\
\hline $\begin{array}{l}\text { Mixed Waste } \\
\text { Landfill }\end{array}$ & Contam. Char. & $\checkmark$ & $\checkmark$ & $d$ & 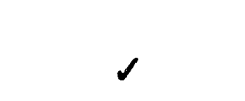 \\
\hline TA-V LWDS & Contam. Char. & $\checkmark$ & $\sqrt{2}$ & $d$ & $\checkmark$ \\
\hline $\begin{array}{l}\text { TA-II ER } \\
\text { Project }\end{array}$ & Contam. Char. & 2 & $\sqrt{2}$ & $\checkmark$ & $\checkmark$ \\
\hline $\begin{array}{l}\text { Sanitary Sewer } \\
\text { Line Trench }\end{array}$ & $\begin{array}{l}\text { Geologic } \\
\text { Mapping }\end{array}$ & $\checkmark$ & & $\checkmark$ & \\
\hline $\begin{array}{l}\text { Travertine } \\
\text { Hills }\end{array}$ & $\begin{array}{l}\text { Geologic } \\
\text { Mapping }\end{array}$ & $\checkmark$ & & & \\
\hline
\end{tabular}

\subsubsection{South Fence Road Hydrogeologic Wells}

Given the limited amount of data available near the south boundary of KAFB straddling the basin-bounding normal fault system (see Sections 3.2 and 4.4.2), a gravity geophysical survey was performed and a series of hydrogeologic characterization wells installed along South Fence Road (SFR) adjacent to the Isleta Pueblo Indian Reservation (see Figure 1-4). The gravity survey was intended to provide an estimate of depth to Paleozoic bedrock and thus help locate the buried fault system (see Sections 3.5 and 3.6). On the basis of the interpreted bedrock depths, four boreholes were advanced at four different locations. Two of the boreholes were completed with well screens at two different depth intervals to ascertain vertical hydraulic gradients in the uppermost aquifer(s). One of the boreholes was completed in a single permeable zone; the fourth remains uncompleted. Section 4.4 contains a summary discussion of the data and interpretations. Neel and McCord (1993) is a detailed report of the field activities and data collected as part of this drilling program. 


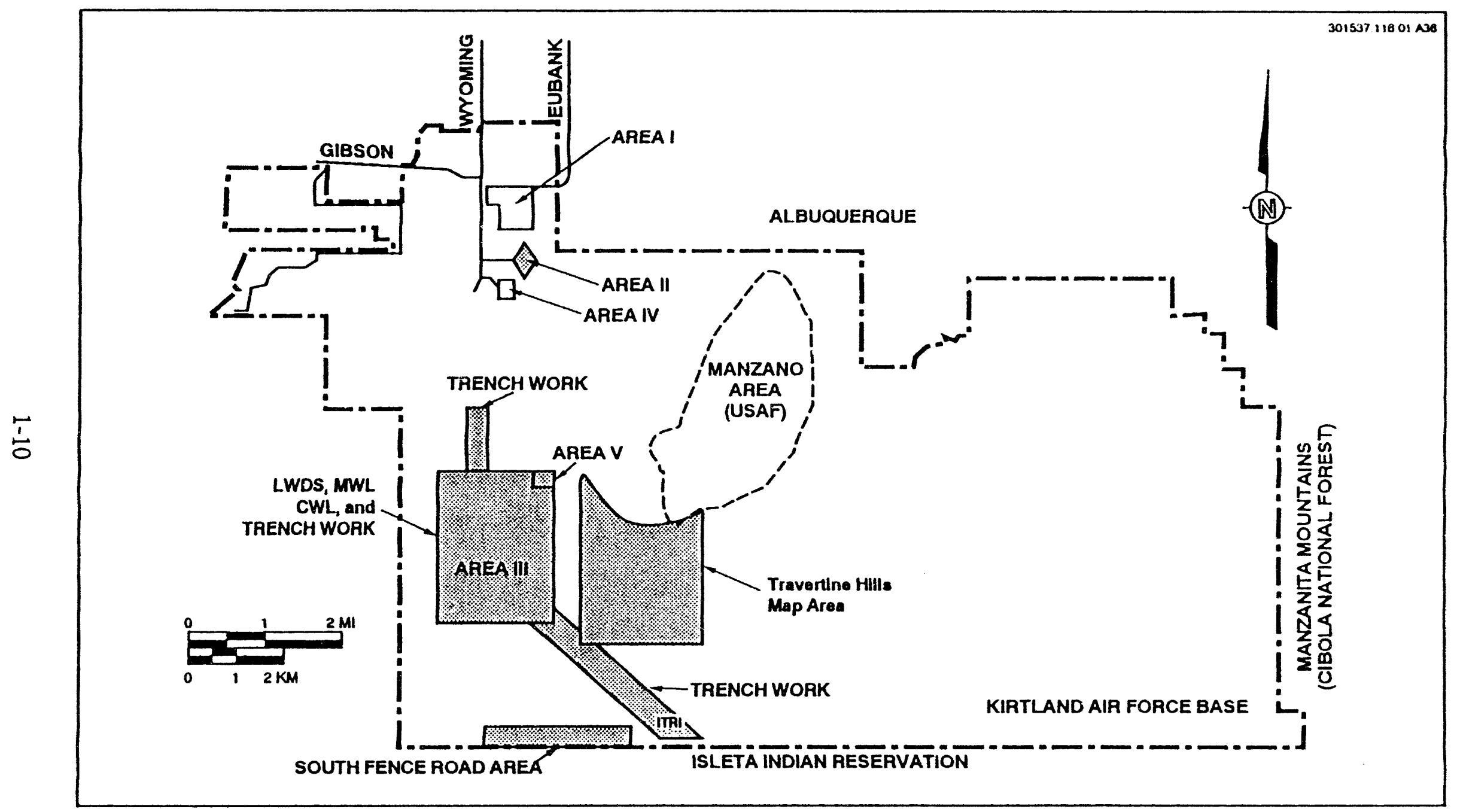

Figure 1-4. Locations of 1992 RER Site Activities That Contributed to the SWIIC 


\subsubsection{Contaminant Characterization Activities at the SNL/NM Chemical Waste Landfill}

Work performed at the Chemical Waste Landfill (CWL) for calendar year 1992 consisted of characterization of a volatile organic compound (VOC) contaminant plume in the vadose zone. These activities began in November of 1992 and have continued into calendar year 1993. Soil and soil gas samples were taken from depths of up to $275 \mathrm{ft}(83.8 \mathrm{~m})$ in the vicinity of the landfill. Although data collection efforts focused on contaminant characterization, some samples were analyzed for in situ moisture content. Laboratory analyses had not been completed by the end of 1992 .

\subsubsection{Contaminant Characterization Activities at the SNL/NM Mixed Waste Landfill}

Work performed at the Mixed Waste Landfill (MWL) for calendar year 1992 included an infrared thermographic surface geophysical survey to aid in lucating buried wastes and moisture content anomalies. This information was used to aid in siting an angled monitoring well, which was begun in the final working days of calendar year 1992. This well, known as MWL-MW4, is to be drilled approximately 6.75 degrees from vertical and is designed to be completed beneath a trench suspected of receiving tritiated water discharges. Continuous core is being collected using the sonic drilling technique, with lithologic and borehole geophysical logging to be performed by U.S. Geological Survey (USGS) personnel. Intentions are to complete the well in two zones to assess vertical gradients and hydraulic conductivity anisotropy in the aquifer beneath the MWL.

\subsubsection{Contaminant Characterization Wells at the Technical Area V Liquid Waste Disposal System}

Work performed at the TA-V Liquid Waste Disposal System (LWDS) for calendar year 1992 included the installation of eight (8) contaminant characterization boreholes and one (1) monitoring well. The sonic technique was used to drill all of the holes. Five (5) of the boreholes were advanced to a total depth of $100 \mathrm{ft}(30.5 \mathrm{~m})$ around the perimeter of the LWDS surface impoundment, and three (3) were angle-drilled to a depth of $50 \mathrm{ft}(15.2 \mathrm{~m})$. Continuous core was taken from all of the boreholes, and lithologic logging was performed by USGS personnel. The monitoring well was advanced to a depth of $525 \mathrm{ft}(160.0 \mathrm{~m})$, intersecting the water table at a depth of about $510 \mathrm{ft}(155.4 \mathrm{~m})$. Core was collected during drilling of the monitoring well, with lithologic and borehole geophysical logging performed by USGS personnel.

\subsubsection{Contaminant Characterization Well at Technical Area II}

Work performed at TA-II consisted of the installation of a single borehole advanced to a depth of $330 \mathrm{ft}(100.6 \mathrm{~m})$; the borehole was located just outside the TA-II fence (Figure 1-4). Samples were collected at regular intervals for contaminant characterization and for determination of in situ moisture content, cation exchange capacity, and percent organic carbon. Lithologic and borehole geophysical logging were performed by USGS personnel. Water was encountered at $309 \mathrm{ft}(94.2 \mathrm{~m})$, and a monitoring well was completed at this depth. The completion interval is presumed to be in a perched zone. 


\subsubsection{Geologic Mapping of the Sanitary Sewer Line Trench}

During 1990 through 1991, a sewer line extension was constructed from just south of Tijeras Arroyo south and eastward to the Inhalation Toxicology Research Institute (ITRI) facility (see Figure 1-4 for approximate alignment). During excavation, the ER Program mapped the geologic materials exposed in trench walls. A report was issued in calendar year 1992 (IT 1992) that describes geologic conditions encountered. Along its entire $30,000+\mathrm{ft}(9,146-\mathrm{m})$ length (including laterals), the 3- to 18-ft deep trench exposed alluvial fan deposits. In the last quarter of 1992, a geostatistical analysis of trench map data was initiated (McCord et al. 1993) to quantify the spatial correlation characteristics of alluvial fan materials.

\subsubsection{Geologic Mapping of the Travertine Hills}

The Travertine Hills, located on the eastern portion of KAFB (Figure 1-4), represent the furthest western outcropping of Precambrian and Paleozoic rocks in this part of the Albuquerque Basin. As part of an effort to develop a site-wide surface geologic base map, Krumhansl and McConnel (in preparation) performed a detailed geologic mapping of the Travertine Hills region. Section 3.5 provides a summary of the results of that study.

\subsection{References}

EPA (U.S. Environmental Protection Agency), 1993. Hazardous Waste Permit to SNL and USDOE, Module IV, Special Conditions Pursuant to the 1984 HSWA to RCRA for SNL/NM, EPA I.D. NM5890110518.

IT (International Technology Corporation), 1992. Geologic Mappinis of the Sanitary Sewer Line Excavation, Southern Sandia National Laboratories, Albuquerque, NM, Contractor Report to SNL/NM ER Program, SWHC/4.0001, Sandia National Laboratories, Albuquerque, NM.

Krumhansl, J. L. and V. S. McConnel, in preparation. Geology of the Central Kirtland Air Force Base and the Travertine Hills, SAND93-0683, Sandia National Laboratories, Albuquerque, NM.

McCord, J. T., and F. C. Lauffer, 1992. Project Plan and Functional Organization for the Site-Wide Hydrogeologic Characterization Project, SNL/NM ER Program Internal Report SWHC/1.0001, Sandia National Laboratories, Albuquerque, NM.

McCord, J. T., D. Crowson, R. Holt, J. Piper, and E. K. Webb, 1993. Detailed Mapping and Preliminary Geostatistical Analysis of Alluvial fan Deposits Exposed in Six Miles of Trench, SAND93-0680, in preparation, Sandia National Laboratories, Albuquerque, NM.

Neel, D., and J. P. McCord, 1993. Summary of Phase I Field Operations, South Fence Hydrogeologic Wells, SAND93-7038, in preparation, Sandia National Laboratories, NM. 
SNL/NM (Sandia National Laboratories, New Mexico), 1991. Pre-Tiger Team Self-

Assessment Report, SAND90-2827, Sandia National Laboratories, Albuquerque, NM.

SNL/NM (Sandia National Laboratories, New Mexico), 1992. Sandia National Laboratories, Albuquerque, Environmental Baseline Update, prepared by IT Corp. and Consensus Planning, Project Number 301182.56.01, Sandia National Laboratories, Albuquerque, NM. 


\subsection{QUANTITATIVE APPROACH TO SITE CHARACTERIZATION}

As discussed in Section 1.0, the SWHC project has been tasked with providing the baseline hydrogeologic framework for the SNL/KAFB region. A major component of that effort will be developing a database on the hydrogeologic flow and transport characteristics of the vadose zone and aquifer(s) underlying the site. This database will include detailed geologic and hydrostratigraphic maps, surface and borehole geophysical data and interpretations, and well drilling and testing data.

Typically, large-scale (and even small-scale) hydrogeologic studies are undertaken with expert judgment providing the basis for the data collection plan (DOE 1988, Russell 1990). Unfortunately, such an expert-opinion-based approach can lead to ambitious characterization programs that often collect more data than is required to meet project objectives. These also tend to be open-ended characterization programs that do not clearly define a stopping criteria to the data collection effort. In summary, they can lead to a potentially endless effort in which the site is "characterized to death." An objective approach to the site characterization problem is needed due to the large size of the region, the highly complex geologic setting, and the limited resources available to direct toward this problem. An objective approach will be implemented on this project to avoid the overcharacterization syndrome.

An alternative is to clearly and quantitatively define site performance measure(s) and acceptance criteria at the outset of a characterization project. The performance measures and acceptance criteria mus: be closely linked to the regulatory requirements associated with specific ER sites. The characterization effort will subsequently focus on collecting data that most strongly influence the performance measure. Once the performance measure can be demonstrated to meet the acceptance criteria within an acceptable level of uncertainty, data collection can stop. An example performance measure would be the groundwater travel time (GWTT) from a source to a receptor, and a related example acceptance criteria would be that the travel timie must exceed 100 yrs, with a 95-percent confidence. Data that affect our understanding of the travel time include the gradient, the hydraulic conductivity distribution, and the media porosity. In this example, we would collect relevant data at the site to help estimate the GWTT with a 95-percent confidence interval. If the 95-percent travel time is less than 100 yrs, the site passes and we are done with our job; if the 95-percent travel time exceeds 100 yrs, the site fails and site stabilization or alternative corrective measures are implemented. The methodology adopted here follows the spirit of the cost-benefit objectivefunction approach for assessing data worth advocated by Freeze et al. $(1987,1992)$, and the performance-assessment/site-characterization approach favored by Conrad and Dickman (1992).

This chapter summarizes the quantitative approach to be used for (1) identifying flow and transport processes in need of characterization, and (2) identifying and prioritizing data collection activities in the SWHC project. Following a brief review of other studies that have looked at this problem is a discussion of details of the SWHC project and the SNL/NM ER Program relevant to defining potential performance measures and acceptance criteria. We then outline a stepwise procedure we will employ to identify the significant hydrologic 
transport processes in need of characterization. Finally, the iterative performance-measure computation/decision analysis/data collection approach that constitutes our methodology is described.

\subsection{Background and Previous Studies}

As implied in the introduction, a goal of any site characterization effort is to reduce uncertainty in the ability to predict relevant aspects of site performance (e.g., predicting the GWTT to a 95-percent confidence interval). Studies by Loaiciga (1989) and Carrera c: al. (1990) describe optimization approaches toward designing monitoring/characterization well networks. These papers focus on using prior measurements of groundwater levels and hydraulic conductivity in conjunction with inverse simulation to identify optimal locations for additional monitoring wells to reduce overall hydraulic head, conductivity, and/or concentration uncertainty. In general, their approaches tend to be restricted to aquifers with rather limited, zoned heterogeneity due to the use of inverse models. If one is interested in defining the tails of a distribution (such as fast groundwater travel paths), simplistic descriptions of heterogeneity might be inadequate. The approaches advocated by Freeze et al. (1987, 1992) and Conrad and Dickman (1992) offer alternative means for identifying site characterization activities and easily incorporate consideration of highly complex spatial variability in aquifer properties.

Conrad and Dickman (1992) emphasize the need for tying predictive models to regulatory performance criteria and using models commensurate with available data. They recommend using Monte Carlo analysis tied to sensitivity studies to identify/prioritize parameters in site characterization programs. Freeze et al. (1992) emphasize approaches for dealing with hydrogeologic parameter uncertainty in conjunction with spatial variability. Spatial variability of aquifers and methods for treating this variability have been the subjeci of numerous academic research studies in the last fifteen years, but application of these concepts to actual field problems has been somewhat limited (Peck et al. 1988). To deal with spatial variability in site characterization, Freeze et al. (1992) advocate use of Bayesian probability analysis in conjunction with Monte Carlo simulation of flow and transport in heterogeneous aquifers.

The approach advocated by Freeze et al. $(1987,1992)$ is based on the premise that hydrogeologic data have worth only if they aid in making decisions between alternate courses of action. Freeze et al. (1992) use as an example the decision as to whether or not a landfill needs a liner. For this problem, the hydrogeologic site characterization effort focuses on collecting data that can help in making this decision; that is, data that can help quantify the performance of the landfill with and without a liner. A similarity to the thesis of Conrad and Dickman (1992) is noted, which recommends collecting only data that can be used to quantify site performance with regard to clearly defined performance criteria (regulatory criteria in Conrad and Dickman). To objectively and quantitatively implement their strategy, Freeze et al. (1992) employ a cost-benefit objective function. For each characterization option $i$, one can compute an objective function, $\phi_{i}$ : 


$$
\phi_{i}=\mathrm{B}_{i}-\mathrm{C}_{i}-\mathrm{R}_{i},
$$

where $\mathrm{B}_{i}$ are the benefits, $\mathrm{C}_{i}$ are the costs, and $\mathrm{R}_{i}$ are the risks. All of these quantities are weighed in a common monetary unit (e.g., dollars). The risk can equal the probability of failure, $\mathrm{P}_{f}$, multiplied by the costs of failure, $\mathrm{R}_{i}=\mathrm{P}_{f, i} \mathrm{C}_{f}$; thus, Equation 2.1 can be rewritten:

$$
\phi_{i}=\mathrm{B}_{i}-\mathrm{C}_{i}-\mathrm{P}_{f, i} \mathrm{C}_{f}
$$

Note that parameter spatial variability/uncertainty comes into the equations through the risk term, specifically through $\mathrm{P}_{f}$. Presumably, all of the other inputs to the objective function (the costs and benefits) are easily defined. The challenge becomes quantifying $\mathrm{P}_{f}$; once it is quantified, the objective function can be tabulated (Equation 2.2) for each option and the option that maximizes benefits can be implemented. In this study, site-specific factors related to the ER Program Operable Units (e.g., depth to the water table, contaminants of concern) will be used to help define the objective function. Section 2.4 describes how stochastic groundwater flow simulation can be used to assess $\mathrm{P}_{f}$.

\subsection{The SNL/NM ER Program, the SWHC Project, and Some Potential Performance Criteria}

Although the studies previously described certainly offer useful strategies that can be employed in the SWHC project, some aspects need some refining to make them relevant, others might be inappropriate for the SWHC, and still others might need to be developed for this particular problem. This section describes the SWHC and its role in SNL/NM's ER Program and how this might suggest some potential performance criteria and thus affect sitewide hydrogeologic characterization strategy.

As stated previously, SNL/NM is responsible for 172 ER sites within the SNL/KAFB region (see Figure 1-2). Almost all of these sites are the result of surficial or near-surface [depths $<15 \mathrm{ft}(4.6 \mathrm{~m})]$ contamination resulting from operations. Some of the sites are landfills, some are septic tank drainfields, some are from localized surface spills, and some are scattered debris resulting from firing range tests. Over most of the region, the depth to groundwater is over $50 \mathrm{ft}(15.2 \mathrm{~m})$ and is in excess of $400 \mathrm{ft}(122 \mathrm{~m})$ for all sites west of the basin-bounding fault systems (see Section 4.4).

SNL/NM will assess each of its ER sites through the RCRA Corrective Action process outlined in its HSWA permit from the EPA. An important goal of the ER site assessments is determining risks posed, so that a decision can be made as to whether or not to remediate a site. Although site-specific RCRA Facility Investigation (RFI) studies will provide much of the data required to quantify these risks, there are numerous generic hydrologic flow and transport issues that can be investigated by a single project (e.g., SWHC) to develop answers that can be used by many projects (e.g., the ER site RFIs). Obviously, the fate and transport 
of contaminants through the vadose and saturated zones strongly influence the ultimate risk posed by a site. To arrive at a risk value, the EPA requires the likely concentration of a contaminant at a receptor to be assessed. Furthermore, SNL/NM must install groundwater monitoring networks around all sites with a potential groundwater contamination problem, yet almost all of the sites currently have no nearby wells (thus, the site-specific hydraulic gradients required to design monitoring well networks are highly uncertain). Finally, because most of the potential receptor wells are located a significant distance from the potential contaminant sources (much more than $1 \mathrm{mi}$ for roughly 80 percent of the ER sites), high-conductivity channels that can lead to greatly reduced travel times to the receptors are of great concern.

Contaminant transport to and through the groundwater system, the hydraulic gradient around ER sites, and GWTTs (through the vadose zone and from beneath a site to a receptor well) are three important hydrogeologic issues that can be directly related to a regulatory assessment of risks posed by the ER sites. Quantitative performance measures can be drawn from this list of issues. In the SWHC we will use the performance measures in two ways: (1) to help identify important "processes" in need of investigation and characterization, and (2) to help identify and select among various characterization activities. The distinct natures of these two activities are clarified in the next two sections.

\subsection{High-Level Identification of Significant Processes}

Site characterization efforts typically begin with an assessment of existing knowledge about the site, identification of gaps in existing data, and implementation of characterization activities designed to fill data gaps. Professional expertise (in the form of unsubstantiated though professional opinion) is relied upon to identify processes requiring characterization. Although this may lead to a reasonable characterization program, it may also result in the neglect of potentially important processes. For example, volatile contaminants in the vadose zone are strongly affected by gas-phase transport processes and less so by aqueous-phase transport.

In an effort to avoid the pitfall of overlooking important processes, the SWHC plans to employ the following procedure to identify significant processes in need of characterization. This procedure will be applied to surface water, vadose zone, and saturated zone characterization.

To develop the understanding required for characterization of significant flow and transport processes and subsequent analysis, the SWHC will first do the following:

1. Define quantitative measures to be used in evaluating the significance of processes and develop a high-level quantitative approach for work prioritization.

2. Identify and itemize all processes by which contaminants could be transported from a source to a receptor.

3. Evaluate the current understanding of each process through a review of the literature and discussions with experts in the field. 
4. Determine the possible "significance" of each process with respect to the ER sites using the chosen quantitative measures and choose/develop/update our CM for the process. Site-specific information and scoping/conservative calculations can be employed to cull the original list of processes.

5. Define work required to reduce uncertainty with respect to operable processes and our CMs for the processes. In this step, one would (1) evaluate those processes whose significance cannot be adequately determined, and (2) refine the understanding of processes we know to be significant.

6. Prioritize work with respect to the chosen quantitative measures related to uncertainties at ER Operable Units and available funding (cost-benefit analysis) and refine/apply a quantitative approach for prioritization.

7. Proceed with work to reduce uncertainty with respect to operable processes and develop the required scientific understanding of "significant" processes through conceptual and mathematical modeling and controlled experimentation at both the laboratory and field scales.

This process is schematically illustrated in Figure 2-1. After a particular process has been determined significant, one must then characterize the hydrogeologic system with respect to the particular process. The next section describes the quantitative approach that will be employed to identify and select among the various characterization activities.

\subsection{Quantitative Approach to Identification and Selection of Characterization Activities}

Based on the information presented in Sections 2.1 and 2.2 describing alternative approaches to site investigation and identifying useful performance measures for the SWHC project, a hybrid quantitative methodology is most suited to meet SWHC needs. In essence, the steps to this methodology are (1) definition of performance criteria and objective function; (2) literature review, development of baseline hydrogeologic understanding, and reconnaissance for identification of typical hydrogeologic settings on SNL/KAFB; and (3) implementation of an iterative stochastic analysis and characterization (data collection) process. Step 1 will tier off the discussion contained in Section 2.2 on performance measures. Although the discussion in Section 2.2 identifies qualitative performance measures, it does not quantify them, nor does it identify an objective function that can be used to select among competing characterization options. The report by McCord et al. (1993) provides detailed discussion concerning this issue.

Step 2 is largely qualitative in nature and is typically used in many large-scale hydrogeologic characterization efforts. In preparing this first annual report for the SWHC project, th literature review and the development of a baseline understanding have essentially been completed. Part of Step 2 is also the identification of prototypical hydrogeologic settings on SNL/KAFB. At this point, let it suffice to say that there are four distinct saturated zone subareas on SNL/KAFB and probably more vadose zone settings. As the SWHC field activities move forward, an appropriate level of characterization should occur within each the prototypical settings. 


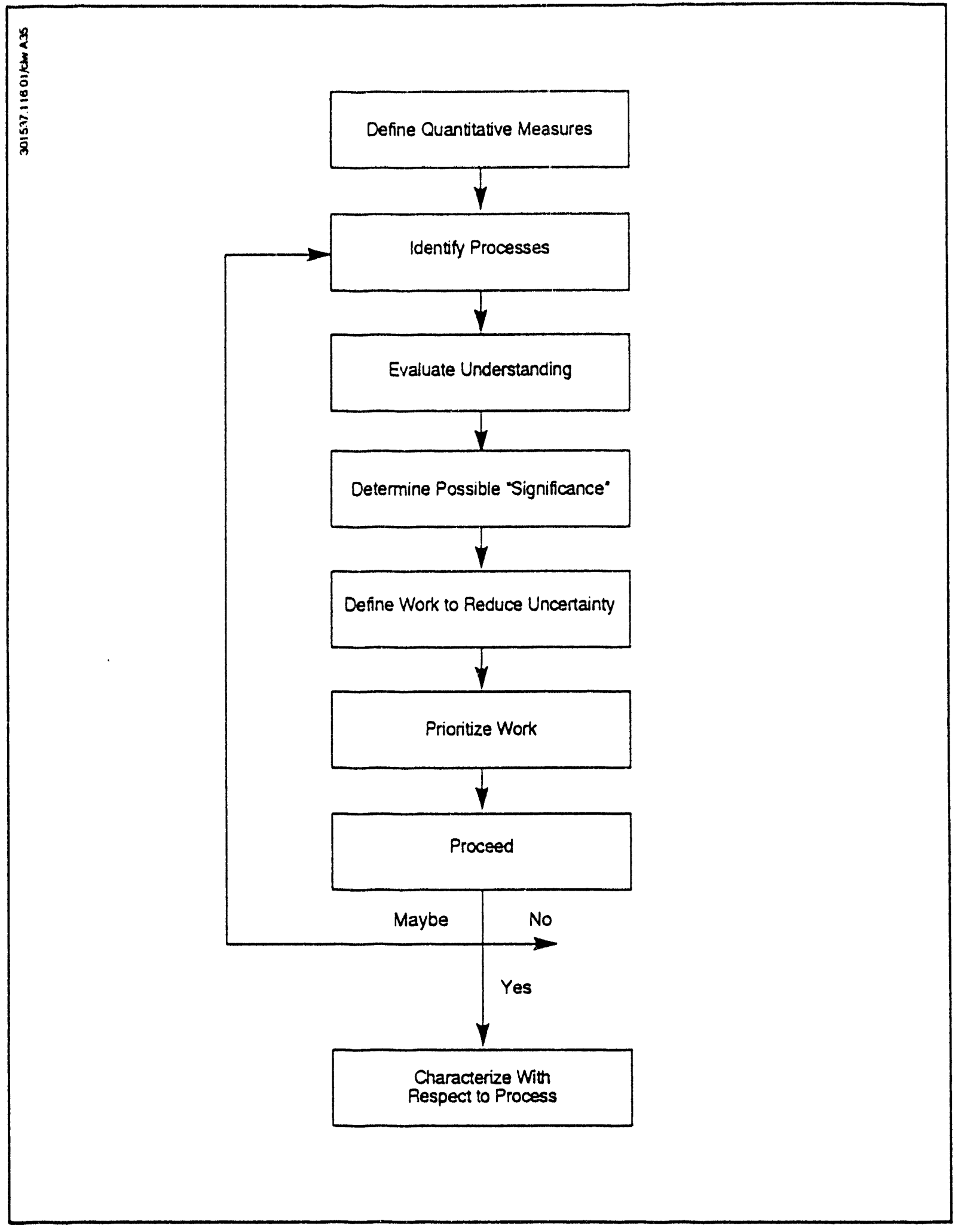

Figure 2-1. Flow Chart for Identification of Processes Requiring Characterization 
Step 3 represents the more quantitative, objective parts of the methodology. It borrows much from the objective function approach of Freeze et al. (1992) and the performance assessment approach of Conrad and Dickman (1992). The iterative process is based on the assumption that performing quantitative analyses using all currently available data can yield information/insights regarding hydrogeologic behavior of a site and can alert us to "holes" in our understanding of that behavior. It is hoped that this information will help us "characterize smarter." The iterative process consists of five well-defined steps: (1) generation of multirealization simulation results using a numerical implementation of our CM of groundwater flow at SNL/NM; (2) using the simulation results and sensitivity studies to define a set of possible characterization activities ( $\mathrm{P}_{f}$ from Equation 2.2 would be computed at this step); (3) using an objective function approach (see Equations 2.1 and 2.2) with Bayesian updating for selecting one or two activities (those activities that maximize the uncertainty reduction at the ER Operable Units) from the set developed in Step 2; and (4) implementing the field characterization activities selected in Step 3. The final step (5) consists of repeating Steps 1 through 4 with updated data as necessary.

Figure 2-2 outlines the iterative framework to be employed in the iterative process. For detailed discussions on each step in the methodology, see the report by McCord et al. (1993).

\subsection{Summary of Quantitative Approach to Site Characterization}

In an effort to avoid an open-ended, unfocused characterization program, the SWHC project will employ a quantitative approach to site characterization. Decisions made as part of this approach will be directly tied to regulatory issues regarding specific sites (Section 2.2). We will carefully consider all possible processes that might affect the hydrogeologic transport of contaminants to receptors as we attempt to identify particular characterization needs (Section 2.3). Once processes in need of characterization are identified, we will implement an iterative stochastic simulation/characterization procedure to define particular field characterization activities and refine our understanding of the site-wide hydrogeologic system. 


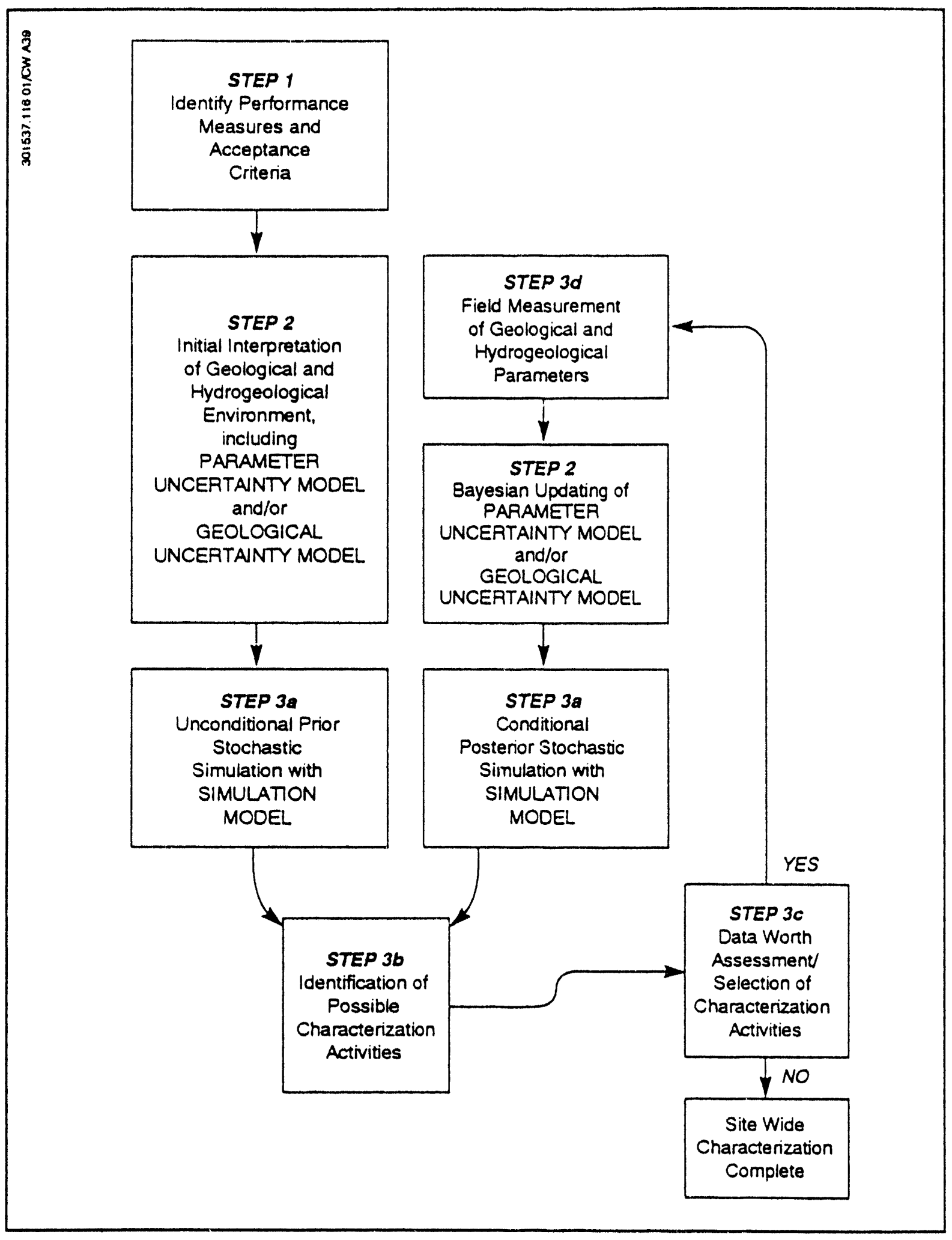

Figure 2-2. Summary of Decision Framework to Be Implemented as Part of the SWHC (Step numbers refer to general steps listed in Section 2.4; adapted from Freeze et al. 1990) 


\subsection{References}

Carrera, J., S. Olivella, and J. Samper, 1990. Network Design for Characterizing Heterogeneous Media: A Theoretical Framework, Dep. Ingeneria de Terreno, Universidad Politécnica de Cataluña, Barcelona, Spain.

Conrad, S. H., and P. T. Dickman, 1992. Using Performance Assessment to Direct Site Characterization Activities: An Example from the Greater Confinement Disposal Site, Proceedings of the 1992 Waste Management and Environmental Sciences Conference, San Juan, Puerto Rico, April 1992.

DOE (U.S. Department of Energy), 1988. Site Characterization Plan. Yucca Mountain Site, Nevada, vol. II, pt A, "Hydrology, Geochemistry, and Climatology," U.S. DOE/OCRWM.

Freeze, R. A., G. de Marsily, J. Massmann, and L. Smith, 1987. Some Uncertainties About Uncertainty, Proceedings of the Conference on Geostatistical, Sensitivity, and Uncertainty Methods for Ground-Water Flow and Radionuclide Transport Modeling, 1987.

Freeze, R. A., B. James, J. Massman, T. Sperling, and L. Smith, 1992. Hydrogeologic Decision Analysis: 4. Data Worth and the Development of Site Investigation Strategies, submitted to Ground Water, in press.

Loaiciga, H. A., 1989. An Optimization Approach for Groundwater Quality Monitoring Network Design, Water Resources Research, 25(8), pp. 1771-1782.

McCord, J. T., A. Treadway, F. C. Lauffer, and J. P. McCord, 1993. Quantitative Approach Toward Prioritization of Data Collection Activities for the SNL Site-Wide Hydrogeologic Characterization Project, SNL/NM ER Program Internal Report SWHC/2.0001, Sandia National Laboratories, Albuquerque, NM.

Peck A., S. Gorelick, G. de Marsily, S. Foster, and V. Kovalevsky, 1988. Consequences of Spatial Variability in Aquifer Properties and Data Limitations for Groundwater Modeling Practice, IAHS Publication No. 175.

Russell, C. E., 1990. Proposal for NTS Groundwater Characterization Program, Water Resources Center, Desert Research Institute, University of Nevada, Las Vegas, NV. 


\subsection{GEOLOGIC SETTING}

This section provides a summary description of the current state of knowledge of the SNL/KAFB geologic setting. This summary description includes information obtained from all major non-SNL/NM reports and from ER Program studies and projects. The geologic setting provides the overall framework for the SNL/KAFB hydrologic environment (see Section 4.0). The following sections include discussions on stratigraphy and geomorphology (Section 3.1), structural geology (Section 3.2), soils and vegetation (Section 3.3), hydrogeologic framework (Section 3.4), and a short description of recent work related to Travertine Hills surficial geologic mapping (Section 3.5). In addition, Section 3.6 provides a summary of existing geophysical data for the SNL/KAFB area, and Section 3.7 identifies geologic data gaps and uncertainties.

\subsection{Stratigraphy and Geomorphology}

The SNL/KAFB site lies within the northern portion of the Mexican Highland section (Rio Grande subsection) of the Basin and Range physiographic province (Fenneman 1931, Hawley 1986). Elevations within the rift valley in the Albuquerque area range from $4,900 \mathrm{ft}$ $(1,300 \mathrm{~m})$ along the Rio Grande to approximately $11,000 \mathrm{ft}(3,300 \mathrm{~m})$ at the crest of the Sandia Mountains. Elevations on SNL/KAFB, which lies immediately south of the city of Albuquerque, vary from $4,920 \mathrm{ft}(1,500 \mathrm{~m})$ adjacent to the Rio Grande to $7,988 \mathrm{ft}(2,435 \mathrm{~m})$ at Manzano Lookout Tower. KAFB has a mean elevation of 5,350 ft $(1,630 \mathrm{~m})$.

Geologically, SNL/KAFB is located in the east-central Albuquerque Basin (Figures 3-1 and 3-2), a major structural feature of the Basin and Range Province (Woodward 1982). The site sits on a partially dissected bajada built by at least three alluvial fan systems: Tijeras Arroyo fan, Arroyo del Coyote fan, and the Travertine Hills Arroyo fan at the eastern margin of the Sandia and Manzanita Mountains.

Stratigraphic units exposed on SNL/KAFB can be grouped into three units: (1) pre-Santa Fe Group Formations (Precambrian through early Cenozoic), (2) Santa Fe Group Formations (middle to late Cenozoic), and (3) post-Santa Fe Group Formations (late Cenozoic). Stratigraphic units that occur on portions of the SNL/KAFB site are briefly described in the following sections, beginning with the oldest units and ending with the youngest units. A generalized stratigraphic chart for the SNL/KAFB area is illustrated in Figure 3-3.

\subsubsection{Pre-Santa Fe Group}

The basement of the SNL/KAFB area consists of Precambrian igneous, metasedimentary, and metaigneous rocks. Other pre-Santa Fe Group rock units in the SNL/KAFB vicinity include Paleozoic sediments of Mississippian through Permian age, and early Cenozoic sediments. These Precambrian to early Cenozoic rocks predate development of the middle to late Cenozoic Rio Grande Rift. 


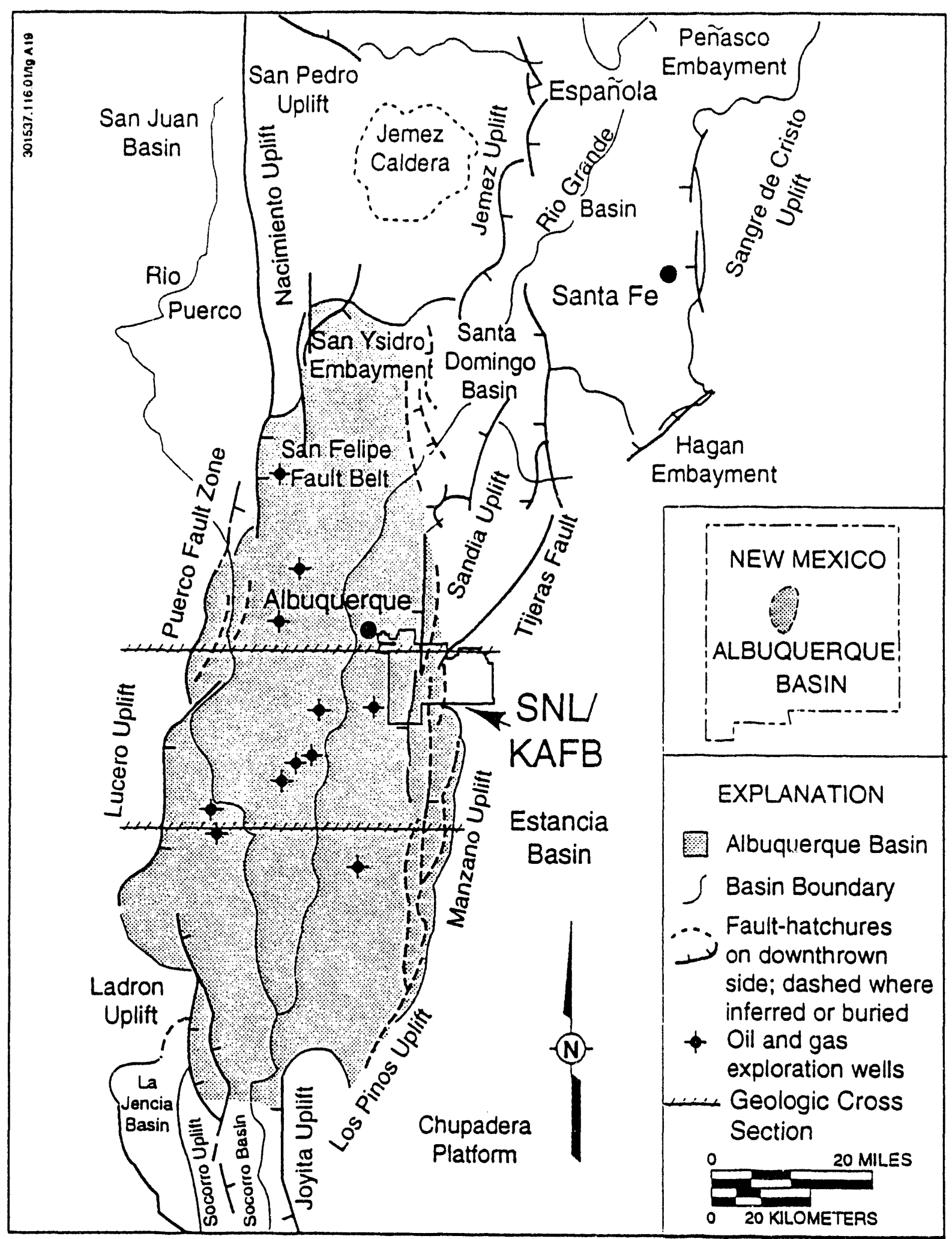

Figure 3-1. Tectonic Map of Albuquerque Basin, North-Central New Mexico (From Lozinsky et al. 1991) 


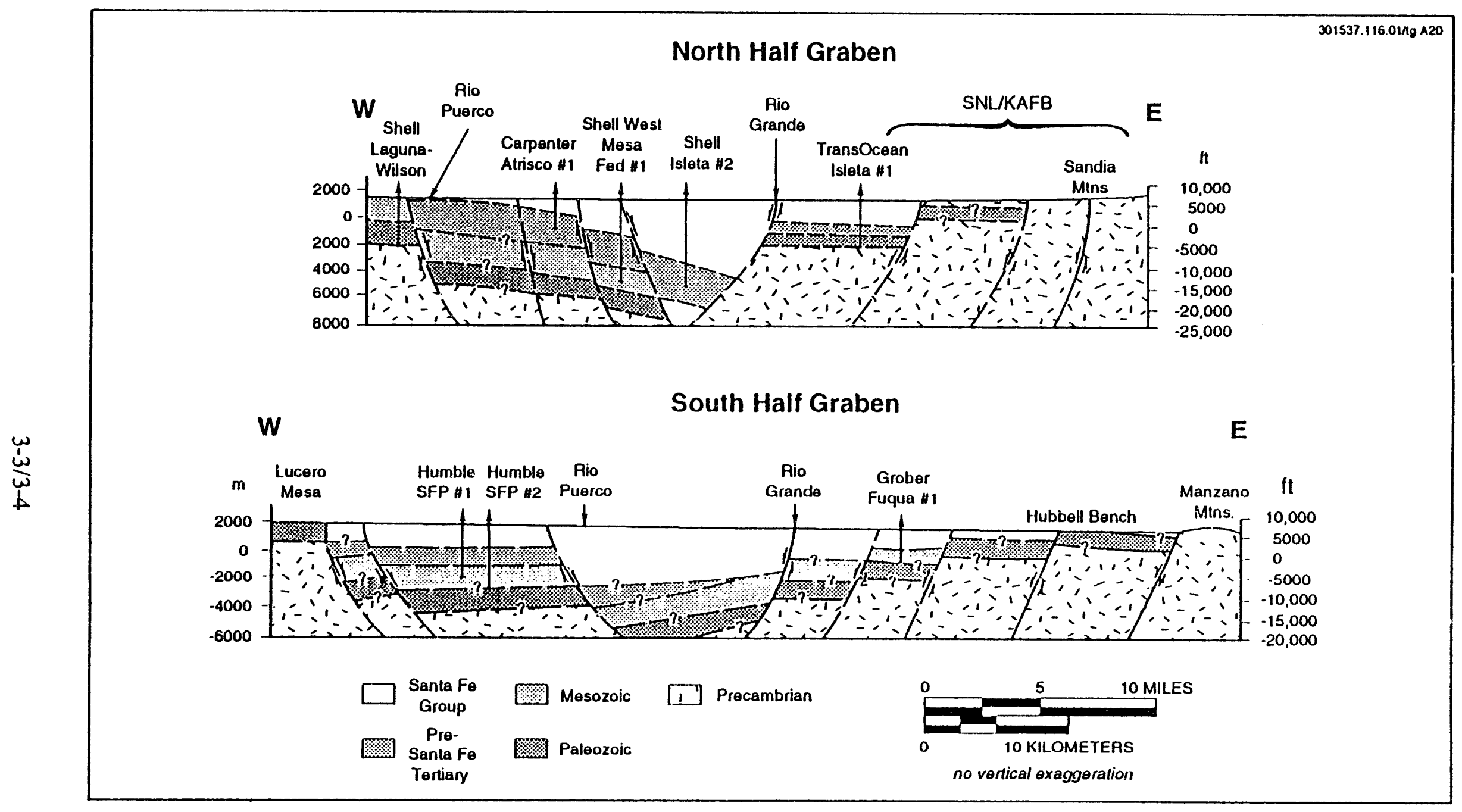

Figure 3-2. Diagrammatic Geologic Cross Sections of the Central Albuquerque Basin North and South of the Tijeras "Accommodation" Zone (From Lozinsky et al. 1991) 


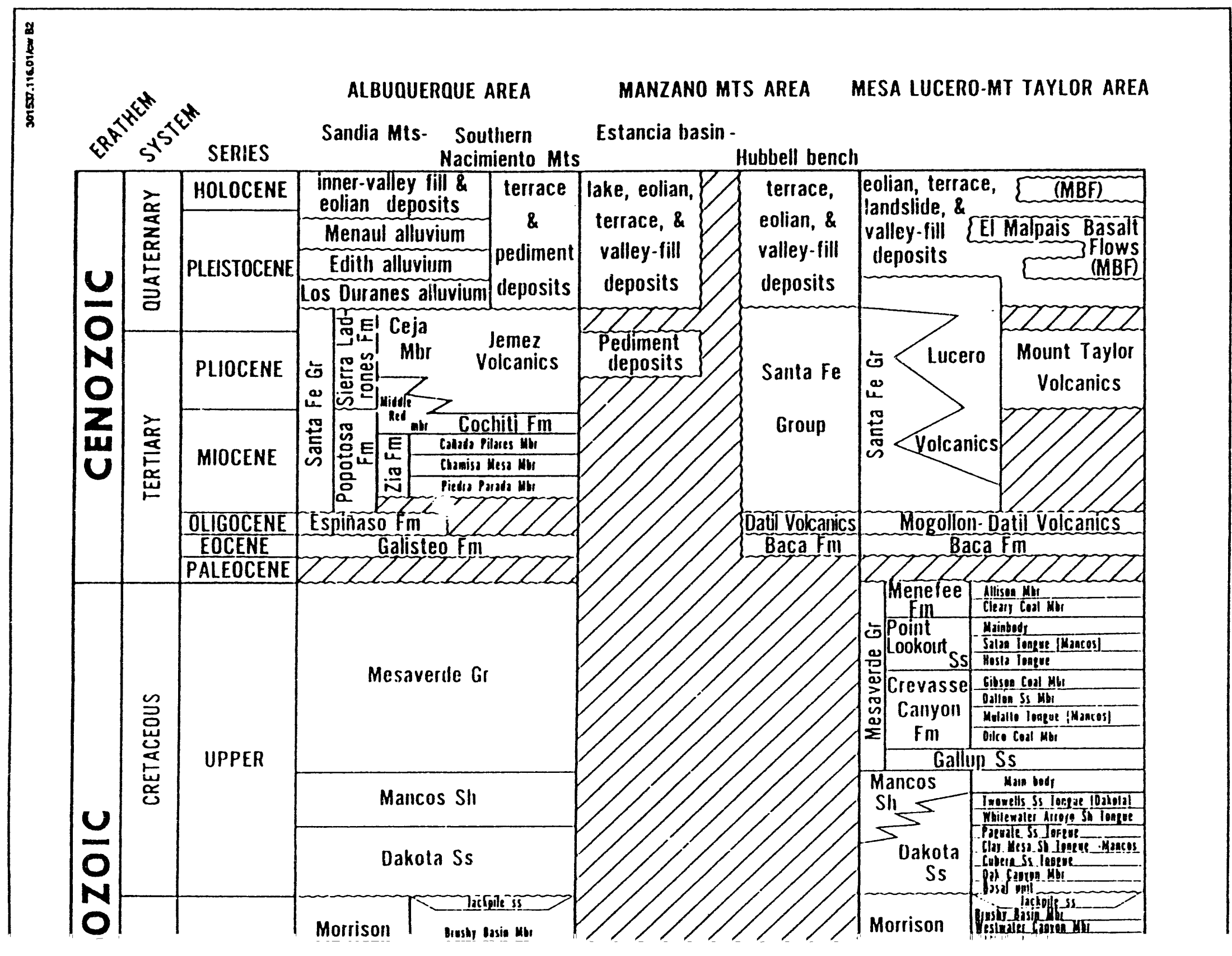




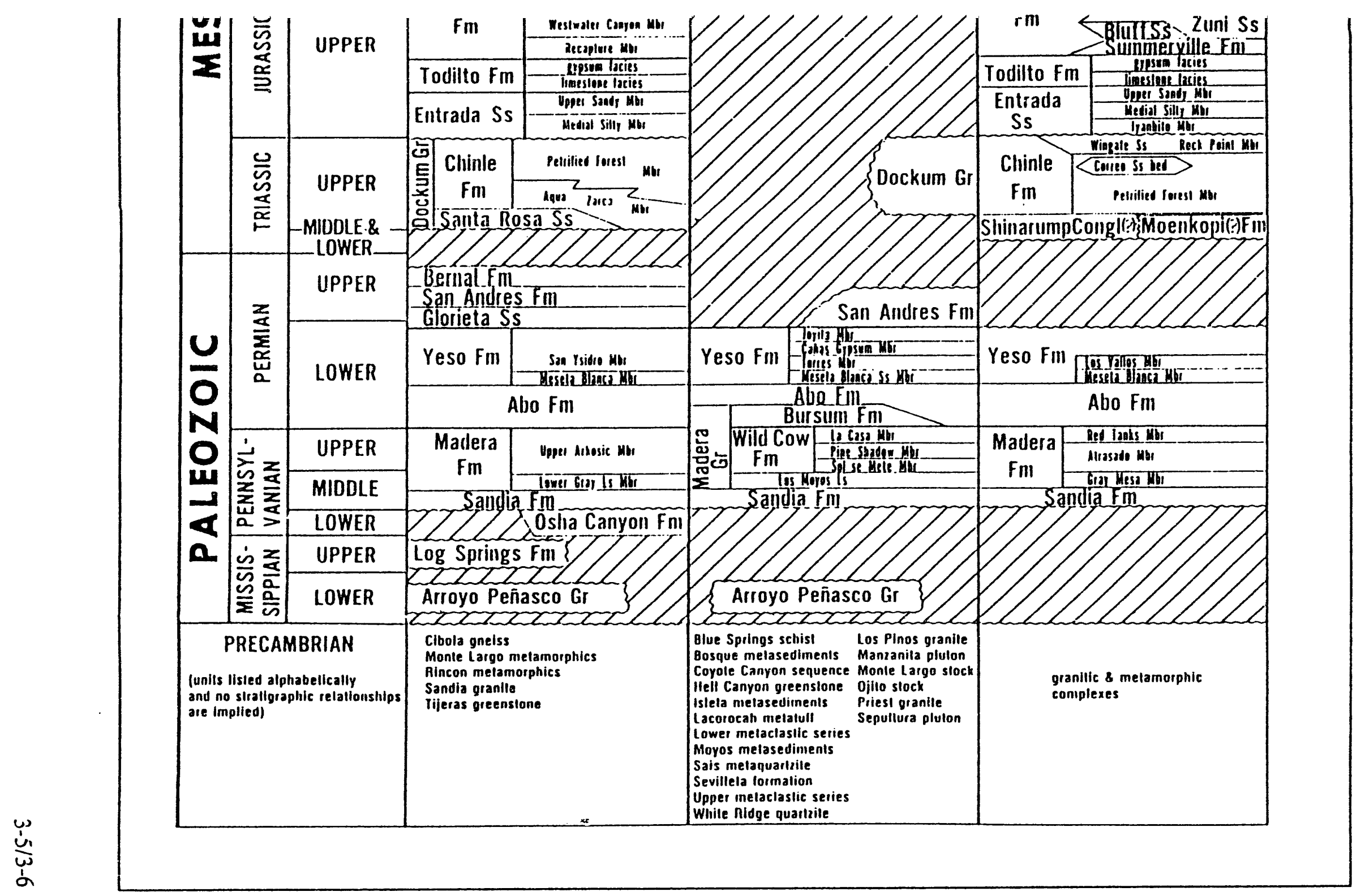

Figure 3-3. Stratigraphic Nomenclature Chart, Albuquerque Area (From Saucier et al. 1992) 


\subsubsection{Precambrian}

The Sandia, Manzanita, and Manzano Mountains contain the principal bedrock outcrops in the eastern portion of the SNL/KAFB area. The western front of the Manzano/Manzanita range has been uplifted along north-trending faults, exposing a Precambrian core composed principally of gneiss, schist, greenstone, quartzite, and granitic plutons. These same rock types also lie either directly beneath the basin fill or beneath the oldest Paleozoic Formations throughout much of the western margin of the Sandia, Manzanita, and Manzano Mountains. All Precambrian rocks in the SNL/KAFB area have experienced at least one major deformational episode and contain numerous fractures, faults, and other deformation features and fabrics.

Descriptions of the Precambrian geology of the Sandia, Manzanita, and Manzano Mountains adjacent to the SNL/KAFB area are provided by Reiche (1949), Myers and McKay (1971), Kelley and Northrop (1975), Myers and McKay (1976), Kelley (1982a), Woodward (1982), and Cavin et al. (1982). The following is a brief summary of the main Precambrian rock units (see Figure 3-3) that occur on the eastern portion of the SNL/KAFB site.

\section{Moyos Metasediments}

Moyos metasediments (Woodward et al. 1979) consist of phyllitic and schistose metaquartzite with minor interlayered greenstone near the top. Phyllites have well-developed schistosity that generally parallels the compositional layering, and they range in color from whitish, to light green, to brownish gray.

\section{Greenstone Complex}

The Greenstone Complex (Reiche 1949, Cavin et al. 1982) is a thick series of greenschistfacies units characterized by poor outcrops, rounded slopes, and a rubbly mantle of relatively infertile soil. Massive greenstone is common in the lower Hell Canyon area to the south of SNL/KAFB in the Manzano Mountains. North of Coyote Springs, in the northeastern portion of SNL/KAFB, chlorite schists are most prevalent.

\section{Bosque Metasediments}

Bosque metasediments (Cavin et al. 1982) contain light gray to bluish and greenish-gray, fine- to medium-grained metaquartzite, with subordinate amounts of muscovite and chlorite phyllite and minor greenstone in the lower portion of the sequence, and white and gray phyllite with subordinate micaceous metaquartzite and metasiltstone in the upper part of the unit.

\section{Locorocah Metatuff}

The Locorocah metatuff (Reiche 1949) is a light gray, poorly bedded to weakly schistose unit composed of dacite and rhyodacite with minor andesite. It contains abundant platy lithic 
fragments with a matrix composed of sodic plagioclase, quartz, fine-grained sericite, epidote, and minor chlorite (Cavin et al. 1982).

\section{Isleta Metasediments}

Isleta metasediments consist of tan, light gray, and light green phyllite, meta-arkose, and metaquartzite (Cavin et al. 1982). In exposures within the northern Manzanita and Manzano Mountains, metavolcanics are present within this unit.

\section{Coyote Canyon Sequence}

The Coyote Canyon sequence as described by Cavin et al. (1982) consists of the Cerro Pelon quartzite, an overlying unit of quartzite and phyllite, a thin quartzite, a wedge of felsic metavolcanics, Coyote greenstone, and a unit of mafic to intermediate metavolcanics with interbedded metasediments.

\subsubsection{Paleozoic}

Paleozoic Formations in the Albuquerque Basin are Mississippian to Permian in age and are both marine and nonmarine in origin. On most of the SNL/KAFB site, Paleozoic sediments occur at depths ranging from less than $100 \mathrm{ft}(30.5 \mathrm{~m})$ in the eastern portion, to greater than $10,000 \mathrm{ft}(3,049 \mathrm{~m})$ in the western portion. Details of stratigraphy and geology of Paleozoic rocks in the SNL/KAFB vicinity are summarized by Myers and McKay (1970), Myers (1973), Myers and McKay (1976), Kues et al. (1982), Kelley (1982a), Myers (1982), Saucier et al. (1982), Baars (1982), and Russell and Snelson (1990).

\section{Mississippian}

Mississippian strata are almost nonexistent in the SNL/KAFB area. The major occurrence is a dense, gray, fine-grained to oolitic, massive- to medium-bedded limestone in Tijeras Canyon (Kues et al. 1982), and outcrops of the Arroyo Penasco Group in the Manzano and Sandia Mountairs (Read et al. 1944).

\section{Pennsylvanian}

The marine and marginal marine rocks of the Pennsylvanian have been subdivided into the Sandia Formation and the overlying Madera Group (Figure 3-3). The Sandia Formation is a slope-forming sequence of olive-drab micaceous siltstone, sandstone, and conglomerate. Locally, it contains a few discontinuous thin beds of marine limestone. The Madera Group in the Hubbell Bench area, toward the southern edge of the SNL/KAFB site, is subdivided (Myers 1973, Saucier et al. 1982) into the Los Moyos Limestone (cliff-forming limestones), the Wild Cow Formation (a sequence of alternating sandstone, shale, and limestone beds), and the Permian Bursum Formation (nonmarine redbeds and marine limestone). In the Albuquerque area, including much of the SNL/KAFB site, however, the Madera Group contains only Pennsylvanian strata, and is simply divided (Saucier et al. 1982) into a lower gray limestone member and an upper arkosic member (Figure 3-3). 


\section{$\underline{\text { Permian }}$}

Permian strata in the SNL/KAFB area include the Bursum, Abo, and Yeso Formations. As previously noted, in the vicinity of Hubbell Bench, toward the southern edge of the SNL/KAFB site, the Bursum Formation is recognized to underlie the Abo Formation. In the Albuquerque area, which includes much of the SNL/KAFB site, the Bursum Formation is not recognized and the equivalent strata are assigned to the Abo Formation (Figure 3-3).

The Abo and Yeso Formations are massively to thinly bedded red sandstones, siltstones, and shales. Locally, gypsum-bearing intervals are noted, especially within the Yeso Formation. The Yeso Formation is exposed along the fault escarpments and adjacent arroyos near the convergence of the Hubbell Spring and Colorado Faults (Kelley 1982b). Abo Formation redbeds crop out north of EOD Hill (Myers and McKay 1971) and have been encountered in a pipeline trench just east of Lovelace Road (Krumhansl and McConnell, in preparation).

\section{Mesozoic}

The Mesozoic era, although represented in Albuquerque and the Sandia Mountains, apparently is almost entirely absent from the SNL/KAFB area. Where present, on the eastern basin margin, it directly underlies the Santa Fe Group.

\subsubsection{Pre-Santa Fe Group Cenozoic}

The principal Cenozoic rocks within the SNL/KAFB area are Eocene sandstones and fanglomerates of the Baca Formation (Figure 3-3). These sediments occur on the eastern portion of Hubbell Bench (Figure 3-4), near the southern edge of the SNL/KAFB site. Immediately south of the SNL/KAFB site, Lozinsky (1988) divided pre-Santa Fe Cenozoic deposits into Eocene Galisteo and Baca Formations composed of interbedded sandstone, siltstone, and shale. Available data suggest that all of the pre-Santa Fe Group sediments identified by Lozinsky (1988) are likely restricted to the deep subsurface under most, if not all, of SNL/KAFB.

\subsubsection{Santa Fe Group}

The Santa Fe Group constitutes the principal basin-fill sediments of the Albuquerque Basin. The Group consists of interbedded gravels, sands, silts, and clays deposited as alluvial fans from the nearby mountains, fluvial deposits of material transported by rivers from more distant source areas outside the basin, and locally thick playa-lake and eolian deposits (Lozinsky 1988, Ingersoll et al. 1990, Lozinsky and Tedford 1991, Hawley and Haase 1992). The Santa Fe Group is up to $14,500 \mathrm{ft}(4,400 \mathrm{~m})$ thick in the central portion of the rift near the western margin of the SNL/KAFB site (Hawley and Haase 1992).

The stratigraphy of the Santa Fe Group is complex (Figure 3-3). Hawley and Haase (1992) subdivided the Santa Fe Group into lower, middle, and upper units based on depositional environments and age, and that subdivision will be used in this report. Additional discussion of Santa Fe Group stratigraphy, sedimentology, and petrology are provided by Spiegel and 


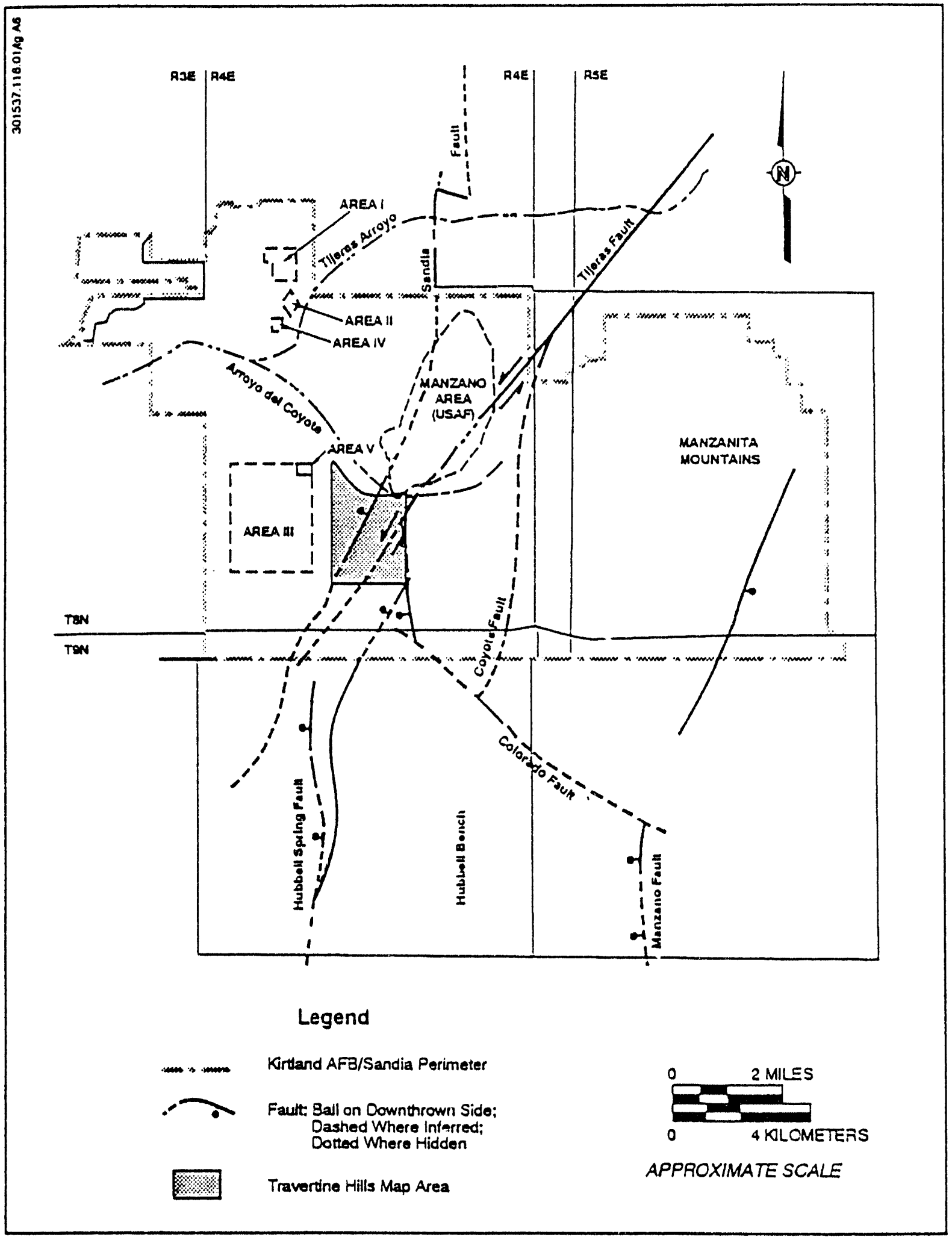

Figure 3-4. Major Structural Features of the SNL/KAFB Region (From DOE 1987) 
Baldwin (1963), Lambert (1974), Kelley (1977), Hawley (1978), Machette (1978a and b), Lambert et al. (1982), Chapin (1988), Ingersoll et al. (1990), and Hawley and Haase (1992).

\subsubsection{Lower Santa Fe Group}

The lower Santa Fe Group (Hawley and Haase 1992) is dominated by intertonguing piedmont-slope, eolian, and fine-grained basin-floor deposits. Fan and coalescent-fan alluvium characterize the piedmont-slope deposits, whereas playa sediments and playa-margin alluvium are the major components of the basin-floor deposits. The deposits range in age from about 30 to $15 \mathrm{Ma}$ (million years) and represent deposition in an internally drained basin prior to deep subsidence and uplift of high-flanking mountain blocks.

\subsubsection{Middle Santa Fe Group}

The middle Santa Fe Group (Hawley and Haase 1992) was deposited between about 15 and $5 \mathrm{Ma}$, when tectonism was most active in the basin. Piedmont-slope sediments continued at the margins of the basin, but major fluvial systems from the north, northeast, and southwest were also transporting sediments into the basin. Thus, during the middle Santa Fe time, fluvial deposition was also occurring on the basin floor. However, these fluvial systems probably terminated in playa lakes in the southern part of the basin (Lozinsky and Tedford 1991). Due to the high tectonism and resulting high sedimentation rates, the bulk of the Santa Fe Group was deposited at this time, and the two half-basins (see Section 3.2) filled to form a single topographic basin.

\subsubsection{Upper Santa Fe Group}

About $5 \mathrm{Ma}$ ago, the through-flowing ancestral Rio Grande system developed (Lozinsky et al. 1991), forming a large aggradational plain in the central basin area. The upper Santa Fe Group was deposited during the next $4 \mathrm{Ma}$ and is characterized by intertonguing piedmont-slope and fluvial basin-floor deposits. Piedmont-slope deposits (alluvial and debrisflow) consist of poorly sorted, weakly stratified sand and conglomerate, commonly with a silt-clay matrix. Basin-floor deposits include cross-stratified ancestral river sediments characterized by thick zones of clean sand and pebble gravel. Fine- to medium-grained overbank sediments were deposited in areas where major river systems were merging and in basin-floor and piedmont-slope transition zones. The thickness of the upper Santa Fe deposits is locally as much as $1,500 \mathrm{ft}(457 \mathrm{~m})$, but usually less than $1,000 \mathrm{ft}(305 \mathrm{~m})$.

\subsubsection{Post-Santa Fe Group}

Post-Santa Fe units include fan, pediment, inset-terrace, eolian, and floodplain deposits (Lambert 1968, Hawley and Haase 1992). Rock pediment and graded alluvial slopes generally occur on piedmont surfaces that extend from the bases of the Sandia, Manzanita, and Manzano Uplifts on the eastern side of the basin. They represtint stable periods or intervals of aggradation following erosional episodes and include the Llano de Manzano and Llano de Sandia, on which the SNL/KAFB sites are located. Fills related to cutting and partial backfilling of these piedmont surfaces, or terraces, by the Rio Grande Valley during glacial-interglacial cycles form at least three inset-terrace deposits, and include the Primero 
Alto and Segundo Alto river terraces (Bryan 1909, 1938; Bryan and McCann 1938; Lambert 1968; Hawley et al. 1976; Machette 1978a-c, 1985; Lambert et al. 1982; Hawley and Love 1991). Terrace fills are mapped along the valley border as the Menaul, Edith, and Los Duranes alluvium (Lambert 1968, Lambert et al. 1982)(see Figure 3-3). Thicknesses of these units range from 30 to $200 \mathrm{ft}(9$ to $61 \mathrm{~m})$. The latest cut-and-fill episode of the Rio Grande-Puerco system produced the channel and floodplain deposits of present inner-valley areas.

\subsubsection{Geomorphology}

Part of SNL/KAFB is located on at least three alluvial fan complexes into which Tijeras Arroyo, Arroyo del Coyote, and an unnamed arroyo to the south of Arroyo del Coyote have incised. Several units within these complexes were examined in detail during 1990-91 when a sewer trench was excavated, mainly in a northwest/southeast direction that cut through the medial portion of the Arroyo del Coyote fan complex and medial to proximal portions of the Travertine Hills alluvial fan complex (Figure 3-5). This excavation provided an opportunity to document a portion of the surficial and shallow subsurface geology of the area, which was done with a series of geologic cross sections, field rotes, and photographs. Results of this work are found in Geologic Mapping of the Sanitary Sewer Line Excavation, Southern Sandia National Laboratories, Albuquerque, New Mexico (IT 1992), and geostatistical analysis of the geologic sections will be presented in the report by McCord et al. (1993).

The semiarid environment of the SNL/KAFB area results in ephemeral streams; intermittent streams are found only where they are supported by springs. Overland flow on alluvial fan and bedrock surfaces runs into braided, migratory channel systems that episodically deposit their bedloads. Channels are characteristically shallow and are associated with alternating aggradation and degradation on active portions of the fans. The fine-grained, terminal outer fan or fan-fringe deposits typically interweave with other depositional systems, such as the coarse-grained axial channel deposits of the Rio Grande. Generally, proximal facies (upper and inner parts of an alluvial fan) contain the coarsest sediments in highly channeled lenticular beds, whereas distal facies have less channelized, sheet-like beds.

The Tijeras Arroyo fan complex has its fan apex at the western mouth of Tijeras Canyon, where Interstate-40 emerges into the eastern area of metropolitan Albuquerque (Connolly et al. 1982, Smith et al. 1982). The upper portion of the Tijeras drainage basin is located on the eastern slopes of the Sandia and Manzanita Mountains. Some of this drainage basin lies to the east of Tijeras Canyon, which is in part formed by the Tijeras-Canoncito Fault system (see Section 3.2). Smaller drainage basins further to the south (e.g., Arroyo del Coyote and the unnamed arroyo to the south) drain the western range front of the Manzanita Mountains.

The Four Hills (see Manzano Base, Figures 1-2 and 3-5) are in the north-central portion of the SNL/KAFB area and provide a barrier to the southward migration of the Tijeras Arroyo. Four Hills, where the U.S. Air Force-operated Manzano Base is located, consists of a large bedrock outcrop that lies southeast of Tijeras Arroyo and east-northeast of TA-III. The colluvial and alluvial apron around this bedrock block has some of the steepest ( 2 to 3 degrees) nonbedrock slopes in the study area. 


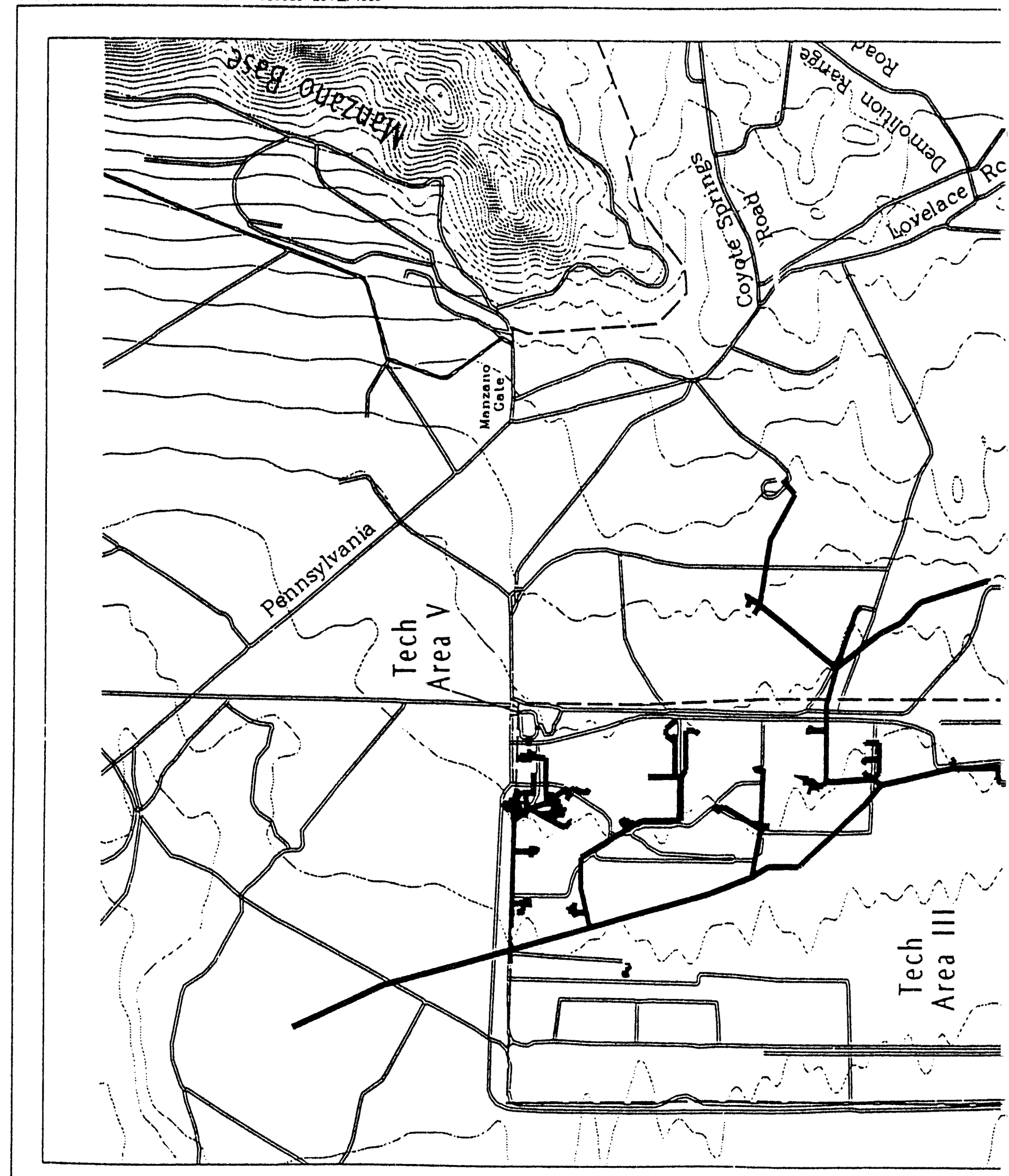

Figure 3-5. Location Map of SNL/KAI 
Arroyo del Coyote is a tributary to Tijeras Arroyo that drains a large area of the Manzanita Mountains, as well as the southeastern Four Hills. Coyote Canyon extends northeast into the Manzanita Mountains, and Arroyo del Coyote extends west from the canyon to the southern tip of Four Hills, where Arroyo del Coyote turns northwest to join Tijeras Arroyo. Arroyo del Coyote flows through bedrock to the south of Manzano Base. This bedrock constriction is the apex of a fan built by Arroyo del Coyote that extends over northern and central TA-III. The Arroyo del Coyote fan extends slightly more than $2 \mathrm{mi}(4 \mathrm{~km})$ to the west of the southern tip of the Four Hills. Features located on this fan include the northeast half of TA-III (including the MWI), TA-V, and the riding stable located northeast of TA-III. The present channel of Arroyo del Coyote is entrenched on the northern margin of the fan.

The unnamed arroyo drains the Manzanita Mountains west of Sol se Mete Peak (see Manzano Lookout Tower, Figure 1-2) and extends west through the Travertine Hills area. This arroyo has built a fan that extends more than $1 \mathrm{mi}(2 \mathrm{~km})$ to the west, past the CWL. The present active channel on the Travertine Hills fan extends northwest before turning into the central area of TA-III. Slopes on both the Travertine Hills fan and the Arroyo del Coyote fan average 1 degree. Slopes to the west of these fans become even more gentle. Slopes are also 1 degree or slightly less in the south and east of these fans. The Hubbell Spring Fault truncates ridge noses southwest of the ITRI.

\subsection{Structural Geology}

The Albuquerque Basin has undergone several kilometers of east-west extension along predominantly normal faults since mid-Tertiary time, approximately over the last 30 to $40 \mathrm{Ma}$, with extension continuing today (Lozinsky et al. 1991). Many faults within the basin are concave-upward (i.e., listric), normal faults that merge into a basal extensional or detachment fault (Figure 3-4). The basin is surrounded by fault-bounded basement uplifts: the eastward-tilted Sandia-Manzano-Los Piños Uplift on the eastern margin, and the Ladron and Lucero Uplifts on the southern basin border. Although the basin appears as a single, continuous topographic basin, seismic reflection work by Shell Oil Company indicates that the basin consists of two subbasins: a northern eastward-tilted half-graben and a southern westward-tilted half-graben (Russell and Snelson 1990) (see Figure 3-2). These two half-grabens are believed to be separated by an extension of the Tijeras Fault Zone, renamed the Tijeras Accommodation Zone by Lozinsky (1988). The half-grabens within the Albuquerque Basin are characterized by a deep, sediment-filled, inner depression flanked by a stepped sequence of shallow, faulted ramps that lead up to the basin margins. Faults with the largest displacements occur several kilometers basinward from the range-front faults next to the Sandia-Manzanita-Manzano or Lucero-Ladron Uplifts. Structural relief of the basin is well over $32,800 \mathrm{ft}(10,000 \mathrm{~m})$, based on the vertical separation of Precambrian strata from the top of the eastern margin uplifts to the deepest portion of the basin.

The two half-grabens of the Albuquerque Basin have opposite senses of displacement. With as much as $9,410 \mathrm{ft}(2,870 \mathrm{~m})$ of vertical offset, the largest displacement fault in the northern half-graben is located to the east under the present position of the Rio Grande. In contrast, the largest displacement fault in the southern half-graben appears to occur toward the western margin of the basin under the present position of the Rio Puerco (Figure 3-1). 
These two faults seem to control, at least in part, the courses of the Rio Grande and Rio Puerco, respectively, through the Albuquerque Basin.

SNL/KAFB lies directly over the intersection zone of several major faults along the eastern boundary of the Albuquerque Basin. The northeast-trending Tijeras Fault Zone separates differential movement between the northern and southern parts of the Albuquerque Basin. This zone apparently controls volcanism, as seen by the Quaternary Cerro de Los Lunas volcanic complex near Los Lunas, south of Albuquerque. The north-south-trending Sandia and Hubbell Spring Faults interact with the Tijeras Fault Zone. Other faults, such as the Colorado and Coyote Faults, also play important roles in the rift tectonics of SNL/KAFB. In general, however, little geologic field work has been done on SNL/KAFB and the Isleta Pueblo Indian Reservation to the south because of lack of access to the general public. This is especially true for the younger basin fill: the upper Santa Fe Group and post-Santa Fe Group units.

SNL/KAFB straddles several faults of the eastern margin of the Albuquerque Basin. These include the Tijeras, Hubbell Spring, Sandia, Manzano, Colorado, Coyote, and other associated faults (Figure 3-4).

\subsubsection{Tijeras Fault}

The Tijeras Fault Zone is one of the major cross-cutting features of the Rio Grande Rift (Kelley 1977, 1982b; Lisenbee et al. 1979). This zone can be traced for about $58 \mathrm{mi}$ $(93 \mathrm{~km})$ from the central portion of SNL/KAFB to the Canoncito area of the Sangre de Cristo Mountains about $14 \mathrm{mi}(9 \mathrm{~km})$ southeast of Santa Fe, New Mexico. Chapin et al. (1978) have mapped several major crustal northeast-trending lineaments across New Mexico and Colorado. These lineaments are thought to be shear zones that dominate the structural grain of Precambrian rocks in the southern Rocky Mountains, tend to be oriented along zones of Laramide-age volcanic plutons as well as recent lava flows of predominantly basaltic composition, and generally coincide with well-known mineral belts. Where these lineaments cross the Rio Grande Rift, they produce a characteristic suite of structural elements where, among other complex features, high heat flow and geothermal activity are common. Although not included in the lineaments described by these investigators, the Tijeras Fault Zone would appear to have similar qualities for age, trend, displacement, mineralization (e.g., Tijeras Canyon, San Pedro, Ortiz, and, by extension, Pecos mining districts), volcanism (e.g., Cerro Verde, Lucero Mesa, Cat Hills, Wind Mesa, and Isleta volcanic centers just west of the Rio Grande), and apparent basement complexity. As was discussed in Section 3.2, the Tijeras Fault Zone might represent a long-lived accommodation zone that separates differential subsidence between distinct northern and southern half-grabens within the Albuquerque Basin [see Ander (1980), Cordell (1978), Lozinsky (1988), and Lozinsky et al. (1991)].

Many episodes of movement from the Precambrian to the Quaternary are recognized for the zone (Lisenbee et al. 1979). Precambrian bedrock is faulted against Quaternary terrace deposits in Tijeras Canyon (Lisenbee et al. 1979, Connolly et al. 1982). Whether there has been Holocene movement along any segment of this fault remains controversial. The relationship of the Tijeras Fault on SNL/KAFB to surrounding faults, such as the Sandia 
Fault to the north and the Hubbell Spring Fault to the south, is not clear. Certain published references suggest that the Tijeras Fault displaces both the Sandia and Hubbell Spring Faults [e.g., Machette (1982)]. In the most detailed neotectonic study of the eastern and southeastern portions of the Albuquerque Basin to date, Machette (1982) suggests that the Tijeras and four or more other unnamed faults have been active on SNL/KAFB and Isleta Pueblo Indian Reservation during the Holocene (i.e., the last 10,000 yrs). He believes that the most recent movement on the main trace of the Hubbell Spring Fault was in the late Pleistocene (150,000 to 10,000 yrs B.P.). Other investigators, such as Grant (198?), believe that Hubbell Spring Fault cuts the Tijeras Fault. Maps by stiil other investigators [e.g., Figure 1 of Kelley (1982b)] represent the Tijeras and Hubbell Spring Faults as two distinct, down-to-the-northwest normal faults that are parallel to each other for several kilometers on SNL/KAFB but never intersect.

The Tijeras Fault Zone has had as much as $1.5 \mathrm{mi}(2.41 \mathrm{~km})$ of left-lateral, post-Cretaceous offset (Kelley and Northrop 1975). The vertical sense of Tertiary-through-Quaternary offset along the zone is equivocal. Lozinsky's (1988) work suggests that across the entire Tijeras Fault Zone the net Tertiary-through-Quaternary displacement is down-to-the-northwest. This would agree with his explanation of the differential subsidence in the northern half-graben of the Albuquerque Basin. In more detailed studies of the Tijeras Fault on SNL/KAFB, Reiche (1949), Riddle and Grant (1981), Grant (1982), and Krumhansl and McConnell (in preparation) believe that at least the main trace of the Tijeras Fault on SNL/KAFB has downto-the-southeast net offset. These investigators place the Tijeras Fault on the southeast side of the Four Hills area in the southeastern Albuquerque area. The Precambrian Sandia granite of the Four Hills Uplift structural block (Grant 1982) on the northwest side of the Tijeras Fault is uplifted relative to the Precambrian quartzites, Pennsylvanian limestones, and upper Tertiary basin fill on the opposite side of the fault. Reiche (1949), who showed a similar relationship of units across the Tijeras Fault Zone, was not able to measure vertical separation of these units across the fault, but presumed this offset to be measured in thousands of feet. Various authors [e.g., Lozinsky et al. (1991)] have suggested a scissorslike vertical movement on the Tijeras Fault Zone, with variable downdropping to the northwest and to the southeast on different portions of the fault. Vertical movements of structural blocks within the Tijeras Fault Zone have been inferred for the Tijeras graben to the northeast of Tijeras Canyon and the Monte Largo Horst (Maynard et al. 1991). A similar horst-like geometry within the Tijeras Fault Zone might occur within the Precambrian units of Four Hills and the Manzano Base area [e.g., Grant's (1982) Four Hills Uplift]. In summary, the details of the role played by the Tijeras Fault Zone and its relationship to other faults on SNL/KAFB remains equivocal.

\subsubsection{Hubbell Spring Fault}

The north-south-trending Hubbell Spring Fault runs parallel to the Manzano Fault along the eastern side of the Albuquerque Basin (Figure 3-4). It is one of a series of faults that downdrop bedrock in the central portion of the rift by up to $6.4 \mathrm{mi}(10 \mathrm{~km})$. The fault is apparently unbroken for about $36 \mathrm{mi}(58 \mathrm{~km})$ from the southeast part of T8N, R4E to its northern end, where it joins a series of northeast-trending faults, possibly including the Tijeras Fault Zone. If the presumed Sandia Fault is an extension of it, the combined Hubbell Spring-Sandia Fault length would be some $22 \mathrm{mi}(35 \mathrm{~km})$ longer than originally thought, for 
a total of $58 \mathrm{mi}(92 \mathrm{~km})$. The Hubbell Spring Fault has a strikingly linear trace and is aligned with a series of freshwater springs in the northern $18 \mathrm{mi}(29 \mathrm{~km})$ of its length. These springs, the Ojo Huelos, Carrizo, Maes, Ojo de la Cabra, and Hubbell, are located on an otherwise barren, semiarid mesa some 4 to $6 \mathrm{mi}(16$ to $10 \mathrm{~km})$ west of the Manzano Mountain range front. The springs are best identified by large cottonwood trees, which are the only trees on the East Mesa.

Fault scarps related to this fault are perhaps the most spectacular in this part of the Rio Grande Rift (Machette 1982). Relatively recent movement has raised a prominent scarp along its northern length on the eastern side of the fault. The scarp rises 100 to $150 \mathrm{ft}$ (30 to $46 \mathrm{~m}$ ), is sharply defined, is incised by east-west arroyos, and is supported by an apparently homogeneous block of flat-lying sedimentary units of Triassic through Pennsylvanian age that overlie Precambrian rocks. These sediments are exposed in the vicinity of the Ojo Huelos and Hubbell Spring and appear to be covered by a thin veneer of alluvial-fan material elsewhere.

The Hubbell Spring Fault was first mapped and named the Ojuelos Fault by Read et al. (1944). No detailed investigations of the scarps or Quaternary deposits associated with this major fault had been made before the study by Machette (1982), except for Reiche's (1949) reconnaissance studies. Reiche (1949, pp. 1203-1204) stated that the Hubbell Spring Fault "developed during the Pliocene; Quaternary movements were relative minor, recurrent and apparently most recent at the south." He also implied that the most recent movement on the fault is Holocene. Although there is ample evidence of multiple fault movements during the Quaternary, observations of fault-scarp morphology made by Machette (1982) do not support Holocene movement. This technique, which uses the progressive degradation of fault scarps through time, remains experimental as an absolute-age determination technique. Scarpmorphology data collected along two segments of the Hubbell Spring Fault by Machette (1982) indicate that the most recent movement of the southern half of the Hubbell Spring Fault might have occurred during late Pleistocene time. Scarp heights along this part of the fault range from as little as 13 to $16 \mathrm{ft}(4$ to $5 \mathrm{~m})$ in upper Pleistocene deposits to as much as $98 \mathrm{ft}(30 \mathrm{~m})$ for compound fault scarps formed in lower (?) Pleistocene or Pliocene deposits. On the basis of air-photo reconnaissance, Machete (1982) concluded that the northern half of the Hubbell Spring Fault has a history of recurrent movement and recency similar to that of the southern half.

Although Machette (1982) places the most recent movement on the Hubbell Spring Fault as late Pleistocene $(150,000$ to 10,000 yrs B.P.), he shows five faults on the Isleta Pueblo Indian

Reservation and SNI/KAFB that have apparently had movement in the Holocene. Several of these faults are probably connected structurally to the Hubbell Spring Fault. Other faults identified by Machette, which lie in the western portion of the Isleta Pueblo Indian Reservation and perhaps SNL/KAFB, are not associated with any named faults.

\subsubsection{Sandia Fault}

The Sandia Fault (Kelley 1977, Kelley and Northrop 1975, Woodard et al. 1975) lies at the range front of the Sandia Mountains to the east of the city of Albuquerque (Figure 3-4). The fault is one of several that downdrop structural blocks to the west into the axis of the 
Albuquerque Basin. The fault extends from the southwest extension of the Four Hills Uplift on KAFB to the Placitas area of Sandoval County, a north-south distance of about $25 \mathrm{mi}$ $(40 \mathrm{~km})$. Kelley and Northrop (1975) report evidence of surface rupture at only three locations. To the south, a fault is exposed at the mouth of Tijeras Canyon on the east side of the road leading into the Four Hills Subdivision in approximately the center of the west half of Section 26, T10N, R5E. Another exposure is a minor scarp located by Kelley at the base of the Rincon spur of the Sandia Mountains on the Sandia Pueblo Indian Reservation. The third outcrop is apparently where the fault crosses Highway NM-44 near the northern end of the Sandia Fault in Section 1, T12N, R4E. Other evidence for the Sandia Fault is found in the gravity maps of Cordell et al. (1978) and Aiken et al. (1978). Cordell et al. (1978) postulate a buried fault beneath a steep, linear gravity gradient taken from a detailed profile along Tramway Road between Interstate- 25 and the Juan Tabo Picnic Area (approximately the southwest corner of Section 3, T11N, R4E). He models this gravity anomaly as being a single, large, steep fault with structural relief at least 3,000 to $6,000 \mathrm{ft}$ (914.4 to $1,828.8 \mathrm{~km})$.

Evidence for this fault bounding the west side of the Four Hills Uplift part of the Sandia Mountains on KAFB is somewhat subjective. Geologically, a major fault should be present here in order to account for the structural relief between the deepest parts of the rift identified by well data and the top of the Sandia Mountains, apparently more than $30,000 \mathrm{ft}$ $(9,000 \mathrm{~m})$.

Reiche (1949) mapped a fault on the surface extending southwest through the north-central part of Section 22 to the center of Section 28, T9N, R4E. He describes a small alluvial fan built by Arroyo del Coyote at this location as being offset vertically about $25 \mathrm{ft}(8 \mathrm{~m})$ and, "Although the scarplet is battered, the evidence is definite; it includes small fissure fillings of travertine due to a former artesian spring." A field investigation by Grant (1981) failed to locate the scarp Reiche describes. Travertine is present at this locality, however, and the location has prior to Grant's field work been subjected to considerable earth moving for roads and a bridge across Arroyo del Coyote along Lovelace Road.

The general structural geology of the Albuquerque Basin suggests that the Sandia Fault must lie immediately west of the Precambrian outcrops. Krumhansl and McConnell (in preparation) found an eroded fault scarp exposed in the Arroyo del Coyote channel bottom immediately west of the Lovelace Road Bridge across this arroyo that they believe is correlative to the Sandia Fault. Although the break occurs west of the bridge, the rise in the streambed does not occur until about $100 \mathrm{ft}(30.5 \mathrm{~m})$ east of the bridge. A step is found in the streambed where it is supported by the first appearance of heavily cemented conglomerate [also known as travertine (Riddle and Grant 1981)]. East of this location for at least 2,000 ft $(600 \mathrm{~m})$, the stream flows on this material. However, west of the eroded fault scarp, this unit is never seen again. The fault zone proper exposes a block of sheared gneiss on the east side and a seemingly upthrown block of travertine (Riddle and Grant 1981) to the west. This suggests that the fault has broken in relatively recent times. However, geomorphic surfaces just south of the stream show no evidence of offset (Krumhansl and McConnell, in preparation). Thus, the exposures in the streambed might reflect an older, buried fault scarp that has just recently been excavated. 


\subsubsection{Manzano Fault}

The Manzano Fault has been shown by many authors [e.g., Read et al. (1944) and Machette (1982)] to be a major rift-bounding normal fault at the base of the Manzano Mountains (Figure 3-4). Movement along this fault probably formed the precipitous range front of the Manzano Mountains, although Machette (1982) found no evidence of fault scarps developed in Holocene to middle Pleistocene deposits along the mountain front. The Manzano Fault is marked by a wide zone in which early Miocene tuffaceous sedimentary rocks and andesite (as well as older rocks) are steeply rotated into fault contact with Paleozoic and Precambrian rocks. The Manzano Fault probably begins near Tijeras Canyon on the north and extends about $34.8 \mathrm{mi}(56 \mathrm{~km})$ south to the Abo Pass area (between the Manzano and Los Piños Mountains), where it might join the Los Piños Fault.

Kelley (1982b) describes how the Manzano Fault and its possible southern extension, the Los Piños Fault, separate Pennsylvanian through Triassic beds from Precambrian units within the Manzano Mountains. The northern end of the fault interacts with the northwest-trending Colorado Fault and perhaps Laramide-age thrust faults within the Manzano and Manzanita Mountains, such as the Montosa Fault of Kelley (1982b).

\subsubsection{Colorado Fault}

The northwest-trending, down-to-the-southwest Colorado Fault lies in the southwestern portion of the SNL/KAFB area (Figure 3-4). North of this fault, bedrock exposures along Hubbell Bench consist of Pennsylvanian and Precambrian units (Kelley 1982b). Southward between the Colorado and Hubbell Spring Faults in T8N, the top of the Precambrian might be as much as $5,900 \mathrm{ft}\left(1^{-} \mathrm{m}\right)$ below the surface. Lack of bedrock exposures in the large area to the south of the Colorado Fault precludes speculation as to what formations or structures are present (Kelley 1982b). The Colorado Fault is primarily recognized by offset of the northern half of the Manzanita Mountains range front by about $4 \mathrm{mi}(6.44 \mathrm{~km})$ to the northwest (Kelley 1977).

At the south end of Travertine Hills is a southeast-trending linear feature defined by the truncation of several small hills in a manner atypical of local erosion patterns (Krumhansl and McConnell, in preparation). Farther southeast along this lineament is a linear drainage that might trend toward the sewage treatment lagoons at the ITRI. This suggests that the southern boundary of Travertine Hills is fault-controlled. This lineament might be an extension of the Colorado Fault.

\subsubsection{Coyote Fault}

The Coyote Fault (Reiche 1949, Kelley 1982b), which is responsible for the initial scarp of the northern two-thirds of the Manzanita Mountains, strikes N16 $\mathrm{W}$ and dips $77^{\circ} \mathrm{W}$ in a trench southwest of Coyote Springs (see Figure 4-4). At this locality, the throw on the Coyote Fault is about 1,300 ft (396 m) with down-to-the-south offset. On the west side of the fault zone, the bedding is dragged to nearly vertical against the quartzite in the footwall. Hence, the northern part of Hubbell Bench is a small graben that widens and opens to the southwest. A fault in Section 1, T8N, R4E, might be part of the same structure. The 
Coyote Fault, therefore, has an inferred total length of about $4.5 \mathrm{mi}(7.2 \mathrm{~km})$, and might extent farther south than described here.

\subsubsection{Other Faults}

The low hills east of Lovelace Road contain abundant outcrops of Paleozoic sandstones, quartz pebble conglomerates, and, most prominently, limestones. Detailed examination by Krumhansl and McConnell (in preparation) reveal this to be an area of complex structure. It is crossed by at least two sets of probable normal faults. The dominant set has a generally north-south orientation, but at least one important fault in the area trends almost due eastwest. Correlations across these faults are difficult because the exposure of underlying Paleozoic bedrock is not continuous, and geomorphic surfaces are apparently not offset. Several Paleozoic units, including the Madera Formation, might prove useful for correlation in further mapping efforts. Units are locally fossiliferous, with abundant bryozoa and crinoids. Other units have distinct coloration, weathering characteristics, and fracture patterns. Details of stratigraphic correlation and structural features of this area are still under investigation.

\subsection{Soils and Vegetation Within the SNL/KAFB Region}

Soils are classified according to a system designed to make it easier to remember significant soil characteristics and to see the relationships of soils to one another and to the entire environment (Soil Survey Staff 1975, 1981). The system of soils classification used by Hacker (1977) is that of the National Cooperative Soil Survey (USDA 1960). Certain features of this classification have been revised in more recent usage. The system of classification has six categories. Beginning with the broadest, these categories are order, suborder, great group, subgroup, family, and series. The criteria for classification are soil properties that can be observed in the field or that can be inferred either from other observable properties or from the combined data of soil science and other disciplines. The properties selected for high categories are those that affect soil genesis or are the result of soil genesis. See textbooks on soils science, such as Buol et al. (1989), for a description of soil genesis and taxonomy.

The classification scheme of Brown (1982) has been used for vegetation in this report. In general, lower elevations in the western portion of the SNL/KAFB area are dominated by grasslands with species such as black grama, blue grama, and western wheatgrass. In higher elevations in the eastern portion of SNL/KAFB, woodland communities prosper with species such as ponderosa pine, pinyon pine, and oneseed juniper. Various riparian species are found along the modern, active drainages.

\subsubsection{Soils}

The Albuquerque Basin extends from the gently sloping axial valley area near the Rio Grande to the steep-sloping piedmont adjacent to the Manzano and Sandia Mountains. Welldrained, loamy soils dominate throughout the region, with minor amounts of gravelly and stony soils along the arroyos and on the mountains. The dominant soil for a geographic area 
is shown in Figure 3-6. Minor amounts, typically less than 30 percent, of other soils are present within each of the dominant map units on the figure.

Thirteen distinct soil associations are recognized by Hacker (1977) for Bernalillo County and parts of Sandoval and Valencia counties, New Mexico (see Table 3-1). Table 3-2 shows the classification for soils in the SNL/KAFB region. The majority of moderately to welldeveloped soils are aridisols (typical of deserts) and mollisols (typical of savannas or grasslands). Relatively young soils with only minor soil development include entisols.

Table 3-1

Soil Associations in the SNL/KAFB Region (From Hacker 1977)

Deep soils on flood plains and dissected terraces:

1. Gila-Vinton-Brazito Association.

2. Bluepoint-Kokan Association.

3. Hantz-Gila Association.

Deeps soils on alluvial fans, mesas, and piedmonts:

4. Madurez-Wink Association.

5. Tijeras-Embudo Association.

6. Latene-Nickel Association.

Moderately deep or shallow soils on basalt flows:

7. Alemeda-Akela Association.

Very shallow to deep soils on uplands:

8. Penistaja-Travessilla-Bond Association.

9. Penistaja-Otero Association.

10. Shingle-Kim Association.

11. Silver-Witt-Laporte Association.

Shallow to deep soils on mountains and footslopes:

12. Seis-Orthids Association.

13. Kolob-Rock Outcrop Association. 


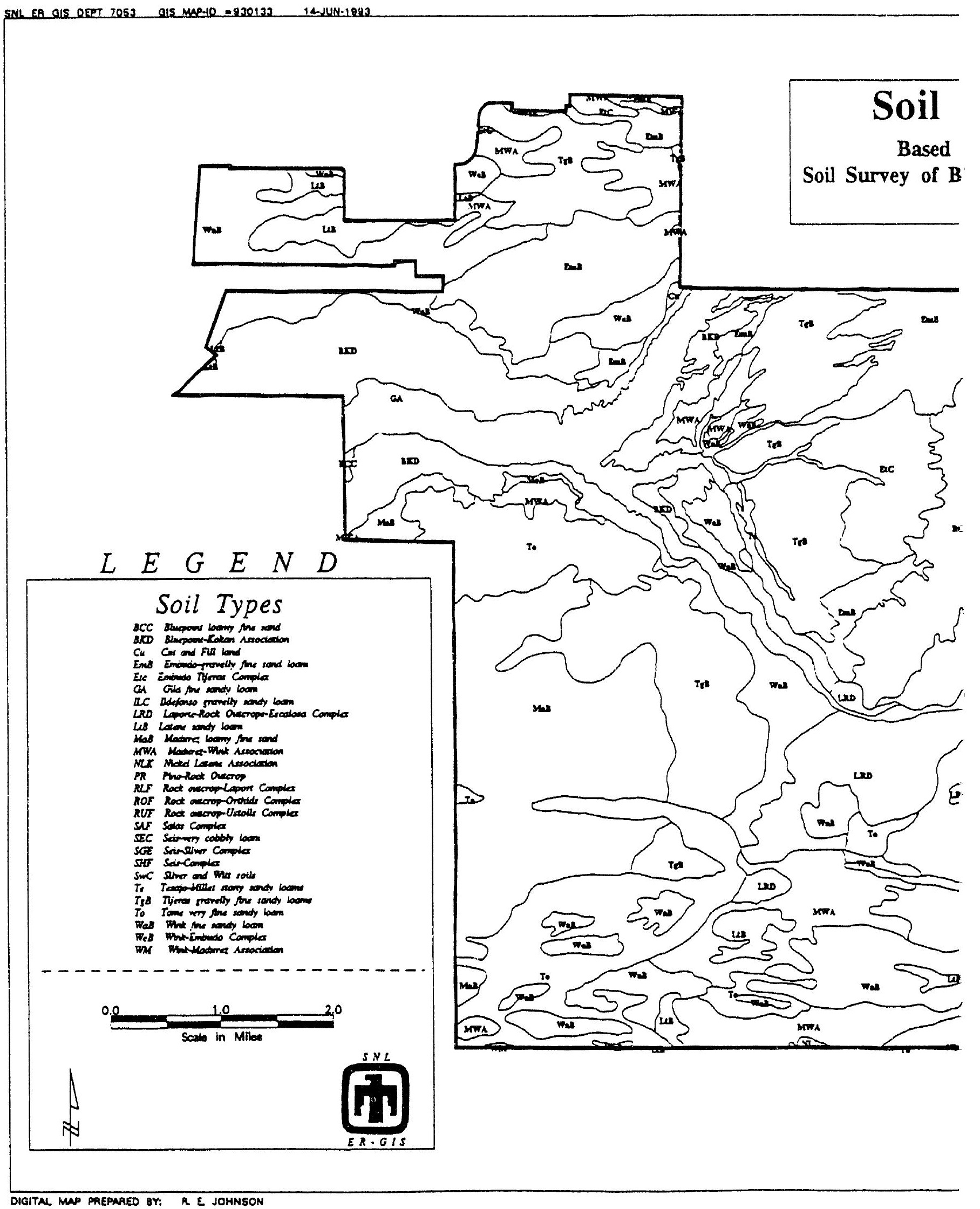

Figure 3-6. Generalized Soils Classification Geographic Information System. 


\section{Гypes in the SNL/KAFB Area}

in Data from U.S.D.A., Soil Conservation Service Report: rnalillo County and Parts of Sandoval and Valencia Counties, NM June, 1977

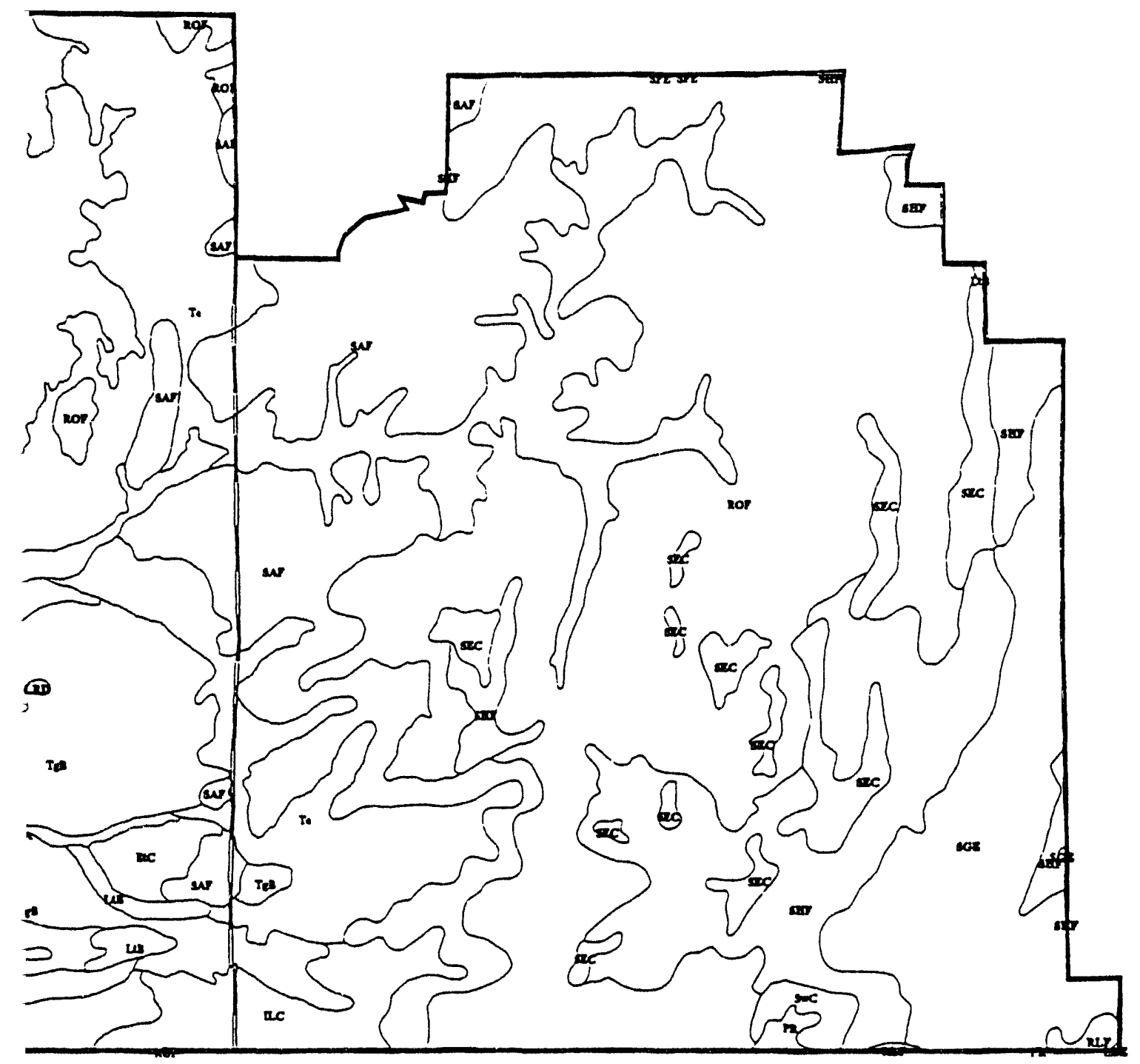

for SNL/KAFB (From SNL Department 7723 
Table 3-2

Classification of Soils in the SNL/KAFB Region (From Hacker 1977)

\begin{tabular}{|c|c|c|c|}
\hline SERIES & FAMILY & SUBGROUP & ORDER \\
\hline Agua & $\begin{array}{l}\text { Coarse-loamy over sandy or sandy-skeletal, } \\
\text { mixed (calcareous), thermic }\end{array}$ & Typic Torrifluvents & Entisols \\
\hline Agua variant & $\begin{array}{l}\text { Coarse-loamy over sandy or sandy-skeletal, } \\
\text { mixed (calcareous), thermic }\end{array}$ & Aquic Ustifluvents & Entisols \\
\hline Akela & Loamy-skeletal, mixed (calcareous), thermic & Lithic Torriorthents & Entisols \\
\hline Alemeda & Loamy-skeletal, mixed, thermic & Typic Calciorthids & Aridisols \\
\hline Anapra $^{1}$ & Fine, montmorillonitic, thermic & Typic Torrerts & Vertisols \\
\hline Bluepoint ${ }^{2}$ & Mixed, thermic & Typic Torripsamments & Entisols \\
\hline Bond & Loamy, mixed, mesic & Lithic Ustollic Haplargids & Aridisols \\
\hline Brazito & Mixed, thermic & Typic Torripsamments & Entisols \\
\hline Burnac & Fine, montmorillonitic & Mollic Eutroboralfs & Alfisols \\
\hline Carlito & Fine, mixed, mesic & Ustollic Haplargids & Aridisols \\
\hline Embudo & Coarse-loamy, mixed, nonacid, thermic & Typic Torriorthents & Entisols \\
\hline Escabosa & Fine-loamy, mixed, mesic & Aridic Calciustalls & Mollisols \\
\hline Gila $^{2,3}$ & Coarse-loamy, mixed (calcareous), mesic & Typic Torrifluvents & Entisols \\
\hline Glendale & Fine-silty, mixed (calcareous), thermic & Typic Torrifluvents & Entisols \\
\hline Hantz $z^{2}$ & Fine, mixed (calcareous), thermic & Typic Torrifluvents & Entisols \\
\hline Ildefonzo & Loamy-skeletal, mixed, mesic & Ustollic Calciorthids & Aridisols \\
\hline Kim & Fine-loamy, mixed (calcareous), mesic & Ustic Torriorthents & Entisols \\
\hline Kokan ${ }^{2}$ & Sandy-skeletal, mixed, thermic & Typic Torriorthents & Entisols \\
\hline Kolob & Clayey-skeletal, montmorillonitic & Typic Argiborolls & Mollisols \\
\hline Kolob variant & Clayey-skeletal, mixed & Argic Cryoborolls & Mollisols \\
\hline La Fonda & Fine-loamy, mixed, mesic & Ustollic Camborthids & Aridisols \\
\hline Laporte & Loamy, mixed, mesic & Lithic Haplustolls & Mollisols \\
\hline Latene & Coarse-loamy, mixed, thermic & Typic Calciorthids & Aridisols \\
\hline Madurez $^{4}$ & Fine-loamy, mixed, thermic & Typic Haplargids & Aridisols \\
\hline Manzano & Fine-loamy, mixed, mesic & Cumulic Haplustolls & Mollisols \\
\hline Millett & Fine-loamy, mixed, mesic & Ustollic Haplargids & Aridisols \\
\hline Nickel & Loamy, skeletal, mixed, thermic & Typic Calciorthids & Aridisols \\
\hline Otero & Coarse-loamy, mixed (calcareous), mesic & Ustic Torriorthents & Entisols \\
\hline
\end{tabular}


Table 3-2

Classification of Soils in the SNL/KAFB Region (From Hacker 1977) (Concluded)

\begin{tabular}{||llll||}
\hline SERIES & \multicolumn{1}{c}{ FAMILY } & \multicolumn{1}{c|}{ SUBGROUP } & ORDER \\
\hline Pajarito & Coarse-loamy, mixed, thermic & Typic Camborthids & Aridisols \\
Penistaja $^{5}$ & Fine-loamy, mixed, mesic & Ustollic Haplargids & Aridisols \\
Pino $^{6}$ & Fine, mixed & Typic Argiborolls & Mollisols \\
Salas & Loamy, skeletal, mixed, mesic & Aridic Argiustolls & Mollisols \\
Sandia & Loamy, skeletal, mixed & Typic Haploborolls & Aridisols \\
Scholle & Fine-loamy, mixed, mesic & Ustollic Halpargids & Aridisols \\
Seis & Loamy-skeletal, mixed, mesic & Ustollic Calciorthids & Aridisols \\
Shingle & Loamy, mixed (calcareous), mesic shallow & Ustic Torriorthents & Entisols \\
Silver & Fine, mixed, mesic & Ustollic Haplargids & Aridisols \\
Tesajo & Loamy-skeletal, mixed, mesic & Cumulic Haplustalls & Mollisols \\
Tijeras & Fine-loamy, mixed, thermic & Typic Haplargids & Aridisols \\
Tome & Fine-silty, mixed (calcareous), thermic & Typic Torriorthents & Entisols \\
Travessilla & Loamy, mixed (calcareous), mesic & Lithic Ustic Torriorthents & Entisols \\
Vinton & Sandy, mixed, thermic & Typic Torrifluvents & Entisols \\
Wink & Coarse-loamy, mixed, thermic & Typic Calciorthids & Aridisols \\
Witt & Fine-silty, mixed, mesic & Ustollic Haplargids & Aridisols \\
\hline \hline
\end{tabular}

1. Some soils are taxadjuncts to the series because they have hue of $5 Y R$.

2. Some soils are taxadjuncts to their respective series because their annual temperature is a few degrees cooler than is defined as the range for the series.

3. Some soils are taxadjuncts to the series because they are 18 to 24 percent clay, which is more than is defined as the range for the series.

4. Some soils are taxadjuncts to the series because they have a Cca (Bk) horizon that has less lime than is defined as the range for the series.

5. Some soils are taxadjuncts to the series because they are coarser textured than is defined as the range for the series.

6. Some soils are taxadjuncts to the series because their annual temperature is a few degrees warmer than is defined for the series. 


\subsubsection{Vegetation}

Four biomes are recognized for SNL/KAFB based on the classification scheme of Brown (1982) (see Table 3-3). Lower elevations in the western portion of the area are dominated by grasslands, with species such as black grama, blue grama, and western wheatgrass locally constituting 30 to 40 percent of the vegetative mass. In higher elevations in the Manzanita Mountains, woodland communities prosper with species such as ponderosa pine, pinyon pine, and oneseed juniper. As should be expected, a close association is seen between different soils, vegetation, elevation, and precipitation. These relationships are summarized in Table 3-3. Distribution of the vegetation types found on SNL/KAFB are shown in Figure 3-7.

\subsection{Hydrogeologic Framework}

Because few deep boreholes have been drilled within the SNL/NM region and because the distribution of subsurface geologic data is sparse, the subsurface hydrogeology of the SNL/KAFB site is, at present, poorly defined. Hawley and Haase (1992) developed a hydrogeologic $\mathrm{CM}$ for the Bernalillo County area of the east-central Albuquerque Basin that provides the basis for the development of an SNL/KAFB-specific model. This area-specific $\mathrm{CM}$ is in the incipient stage of development and considers both vadose zone and saturated zone hydrologic and transport issues.

The hydrogeologic framework across SNL/KAFB is defined by structural boundaries [e.g., the position of major structural features (see Section 3.2)] and the spatial distribution of hydrostratigraphic units, lithotypes [i.e., "lithofacies" of Hawley and Haase (1992)], and interlithotype heterogeneity. Currently, little is known about the spatial distribution of these parameters across SNL/KAFB. In the following sections, the hydrostratigraphy and lithofacies relationships described by Hawley and Haase (1992) are summarized. These relationships provide the basis for future investigations of the hydrogeologic framework of the SNL/KAFB site.

\subsubsection{Hydrostratigraphy}

Hawley and Haase (1992) propose six hydrostratigraphic subdivisions of the Albuquerque Basin in the Albuquerque metropolitan area. These hydrostratigraphic units are conceptually equivalent to rock-stratigraphic units of formational rank. The Santa Fe Group, the basin-fill unit of the Rio Grande Rift (Figure 3-8), is subdivided into upper, middle, and lower units. Alluvial deposits within the basin are subdivided into valley-border alluvium (VA), piedmontslope alluvium (PA), and river alluvium (RA).

The lower Santa Fe (LSF) unit (Figure 3-9) consists of up to 3,500 ft (1,067 m) of sandstone, conglomeritic sandstone, and gypsiferous mudstone (Hawley and Haase 1992). The age of these deposits is between about 30 and $15 \mathrm{Ma}$. The distribution of sediment types within the LSF unit reflects deposition in an internally draining basin of limited relief and structural definition. The basin margins are characterized by fan and coalescent fan alluvium, whereas playa sediments and playa-margin alluvium are present in the basin center. 
Table 3-3

Relationships of Soil Series and Vegetation in the SNL/KAFB Area

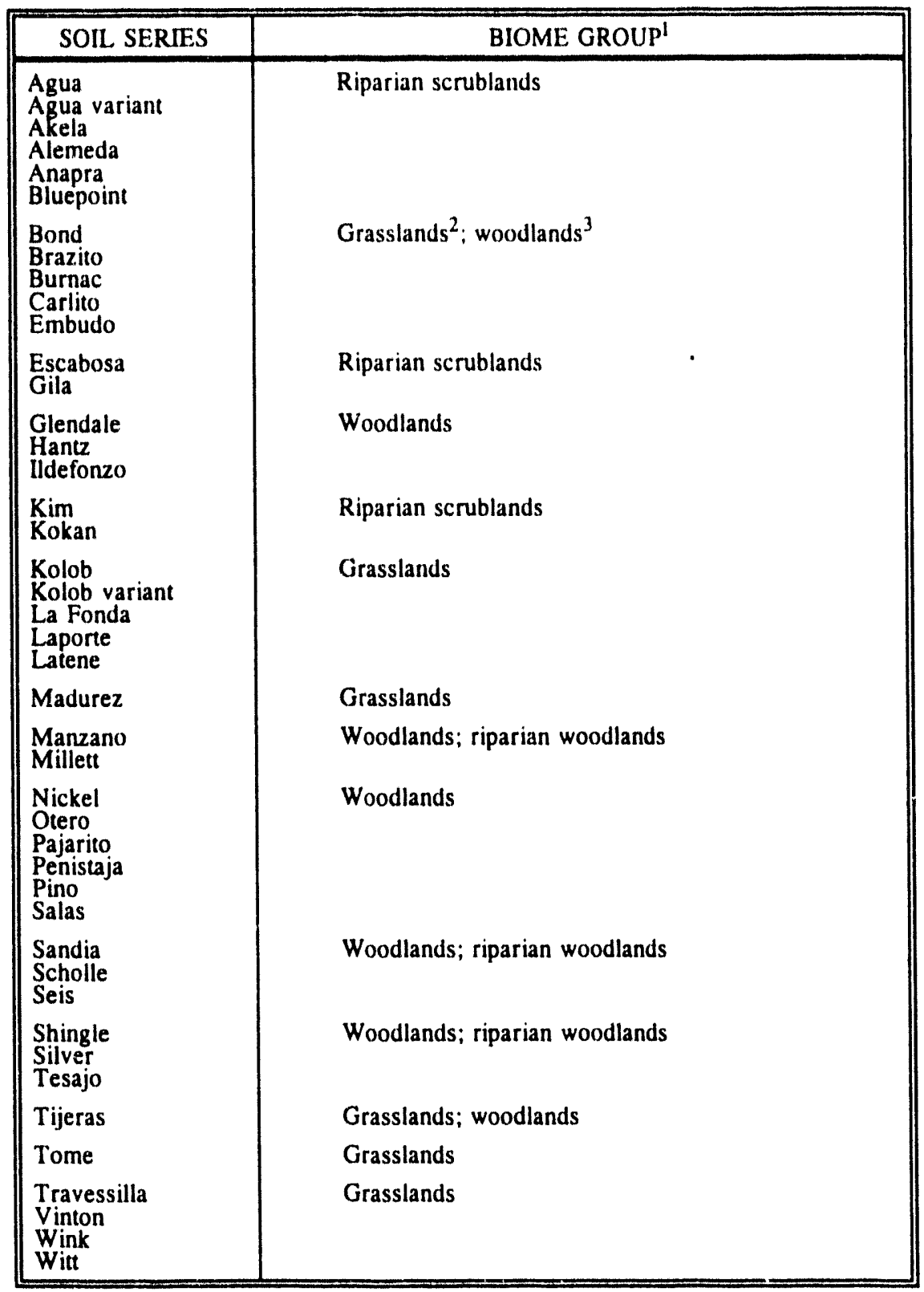

1. Hierarchical system for the classification of biomes is that of Brown (1982).

2. Grasslands vegetation cover the lower alluvial slopes and terrace surfaces of the western half of SNL/KAFB. Three biomes influence the grasslands of SNL/KAFB: the Great Basin Grassland, Semidesert Grassland, and Plains Grassland biomes of Brown (1982).

3. Woodland vegetation zones occur in the upper alluvial slopes and in the mountainous areas in the eastern half of SNL/KAFB. Three biomes influence the composition of the woodlands: the Great Basin Conifer Woodland, Great Basin Montane Scrubland, and Rocky Mountain Montane Conifer Forest biomes of Brown (1982). 


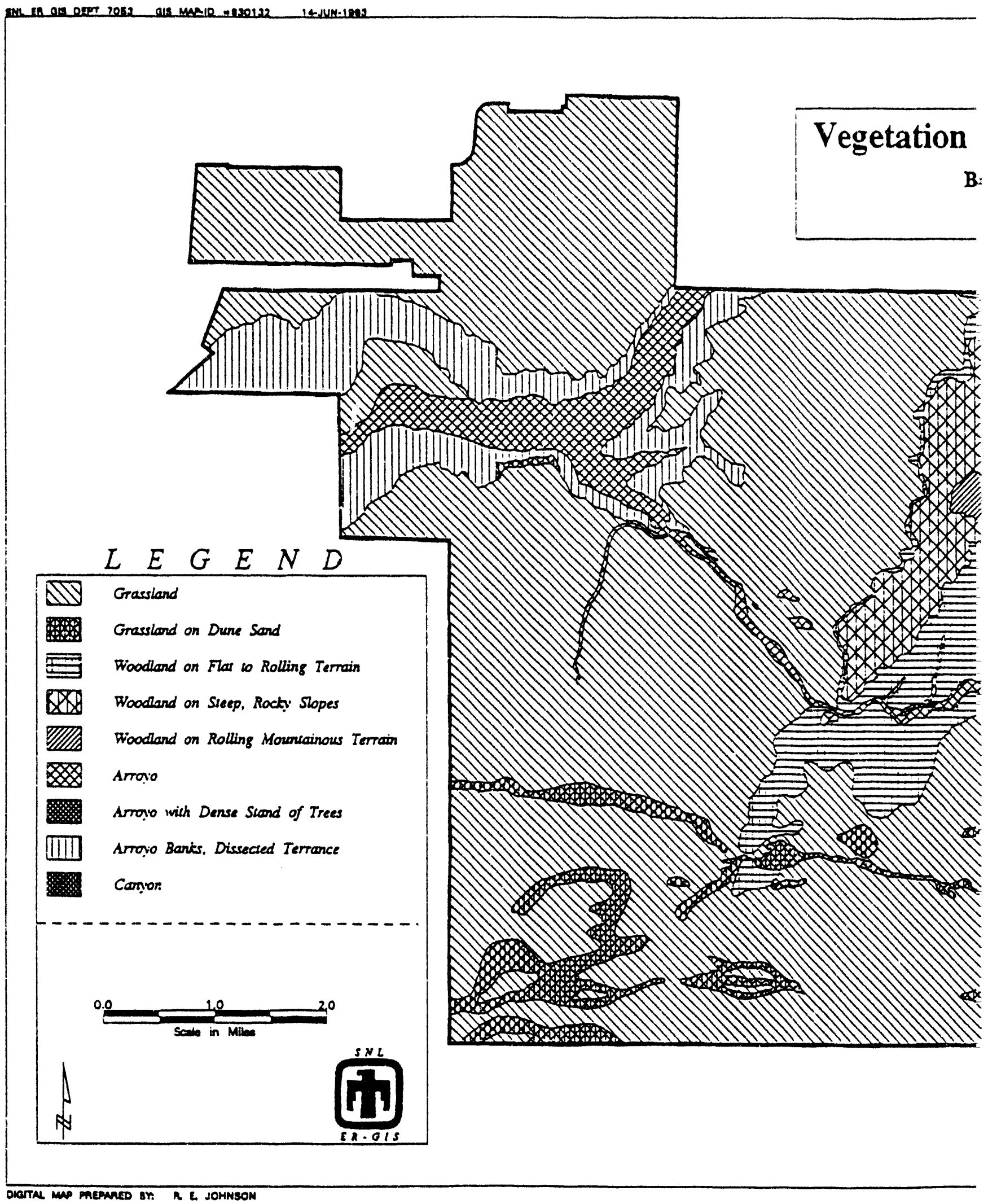

Figure 3-7. Generalized Vegetation Type Geographic Information Syste, 


\section{Cover Types in the SNL/KAFB Area}

sed on Survey by IT Corporation, May 1992 Ibuquerque Environmental Baseline Update

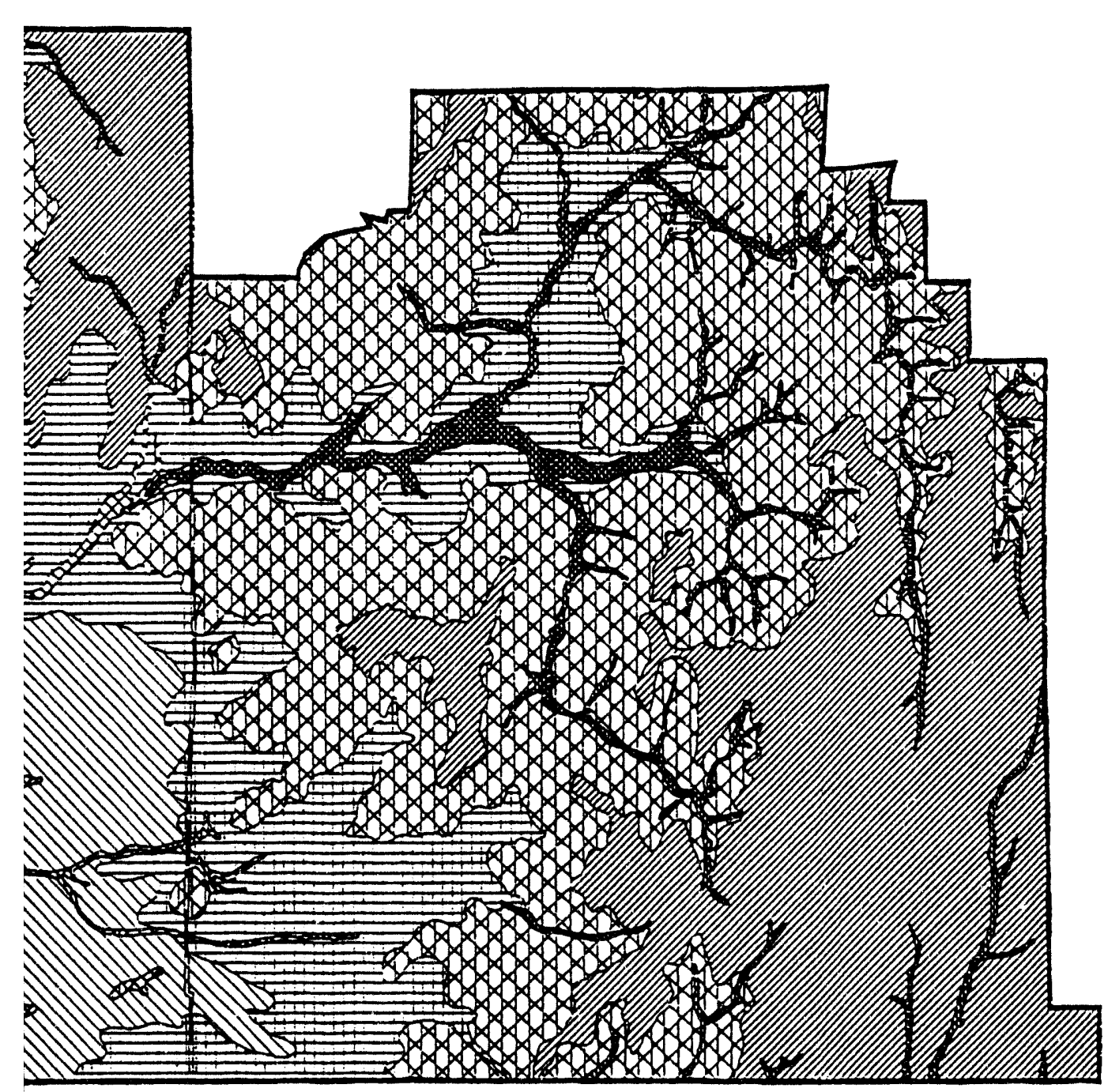

for SNL/KAFB (From SNL Department 7723 n) 


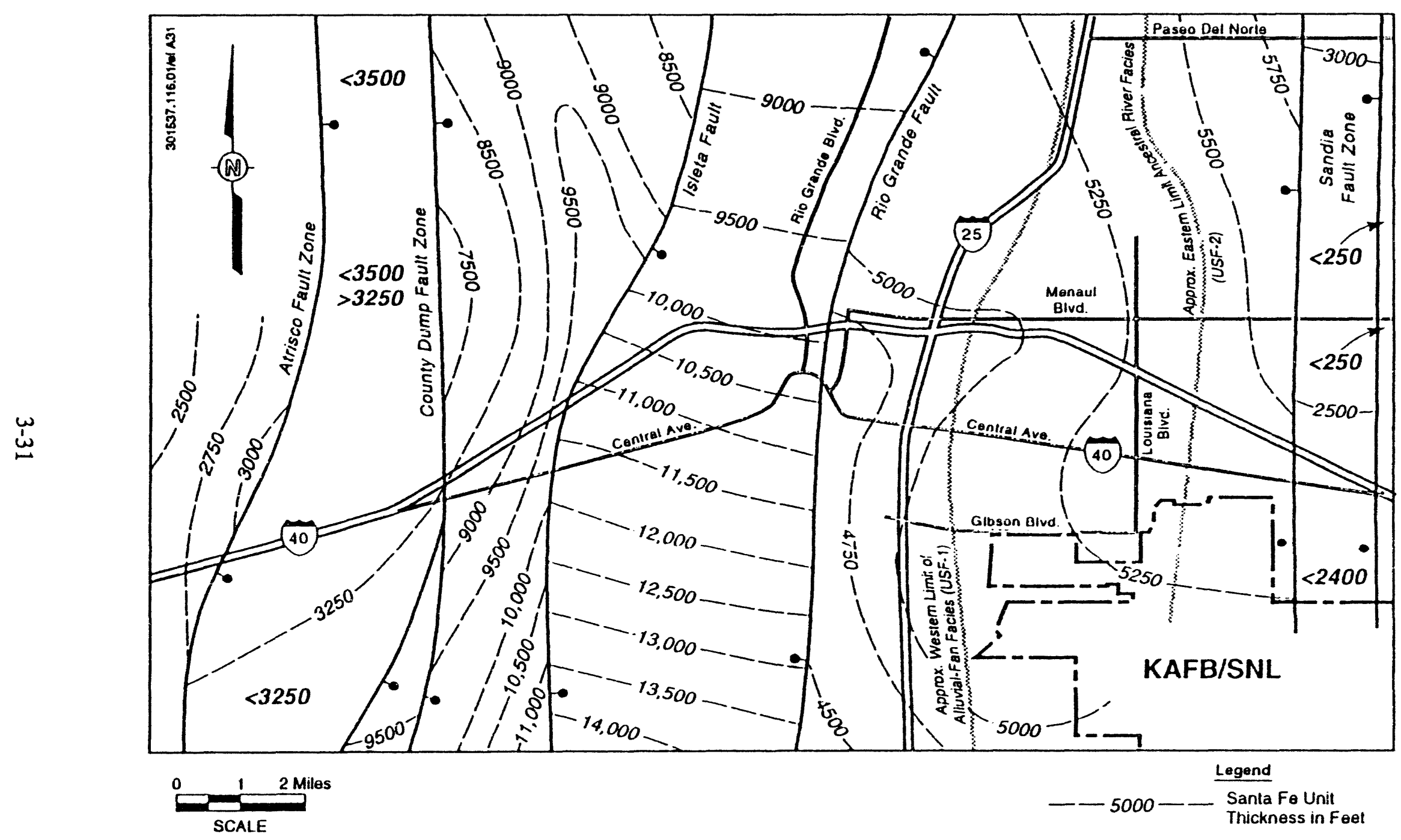

Figure 3-8. Isopach Map of the Entire Santa Fe Group in the Albuquerque Area (From Hawley and Haase 1992) 


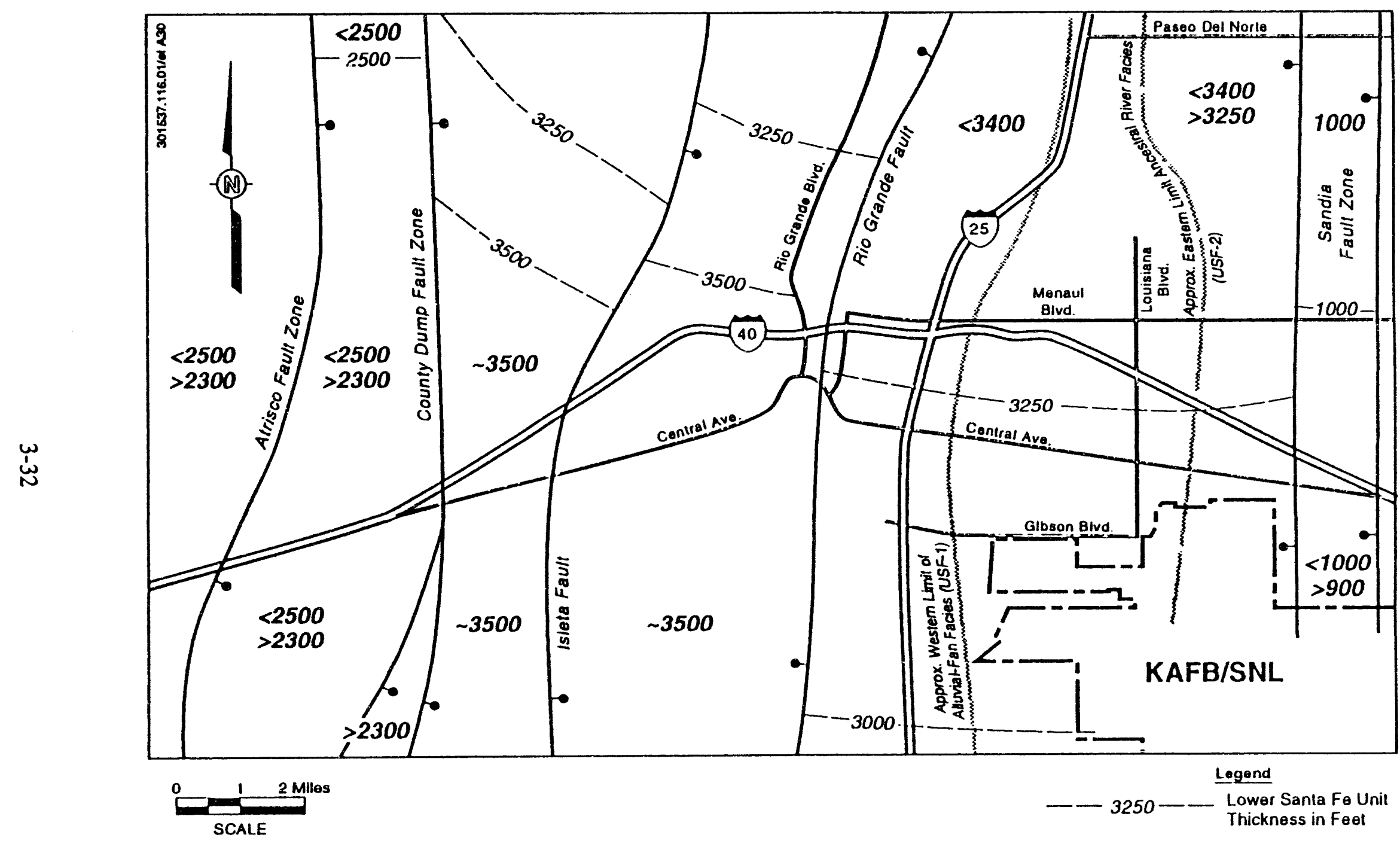

Figure 3-9. Isopach Map of the Lower Santa Fe Group in the Albuquerque Area (From Hawley and Haase 1992) 
The middle Santa Fe (MSF) unit (Figure 3-10) accumulated between about 15 and 5 Ma, when tectonic activity peaked in the basin (Hawley and Haase 1992). Alluvial fans continued to deposit coarse-grained material along the basin margins, although the sedimentation rates were higher due to increased tectonic activity. Major fluvial systems from the north, northeast, and southwest contributed additional clastic material to the basin floor. Stream systems emptied into a playa-lake complex in the southern part of the basin. The majority of the Santa Fe Group was deposited at this time [up to $10,000 \mathrm{ft}(3,049 \mathrm{~m})$ in the Isleta Pueblo Indian Reservation area].

Hawley and Haase (1992) subdivide the MSF unit into two subunits within the Albuquerque metropolitan area. Subunit MSF-1 consists of alluvial sand and conglomerate derived from the Sandia, Manzanita, and Manzano Uplifts and the ancestral Tijeras Canyon drainage. Subunit MSF-2 contains less coarse-grained material representing braided fluvial, eolian, and playa deposits. Along the margins of the basin, MSF-1 and MSF-2 display complex intertonguing relationships.

The upper Santa Fe unit (USF) (Figure 3-11), which ranges up to 1,200 $\mathrm{ft}(366 \mathrm{~m})$ in thickness (Hawley and Haase 1992), was deposited after about $5 \mathrm{Ma}$, when the throughflowing ancestral Rio Grande drainage system developed. Two eastward-flowing ancestral tributaries, the Rio San Jose and Rio Puerco, joined the ancestral Rio Grande, creating a large aggradational plain in the basin center. Cross-stratified, medium- to coarse-grained sand and pebbly sand accumulated within fluvial channel areas, whereas muds were deposited in distal channel areas. Alluvial fans continued to deposit poorly sorted sand and conglomerate along the fault-bounded eastern margin of the basin. Distal fan environments interacted with fluvial environments, producing complex marginal relationships. Locally and distally derived volcanic materials were deposited episodically within the basin, and, in local areas, wind-blown sand and silt accumulated.

Hawley and Haase (1992) subdivide the USF unit into three subunits. Subunit USF-1 consists of coarse-grained alluvial fan and piedmont-veneer deposits, extending west from the Sandia, Manzanita, and Manzano Uplifts. Subunit USF-2 contains ancestral Rio Grande deposits and other fine-grained basin fill. Subunit USF-3 includes the alluvial and eolian deposits capping the Llano de Albuquerque, a tableland that lies between the Rio Grande and the Rio Puerco in the central portion of the Albuquerque Basin.

Alluvial deposits within the Albuquerque Basin are subdivided by Hawley and Haase (1992) into three hydrostratigraphic units (Figure 3-12). The RA consists of channel and floodplain deposits in the Rio Grande and Rio Puerco valleys. The RA unit might be as much as $120 \mathrm{ft}$ $(36.6 \mathrm{~m})$ thick. The VA unit contains up to $200 \mathrm{ft}(61 \mathrm{~m})$ of tributary arroyo and thin eolian deposits in areas bordering the inner Rio Grande and Rio Puerco valleys. The VA includes fan, terrace, and channel deposits. The PA includes coalescing alluvial fan deposits and surficial deposits that mantle piedmont geomorphic surfaces. The PA deposits are up to $150 \mathrm{ft}(45.7 \mathrm{~m})$ thick.

\subsubsection{Lithofacies}

Based on sediment texture, degree of induration, geometry of bodies, and distribution patterns of zones of contrasting texture, Hawley and Haase (1992) define ten material categories, or lithofacies, for the sediments contained within the Albuquerque Basin. The lithofacies' subdivisions and their categories are defined in Table 3-4; a hypothetical distribution of these units is shown in Figure 3-13. Lithofacies I to VI are unconsolidated or 


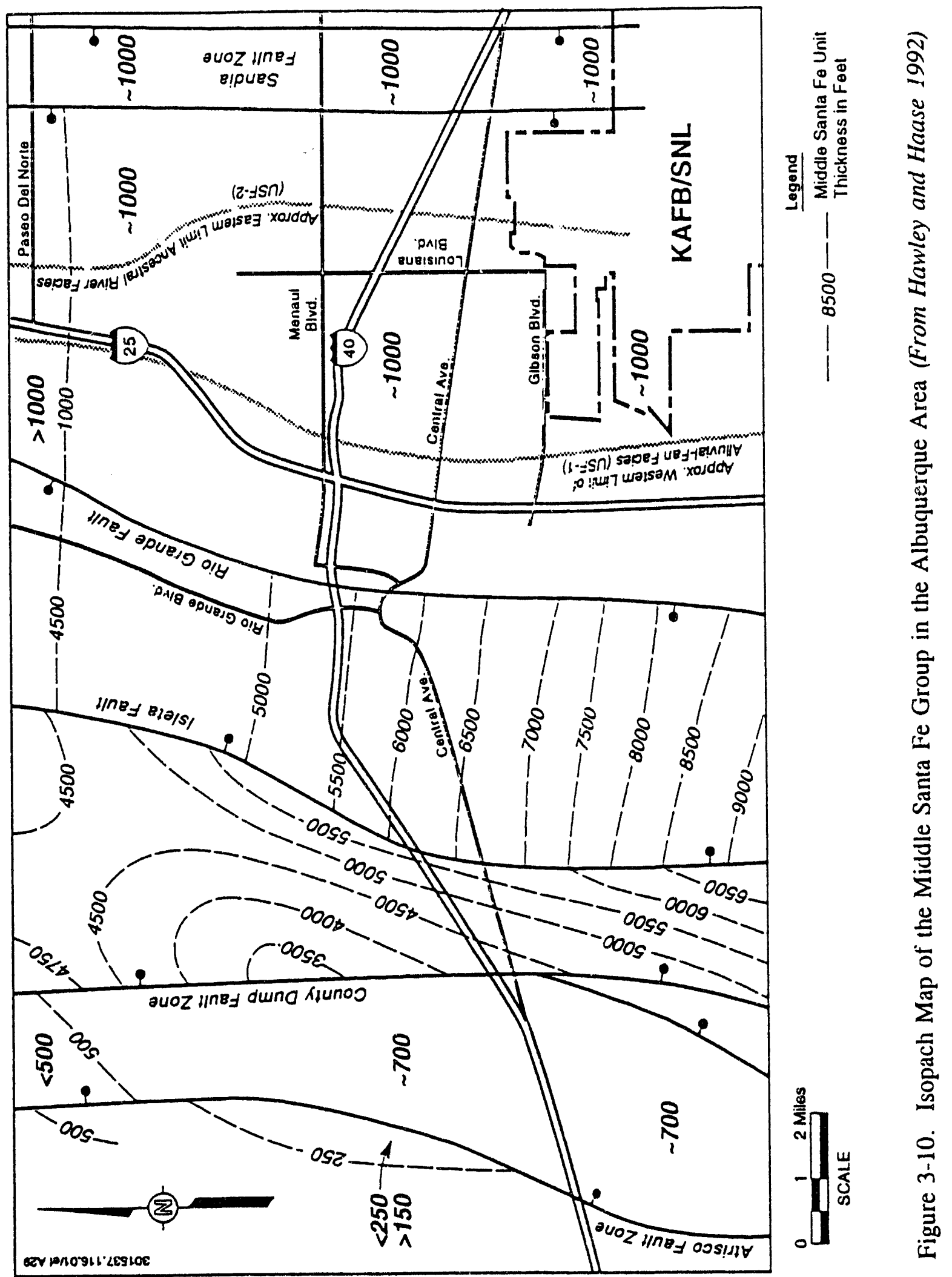




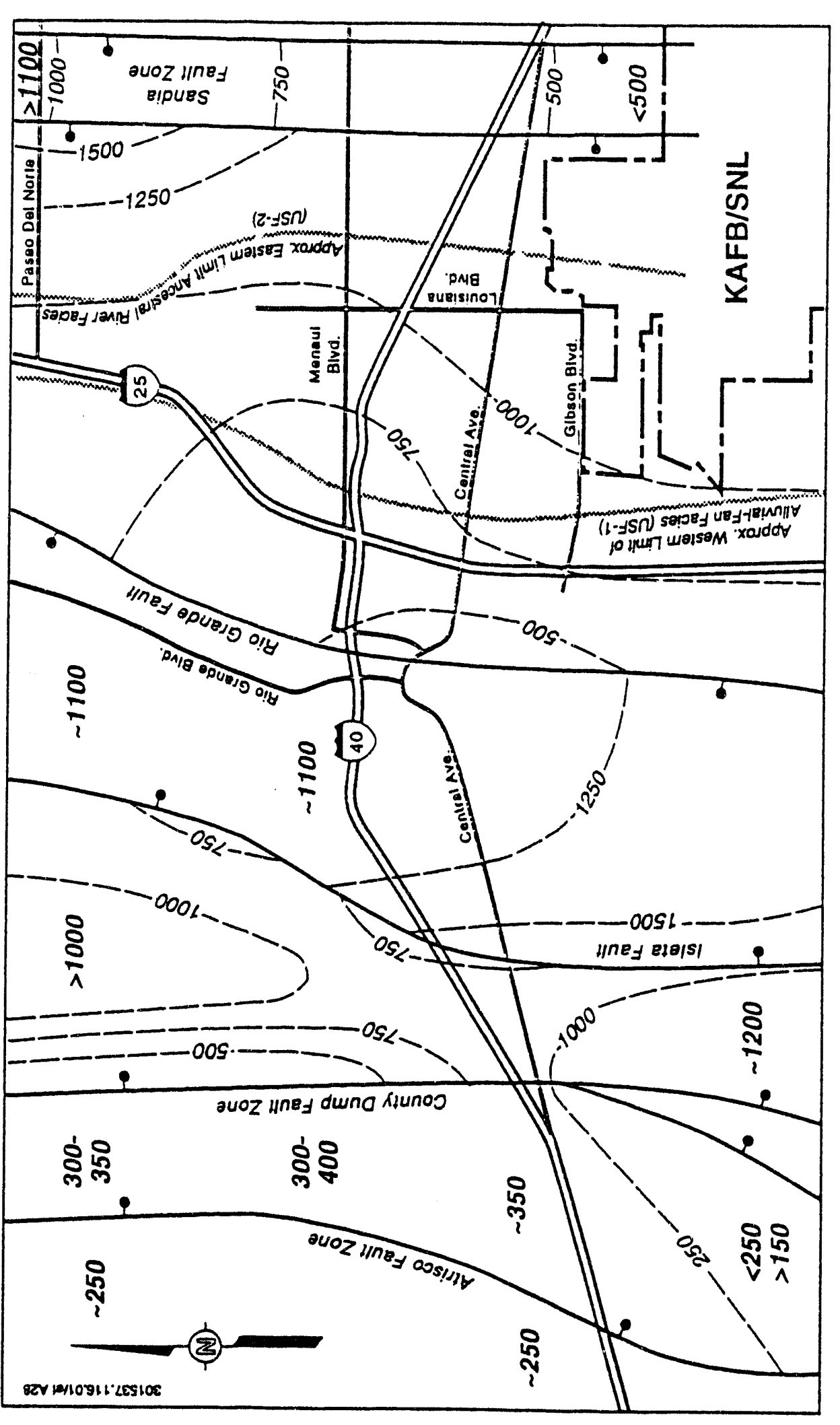

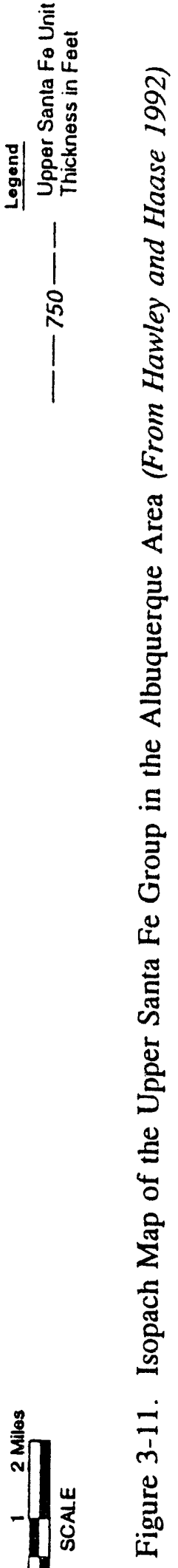




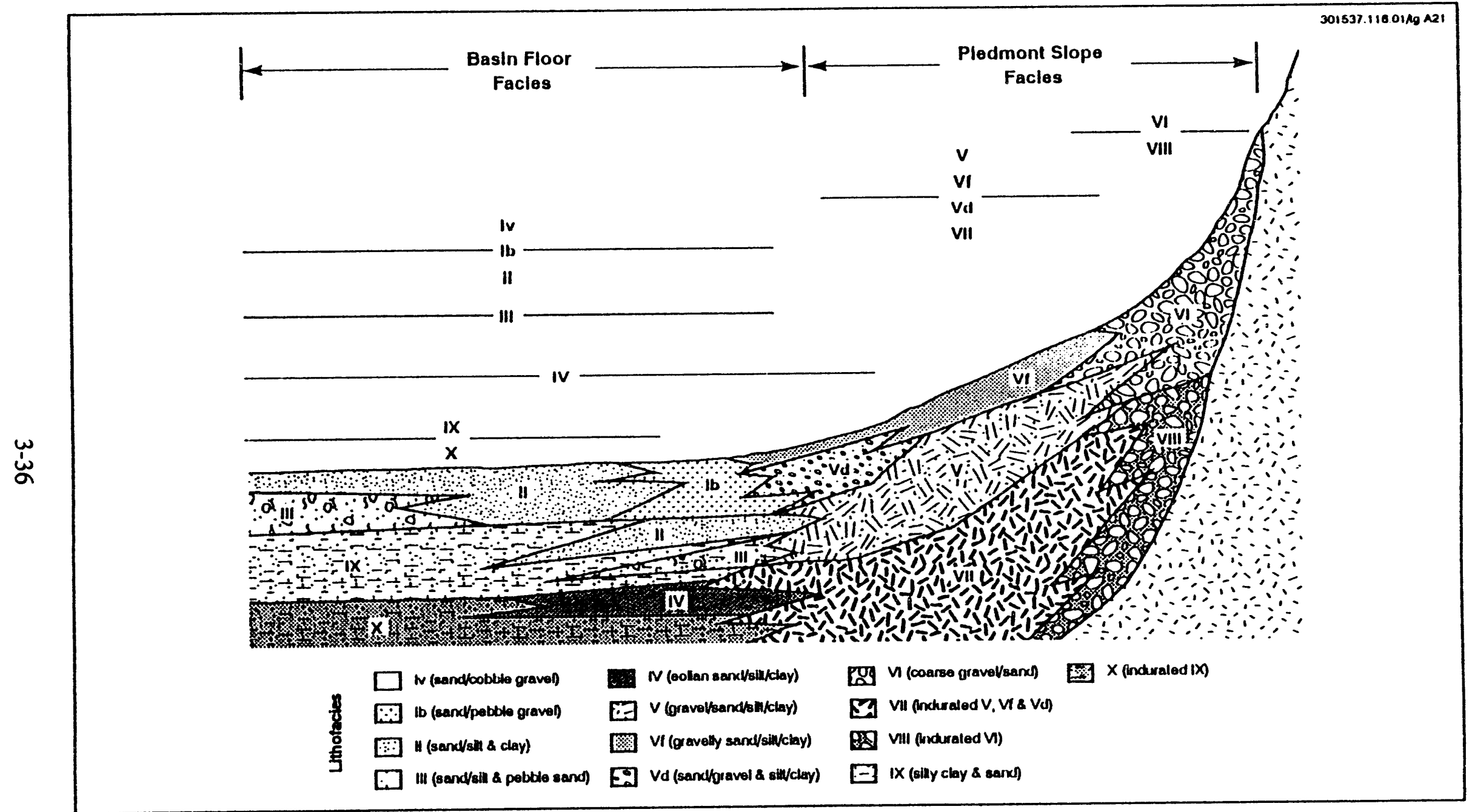

Figure 3-12. Hypothetical Distribution of Hydrostratigraphic Units in the Albuquerque Basin (Units are described in the text; from Hawley and Haase 1992) 
Table 3-4

Summary of Lithofacies' Compositions and Depositional Settings Used in Figure 3-13

(From Hawley and Haase 1992)

\begin{tabular}{|c|c|c|}
\hline $\begin{array}{l}\text { LITHOFACIES } \\
\text { DESIGNATION } \\
\end{array}$ & COMPOSITION & DEPOSITIONAL SETTING \\
\hline Iv & Sand and pebble to cobble gravel & River valley and basin-floor fluvial \\
\hline Ib & Sand and pebble gravel; lenses of silt and silty clay & River valley and basin-floor fluvial; braided streams \\
\hline $\mathbf{I}$ & Cobble to pebble gravel, sand, silt, and silty clay & Undifferentiated fluvial \\
\hline II & Sand; lenses of pebbly sand, silt, and silty clay & Basin-floor fluvial; locally eolian \\
\hline III & Interbedded sand, silt, and silty clay; lenses of pebbly sand & Basin-floor alluvial and playa lake; locally eolian \\
\hline IV & Sand and silt; lenses of silty clay and clay & Basin-floor eolian and distal piedmont alluvial fan \\
\hline Vv & Sand, silt, silty clay, and gravel (not shown) & Arroyo and river-valley border alluvial \\
\hline Vf & $\begin{array}{l}\text { Gravelly sand, silt, and clay; lenses of sand, gravel, and silty } \\
\text { clay }\end{array}$ & $\begin{array}{l}\text { Distal to medial piedmont-slope alluvial fan associated with small } \\
\text { watersheds; alluvial-fan distributary channel and debris flow }\end{array}$ \\
\hline Vd & $\begin{array}{l}\text { Sand and gravel; lenses of gravelly to nongravelly sand, silt, } \\
\text { and clay }\end{array}$ & $\begin{array}{l}\text { Distal to medial piedmont-slope alluvial fan associated with large } \\
\text { watersheds; alluvial-fan distributary channel }\end{array}$ \\
\hline $\mathrm{v}$ & Gravel, sand, silt, silty clay, and clay & Undifferentiated distal to medial piedmont-slope alluvial fan \\
\hline VI, VIf, VId & $\begin{array}{l}\text { Coarse gravelly sand, silt, and clay; lenses of sand and gravel; } \\
\text { cobbles and boulders }\end{array}$ & $\begin{array}{l}\text { Proximal to medial piedmont-slope alluvial fan; debris flow; } \\
\text { distributary channel }\end{array}$ \\
\hline VII & $\begin{array}{l}\text { Gravel, sand, silt, and clay; indurated Vf and Vd; indurated V, } \\
\text { Vf, Vd, and Vv }\end{array}$ & $\begin{array}{l}\text { Distal to medial piedmont-slope alluvial fan; alluvial-fan } \\
\text { distributory channel and debris flow }\end{array}$ \\
\hline VIII & $\begin{array}{l}\text { Coarse gravelly sand, silt, and clay; lenses of sand and gravel; } \\
\text { cobbles; indurated VI, VIf, and VId }\end{array}$ & Proximal to medial piedmont-slope alluvial fan \\
\hline IX & Silty clay interbedded with silty sand, silty clay, and clay & Basin-floor playa lake and alluvial flat; distal piedmont alluvial \\
\hline $\mathrm{x}$ & $\begin{array}{l}\text { Silty clay interbedded with silty sand, silty clay, and clay; } \\
\text { indurated IX }\end{array}$ & Basin-floor playa lake and alluvial flat; distal piedmont alluvial \\
\hline
\end{tabular}




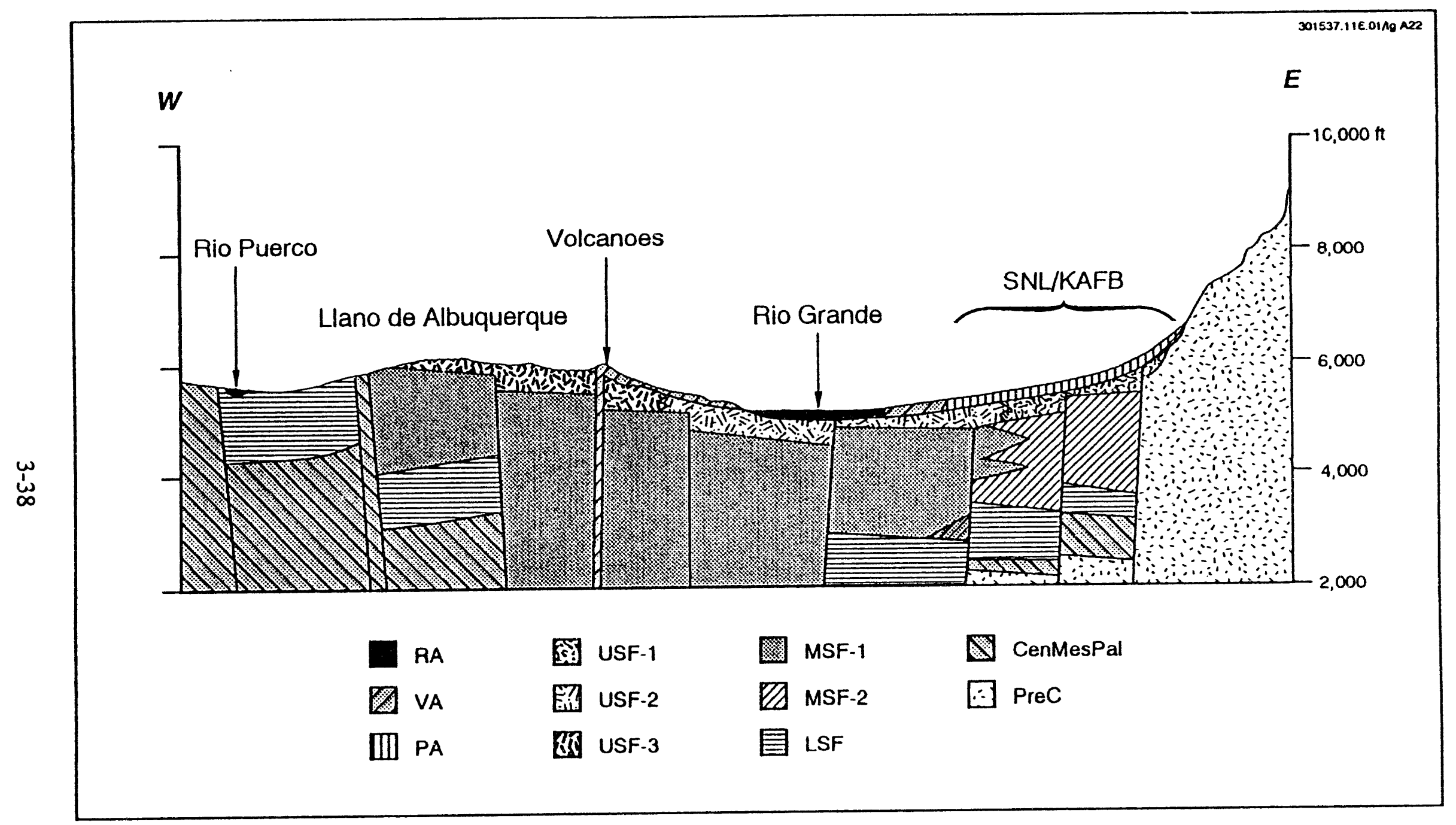

Figure 3-12. Hypothetical Distribution of Hydrostratigraphic Units in the Albuquerque Basin (Units are described in the text; from Hawley and Haase 1992) 
have discontinuous zones of induration. These units consist mostly of clean sand and gravel bodies with relatively high hydraulic conductivity. Lithol u ies VII to X are partly to well indurated and contain significant amounts of clay and silt as the primary component or as a matrix for a sand and gravel framework. The coarse-grained channel deposits of the modern and ancestral Rio Grande (lithofacies I and II) are the most important aquifer and potential recharge zones in the basin. The distributary channel deposits of the ancestral Tijeras Canyon fan (lithofacies Vd) also has a high aquifer potential. The distribution of these lithofacies along the northern and southern part of SNL/KAFB are shown in Figures 3-14 through 3-16.

\subsubsection{Hydrogeologic Regions at SNL/KAFB}

The SNL/KAFB area can be subdivided into three distinct hydrogeologic regions (HR) (Figure 3-17): (1) HR1 occupies the western part of the study area and is characterized by thick bolson fill; (2) HR2 occurs within the Tijeras/Hubbell Spring/Sandia Fault complex in the south-central part of SNL/KAFB and is characterized by complex depth-to-bedrock relationships; and (3) HR3 occurs east of the fault complex on Hubbell Bench and is characterized by shallow bedrock. Each of these regions is characterized by distinct bedrock relationships and lithofacies. The boundaries of each of these regions and their constituent materials are poorly defined across SNL/KAFB, in that geophysical data has only begun to define these boundaries, and little borehole information is currently available.

HR1 is the largest hydrologic region on SNL/NM (Figure 3-17). It occurs within the westernmost part of SNL/KAFB. The PA unit (lithofacies $V$ ) overlies most of the region. It is underlain by the USF-1 (lithofacies VI) in the east and USF-2 (lithofacies Ib-II) in the west. In the central part of the region, USF-1 and USF-2 interfinger, and the sequence consists of a complex mix of lithofacies Ib, II, V, Vd, and VI. The MSF unit underlies USF-1 and USF-2. In the western part of the region, the unit is undifferentiated. In the eastern part of the region, Hawley and Haase (1992) report MSF-1 associated with lithofacies Vd.

HR2 occurs in the southeastern part of SNL/NM and is bounded by thick basin fill to the west and Hubbell Bench to the east. This region is the most structurally complex area on SNL/KAFB and includes the Tijeras/Hubbell Spring/Sandia Fault complex, as well as other faults, as discussed in Section 3.2. The northern boundary of the region occurs at Travertine Hills, the approximate location where the three fault systems intersect. The depth to bedrock is quite variable across the region, reflecting a generally westward down-stepping series of faults. PA (lithofacies $\mathrm{V}$ ) occurs at the surface across most of the region. In the southern part of HR2, USF-1 crops out at the surface, and areas of eolian sand occur locally. In the western part of the region, USF-1 (lithofacies V to VI) occurs in the subsurface, whereas bedrock underlies PA in the east. The relationship between these zones is complex and poorly resolved.

HR3 is located on Hubbell Bench and is characterized by an irregular but shallow depth to bedrock [from 50 to $150 \mathrm{ft}(15.2$ to $45.7 \mathrm{~m})$ ]. The PA is the only hydrostratigraphic unit present in the region, although the bedrock material in this region is considered a potential aquifer system(s) because of its fractured nature. 


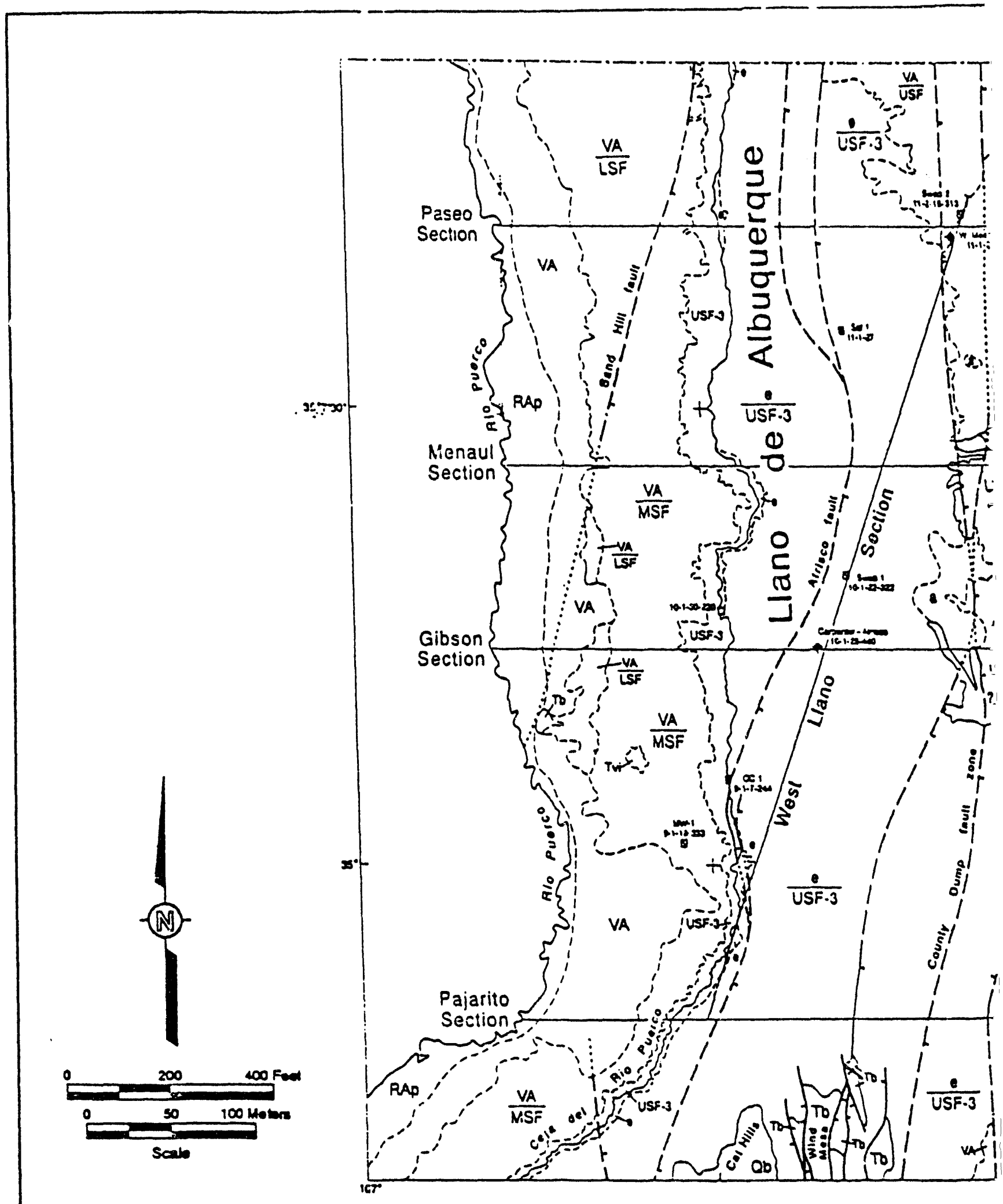

Figure 3-14. Hydrogeologic Map of $t$ Albuquerque Basin, New M cross sections in Figures 3-. section) are shown] 
301537.116018

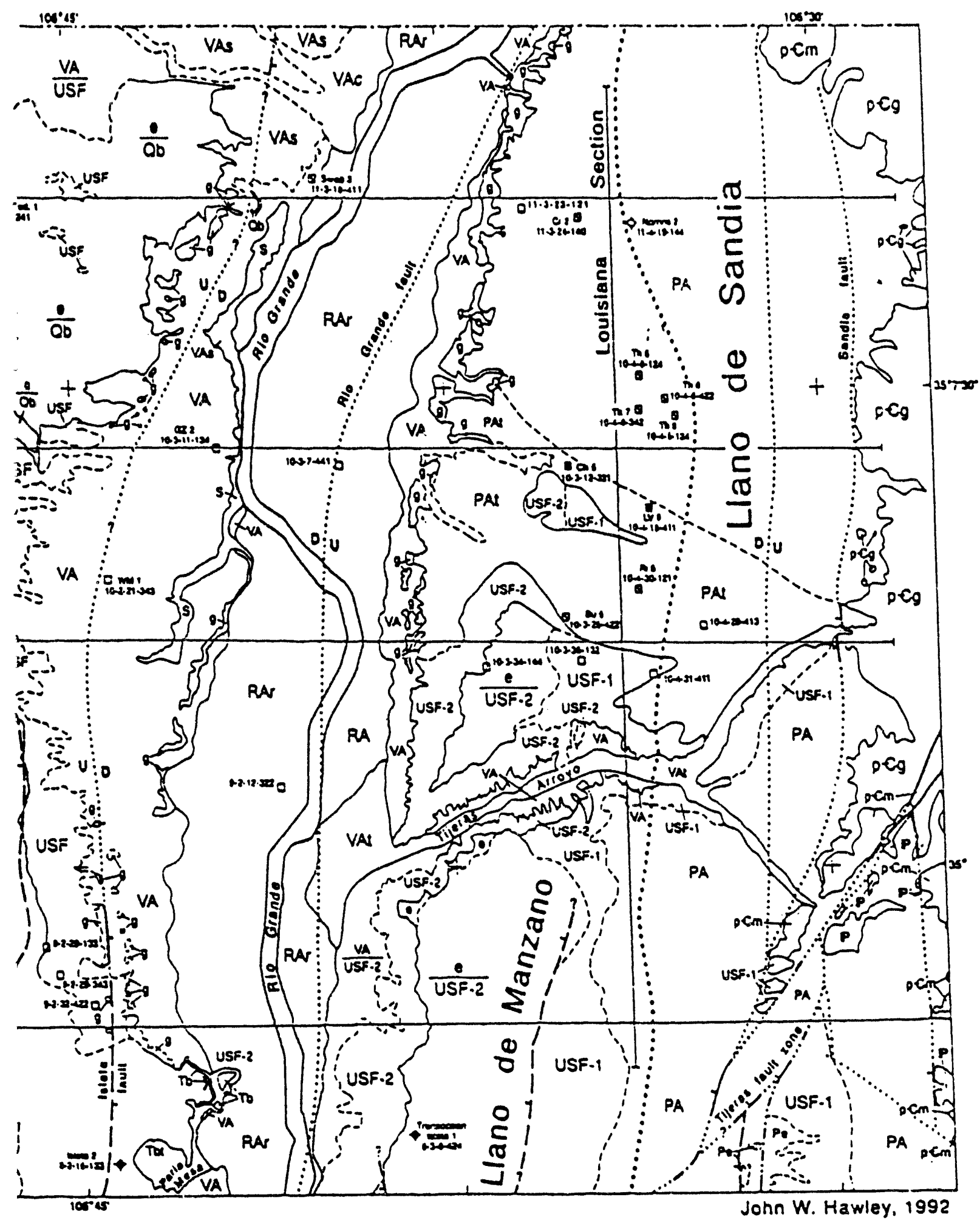

1e Albuquerque Metropolitan Area, Northern 3xico [From Hawley and Haase 1992; location of 5 (Gibson cross section) and 3-16 (Pajarito cross 


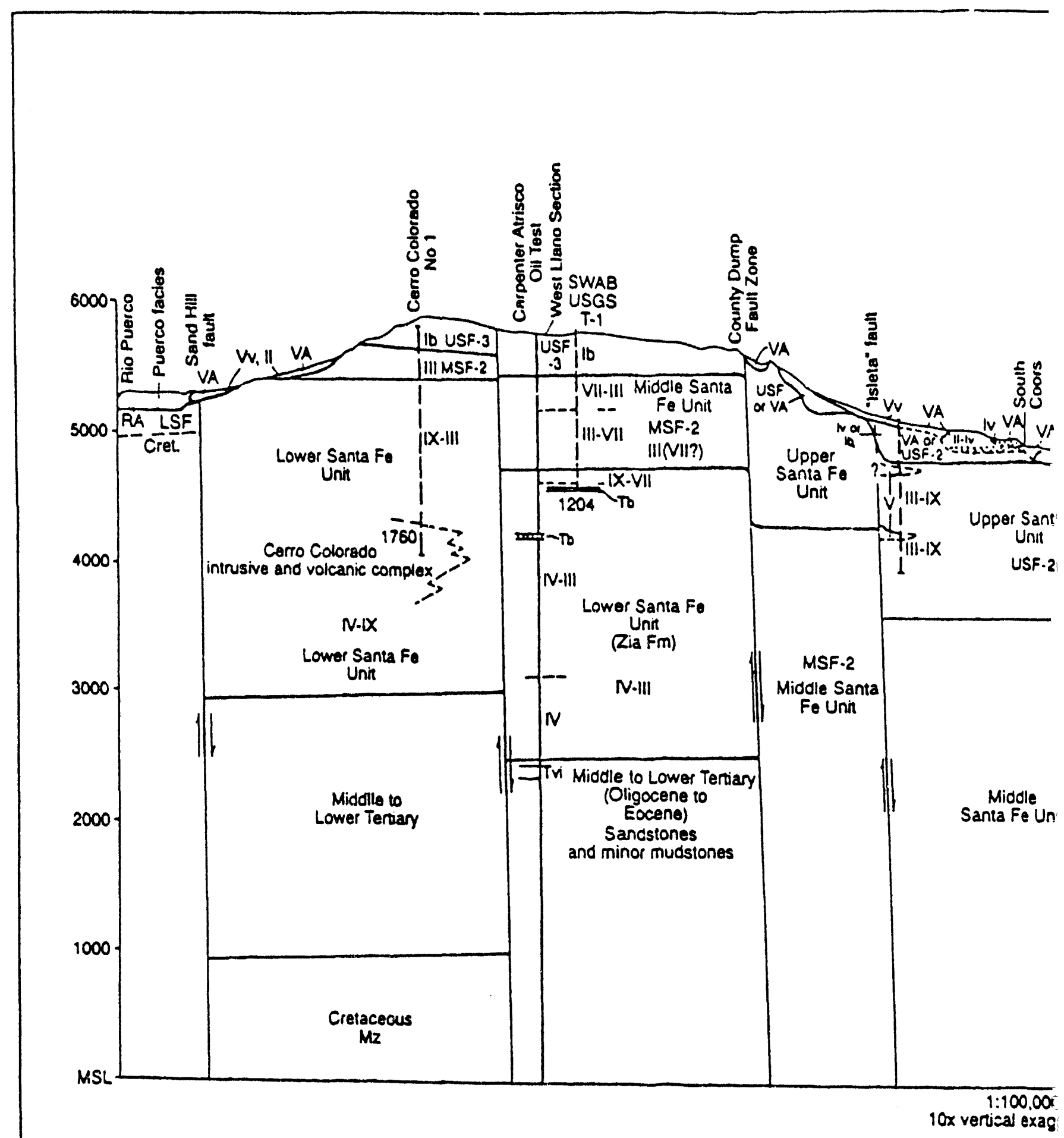

Figure 3-15. Gibson Hydrogeologic Cross $\mathrm{S}$ Hawley and Haase 1992; see I 
301537.116 .01 is

SNL/KAFB

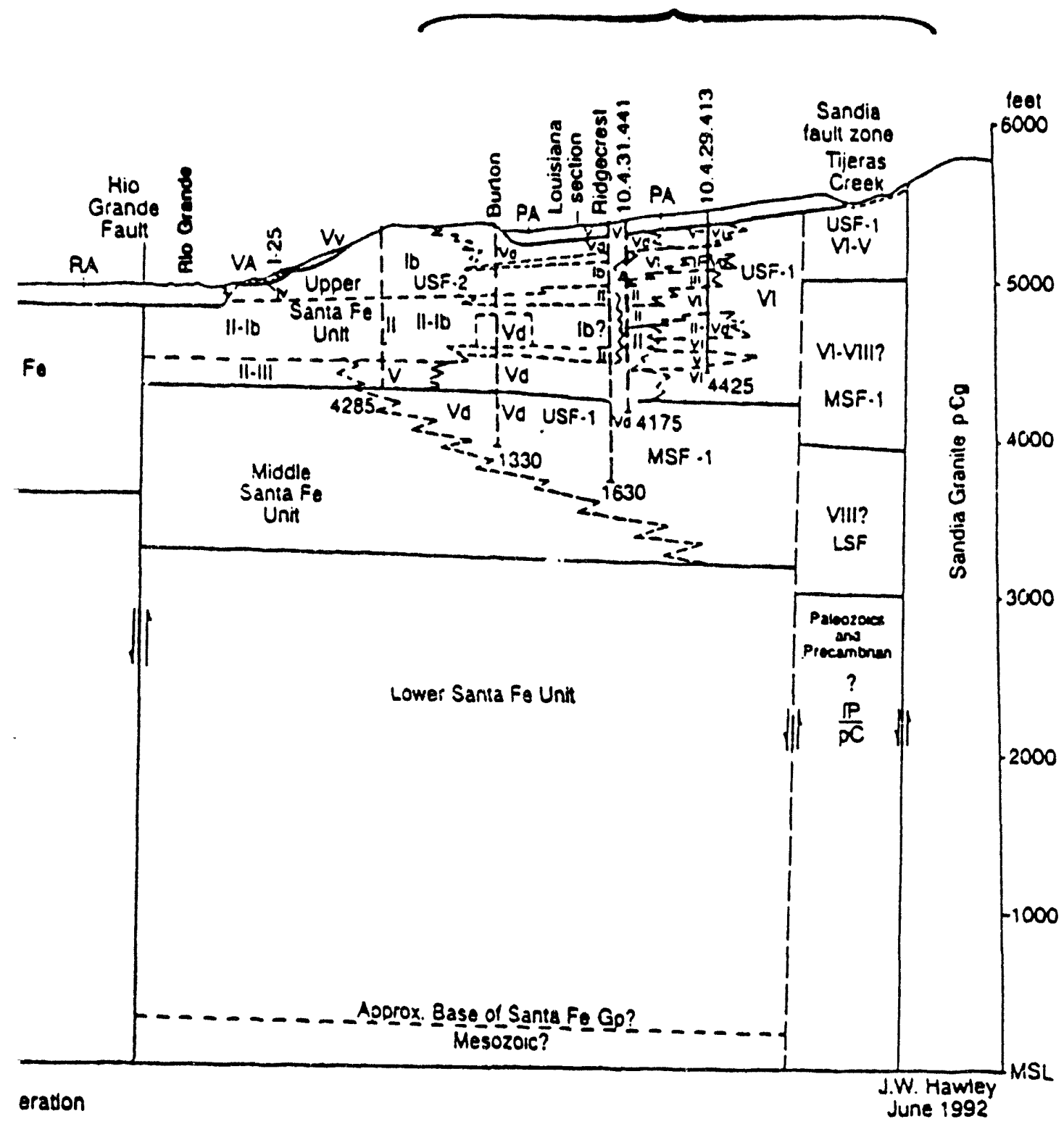

ction for the Northern SNL/KAFB Area (From igure 3-14 for location of cross section) 


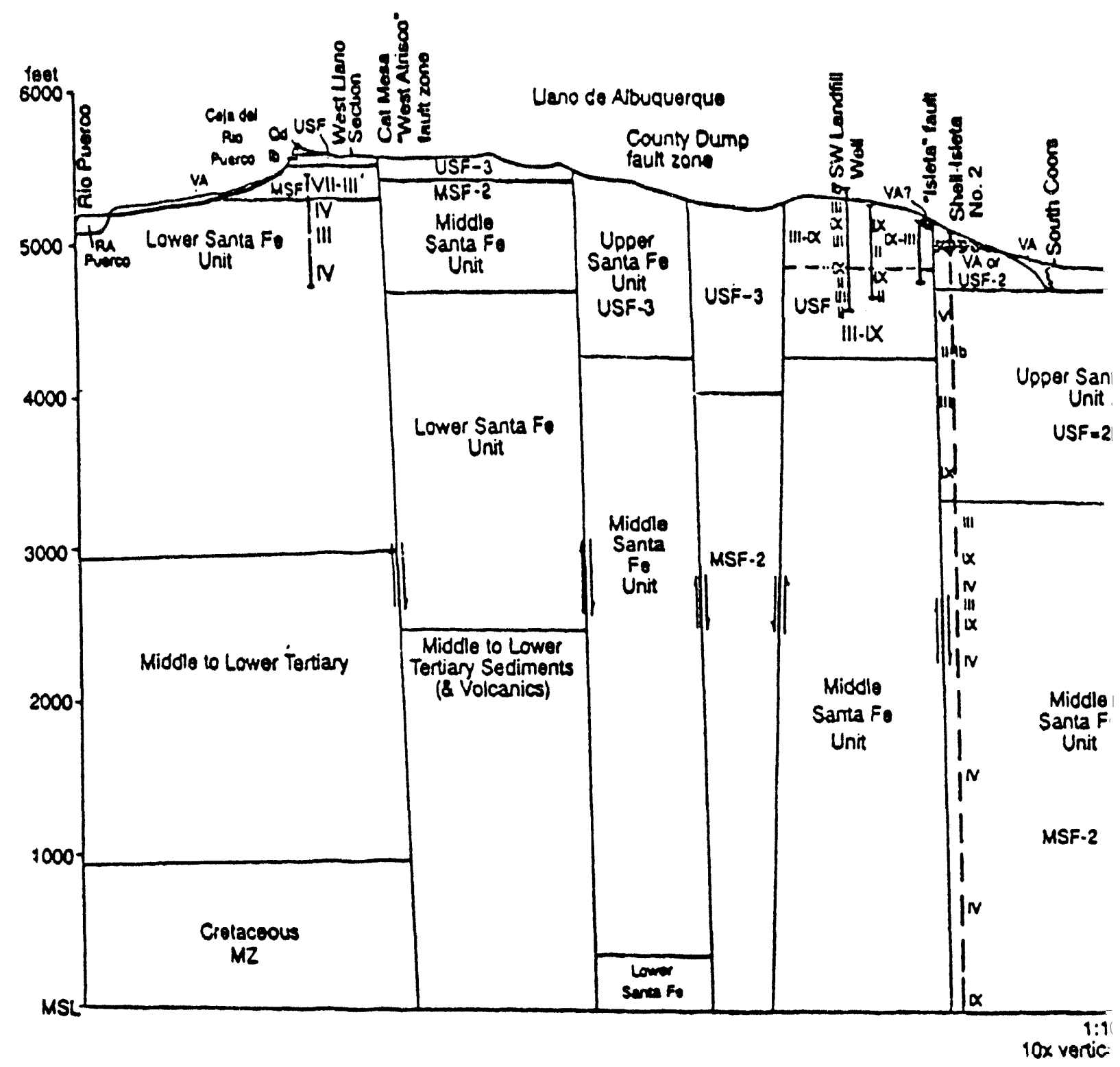

Figure 3-16. Pajarito Hydrogeologic Cros Hawley and Haase 1992; se 
301337.1160186

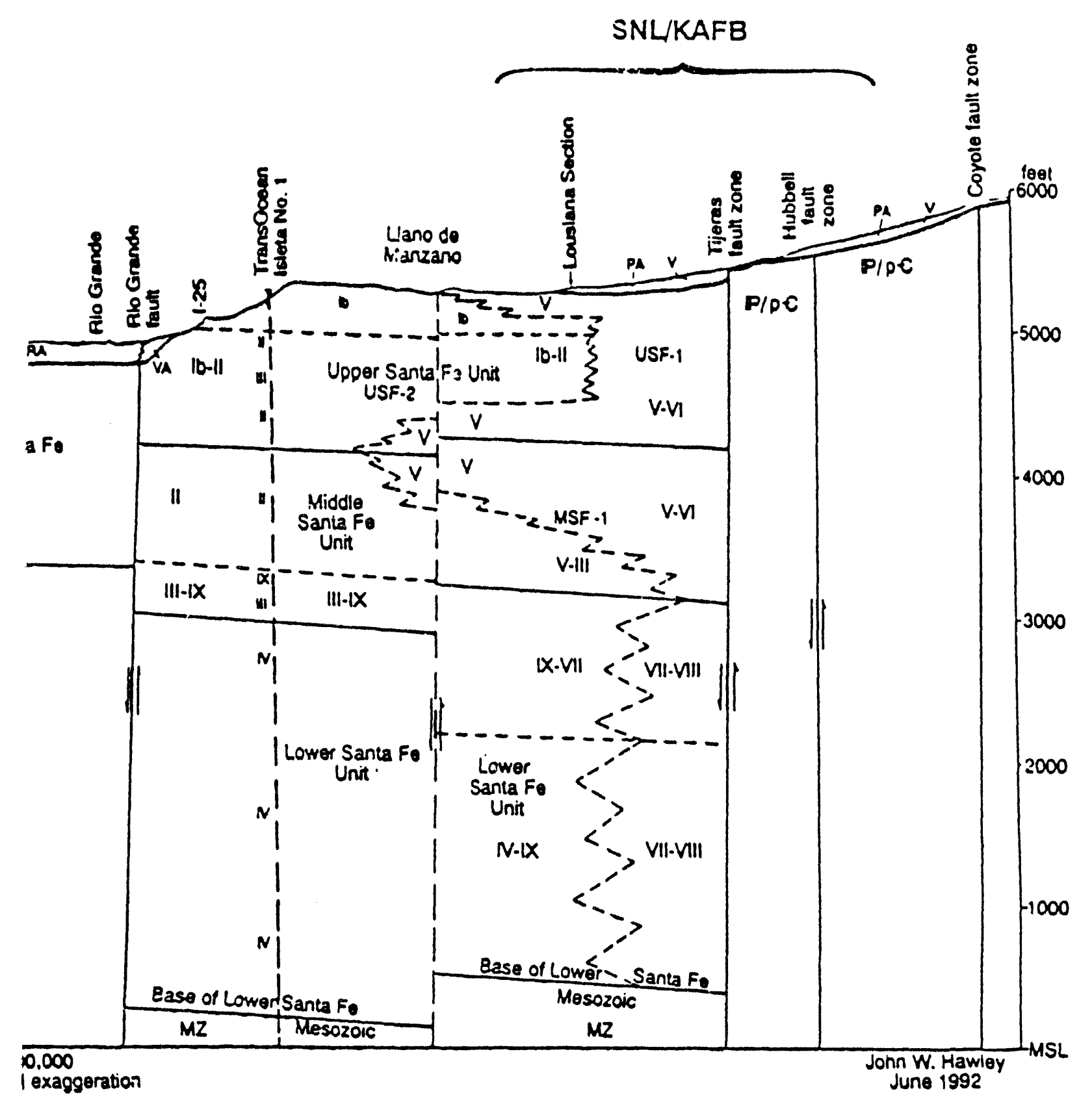

i Section for the Southern SNL/KAFB Area (From

? Figure 3-14 for location of cross section) 


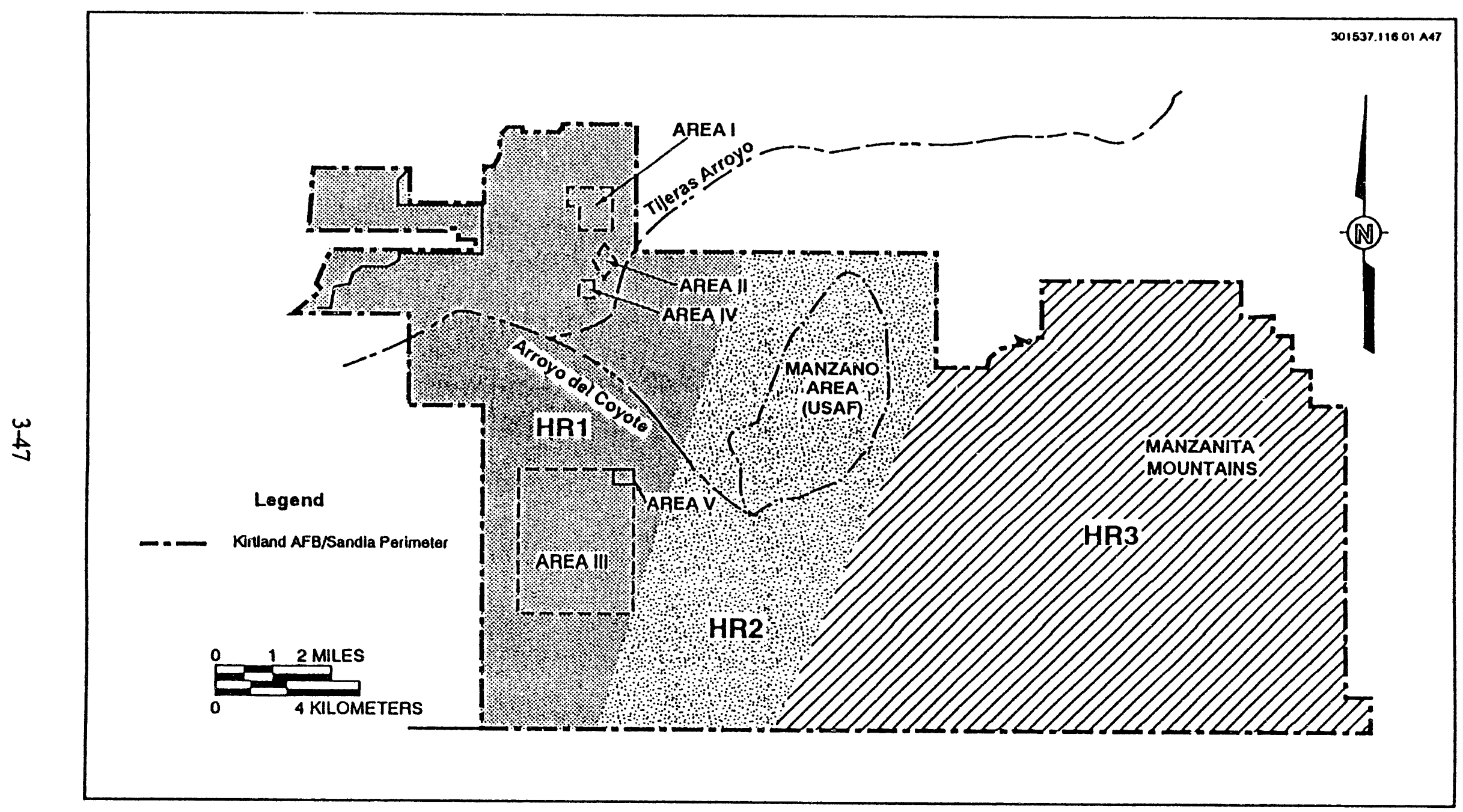

Figure 3-17. Hydrogeologic Regions in the SNL/KAFB Area 


\subsubsection{Geologic Controls on Hydrologic Parameters}

Geologic controls on saturated hydraulic conductivity, unsaturated hydraulic conductivity, and the spatial distribution of those parameters have not been evaluated at the SNL/KAFB site. However, Hawley and Haase (1992) estimated bedding connectivities and hydraulic conductivities for the various Santa Fe Group lithofacies based on estimates of sand + gravel versus silt + clay ratios, bedding thickness, bedding configuration, and bedding continuity (Table 3-5). Individual sand + gravel/silt + clay ratios are categorized in Table 3-5 as high $(>2)$, moderate $(0.5$ to 2$)$, and low $(<0.5)$.

Hawley and Haase (1992) suggest that grain-size differences exert a major influence on the hydraulic conductivity of a particular lithofacies. They took high sand + gravel/silt + clay ratios to indicate high hydraulic conductivities. For the lithofacies of the Santa Fe Group, hydraulic conductivity estimates range from high [ $>30 \mathrm{ft} /$ day $(9.2 \mathrm{~m} /$ day $)]$, moderate $[.03$ to $30 \mathrm{ft} /$ day $(.009$ to $9.2 \mathrm{~m} /$ day $)]$, and low [ $<0.3 \mathrm{ft} /$ day $(<.09 \mathrm{~m} /$ day $)]$. Bedding connectivity is an estimate of the degree to which groundwater can flow between individual beds.

Hawley and Haase (1992) suggest that high sand + gravel/silt + clay ratios, thick beds, and high bedding continuity favor high bedding connectivity, with bedding continuity being the most important parameter.

Results of the Santa Fe Group hydrogeologic studies (Hawley and Haase 1992) provide a starting point for estimation of hydrologic properties of HR1, which is underlain by Santa Fe Group strata. Unfortunately, there is no equivalent model available for estimation of such properties for the formations underlying HR2 and HR3. General estimates can be made of the hydrologic behavior of non-Santa Fe Group materials within the SNL/KAFB area (Table 3-6). Water-bearing characteristics can be used for rough estimation of hydrologic properties; that is, formations yielding large amounts of water likely have significantly higher hydraulic conductivities than formations with low water yields. Such estimates are imprecise at best, but likely provide order of magnitude information sufficient for a preliminary hydrologic analysis. Table 3-6 provides a general summary of lithologic and water-bearing characteristics of all stratigraphic units in the SNL/KAFB study area.

\subsection{Travertine Hills Geology}

Travertine Hills is located at the intersection of several major faults that transect SNL/KAFB (see Figures 3-4 and 3-18): the north-east-trending Tijeras Fault Zone, north-south-trending Hubbell Spring Fault to the south, and north-south-trending Sandia Fault to the north. As discussed in Section 3.2, additional faults, such as the Colorado Fault, might influence this area. Mapping of Travertine Hills was undertaken by Krumhansl and McConnell (in preparation) to provide geologic mapping coverage for this area at a resolution similar to or better than that available for the Mt. Washington Quadrangle (Myers and McKay 1970) in the eastern portion of SNL/KAFB. Travertine Hills might hold important keys to the paleoenvironmental and paleohydrologic settings of SNL/KAFB. What is the origin of the secondary carbonate at this locale? Is this carbonate related to past subaerial spring activity that might suggest a higher water table than exists at the present time? Or is the carbonate related to deposition by deep groundwater circulation in a hydrologic setting similar to the modern one? In addition, what is the importance of pedogenic processes in secondary carbonate accumulation at Travertine Hills? What importance do these processes have regarding paleoenvironmental reconstructions and modern surface and vadose zone 
Table 3-5

Summary of Parameters That Influence Groundwater Production of Santa Fe Group Lithofacies (From Hawley and Haase 1992)

\begin{tabular}{|c|c|c|c|c|c|c|c|}
\hline LITHOFACIES & $\frac{\text { SAND + GRAVEL }}{\text { SILT + CLAY }}$ & $\begin{array}{c}\text { BEDDING } \\
\text { THICKNESS } \\
\text { (ft) } \\
\end{array}$ & $\begin{array}{c}\text { BEDDING } \\
\text { CONFIGURATION } \\
\end{array}$ & $\begin{array}{c}\text { BEDDING } \\
\text { CONTINUITY } \\
\text { (ft) } \\
\end{array}$ & $\begin{array}{c}\text { BEDDING } \\
\text { CONNECTIVITY } \\
\end{array}$ & $\begin{array}{c}\text { HYDRAULIC } \\
\text { CONDUCTIVITY } \\
\end{array}$ & $\begin{array}{c}\text { GROUNDWATER } \\
\text { PRODUCTION } \\
\text { POTENTIAL } \\
\end{array}$ \\
\hline IV & High to moderate & $>5$ & Elongate & $>500$ & High & High to moderate & High \\
\hline Ib & High & $>5$ & Elongate & $>500$ & High & High & High \\
\hline $\mathbf{I}$ & High to moderate & $>5$ & Elongate & $>500$ & High & High to moderate & High to moderate \\
\hline II & High to moderate & $>5$ & Elongate & $>500$ & Moderate to high & High to moderate & High to moderate \\
\hline III & Low & 1 to 5 & Planar & $>500$ & Low & Low & Low \\
\hline IV & Low to moderate & 1 to 5 & Planar to elongate & 100 to 500 & Low to moderate & Moderate to low & Moderate to low \\
\hline $\mathbf{v f}$ & Moderate & 105 & Elongate to lobate & 100 to 500 & Moderate & Moderate to low & Moderate to low \\
\hline Vd & Moderate to high & $>5$ & Elongate to lobate & 100 to 500 & High & Moderate to high & Moderate to high \\
\hline $\mathbf{v}$ & Moderate & 1 to 5 & Elongate to lobate & 100 to 500 & Moderate to high & Moderate & Moderate \\
\hline VI & High & $>5$ & Lobate & $<100$ & Moderate & Moderate to high & Moderate \\
\hline VII & Moderate & 1 to 5 & Elongate to lobate & 100 to 500 & Moderate to high & Moderate to low & Moderate to low \\
\hline VIII & High & $>5$ & Lobate & $<100$ & Moderate & Moderate to low & Moderate to low \\
\hline $\mathbf{L X}$ & Low & $<1$ & Planar & $>500$ & Low & Low & Low \\
\hline $\mathbf{x}$ & Low & $<1$ & Planar & $>500$ & Low & Low & Low \\
\hline
\end{tabular}


Table 3-6

Lithologic and Water-Bearing Characteristics of Stratigraphic Units in the SNL/KAFB Study Area

\begin{tabular}{|c|c|c|c|c|c|c|}
\hline ERA & SYSTEM & SERIES & UNrI & $\begin{array}{c}\text { TIICKNESS } \\
\text { (ii) }\end{array}$ & I.ITIIOLOGY & $\begin{array}{l}\text { WATER-BEARINO } \\
\text { CIIARACTERISTICS }\end{array}$ \\
\hline \multirow{4}{*}{$\begin{array}{l}\mathbf{C} \\
\mathbf{B} \\
\mathbf{N} \\
\mathbf{O} \\
\mathbf{2} \\
0 \\
1 \\
\mathbf{C}\end{array}$} & \multirow[t]{3}{*}{ Quaternary } & \multirow[t]{2}{*}{ Receilt } & Alluvieum & $010120 \%$ & $\begin{array}{l}\text { Cobbles, gravel, sund, silt, and } \\
\text { clay: unconsolideted. Gieucrally } \\
\text { umdellies valley fluoror. }\end{array}$ & 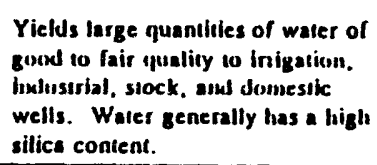 \\
\hline & & & Dajada Deposits & 010200 & 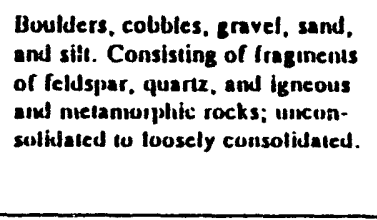 & 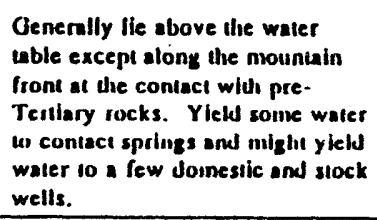 \\
\hline & & Pleislocena (?) & & & $\begin{array}{l}\text { Boulders, cubbies. zravel, satul. } \\
\text { silt, and chay; unconsolidated to } \\
\text { consultdated but generally weakly }\end{array}$ & $\begin{array}{l}\text { Ylelds large quantities of water of } \\
\text { good quality to municipal. } \\
\text { industrial, irrigation, stock. and }\end{array}$ \\
\hline & Teniary & Mlocene (?) & Santa Fo Oroup & 0106.100 & $\begin{array}{l}\text { cememied. Includes incerbedded } \\
\text { volcanic matesial lucally. }\end{array}$ & $\begin{array}{l}\text { slomestic wells. Water generally } \\
\text { lass a hiyli silica coureur. }\end{array}$ \\
\hline \multirow{2}{*}{$\begin{array}{l}\text { C } \\
\text { E } \\
\mathbf{N} \\
\mathbf{O} \\
\mathbf{Z} \\
\mathbf{O} \\
\mathbf{J} \\
\mathrm{C}\end{array}$} & \multirow[t]{2}{*}{ Terilary (coni'd) } & Eocene & $\begin{array}{c}\text { Espinosa Volcanic Rocks of } \\
\text { Sicams (1943) }\end{array}$ & 400101.400 & Breccia, conglonerate, and turf. & $\begin{array}{l}\text { Deeply buried if present: no wells } \\
\text { are known to be completed in this } \\
\text { formation. }\end{array}$ \\
\hline & & $\begin{array}{l}\text { Eocene anud Oligocer.e } \\
\text { (?) }\end{array}$ & Oalisteo l'omiation & 900104.000 & Sandstone, sand, clay, and shale. & Do. \\
\hline \multirow{2}{*}{$\begin{array}{c}\mathbf{M} \\
\mathbf{E} \\
\mathbf{S} \\
\mathbf{0} \\
\mathbf{Z} \\
\mathbf{0} \\
\mathbf{1} \\
\mathbf{C}\end{array}$} & \multirow[t]{2}{*}{ Crciaceous } & \multirow[t]{2}{*}{ Upper } & Mesn Verde Group & $1.500102,000$ & $\begin{array}{l}\text { Predominandly gny to black } \\
\text { slaale; includes several prominent } \\
\text { beds of buff-colured to gray } \\
\text { samistone and soine thin lieds of } \\
\text { coal. }\end{array}$ & $\begin{array}{l}\text { No wells sap this unit because of } \\
\text { great depth. Saixd stone beds yield } \\
\text { water of fair to poor quality to } \\
\text { stock and domestic wells in } \\
\text { adjuining areas. }\end{array}$ \\
\hline & & & Mancos Shale & 900102,500 & $\begin{array}{l}\text { Predoninautly gny to black } \\
\text { shale; includes several bedis of } \\
\text { bulf-colored to gray sandstonc. }\end{array}$ & vo. \\
\hline
\end{tabular}

a: Bjoikland and Maxwell (194i) 
Table 3-6

Lithologic and Water-Bearing Characteristics of Stratigraphic Units in the SNL/KAFB Study Area

(Continued)

\begin{tabular}{|c|c|c|c|c|c|c|}
\hline ERA & SYSTEM & SERIES & UNIT & $\begin{array}{c}\text { TIIICKNESS } \\
\text { (ii) }\end{array}$ & I.TrHOLOGY & $\begin{array}{l}\text { WATER-BEARING } \\
\text { CIIARACTERISTICS } \\
\end{array}$ \\
\hline \multirow{7}{*}{$\begin{array}{l}\text { M } \\
\mathrm{E} \\
\mathbf{S} \\
0 \\
2 \\
0 \\
1 \\
\mathrm{C}\end{array}$} & & Lower & Dakota Samustone & 7510110 & $\begin{array}{l}\text { Sandstone. buffi to inn: } \\
\text { inteibedded shale. }\end{array}$ & Do. \\
\hline & \multirow[t]{5}{*}{ Jurnssic } & \multirow[t]{5}{*}{ Upper } & Murrison Formation & 21010660 & $\begin{array}{l}\text { Sliale, green, pink, gray, and } \\
\text { maroon, and white atud buff } \\
\text { saindstone imenibers. }\end{array}$ & Do. \\
\hline & & & Buff Samdsione & 10010140 & Sandstone, buff. & Do. \\
\hline & & & $\begin{array}{l}\text { Sumunerville } \\
\text { Fornuation }\end{array}$ & 60 to 120 & $\begin{array}{l}\text { Sandstune and sandy sisale. red to } \\
\text { eray. }\end{array}$ & DO. \\
\hline & & & Toctitto l.iniestone & 4010250 & $\begin{array}{l}\text { Two beds of limeslone separated } \\
\text { by a lifick bed of gyprsum. }\end{array}$ & $\begin{array}{l}\text { Buried deeply; yields little or no } \\
\text { water. Water has a higli sulfate } \\
\text { comtent. }\end{array}$ \\
\hline & & & Entrada Sandstone & 16010220 & $\begin{array}{l}\text { Sandstone, cross-bedded, red to } \\
\text { gray. }\end{array}$ & $\begin{array}{l}\text { Buried deeply: yields water to } \\
\text { stock and domestic wells in } \\
\text { adjoining areas. Quality of water } \\
\text { gencrally poor because of hight } \\
\text { sulfate concentratioun. }\end{array}$ \\
\hline & Triassic & Upper & Chinle l'ormation & 1.100 & $\begin{array}{l}\text { Shale. red, and channel deposits } \\
\text { of shaly sandstone; connains beds } \\
\text { of red sambsusc al lep and } \\
\text { ixoltunn. }\end{array}$ & $\begin{array}{l}\text { Buried deeply: ylelds no water to } \\
\text { wells. Sandy zones yield water to } \\
\text { domestic and stock wells in } \\
\text { adjoining areas. Quality of water } \\
\text { is getierally pour. }\end{array}$ \\
\hline
\end{tabular}


Table 3-6

Lithologic and Water-Bearing Characteristics of Stratigraphic Units in the SNL/KAI'B Study Area

(Concluded)

\begin{tabular}{|c|c|c|c|c|c|c|}
\hline ERA & SYSTEM & SERIES & UNrT & $\begin{array}{l}\text { TIIICKNESS } \\
\text { (fi) }\end{array}$ & LITIIOLOOY & $\begin{array}{l}\text { WATER-BEARING } \\
\text { CIIARACTERISTICS }\end{array}$ \\
\hline \multirow{6}{*}{$\begin{array}{l}\mathbf{P} \\
\hat{A} \\
\mathbf{L} \\
\mathbf{E} \\
\mathbf{0} \\
\mathbf{Z} \\
\mathbf{0} \\
\mathbf{1} \\
\mathbf{C}\end{array}$} & \multirow[t]{4}{*}{ Peruilan } & \multirow[t]{4}{*}{ 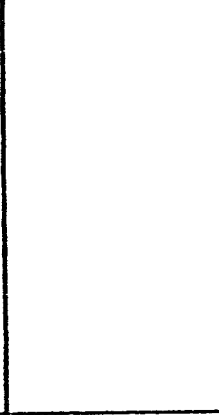 } & San Aindres L.lunestune & 47 10 470 & $\begin{array}{l}\text { Imterbedded limestone. eypsum. } \\
\text { and sainlstone. }\end{array}$ & $\begin{array}{l}\text { Buried deeply: ylelds water to } \\
\text { slock and doniestic wells in } \\
\text { adjoining areas. }\end{array}$ \\
\hline & & & Glorieza Sandstune & 2010220 & $\begin{array}{l}\text { Sandstone, fine-grained, buff to } \\
\text { white, contains gypsum in sone } \\
\text { areas. }\end{array}$ & Do. \\
\hline & & & Yeso Purnuation & $4(x) 101.100$ & $\begin{array}{l}\text { Sandstone and siltstone, tan- } \\
\text { brown to red. }\end{array}$ & $\begin{array}{l}\text { Buried deeply; yields little or no } \\
\text { water to wells. }\end{array}$ \\
\hline & & & Abo Pormation & 81010950 & $\begin{array}{l}\text { Samdstone, fine- to coarse- } \\
\text { grained, and silt stone; red to } \\
\text { grny. }\end{array}$ & $\begin{array}{l}\text { Buried deeply: yields small } \\
\text { quantities of water to slock wells } \\
\text { in adjoining areas. }\end{array}$ \\
\hline & \multirow[t]{2}{*}{ Penusylvanian } & & Madera t.tunestune & 4501102.0000 & $\begin{array}{l}\text { Limestone. gray to real; upper } \\
\text { part includes more clastic inaterial } \\
\text { ulan luwer part. }\end{array}$ & $\begin{array}{l}\text { Buried deeply: arkosic nember } \\
\text { yields stmall quantities of water to } \\
\text { slock and domestic wells in } \\
\text { adjoining areas. }\end{array}$ \\
\hline & & & Sandia Forruation & $010+15$ & 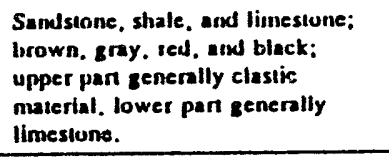 & $\begin{array}{l}\text { Duried deeply: yietds stmall } \\
\text { quantities of water } 10 \text { slock and } \\
\text { domestic wells in adjoining areas. }\end{array}$ \\
\hline \multicolumn{2}{|r|}{ Procanibsian } & & & 18.0000 & Metamorplite and igneous rocks. & $\begin{array}{l}\text { Surficial weachered and finctured } \\
\text { zones yicld sumall quantilites of } \\
\text { water to spings and wells along } \\
\text { nountain front for stock and } \\
\text { domestic supplies. }\end{array}$ \\
\hline
\end{tabular}




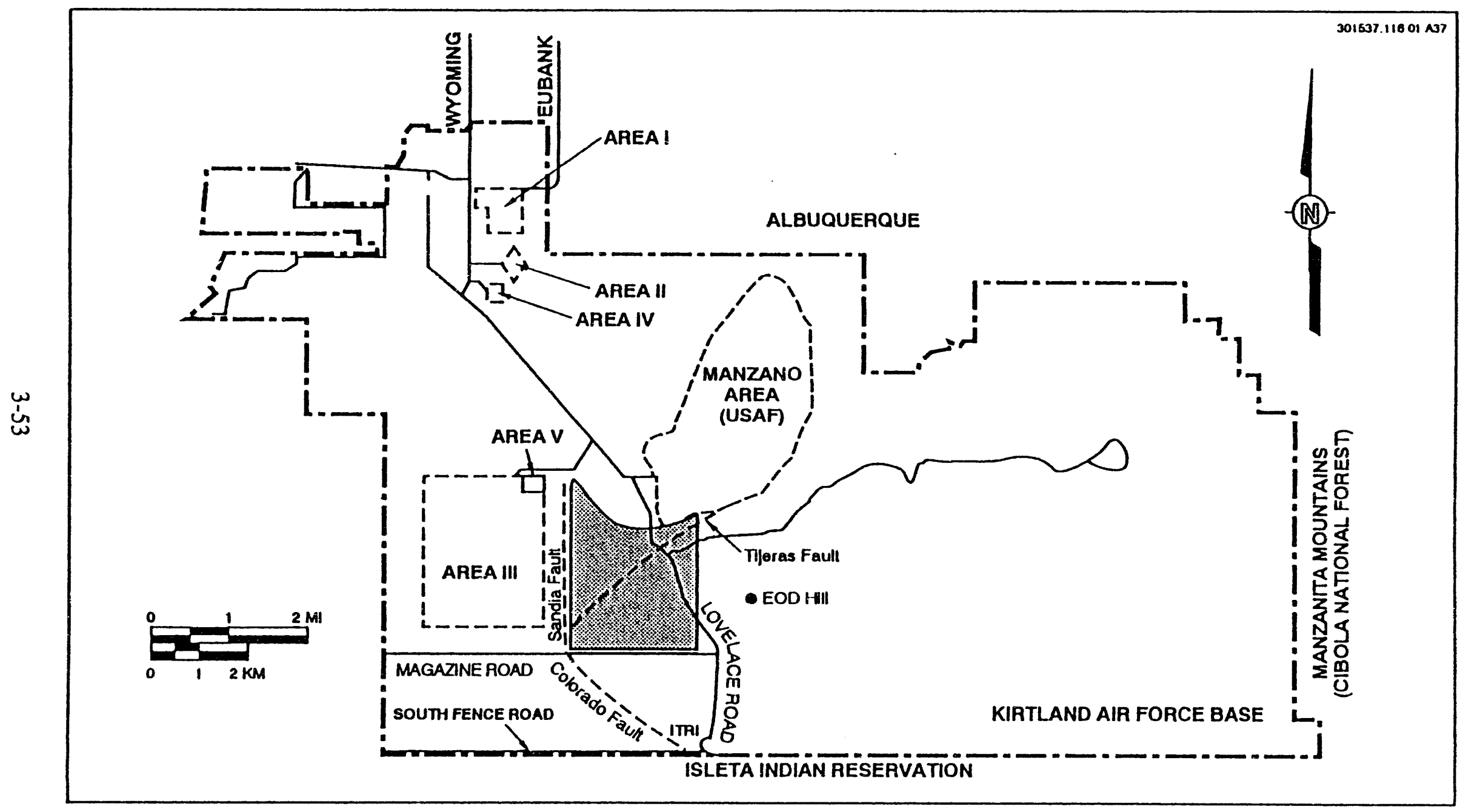

Figure 3-18. Index Map to the Travertine Hills Area Geologic Map (From Krumhansl and McConnell, in prep.) 
hydrologic processes at SNL/KAFB? What impact could paleohydrologic reconstruction of the Travertine Hills have on ER sites such as the mixed waste and chemical waste disposal sites in TA-III and TA-V?

Recent mapping activities by Krumhansl and McConnell (in preparation) cover an area of $2 \mathrm{mi}^{2}\left(6 \mathrm{~km}^{2}\right)$ within Travertine Hills (Figures 3-4 and 3-18). The southern border of the mapping area runs due east and is located immediately north of Magazine Road, whereas the western boundary is a north-south line that lies immediately west of Travertine Hills. The eastern boundary forms a north-south line east of Lovelace Road and about $300 \mathrm{ft}(100 \mathrm{~m})$ west of EOD Hill (Figure 3-18). The northern boundary is the present-day stream channel of Arroyo del Coyote.

Krumhansl and McConnell (in preparation) divide their field area into four fault-bounded structural blocks. The first structural block lies west of the Sandia Fault. Its exact location is obscured in the north by a large alluvial fan complex associated with the Arroyo del Coyote drainage basin, and in the south by a second, smaller, unnamed alluvial fan complex.

Farther east, between the Sandia and Tijeras Faults, lies a wedge-shaped region of low hills composed of Precambrian units. This second structural block is a continuation of the Precambrian and Paleozoic units found in Four Hills and the Sandia Mountains farther northeast. Lithologies within the second block include granite, diorite, gneiss, and metaquartize similar to those found within Four Hills and the Sandia Mountains.

The third structural block lies southeast of the Tijeras Fault and contains a small graben or syncline filled with at least $1,100 \mathrm{ft}(300 \mathrm{~m})$ of Cenozoic sediments. The greatest accumulation of sediments in the third block is immediately east of Travertine Hills.

Although this basin fill probably correlates with the coarse, upper member of the Santa Fe Group (i.e., late Tertiary to Quaternary in age), it is possible that the sediments accumulated during the early Tertiary (i.e., Laramide age), synchronous with an episode of movement along the Tijeras Fault Zone. Limestone-boulder conglomerate forms the lower portion of the stratigraphic sequence of the third block. This unit is overlain by a granite-pebble conglomerate probably derived from the second structural block. The Travertine Hills are small hogbacks that reflect post-depositional tectonic tilt of these sediments.

The fourth and final structural block lies east of Lovelace Road. Outcrops of the fourth block are found in a number of low hills that contain interbedded limestone and sandstoneconglomerate-siltstone layers of the Madera Group. A portion of the limestone boulders of the third structural block might have been derived from the fourth block. The boundary between the basin-fill sediments of the third block and the Paleozoic rocks of the fourth block is obscured. Units within the Madera Group in the fourth block generally dip 10 to 20 degrees to the west or southwest, except in the north along Arroyo del Coyote, where they dip to the north to northwest with declinations of up to 60 degrees. This change is probably related to the close proximity of the Tijeras Fault Zone.

The region has also been broken by numerous smaller faults. The dominant fault set of these smaller faults has a general north-south orientation, although the outcrops have also been 
offset along at least two east-west-trending minor faults. Local hydrothermal mineralization (pyrite, barite, trace sphalerite, and trace galena) occurs on these faults. Many questions remain about the structural, stratigraphic, paleoenvironmental, and paleohydrologic settings of Travertine Hills. Additional geologic work might help address the questions of this key locale.

\subsection{Geophysics}

Geophysical methods offer great potential for defining subsurface geologic structure needed for the SWHC project. The initial step in planning for future geophysical activities has been to research past geophysical activities on or nea. SNL/KAFB, determining what has worked in the past, and evaluating past activities in relation to current needs. Figure 3-19 shows the approximate locations of the geophysical investigations described in Sections 3.6.1 through 3.6.3.

The use of geophysics on and near SNL/KAFB can be traced to the early 1950s. Driven by petroleum exploration, early work consisted primarily of magnetic and gravity investigations. Petroleum exploration waned after 1956. Activities in the Albuquerque area lay fallow until the early 1970s, when renewed oil exploration and studies of the Rio Grande Rift spawned a fluriy of geophysical work. Again the petroleum potential of the Albuquerque Basin proved uneconomical, but an active study of the Rio Grande Rift remains to the present, with participation by government agencies and local universities.

Studies of the subsurface structure directly on SNL/KAFB proper were limited prior to the energy crisis of the late 1970 s, when a study was initiated to evaluate the geothermal potential of KAFB. This and later efforts provide seismic, gravity, and magnetotelluric data for evaluation.

Environmental geophysical surveys on SNL/KAFB began in 1984 and continue to the present. These surveys, designed for shallow investigation, are vital to SNL/NM ER efforts but provide little site-wide structural information. Similarly, geotechnical uses of geophysical techniques have provided important shallow information but have seldom exceeded a few feet in depth.

\subsubsection{Geophysical Investigations for Defining Geologic Structure}

Four geophysical methods have been employed to provide subsurface structural information on and near SNL/KAFB. These include gravity, seismic, magnetic, and electromagnetic investigations.

\subsubsection{Gravity Investigations}

The framework for gravity studies was begun in 1937, when the first absolute gravity station was established in Albuquerque. To date there are ten absolute gravity stations in the 


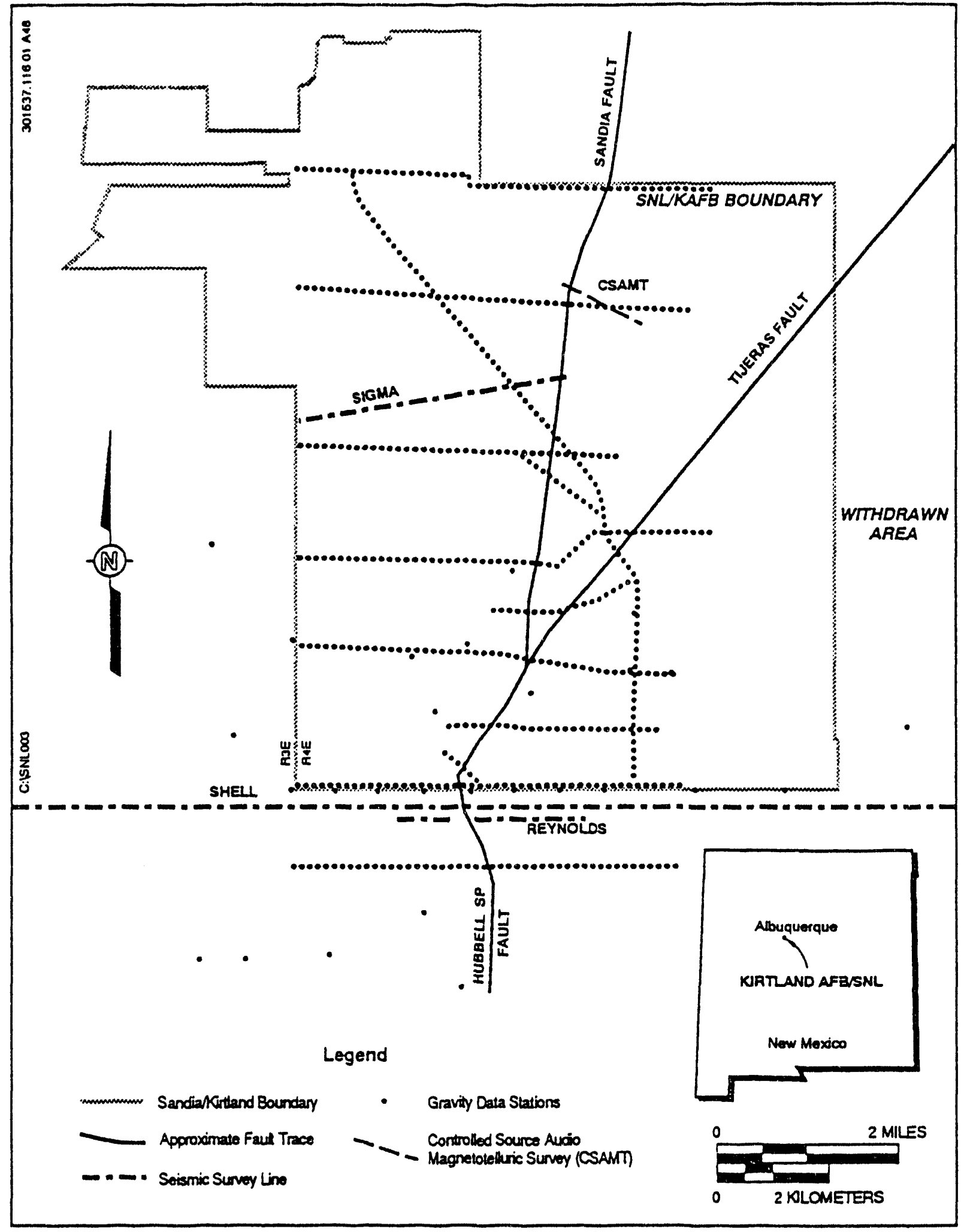

Figure 3-19. Locations of Gravity, Seismic, and CSAMT Data and Major Faults at KAFB 
vicinity of SNL/KAFB, maintained by the National Geodetic Survey and the Defense Mapping Agency.

The earliest gravity surveys in the Albuquerque Basin were initiated for petroleum exploration. The Humble Oil Company located at least one oil exploration well in 1953 based on a gravity and magnetic anomaly (Black 1982). When this phase of exploration for oil ended, no further detailed gravity work was reported until the early 1970s.

The development of a codified gravity description for the Albuquerque area was initiated primarily in response to the recognition of the Rio Grande Rift as a significant tectonic feature. The USGS, aided by local universities, produced a series of gravity studies and maps, starting with Cordell et al. (1973) and ending with Cordell et al. (1982). The development of the USGS gravity database was continued by Heywood (1992). The definitive effort to model the Albuquerque Basin based on this gravity data was completed by Birch (1982).

Two gravity studies have been conducted to investigate the fault structures on SNL/KAFB proper. Data was gathered along six roughly east-to-west profiles in support of a geothermal study in 1981 (Parker, in Grant 1981). Several more gravity measurements have recently been taken across the major fault zones, and analysis is in progress (Goodrich 1992, in draft). The locations of the USGS, Parker, and Goodrich gravity data on SNL/KAFB proper are shown in Figure 3-19.

Neither of the two studies on SNL/KAFB proper have been fully successful in defining the fault structure. The major difficulty is separating the effect of the relatively small features of interest from the large gravitational effects of the entire basin.

\subsubsection{Seismic Investigations}

Both seismic reflection and seismic refraction surveys have been conducted on and near $\mathrm{SNL} / \mathrm{KAFB}$. The seismic reflection surveys were designed for defining subsurface structure. All but one of the seismic refraction surveys, discussed in Section 3.6.3, were designed for shallow, geotechnical purposes.

Shell Oil Company collected seismic reflection data along numerous profiles in the Albuquerque Basin. One profile (Shell 65) was along the KAFB south fence, and has been interpreted for deep structural details (Russell and Snelson 1990). A 3-mi $(4.8-\mathrm{km})$ line of seismic reflection data was obtained across Lovelace Road, just south of Tijeras Arroyo. This line of data was taken in 1984 by Sigma Geoservices in support of KAFB construction activities. The data were interpreted to show three fault zones, approximately $2,300 \mathrm{ft}$ $(700 \mathrm{~m})$ of vertical displacement, and east-dipping fault blocks (Dobecki, in Sigma Geoservices 1984). A short line [560 ft $(170 \mathrm{~m})]$ of seismic reflection data was taken by Charles B. Reynolds \& Associates in 1976. This effort was undertaken as a demonstration of feasibility and shows little subsurface structure. The locations of the seismic reflection profiles on and near SNL/KAFB are shown in Figure 3-19. 
A single seismic refraction study has been conducted for the purpose of investigating subsurface structure. A high-explosive hlast on McCormick Ranch was used as a seismic source, and depth to basement and depth of valley fill were estimated to a first approximation (Grant 1981).

These past seismic studies on and near SNL/KAFB demonstrate the ample potential in seismic methods for defining subsurface structure. A major difficulty facing future seismic surveys is the large offset of the faults. A survey designed for good resolution over shallow basement will not traverse $(1,000-\mathrm{ft})$ offset and retain any true reflective or refractive character.

\subsubsection{Magnetic Investigations}

A single aeromagnetic study of the Albuquerque area has been identified (Cordell 1976). As with the regional gravity studies, the magnetic character of the relatively small features on $\mathrm{SNL} / \mathrm{KAFB}$ proper were masked by the nearby mountains to the east and the deep basin to the west.

Although little ground-based magnetometry has been employed on SNL/KAFB for other than burial site investigations, the utility of ground-based magnetometry for subsurface investigations was demonstrated on the western side of the Albuquerque Basin (Jiracek et al. 1982).

\subsubsection{Electromagnetic Investigations}

The controlled-source audio frequency magnetotelluric (CSAMT) method was used to investigate subsurface structure on SNL/KAFB. It was successful in identifying over $1,600 \mathrm{ft}(500 \mathrm{~m})$ of offset on the Sandia Fault just northeast of the KAFB golf course (Bartel et al. 1981). Additional studies with CSAMT and other electromagnetic methods were performed in nearby parts of the Albuquerque Basin (Jiracek et al. 1982). The location of the CSAMT survey on SNL/KAFB is shown on Figure 3-19.

\subsubsection{Environmental Geophysics}

The use of geophysical methods for detecting shallow targets of environmental interest is a recent development on SNL/KAFB. Typically, the location of buried objects or the trenches containing buried material are sought.

The CWL in TA-III was surveyed in 1984 using magnetometry, electromagnetic ground conductivity, and ground-penetrating radar (GPR) (Weston 1984). The CWL was resurveyed, and the Classified Waste Landfill and Radioactive Waste Landfill in TA-II were surveyed in 1991 by two prototype explosive ordnance detectors developed by the Navy. These systems, designed to provide rapid coverage of large artillery and bombing ranges, employ grouped arrays of magnetometers and GPR antennae towed behind a vehicle (Naval Research Laboratory 1992). 
A magnetometer and a ground conductivity survey were conducted by the Albuquerque office of the USGS to locate burials in the vicinity of the KAFB riding stables (Heywood 1993). Additional magnetometer and ground conductivity surveys were used to map burial trenches in the TA-III MWL prior to a drilling effort (Hyndman 1992). A small CSAMT survey was recently conducted in TA-V to map the plume from a reactor cooling-water surge, and results are in preparation (Peace 1993).

The environmental surveys had mixed results. Those surveys that collected dense data using the proper instruments were successful in locating buried objects and burial trenches.

\subsubsection{Geotechnical Investigations}

Shallow seismic refraction surveys have been used to gain geotechnical information for designing structure foundations and high-explosive test sites. These surveys investigated to only a few feet below the surface and provided no information on underlying structure. Refraction methods were also used to investigate several landfills, again yielding no structural information. The deepest refraction surveys probed to depths of $300 \mathrm{ft}(91.4 \mathrm{~m})$ on and adjacent to McCormick Ranch (Bedsun 1983).

\subsection{Summary}

The first step in preparing a site-wide hydrogeologic CM is to compile and evaluate the relevant existing data for SNL/KAFB. A wide variety of background materials already exist that will aid in developing an SNL/KAFB site-specific geology framework. A synopsis of available literature is presented in this annual report for the stratigraphy, structural geology, hydrogeologic units, and geophysics of the east-central Albuquerque Basin. In addition, preliminary results of ongoing mapping in the Travertine Hills are outlined.

During 1993 and beyond, surficial and subsurface geologic work will attempt to facilitate surface, vadose, and saturated zone hydrologic investigations over the roughly $82-\mathrm{mi}^{2}$ $\left(211-\mathrm{km}^{2}\right) \mathrm{SNL} / \mathrm{KAFB}$ reservation. The geologic mapping will help direct surface and subsurface hydrologic investigations in an optimal, cost-effective manner. Two advantages are anticipated from this work: (1) the geoiogic mapping should greatly reduce the number of shallow borings, trenches, and other excavations required for surface and shallow subsurface hydrologic studies, and (2) by using a phased approach, planning for and execution of subsequent phases of this and related tasks can proceed in an efficient, costeffective manner.

Details of the site-wide geologic effort for 1993 and subsequent years are still in a planning

stage. Details of this effort will be included in appropriate programmatic documents. Tasks within the site-wide geology program include the following:

1. Define and map in three dimensions the major hydrogeologic (e.g., surficial, basin-fill, and bedrock) units for areas involved in SNL/NM's ER Program. These units will lie within the surface, vadose, and saturated zone hydrologic regimes. Mapping units will be compatible with USGS, New Mexico Bureau of Mines and Mineral Resources [e.g., see Hawley and Haase (1992)], or other stratigraphic approaches [e.g., Lambert (1968)] 
whenever possible. However, this work will require a more detailed division of geologic units than has been previously done on SNL/KAFB. New stratigraphic units might need to be defined. Stratigraphic units will be correlated with similar units in adjacent areas to the extent possible.

2. Establish the basic characteristics (e.g., mineralogy, petrology, sedimentology, and pedology) of the mapping units.

3. In combination with other activities in the SWHC program, develop a three-dimensional $\mathrm{CM}$ of the geologic framework of the east-central Albuquerque Basin that can be used in building more appropriate numerical models of the basin geohydrology, and prepare appropriate graphical materials (e.g., maps, cross sections, and fence diagrams) that illustrate the CM.

4. Satisfy documentation and quality assurance requirements.

5. Provide other geologic and programmatic requirements, as needed, in support of SNL/NM's ER Program.

\subsection{References}

Aiken, C.L.V., A. W. Laughlin, and F. West, 1978. Residual Bouguer Gravity Anomaly Map of New Mexico, LA-7466-MPA, Los Alamos Scientific Laboratory, Los Alamos, NM.

Ander, M. E., 1980. Geophysical Study of the Crust and Upper Mantle Beneath the Central Rio Grande Rift and Adjacent Great Plains and Colorado Plateau, unpublished Ph.D. dissertation, University of New Mexico, 218 pp.

Baars, D. L., 1982. Paleozoic History of the Albuquerque Trough: Implications of Basement Control on the Rio Grande Rift, New Mexico Geological Society Guidebook 33, pp. 153-157.

Bartel, L. C., C. W. Ray, R. D. Jacobson, and P. M. Drozda, 1981. Use of CSAMT Technique to Map a Fault on Kirtland Air Force Base, in Geothermal Studies at Kirtland Air Force Base, New Mexico, Appendix A, SAND81-0852, May 1981, Sandia National Laboratories, Albuquerque, NM.

Bedsun, D. A., 1983. Summary of Geotechnical Testing and Material Models for Subsurface Soil Conditions at McCormick Ranch, Kirtland Air Force Base, New Mexico, Letter Report NMERI 7.11-TA7-20.

Birch, F. J., 1982. Gravity Models of the Albuquerque Basin. Rio Grande Rift, New Mexico, Geophysics, vol. 47, pp. 1185-1197.

Black, B. A., 1982. Oil and Gas Exploration in the Albuquerque Basin, New Mexico Geological Society Guidebook 33, pp. 313-324. 

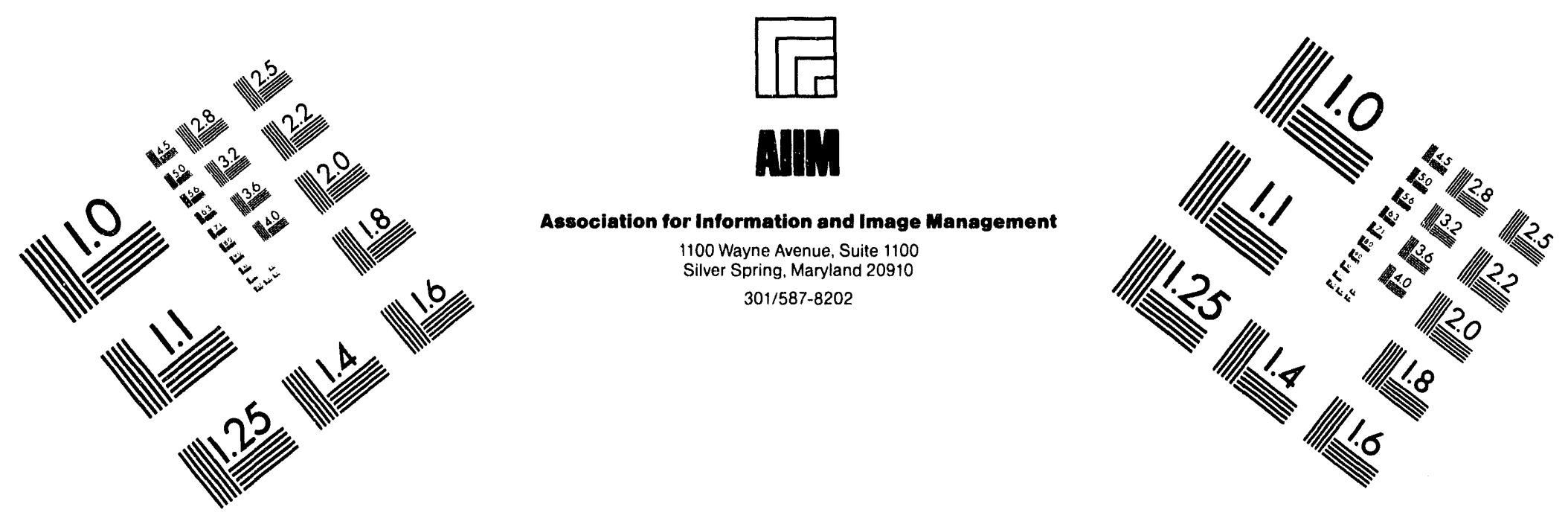

\section{Centimeter}

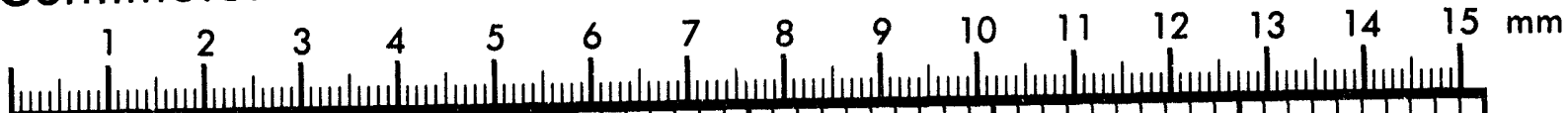
1 Inches
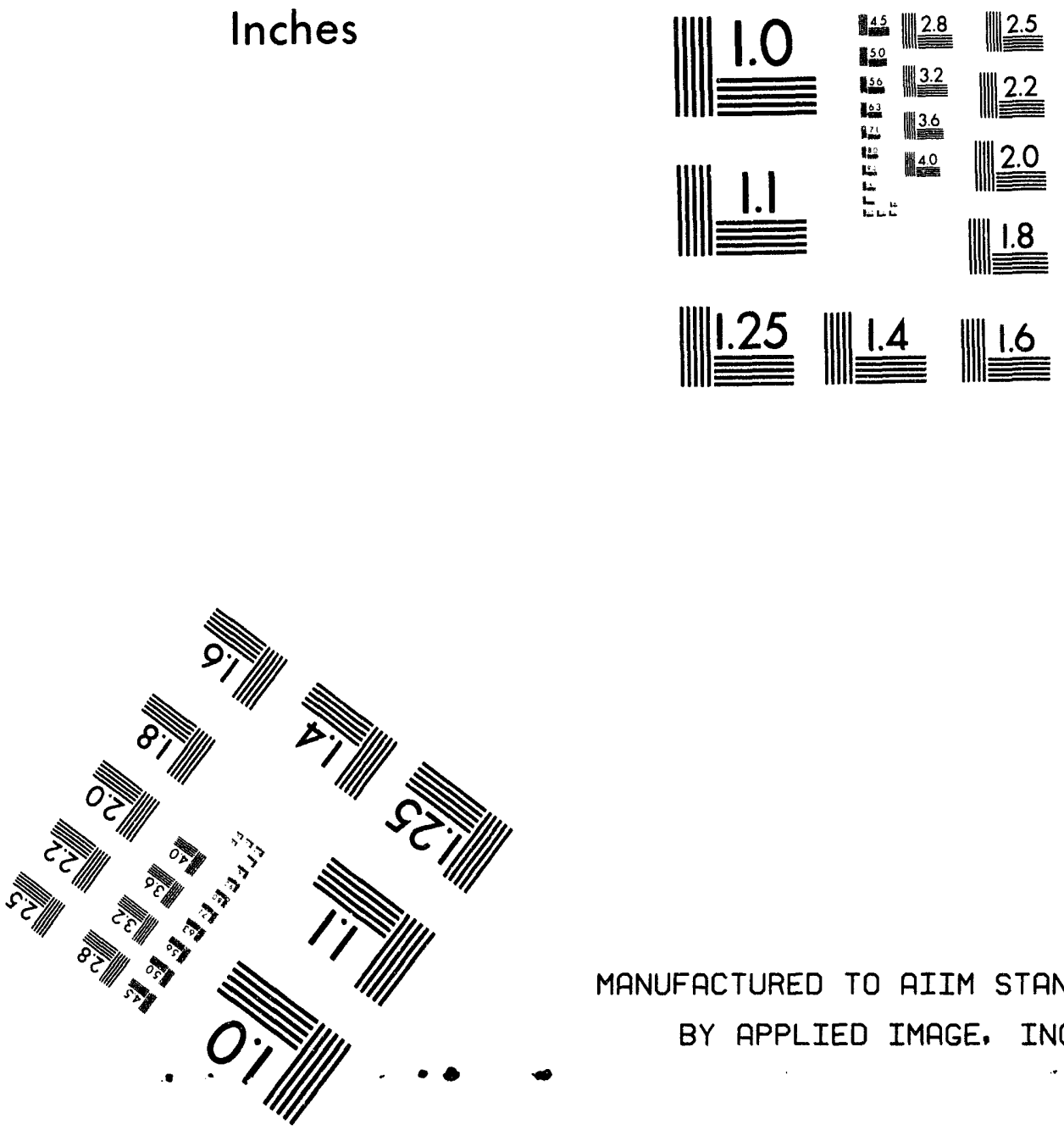

MANUFACTURED TO AIIM STANDARDS BY APPLIED IMAGE. INC.

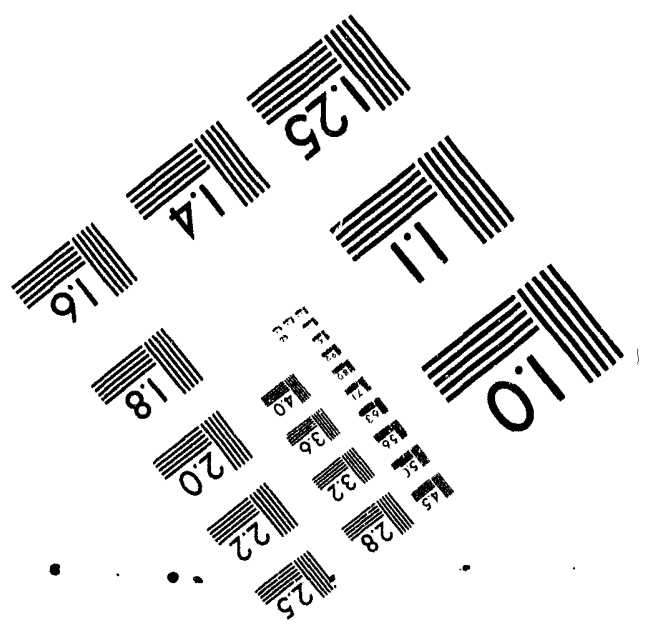



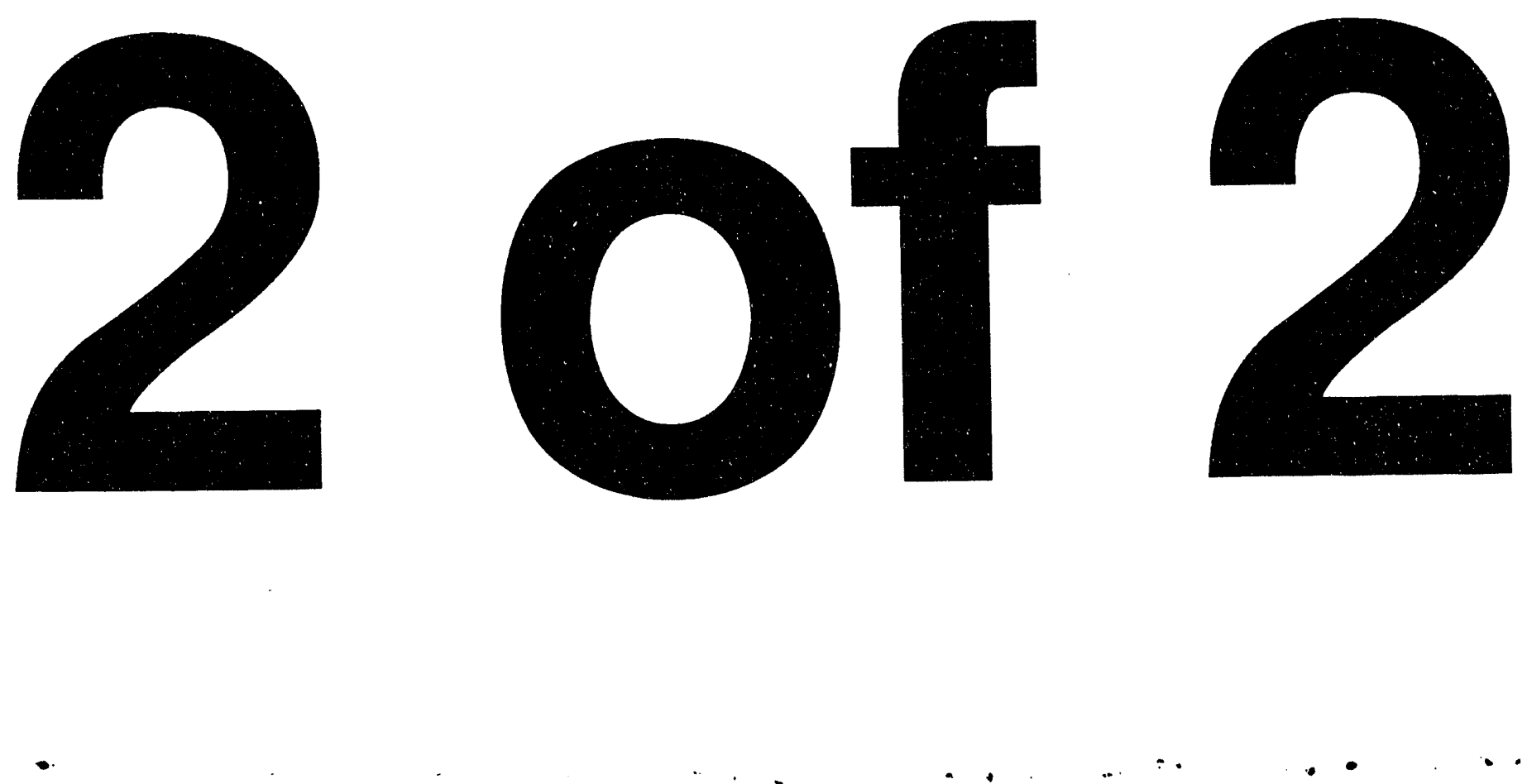
Brown, D. E., 1982. Biotic Communities of the American Southwest United States and Mexico: Desert Plants, University of Arizona, vol. 4, no. 1-4.

Bryan, K., 1909. Geology of the Vicinity of Albuquerque, University of New Mexico Bulletin 51, Geological Series, vol. 3, 24 pp.

Bryan, K., 1938. Geology and Groundwater Conditions of the Rio Grande Depression in Colorado and New Mexico, In U.S. Natural Resources Planning Board, Rio Grande Joint Investigations in the Upper Rio Grande Basin, U.S. Government Printing Office, Washington, D.C., vol. 1, pt. 2, pp. 197-225.

Bryan, K., and F. T. McCann, 1938. The Ceja del Rio Puerco, a Border Feature of the Basin and Range Province in New Mexico, pt. 2, Geomorphology, Jour. Geology, vol. 46 , no. 1, pp. 1-16, 5 figs.

Buol, S. W., F. D. Hole, and R. J. McCracken, 1989. Soil Genesis and Classification, 3d ed., Ames, Iowa: Iowa State University Press.

Cavin, W. J., J. R. Connolly, D. L. Edwards, M. Parchman, and L. A. Woodward, 1982. Precambrian Stratigraphy of Manzanita and North Manzano Mountains, New Mexico, New Mexico Geological Society Guidebook, 33d Field Conference, Albuquerque Country II, pp. 191-196.

Chapin, C. E., 1988. Axial Basins of the Northern and Central Rio Grande Rifts, in L. L. Sloss (ed.), Sedimentary Cover: North American Craton (U.S.), Geological Society of America, Geology of North America, vol. D-2, pp. 165-170.

Chapin, C. E., W. E. Elston, and H. L. James (eds.), 1978. Field Guide to Selected Cauldrons and Mining Districts of the Datil-Mogollon Volcanic Field, New Mexico, New Mexico Geological Society Special Publication 7, 149 pp.

Connolly, R., L. A. Woodward, and J. W. Hawley, 1982. Road-Log Segment I-1: Albuquerque to Tijeras Canyon, New Mexico Geological Society Guidebook 33, pp. 2-5.

Cordell, L. E., 1976. Aeromagnetic and Gravity Studies of the Rio Grande Graben in New Mexico Between Belen and Pilar, in Tectonics and Mineral Resources of Southwestern New Mexico, New Mexico Geological Society Special Publication 6, pp. 62-70, 10 figs.

Cordell, L. E., 1978. Regional Geophysical Setting of the Rio Grande Rift, Geological Society of America Bulletin, vol. 89, no. 7.

Cordell, L. E., H. R. Joesting, and J. E. Case, 1973. Complete Bouguer Anomaly Gravity Map of the Albuquerque-Grants Area, New Mexico, U.S. Geologic Survey Open-File map, 1 sheet. 
Cordell, L. E., G. R. Keller, and T. G. Hildenbrand, 1978. Complete Bouguer Gravity Anomaly Map of the Rio Grande Rift, U.S. Geological Survey Open-File Report 78-958.

Cordell, L., G. R. Keller, and T. G. Hildebrand, 1982. Bouguer Gravity Map of the Rio Grande Rift, Colorado, New Mexico, and Texas, U.S. Geological Survey Geophysical Investigations Map GP-949, scale 1:1,000,000.

DOE (U.S. Department of Energy), 1987. Comprehensive Environmental Assessment and Response Program, Phase I: Installation Assessment, Sandia National Laboratories, U.S. Department of Energy, Albuquerque Operations Office (Environment, Safety, and Health), Albuquerque, NM.

Fenneman, M. N., 1931. Physiography of the Western United States, New York: McGrawHill, $534 \mathrm{pp}$.

Goodrich, M., 1992. Report on a Surface Gravity Survey for Fault Delineation and Hydrogeologic Characterization, IT Corporation, Albuquerque, NM.

Grant, P. R., 1981. Geothermal Potential on Kirtland Air Force Base Labs, Bernalillo County, New Mexico, SAND81-7141, Sandia National Laboratories, Albuquerque, NM.

Grant, P. R., 1982. Geothermal Potential in the Albuquerque Area, New Mexico, New Mexico Geological Society Guidebook 33, pp. 325-331.

Hacker, L. 1977, Soil Survey of Bernalillo County and Parts of Sandoval and Valencia Counties, New Mexico, U. S. Department of Agriculture, Washington, D.C.

Hawley, J. W. (ed.), 1978. Guidebook to Rio Grande Rift in New Mexico and Colorado, New Mexico Bureau of Mines and Mineral Resources Circular 163, 241 pp.

Hawley, J. W., 1986. Physiographic Provinces of New Mexico, in J. L. Williams (ed.), New Mexico in Maps, 2d ed., University of New Mexico, Albuquerque, pp. 23-27.

Hawley, J. W., and C. S. Haase (eds.), 1992. Hydrogeologic Framework of the Northern Albuquerque Basin, New Mexico Bureau of Mines and Mineral Resources Open-File Report 387.

Hawley, J. W., and D. W. Love, 1991. Quaternary and Neogene Landscape Evolution: A Transect Across the Colorado Plateau and Basin and Range Provinces in West-Central and Central New Mexico, New Mexico Bureau of Mines and Mineral Resources, Bulletin 137, pp. 105-148. 
Hawley, J. W., G. O. Bachman, and K. Manley, 1976. Quaternary Stratigraphy in the Basin and Range and Great Plains Provinces, New Mexico and Western Texas, in W. C. Mahaney (ed.), Quaternary Stratigraphy of North America, Stroudsburg, Pennsylvania: Dowden, Hutchison, and Ross, pp. 235-274.

Heywood, C. E., 1992. Isostatic Residual Gravity Anomalies of New Mexico, New Mexico State Engineer Office, U.S. Geological Survey, Water-Resources Investigations Report 91-4065.

Heywood, C. E., 1993. Geophysicist, U.S. Geological Survey, Albuquerque Office, personal communication, Albuquerque, NM.

Hyndman, D. A., 1992. A Ground Conductivity and Magnetometer Survey at the Mixed Waste Landfill, Technical Area III, Sandia National Laboratories, Sunbelt Geophysics, Albuquerque, NM.

Ingersoll, R. V., W. Cavazza, W. S. Baldridge, and M. Shafiqullah, 1990. Cenozoic Sedimentation and Paleotectonics of North-Central New Mexico: Implications for Initiation and Evolution of the Rio Grande Rift, Geological Society of America Bulletin 102, pp. 1280-1296.

IT (International Technology Corporation), 1992. Geologic Mapping of the Sanitary Sewer Line Excavation, Southern Sandia National Laboratories, Albuquerque, NM, Contractor Report to SNL/NM ER Program, SWHC/4.0001.

Jiracek, G. R., E. P. Gustafson, and M. D. Parker, 1982. Geophysical Exploration for Geothermal Prospects West of Albuquerque, New Mexico, New Mexico Geological Guidebook, 33d Field Conference.

Kelley, V. C., 197\%. Geology of Albuquerque Basin. New Mexico, New Mexico Bureau of Mines and Mineral Resources Memoir 33, 59 pp.

Kelley, V. C., 1982a. Albuquerque: Its Mountains, Valleys, Water, and Volcanoes, New Mexico Bureau of Mines and Mineral Resources, Scenic Trips to the Geological Past No. 9, 106 pp.

Kelley, V. C., 1982b. Diverse Geology of the Hubbell Bench. Albuquerque Basin, New Mexico, in New Mexico Geological Society Guide, 33d Field Conference, Albuquerque Country II, pp. 159-161.

Kelley, V. C., and S. A. Northrop, 1975. Geology of Sandia Mountains and Vicinity, New Mexico, New Mexico Bureau of Mines and Mineral Resources Memoir 29, 136 pp., 92 figs.

Krumhansl, J. L., and V. S. McConnell, in preparation. Geology of the Central Kirtland Air Force Base and the Travertine Hills, SAND93-0683, Sandia National Laboratories, Albuquerque, NM. 
Kues, B. S., S. Lucas, and R. V. Ingersol, 1982. Lexicon of Phanerozoic Stratigraphic Names Used in the Albuquerque Area, New Mexico Geological Society Guidebook, 33d Field Conference, Albuquerque Country II, pp. 125-138.

Lambert, P. W., 1968. Quaternary Stratigraphy of the Albuquerque Area, New Mexico, New Mexico University, Albuquerque, unpublished Ph.D. dissertation, 329 pp., 25 figs.

Lambert, P. W., 1974. Map showing present and potential sources of blowing sand in La Mesita Negra southeast quadrangle, Bernalillo County, New Mexico, U.S. Geological Survey Miscellaneous Field Studies Map MF-600, scale 1:24,000.

Lambert, P. W., J. W. Hawley, and S. G. Wells, 1982. Supplemental Road-Log Segment III-S: Urban and Environmental Geology of the Albuquerque Area, New Mexico Geological Society Guidebook 33, pp. 97-119.

Lisenbee, A. L., L. A. Woodward, and J. R. Connolly, 1979. Tijeras-Canoncito Fault System: A Major Zone of Recurrent Movement in North Central New Mexico, in New Mexico Geological Society Guidebook, 30th Annual Field Conference, Santa Fe County, NM.

Lozinsky, R. P., 1988. Stratigraphy, Sedimentology, and Sand Petrology of the Santa Fe Group and pre-Santa Fe Tertiary Deposits in the Albuquerque Basin. Central New Mexico, unpublished Ph.D. dissertation, New Mexico Institute of Mining and Technology, Socorro, NM, 298 pp.

Lozinsky, R. P., and R. H. Tedford, 1991. Geology and Paleontology of the Santa Fe Group, Southwestern Albuquerque Basin. Valencia County, New Mexico, New Mexico Bureau of Mines and Mineral Resources Bulletin 132, 35 pp.

Lozinsky, R. P., J. W. Hawley, and D. W. Love, 1991. Geologic Overview and PlioceneQuaternary History of the Albuquerque Basin. Central New Mexico, New Mexico Bureau of Mines and Minerals Resources Bulletin 137, pp. 157-162.

Machette, M. N., 1978a. Geologic Map of the San Acacia Quadrangle, Socorro County, New Mexico, U.S. Geological Survey Geologic Quadrangle Map GQ-1415, scale $1: 24,000$.

Machette, M. N., 1978b. Preliminary Geologic Map of the Socorro $1^{\circ}$ by $2^{\circ}$ Quadrangle, Central New Mexico. U.S. Geological Survey Open-File Report 78-607.

Machette, M. N., 1978c. Preliminary Geologic Map of the Socorro $1^{\circ}$ by $2^{\circ}$ Quadrangle, Central New Mexico, U.S. Geological Survey Open-File Report 78-607.

Machette, M. N., 1982. Quaternary and Pliocene Faults in the La Jencia and Southern Part of the Albuquerque-Belen Basins, New Mexico: Evidence of Fault History from FaultScarp Morphology and Quaternary Geology, New Mexico Geological Society Guidebook 33, pp. 161-169. 
Machette, M. N., 1985. Calcic Soils of the Southwestern United States, Geological Society of America Special Paper 203, pp. 1-21.

Maynard, S. R., L. A. Woodward, and D. L. Giles, 1991. Tectonics, Intrusive Rocks, and Mineralization of the San Pedro-Ortiz Prophyry Belt. North-Central New Mexico, New Mexico Bureau of Mines and Mineral Resources Bulletin 137, pp. 57-69.

McCord, J. T., D. Crowson, R. Holt, J. Piper, and E. K. Webb, 1993. Detailed Mapping and Preliminary Geostatistical Analysis of Alluvial Fan Deposits Exposed in Six Miles of Trench, SAND93-0680, in preparation, Sandia National Laboratories, Albuquerque, NM.

Myers, D. A., 1973. The Upper Paleozoic Madera Group in the Manzano Mountains, New Mexico, U.S. Geological Survey Bulletin 1372-F, 13 pp.

Myers, D. A., 1982. Stratigraphic Summary of Pennsylvanian and Lower Permian Rocks, Manzano Mountains, New Mexico, in New Mexico Geological Society Guidebook, 33d Field Conference, Albuquerque Country II, pp. 233-237.

Myers, D. A., and E. J. McKay, 1970. Geologic Map of the Mount Washington Quadrangle, Bernalillo and Valencia Counties, New Mexico, U.S. Geological Survey Geologic Quadrangle Map GQ-886.

Myers, D. A., and E. J. McKay, 1971. Geologic Map of the Bosque Peak Quadrangle, Torrance, Valencia, and Bernalillo Counties, New Mexico, U.S. Geological Survey Geologic Quadrangle Map GQ-948.

Myers, D. A., and E. J. McKay, 1976. Geologic Map of the North End of the Manzano Mountains, Tijeras and Sedillo Quadrangles, Bernalillo County, New Mexico, U.S. Geological Survey Miscellaneous Geologic Investigations Map I-968.

Naval Research Laboratory, 1992. Magnetometry and Radar Evaluation of Toxic and Hazardous Waste Sites at Sandia National Laboratories, 1992: Developing Technology for Environmental Restoration, Final Report.

Peace, C. 1993. Task Leader, Sandia National Laboratories Environmental Restoration Program, personal communication, Sandia National Laboratories, Albuquerque, NM.

Read, C. B., R. H. Wilpot, D. A. Andrews, C. H. Summerson, and G. H. Wood, 1944. Geologic Map and Stratigraphic Sections of Permian and Pennsylvanian Rocks of Parts of San Miguel, Santa Fe, Sandoval, Bernalillo, Torrance, Valencia Counties, NorthCentral New Mexico, U.S. Geological Survey Oil and Gas. Inv. Prelim. Map 21.

Reiche, P., 1949. Geology of the Manzanita and North Manzano Mountains, New Mexico. Geologic Society of America Bulletin, vol. 60, no. 7, pp. 1183-1212, 5 figs. 
Riddle, L., and P. R. Grant, 1981. Geothermal Potential on Kirtland Air Force Base Labs, Bernalillo County. New Mexico, SAND81-7141, Sandia National Laboratories, Albuquerque, NM.

Riddle, L., and B. Grant, 1981. Geothermal Studies at Kirtland Air Force Base, Albuquerque, New Mexico, SAND81-0852, Sandia National Laboratories, Albuquerque, NM.

Russell, L. R., and S. Snelson, 1990. Structural Style and Tectonic Evolution of the Albuquerque Basin Segment of the Rio Grande Rift, in B. Pinet and C. Bois (eds.), Potential for Deep Seismic Profiling for Hydrocarbon Exploration, Paris: Editions Technip, French Petroleum Institute Research Conference Proceedings, pp. 175-207.

Saucier, G., S. G. Wells, and B. S. Kues, 1982. Stratigraphic Nomenclature Chart, New Mexico Geological Society Guidebook 33, p. x.

Sigma Geoservices, Inc., 1984. Seismic Reflection Survey on Kirtland Air Force Base, New Mexico.

Smith, L. N., T. F. Bullard, and S. G. Wells, 1982. Quaternary Geology and Geomorphology of Tijeras Canyon, New Mexico, New Mexico Geological Society, Guidebook 33, pp. 5-7.

Soil Survey Staff, 1975. Soil Taxonomy: A Basic System of Soil Classification for Making and Interpreting Soil Survey, U.S. Department of Agriculture, Soil Conservation Service, Agriculture Handbook No. 436, Washington, D.C., U.S. Government Printing Office, $754 \mathrm{pp}$.

Soil Survey Staff, 1981. Replacement chapter to Handbook 18, Soil Survey Manual, released May 1981, U.S. Department of Agriculture, Soil Conservation Service.

Spiegel, Z., and B. Baldwin, 1963. Geology and Water Resources of the Santa Ana Area, New Mexico, U.S. Geological Survey Water-Supply Paper 1525, 258 pp.

Weston, R. F. Inc., 1984. Characterization of the Sandia National Laboratories (SNLA) Chemical Waste Disposal Site, Albuquerque, New Mexico, Weston Inc., no. 2143-02-01.

Woodward, L. A., 1982. Tectonic Framework of Albuquerque Country, New Mexico Geological Society Guidebook, 33d Field Conference, Albuquerque Country II, pp. 141-145.

Woodward, L. A., J. F. Callender, and J. Gries, 1975. Tectonic Map of the Rio Grande Region, Colorado-New Mexico Border to Presidio, Texas, in Guidebook to Las Cruces Country, New Mexico Geological Society, 26th Field Conference, p. 239. 
Woodward, L. A., M. A. Parchman, D. L. Edwards, and J. W. Husler, 1979. Stratigraphy and Mineralization of Hell Canyon Greenstone Belt (Precambrian), New Mexico Geological Society Guidebook 30, pp. 189-195.

USDA (United States Department of Agriculture), 1960. Soil Classification: A Comprehensive System, 7th approximation, $265 \mathrm{pp}$. 


\subsection{HYDROLOGIC SETTING}

This section provides a summary description of the current state of knowledge of the SNL/KAFB hydrologic setting. This summary description includes information obtained from all appropriate reports and from ER Program studies and projects. The hydrologic setting is interrelated with the local geologic framework (see Section 3.0) and includes the meteorological environment (precipitation and evaporation), surface water run-off, percolation through the vadose zone, and saturated groundwater flow. The objective of this section is to summarize the current understanding-and the associated uncertainties-of the occurrence, movement, and interaction of surface and subsurface water. Meeting this objective will help establish a quantitative understanding of potential pathways for transport of contaminants from SNL/KAFB sites to receptors that could lead to adverse impacts to human and environmental health and safety.

\subsection{Meteorology}

Local climatic conditions play a major role in the overall hydrologic setting for the $\mathrm{SNL} / \mathrm{KAFB}$ area. This section describes the climatic setting and climatic data for this area.

\subsubsection{Summary of Climate}

KAFB is situated on an alluvial plain on the eastern slopes of the Rio Grande Valley. The climate of this area is typical of a high desert plateau: low precipitation and wide temperature extremes. The days are typically sunny with few clouds; there are an average of 169 clear days per year.

The average precipitation at the Albuquerque International Airport is 8.8 in. $(22 \mathrm{~cm})$ per year (NOAA 1993). The airport is located at the far northwestern edge of KAFB at an elevation of $5,311 \mathrm{ft}(1,619 \mathrm{~m})$. The majority of the base is at higher elevations, ranging to about $8,000 \mathrm{ft}(2,440 \mathrm{~m})$ in the Manzano Mountains near the southeastern edge. The average precipitation increases with elevation eastward across KAFB to nearly 20 in. $(51 \mathrm{~cm})$ per year at the higher elevations (U.S. Weather Bureau, no date) (Figure 4-1).

The majority of the precipitation occurs during June through October in the form of heavy thunderstorms, with one-third of the annual rainfall occurring during July and August. There are an average of 41 thunderstorms per season (NOAA 1990). The average monthly precipitation is less than 0.5 in. $(1.3 \mathrm{~cm})$ in the winter and 1.5 in. $(3.8 \mathrm{~cm})$ in the summer. The average annual snowfall for Albuquerque is 14.7 in. $(37.3 \mathrm{~cm}$ ) (NOAA 1990). Snow rarely remains on the ground for more than 24 hours at the lower elevations, but a snow cover in the mountains is common from mid-November to early spring for the SNL/KAFB area.

The average annual temperature in Albuquerque is $56^{\circ} \mathrm{F}\left(13^{\circ} \mathrm{C}\right)$, with an average diurnal temperature range of $28^{\circ} \mathrm{F}\left(16^{\circ} \mathrm{C}\right)$ (NOAA 1990). The average daily temperature range is -broad, "bot extreme temperatures are rare. "Average daily temperatires of the SNL/KAFB area in the winter range from 23 to $52^{\circ} \mathrm{F}\left(-5\right.$ to $\left.11^{\circ} \mathrm{C}\right)$ and from 57 to $91^{\circ} \mathrm{F}\left(14\right.$ to $\left.33^{\circ} \mathrm{C}\right)$ in 


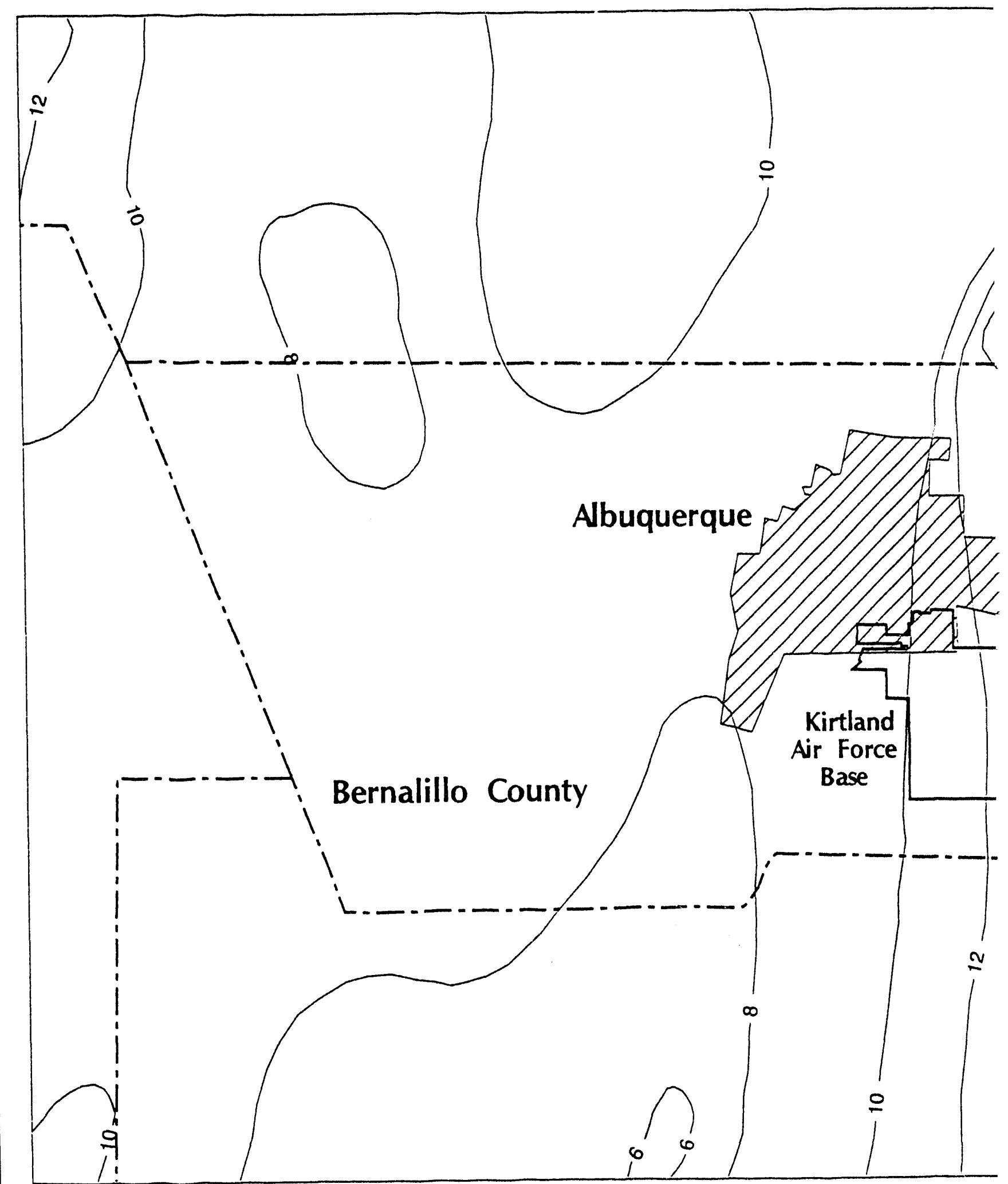

Figure 4-1. Áverage Preoipitation 


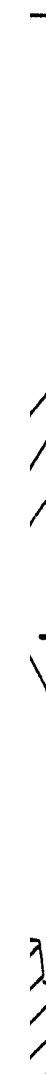

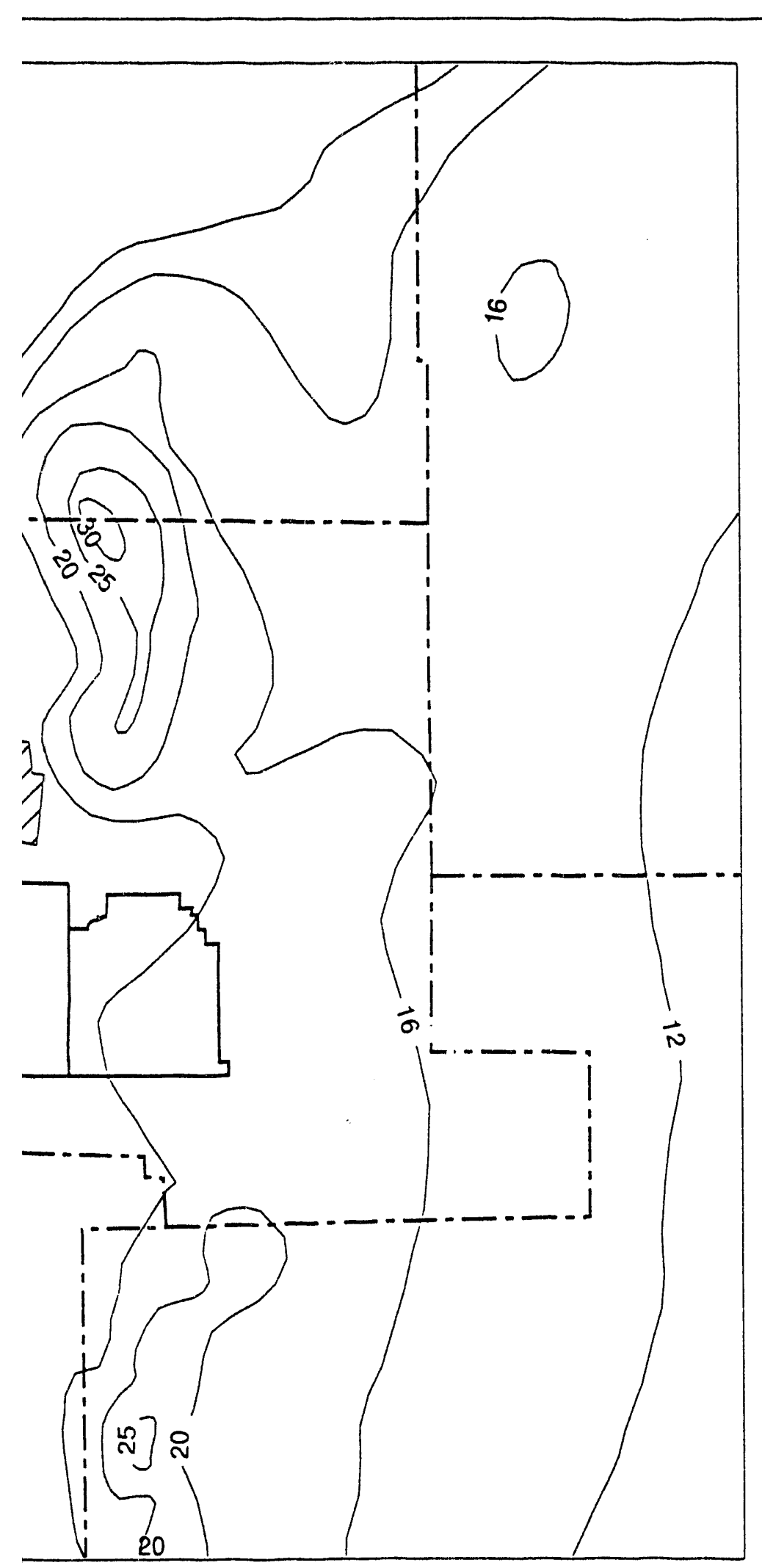

N Birtland Air Force Base Boundary

P' County Boundaries

$\bigwedge \begin{aligned} & \text { lsohyet of Average Precipitation } \\ & \text { in Inches }\end{aligned}$

77 Ciny of Abuquerque

$n$ the SNL/KAFB and Aibuquerque Area 
the summer. The temperature is expected to be greater than $90^{\circ} \mathrm{F}\left(30^{\circ} \mathrm{C}\right)$ for an average of 63 days per year, mainly during May through September.

Freezing temperatures occur on an average of 119 days per year, from November to early April. Extremely cold temperatures are very rare; temperatures below $0^{\circ} \mathrm{F}\left(-18^{\circ} \mathrm{C}\right)$ occur on a frequency of less than once per year. The average number of frost-free days is 190 in the valley and 120 in the mountains.

The average annual wind speed for the Albuquerque area is $9 \mathrm{mph}(4 \mathrm{~m} / \mathrm{s})$. Sustained winds of $12 \mathrm{mph}(5.4 \mathrm{~m} / \mathrm{s})$ or less occur approximately 80 peicent of the time at the Albuquerque Internationai Airport, whereas sustained winds greater than $25 \mathrm{mph}(11.2 \mathrm{~m} / \mathrm{s})$ have a frequency of less than 3 percent (NOAA 1990). Winds blow most frequently from the north in winter and from the south along the river valley in summer. Winds are generally stronger in the late winter and early spring months, and occasionally dusty days occur due to blowing soils. The prevailing winds at SNL/KAFB are from the east, although winter winds at a level $100 \mathrm{ft}(30.5 \mathrm{~m})$ above the surface are from the north (Olsen et al. 1970).

The air is normally dry, with an average annual relative humidity for Albuquerque of about 44 percent. The average diurnal range is from nearly 60 percent in the morning to 2 ? percent in the afternoon (NOAA 1990). Bonzon et al. (1974) estimated the average annual relative humidity for the SNL/KAFB area to be 46 percent, with an annual range of 10 to 70 percent. Evapotranspiration in the area has been estimated at 95 percent of the annual rainfall (Thomson and Smith 1985).

\subsubsection{Meteorological Monitoring}

There is currently no organized monitoring of meteorology on KAFB. There is a National Oceanic Atmospheric Administration (NOAA) meteorological station at the Albuquerque International Airport on the edge of KAFB, and there are plans to set up a network of ten meteorological stations within KAFB. The NOAA operates a first-class meteorological station at the Albuquerque International Airport $[5,311 \mathrm{ft}(1,619 \mathrm{~m})]$. This station collects data on temperature, dew point, surface wind $[20 \mathrm{ft}(6.1 \mathrm{~m})]$, atmospheric pressure, precipitation, visibility, and cloud cover. These data are recorded hourly.

As a part of the air quality monitoring program, SNL/NM Department 7725 , in cooperation with Department 6612, is planning to set up a program to monitor wind speed, wind direction, and air temperature from three $98-\mathrm{ft}(30-\mathrm{m})$ towers and seven $33-\mathrm{ft}(10-\mathrm{m})$ towers. Both the $33-\mathrm{ft}(10-\mathrm{m})$ and the $98-\mathrm{ft}(30-\mathrm{m})$ sites will measure these data at the $33-\mathrm{ft}(10-\mathrm{m})$ level; the $98-\mathrm{ft}(30-\mathrm{m})$ sites will additionally monitor wind speed and direction and air temperature at the $98-\mathrm{ft}(30-\mathrm{m})$ level. Two of the $33-\mathrm{ft}(10-\mathrm{m})$ sites will measure rainfall. These sites will be located within the KAFB boundary, from TA-I to the "Schoolhouse" site near Arroyo del Coyote; none will be located in the USFS withdrawn area. All sites will record data onto a Campbell CR10 data logger and will be connected to a central facility by phone. Data collection at these sites is scheduled to begin test-phase operation in the spring of 1993, with full data collection scheduled to begin on October 1, 1993. 
A portable Doppler acoustic sounder will be available to monitor wind speed and direction over a vertical profile. This unit is expected to be used primarily at the Burn Site in Lurance Canyon, but could be used wherever a vertical wind profile is needed.

A network of seven meteorological towers surrounding SNL/NM-operated nuclear reactors was operated for 10 yrs beginning in July of 1960; an eighth station was added in May of 1965 (Olsen et al. 1970). This network is no longer in operation.

\subsubsection{Additional Data or Studies Needed}

A dedicated network of rain gauges is needed to characterize rainfall distribution in the SNL/KAFB area. These data will be used to support recharge estimates for groundwater modeling and to calibrate surface water-models. Presently, SNL/NM Department 7725 plans to install two rain gauges, but locations have not been selected.

\subsection{Surface Water Hydrology}

The surface water system within the SNL/KAFB area consists primarily of ephemeral drainages. These drainages probably experience channel loss and thus contribute to groundwater recharge. Of additional concern is the possible erosion and subsequent surface transport and redistribution of contaminants.

\subsubsection{Surface Water Setting}

The major surface hydrologic feature in central New Mexico is the Rio Grande, which flows north to south through the Albuquerque Valley. The SNL/KAFB area lies approximately $5 \mathrm{mi}(8 \mathrm{~km})$ east of the Rio Grande. Average flow in the Rio Grande at Albuquerque from 1974 through 1991 (subsequent to the closing of Cochiti dam) was $1,020,000 \mathrm{acre}-\mathrm{ft} / \mathrm{yr}(12.6$ x $10^{8} \mathrm{~m}^{3} / \mathrm{yr}$ ) (USGS 1992).

The major surface drainage feature in the SNL/KAFB area is Tijeras Arroyo, which flows westward from the Sandia and Manzano Mountains to the Rio Grande (Figure 4-2). Tijeras Arroyo at a point just downstream of the KAFB boundary drains a $126-\mathrm{mi}^{2}\left(326-\mathrm{km}^{2}\right)$ area that includes some urban run-off from city flood channels, Tijeras Canyon, and the 39-mi ${ }^{2}$ $\left(101-\mathrm{km}^{2}\right)$ Arroyo del Coyote drainage. The Arroyo del Coyote drainage includes Lurance Canyon, Madera Canyon, and much of the Manzano Base area. The major part of the Tijeras Arroyo watershed lies to the north and east of KAFB, whereas the Arroyo del Coyote watershed is within SNL/KAFB.

A third watershed lies within KAFB to the south of the Arroyo del Coyote watershed. The channel for this drainage divides and spreads out soon after it reaches the alluvial fan, and flow appears to seldom reach the Rio Grande. Arroyo del Coyote, Tijeras Arroyo, and all surface water features in KAFB are ephemeral streams, with the exception of small portions of Arroyo del Coyote near Coyote Springs and G Spring, which are intermittent. An ephemeral stream is one that flows only in response to rainfall and loses water to the water table. Tijeras Arroyo is also intermittent at a point $2 \mathrm{mi}(3.2 \mathrm{~km})$ upstream of the KAFB boundary. 


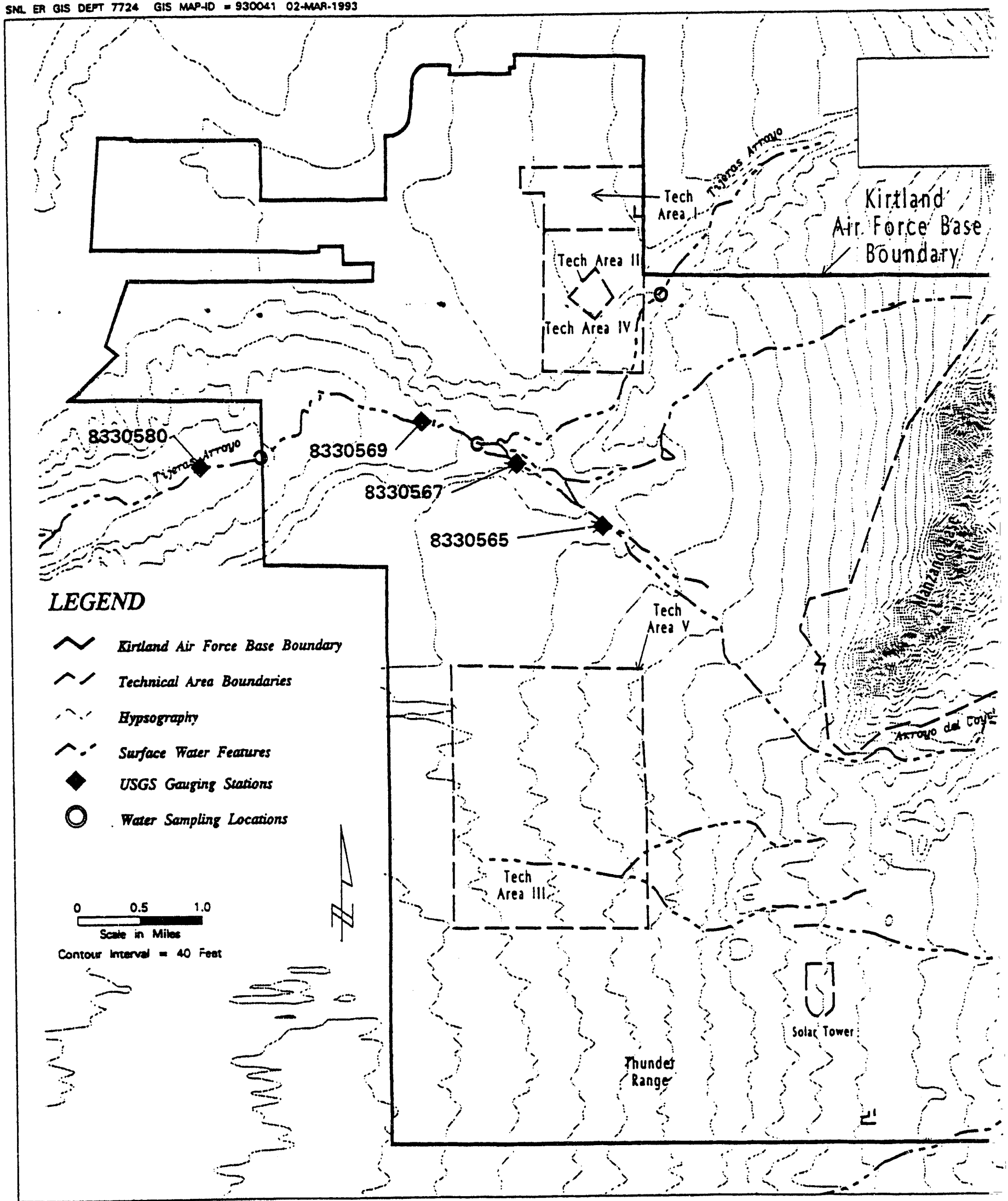

Figure 4-2. Surface Water Featur: 


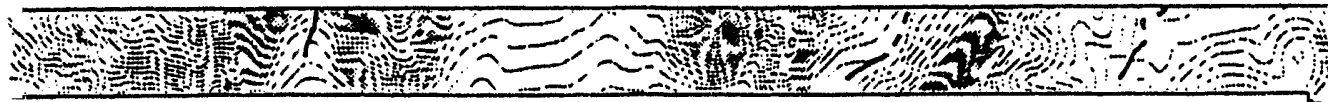

\section{Surface Water Features in the SNL/KAFB Area Based on Information Available as of January 1993}

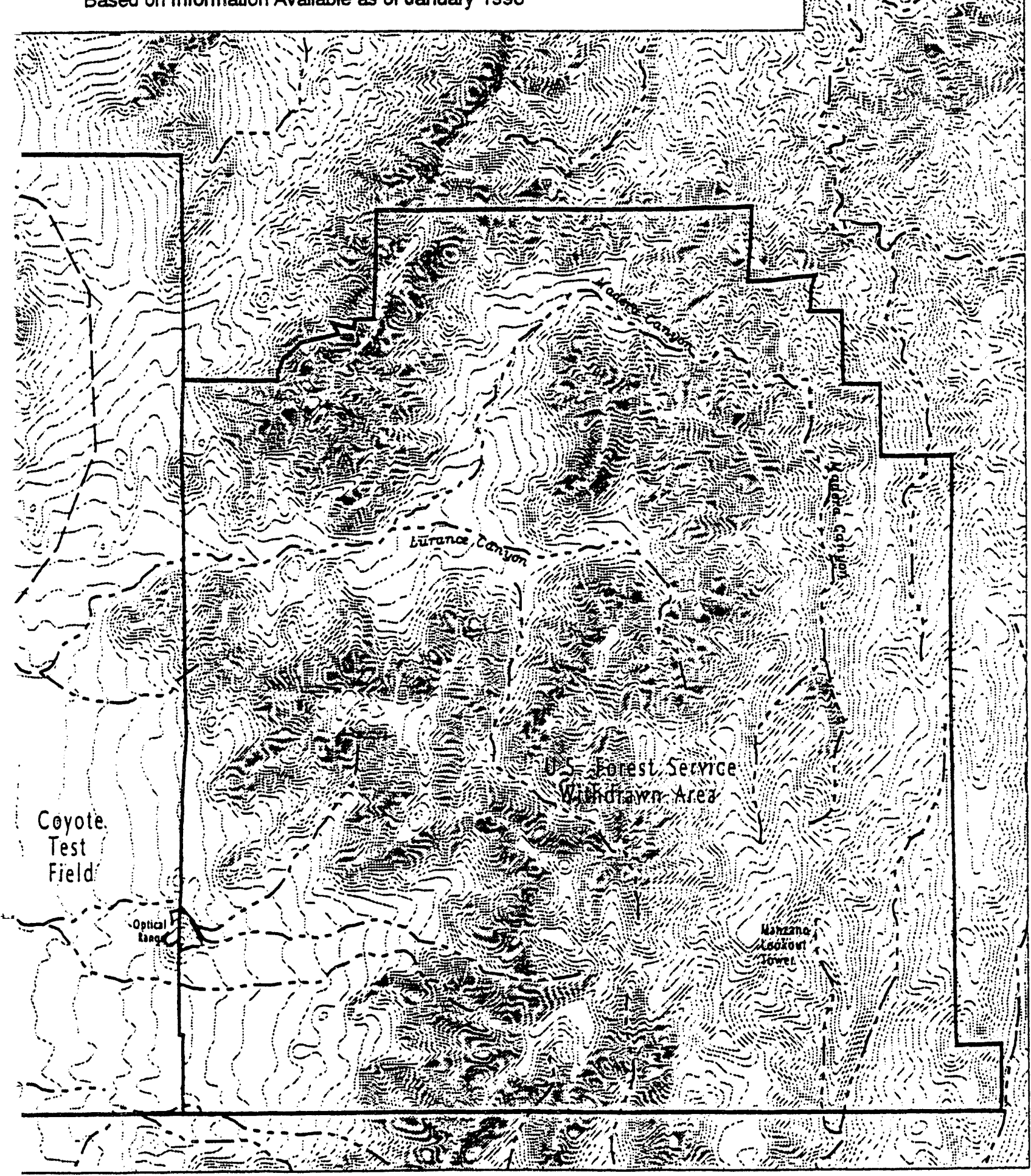

$s$ in the SNL/KAFB Area 
The upper reaches of these arroyos cut through mountainous terrain, with an average slope of about $130 \mathrm{ft} / \mathrm{mi}(25 \mathrm{~m} / \mathrm{km})$. As the arroyos enter onto the alluvial fan, bed slope decreases to an average of about $100 \mathrm{ft} / \mathrm{mi}(19 \mathrm{~m} / \mathrm{km})$.

Generally, floods and run-off occur almost exclusively during the summer thunderstorm season (July through September). Run-off occurs in response to the intense type of rainfall that occurs during thunderstorms. These floods are characterized by high peak flows, small volumes, and short durations. The low-intensity rain that occurs during winter or spring rarely produces run-off in the arroyos. The snow in the Manzano Mountains can produce local run-off in the mountains, but only rarely does the run-off reach the lower portions of the arroyos or the Rio Grande.

The U.S. Army Corps of Engineers (COE) assessed the extent of flooding to be expected from 100-yr and 500-yr floods and has mapped the areas that will be inundated by those floods on maps at a scale of $1 \mathrm{in} .=200 \mathrm{ft}(1 \mathrm{~cm}=24 \mathrm{~m})$, with $2-\mathrm{ft}(0.6-\mathrm{m})$ contour intervals (COE 1979). Figure 4-3 shows the flood plain of the 500-yr flood at a scale of 1 in. $=4,000 \mathrm{ft}(1 \mathrm{~cm}=480 \mathrm{~m})$. The 100-yr flood is not shown in Figure 4-3 because it is not discernible from the 500-yr flood at this scale. The discharges computed by the COE for the 10-yr, 50-yr, 100-yr, and 500-yr floods at Tijeras Arroyo and Arroyo del Coyote are shown in Table 4-1. These discharges were computed partly on the basis of stream-flow records and partly through the use of synthetic unit hydrographs.

It has recently come to our attention that there are at least three additional flood studies that have been done in the SNL/KAFB area. Bovay Engineers (1981) did a drainage management plan for Tijeras Arroyo; Leedshill-Herkenhoff (1987) also did a drainage management plan for Tijeras Arroyo. Bohannan-Huston (1992) did a drainage system analysis for TA-I, TA-II, and TA-IV. McCann and Boissonnade (1988) assessed the flood potential at SNL/NM and found that SNL/NM facilities are not impacted by flooding.

There are two perennial springs in the Arroyo del Coyote drainage: Coyote Springs and Sol se Mete Spring. Other springs, G Spring, Burn Site Spring, and some localized seeps do not run continuously. Hubbell Spring is located on the Isleta Pueblo Indian Reservation south of KAFB. Thesc springs, with the exception of Hubbell Spring, are shown in Figure 4-4. There are no lakes or bodies of standing water on KAFB other than sewage lagoons.

\subsubsection{Surface Water Monitoring and Investigations}

A limited amount of surface water monitoring has taken place in the SNL/KAFB area since 1989. The USGS monitors four stream gauging stations in the KAFB area. These gauges are listed in the Table 4-2 and are shown in Figure 4-2 (USGS 1992). A summary of the data for these stations is presented in Table 4-3 (USGS 1992, 1993b). These gauges were originally installed as paired stations and were part of a USGS channel loss study.

In 1989 the USGS, in cooperation with the Albuquerque Metropolitan Arroyo Flood Control Authority, began a study to quantify channel loss and peak attenuation of flood flows in the Albuquerque area. The purpose of the study was to collect data that could be used to 


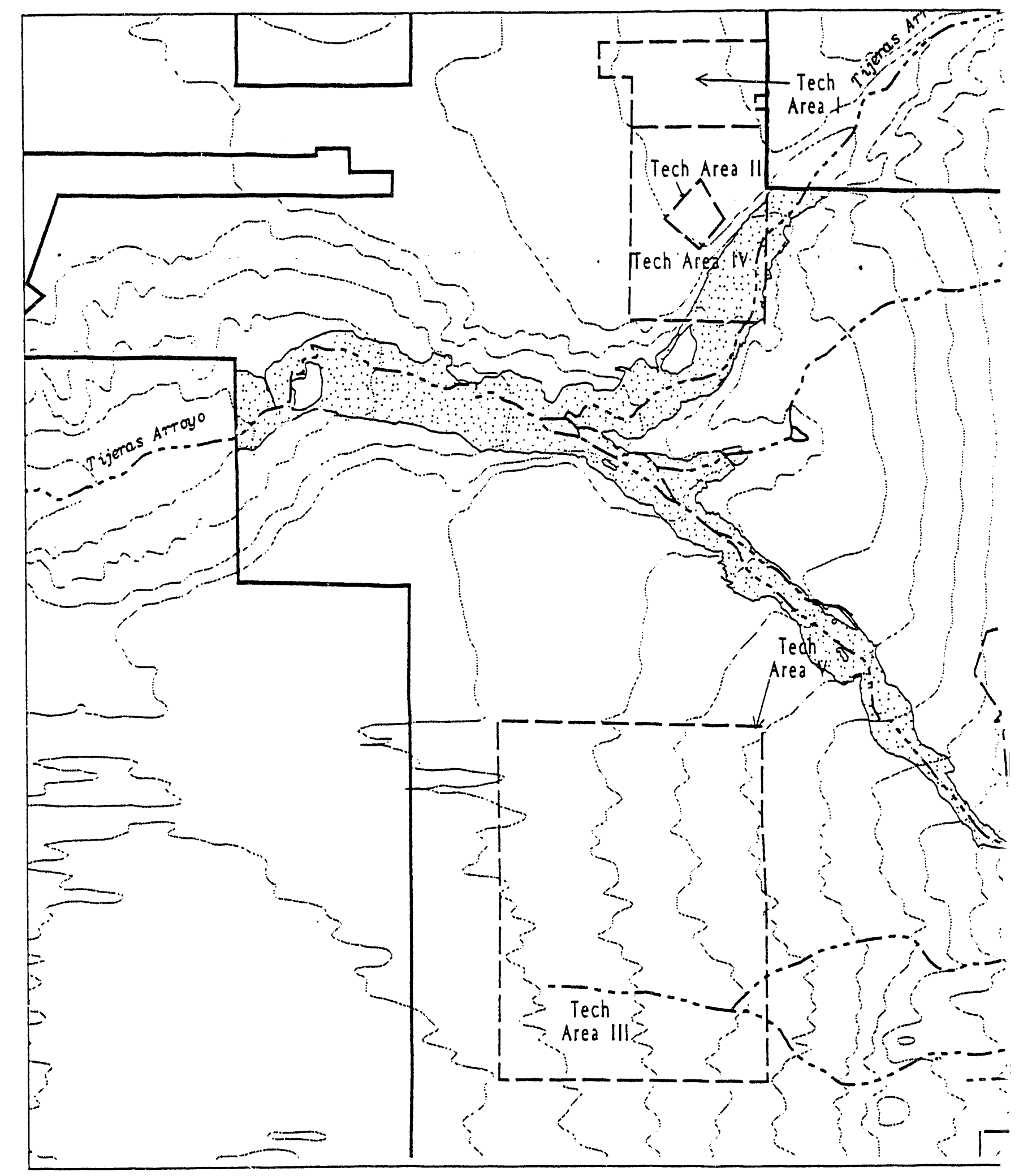

Figure 4-3. Flood-Prone Areas in Tijer: 


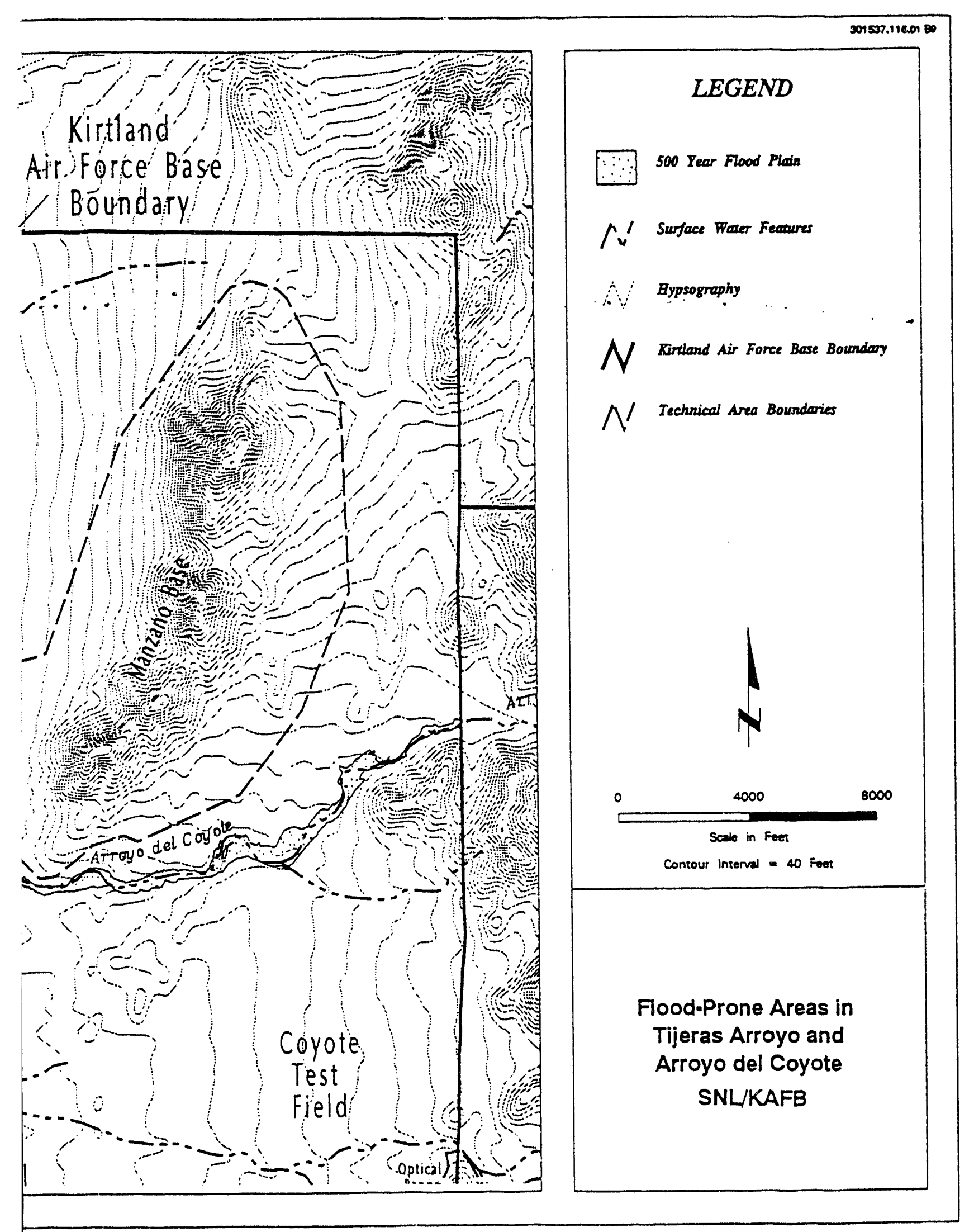

s Arroyo and Arroyo del Coyote SNL/KAFB 
Table 4-1

Peak Discharges for COE Flood Hazard Study (COE 1979)

\begin{tabular}{|c|c|c|c|c|}
\hline LOCATION & 10-YR FLOOD & 50-YR FLOOD & 100-YR FLOOD & 500-YR FLOOD \\
\hline $\begin{array}{l}\text { Arroyo del Coyote just } \\
\text { above confluence with } \\
\text { Tijeras Arroyo }\end{array}$ & $\begin{array}{l}2,160 \mathrm{ft}^{3} / \mathrm{s} \\
\left(61.2 \mathrm{~m}^{3} / \mathrm{s}\right)\end{array}$ & $\begin{array}{l}5,600 \mathrm{ft}^{3 / \mathrm{s}} \\
\left(159 \mathrm{~m}^{3} / \mathrm{s}\right)\end{array}$ & $\begin{array}{l}8,425 \mathrm{ft}^{3} / \mathrm{s} \\
\left(239 \mathrm{~m}^{3} / \mathrm{s}\right)\end{array}$ & $\begin{array}{c}18,900 \mathrm{ft}^{3} / \mathrm{s} \\
\left(535 \mathrm{~m}^{3} / \mathrm{s}\right)\end{array}$ \\
\hline $\begin{array}{l}\text { Tijeras Arroyo just } \\
\text { above confluence with } \\
\text { Arroyo del Coyote }\end{array}$ & $\begin{array}{l}4,850 \mathrm{ft}^{3} / \mathrm{s} \\
\left(137 \mathrm{~m}^{3} / \mathrm{s}\right)\end{array}$ & $\begin{array}{c}12,200 \mathrm{ft}^{3} / \mathrm{s} \\
\left(346 \mathrm{~m}^{3} / \mathrm{s}\right)\end{array}$ & $\begin{array}{c}17,300 \mathrm{ft}^{3} / \mathrm{s} \\
\left(490 \mathrm{~m}^{3} / \mathrm{s}\right)\end{array}$ & $\begin{array}{l}36,700 \mathrm{ft}^{3} / \mathrm{s} \\
\left(1040 \mathrm{~m}^{3} / \mathrm{s}\right)\end{array}$ \\
\hline $\begin{array}{l}\text { Tijeras Arroyo at } \\
\text { western edge of study } \\
\text { area }\end{array}$ & $\begin{array}{l}6,200 \mathrm{ft}^{3} / \mathrm{s} \\
\left(176 \mathrm{~m}^{3} / \mathrm{s}\right)\end{array}$ & $\begin{array}{c}16,050 \mathrm{ft}^{3} / \mathrm{s} \\
\left(455 \mathrm{~m}^{3} / \mathrm{s}\right)\end{array}$ & $\begin{array}{c}22,700 \mathrm{ft}^{3} / \mathrm{s} \\
\left(643 \mathrm{~m}^{3} / \mathrm{s}\right)\end{array}$ & $\begin{array}{l}47,800 \mathrm{ft}^{3} / \mathrm{s} \\
\left(1350 \mathrm{~m}^{3} / \mathrm{s}\right)\end{array}$ \\
\hline
\end{tabular}


SNL SR GIS DEFT 7724 GIS MAP-D = 930010 02.MAA-1993

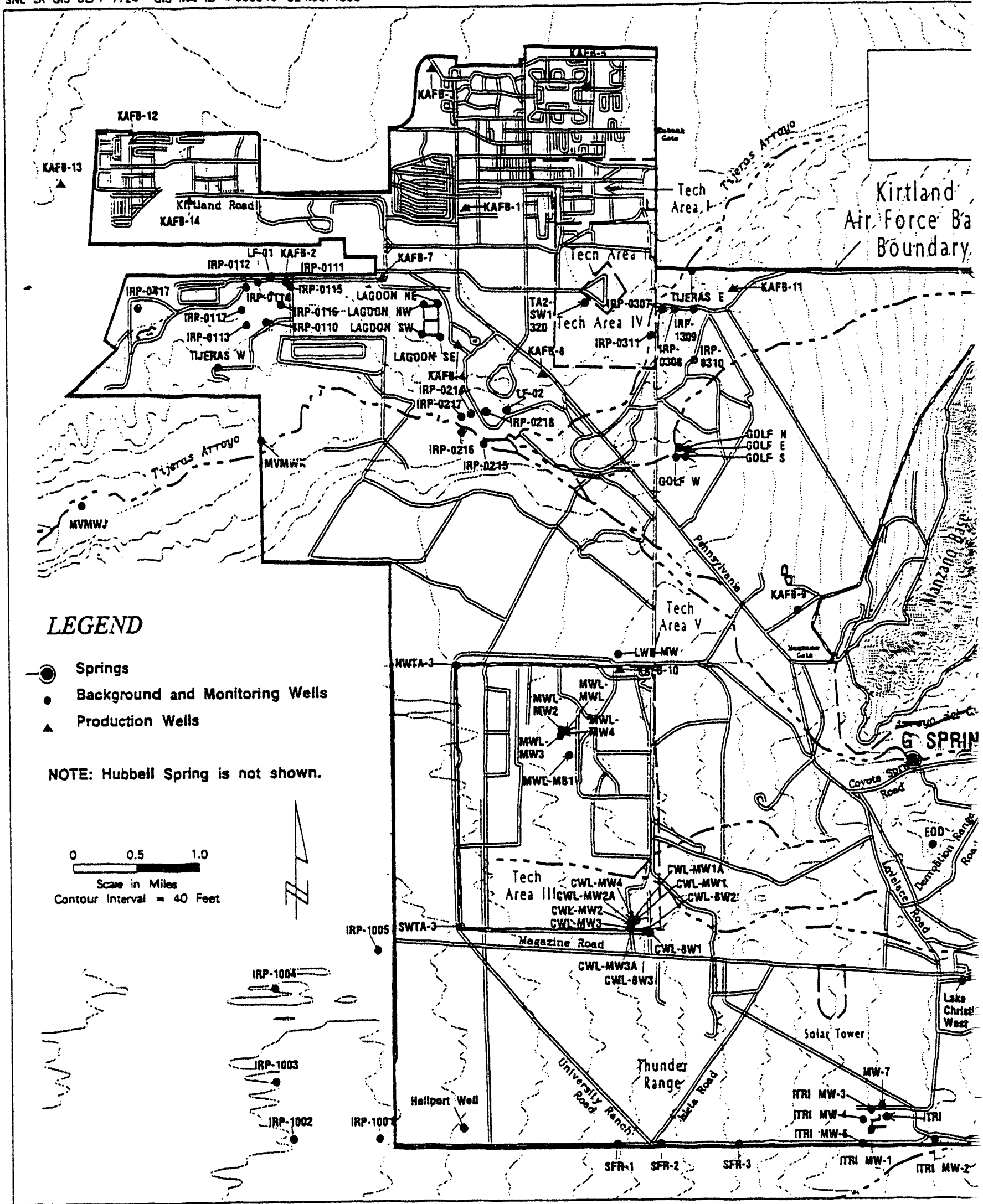

Figure 4-4. Location of $\mathbf{K}$. 


WOA
Location of KAFB Area Wells and Springs
Based on Information Available as of January 1993

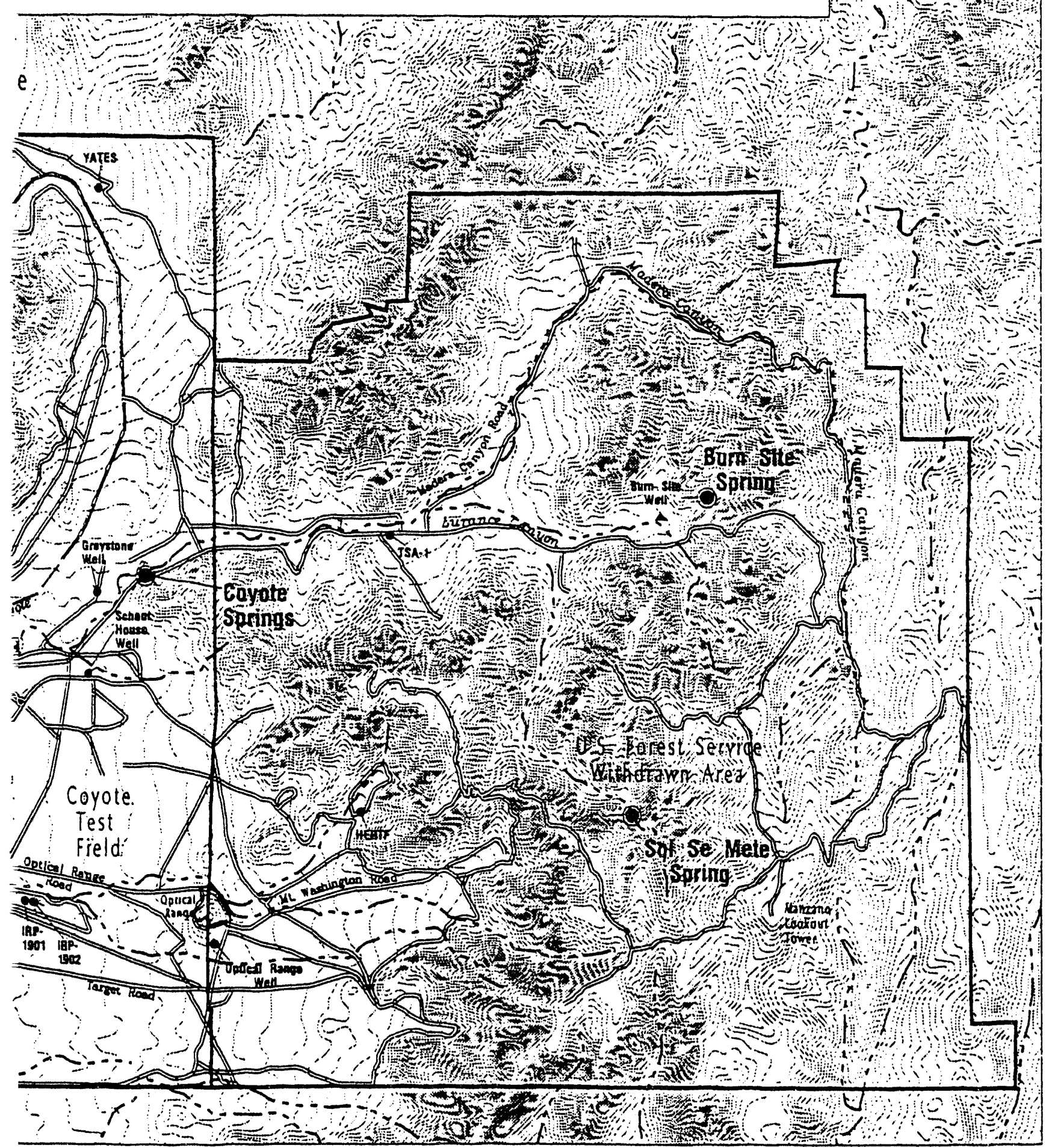

¿FB Area Wells and Springs 
Table 4-2

Stream Gauging Stations (USGS 1992)

\begin{tabular}{|c|c|c|c|}
\hline $\begin{array}{l}\text { USGS } \\
\text { STATION } \\
\text { NUMBER }\end{array}$ & STATION NAME & $\begin{array}{l}\text { DRAINAGE } \\
\text { AREA }\end{array}$ & $\begin{array}{l}\text { PERIOD OF } \\
\text { OPERATION }\end{array}$ \\
\hline 08330565 & Arroyo del Coyote near Albuquerque, NM & $\begin{array}{r}35.0 \mathrm{mi}^{2} \\
\left(90.6 \mathrm{~km}^{2}\right)\end{array}$ & $\begin{array}{l}\text { Sept. } 1989 \text { to } \\
\text { present (no winter } \\
\text { records) }\end{array}$ \\
\hline 08330567 & Arroyo del Coyote at mouth near Albuquerque, NM & $\begin{array}{l}39.0 \mathrm{mi}^{2} \\
\left(101 \mathrm{~km}^{2}\right)\end{array}$ & $\begin{array}{l}\text { Sept. } 1989 \text { to } \\
\text { present (no winter } \\
\text { records) }\end{array}$ \\
\hline 08330569 & $\begin{array}{l}\text { Tijeras Arroyo below Arroyo del Coyote near } \\
\text { Albuquerque, NM }\end{array}$ & $\begin{array}{c}126 \mathrm{mi}^{2} \\
\left(326 \mathrm{~km}^{2}\right)\end{array}$ & $\begin{array}{l}\text { July } 1989 \text { to present } \\
\text { (no winter records) }\end{array}$ \\
\hline 08330580 & Tijeras Arroyo at Montessa Park near Albuquerque, NM & $\begin{array}{l}\text { To be } \\
\text { determined }\end{array}$ & $\begin{array}{l}\text { Aug. } 1987 \text { to } \\
\text { present (no winter } \\
\text { records) }\end{array}$ \\
\hline
\end{tabular}


Table 4-3

Stream Gauging Stations for Water Years 1988 to 1991 (USGS 1992, 1993b)

\begin{tabular}{|c|c|c|c|c|c|c|}
\hline \multirow{2}{*}{$\begin{array}{c}\text { USGS } \\
\text { Station Number }\end{array}$} & $\begin{array}{c}\text { No. of } \\
\text { Days } \\
\text { with Flow }\end{array}$ & $\begin{array}{c}\text { Maximum } \\
\text { Discharge }\end{array}$ & Total Flow & $\begin{array}{c}\text { No. of } \\
\text { Days } \\
\text { with Flow }\end{array}$ & $\begin{array}{c}\text { Maximum } \\
\text { Discharge }\end{array}$ & Tocal Flow \\
\hline 08330565 & - & - & - & - & - & - \\
\hline 08330567 & - & - & - & - & - & - \\
\hline 08330569 & - & - & - & - & - & - \\
\hline 08330580 & 12 & $\begin{array}{l}2090 \mathrm{ft}^{3 / \mathrm{s}} \\
\left(59.1 \mathrm{~m}^{3 / \mathrm{s}}\right.\end{array}$ & $\begin{array}{l}350 \mathrm{acre}-\mathrm{ft}^{4} \\
\left(43.2 \times 10^{4} \mathrm{~m}^{3}\right)\end{array}$ & 4 & $\begin{array}{l}88 \mathrm{ft}^{3} / \mathrm{s} \\
\left(2.49 \mathrm{~m}^{3} / \mathrm{s}\right)\end{array}$ & $\begin{array}{l}23.7 \mathrm{acre}-\mathrm{ft} \\
\left(2.92 \times 10^{4} \mathrm{~m}^{3}\right)\end{array}$ \\
\hline
\end{tabular}

a. Water Years 1988 and 1989.

\begin{tabular}{|c|c|c|c|c|c|c|}
\hline \multirow[b]{2}{*}{$\begin{array}{c}\text { USGS } \\
\text { Station Number }\end{array}$} & \multicolumn{3}{|c|}{$1990^{\circ} /$ ATER YEAR } & \multicolumn{3}{|c|}{1991 WATER YEAR } \\
\hline & $\begin{array}{c}\text { No. of } \\
\text { Days } \\
\text { with Flow }\end{array}$ & $\begin{array}{l}\text { Maximum } \\
\text { Discharge }\end{array}$ & Total Flow & $\begin{array}{l}\text { No. of } \\
\text { Days } \\
\text { with Flow }\end{array}$ & $\begin{array}{l}\text { Maximum } \\
\text { Discharge }\end{array}$ & Total Flow \\
\hline 08330565 & 1 & $\begin{array}{l}38 \mathrm{ft}^{3} / \mathrm{s} \\
\left(1.08 \mathrm{~m}^{3} / \mathrm{s}\right)\end{array}$ & $\begin{array}{l}2.6 \text { acre-f } \\
\left(0.32 \times 10^{4} \mathrm{~m}^{3}\right)\end{array}$ & 13 & $\begin{array}{c}666 \mathrm{ft}^{3} / \mathrm{s} \\
\left(18.9 \mathrm{~m}^{3} / \mathrm{s}\right)\end{array}$ & $\begin{array}{l}150 \text { acre-ft } \\
\left(18.5 \times 10^{4} \mathrm{~m}^{3}\right)\end{array}$ \\
\hline 08330567 & 0 & 0 & 0 & 10 & $\begin{array}{c}262 \mathrm{ft}^{3} / \mathrm{s} \\
\left(7.42 \mathrm{~m}^{3} / \mathrm{s}\right)\end{array}$ & $\begin{array}{l}103 \text { acre } \cdot \mathrm{ft} \\
\left(12.7 \times 10^{4} \mathrm{~m}^{3}\right)\end{array}$ \\
\hline 08330569 & 19 & $\begin{array}{l}234 \mathrm{ft}^{3} / \mathrm{s} \\
\left(6.63 \mathrm{~m}^{3} / \mathrm{s}\right)\end{array}$ & $\begin{array}{l}68.4 \text { acre- } \mathrm{ft} \\
\left(8.44 \times 10^{4} \mathrm{~m}^{3}\right)\end{array}$ & 20 & $\begin{array}{c}787 \mathrm{ft}^{3 / \mathrm{s}} \\
\left(22.3 \mathrm{~m}^{3} / \mathrm{s}\right)\end{array}$ & $\begin{array}{l}480 \text { acre-ft } \\
\left(59.2 \times 10^{4} \mathrm{~m}^{3}\right)\end{array}$ \\
\hline 08330580 & 12 & $\begin{array}{l}65 \mathrm{ft}^{3} / \mathrm{s} \\
\left(1.84 \mathrm{~m}^{3} / \mathrm{s}\right)\end{array}$ & $\begin{array}{l}140 \text { acre-ft } \\
\left(17.3 \times 10^{4} \mathrm{~m}^{3}\right)\end{array}$ & 12 & $\begin{array}{l}1390 \mathrm{ft}^{3} / \mathrm{s} \\
\left(39.4 \mathrm{~m}^{3} / \mathrm{s}\right)\end{array}$ & $\begin{array}{l}670 \text { acre-ft } \\
\left(82.7 \times 10^{4} \mathrm{~m}^{3}\right)\end{array}$ \\
\hline
\end{tabular}

b. Water Years 1990 and 1991. 
develop channel-loss and peak attenuation equations for a module in a deterministic surface water model. The study ceased without completion in 1991 when funding was dropped.

As a part of their support for the U.S. Air Force Installation Restoration Program, the USGS collected water quality samples at four sites on the Tijeras Arroyo and Arroyo del Coyote during 1991 and 1992. These sites are shown in Figure 4-2. The results of this study indicate no contamination in the surface water, but they are preliminary and have not yet been published.

Surface water quality data at six sites in TA-I and four sites in TA-III are collected in support of a National Pollution Discharge Elimination System storm-water permit application. The results of this study have not been published.

The USGS, in cooperation with the City of Albuquerque, conducted an investigation to (1) estimate potential recharge from arroyos in the Albuquerque area and to (2) determine the quality of arroyo water that might be recharged. The scope of this study included measurement of evaporation, evapotranspiration, and infiltration in order to estimate potential recharge. One of the sites used for this study was the Tijeras Arroyo above the Four Hills Bridge [2 $\mathrm{mi}(3.2 \mathrm{~km})$ upstream of the KAFB boundary]. Gauging station 08330505 , Tijeras Arroyo above Four Hills Bridge near Albuquerque, was operated as a part of this study from May 1989 to September 1991. The water quality investigation included collection of samples that were analyzed for concentrations of major ions, nutrients, selected trace elements, and selected organic compounds.

This investigation began in 1989 and was completed in 1992; a report is in review and should be published within the next year. The preliminary results of this study show that mean daily potential for recharge was 0.61 cubic feet per second (cfs) [17 liters per second (lps)] on May 19, 1992, and that the estimated mean daily potential recharge at the Tijeras reach accounted for 95.8 percent of the loss in stream-flow volume. During the study, estimates of mean daily potential recharge ranged from 0.37 to $5.4 \mathrm{cfs}$ (10 to $153 \mathrm{lps}$ ) (USGS 1993a).

\subsubsection{Additional Data or Studies Needed}

All watersheds and subwatersheds need to be delineated and entered into the Geographic Information System. The flood hazards study done by the COE in 1979 should be reviewed and revised if necessary. The additional stream gauge data collected since the late 1970s might be sufficient to revise the flood frequency discharges. If the flood frequency discharges are revised, the flood routing analysis will need to be redone. An additional flood hazards study should be done for the watershed that lies south of the Arroyo del Coyote watershed. There are about forty ER sites in, or in the downstream area of, this basin.

Additional gauging stations need to be placed at strategic locations in the upper basin of Arroyo del Coyote, and at least one station should be located in the unnamed basin south of Arroyo del Coyote. The hydrology of the Arroyo del Coyote Basin is significant because there are approximately $25 \mathrm{ER}$ sites in that basin. The data from these gauges will be used to characterize the hydrology of these basins, and will be used in combination with existing 
stream-flow data to calibrate a surface water model and to help define boundary conditions for the groundwater models.

A deterministic surface water model should be developed for the Arroyo del Coyote Basin and for the unnamed basin south of Arroyo del Coyote. This model will give us a better understanding of the surface water processes and will allow us to better predict flooding and recharge to the groundwater.

Surface water pathways need to be developed for each of the ER sites. A surface water pathway will show the path that surface water would take to get to the site and the path and ultimate destination of water running away from the site. The size of the area contributing water to the site would also be identified. This activity would be undertaken in coordination with ER site-specific RFI work.

\subsection{Vadose Zone Hydrology}

The vadose (or unsaturated) zone is the region located between the land surface and the groundwater system (the saturated zone). The water table, defined as the surface on which the fluid pressure in the pores is exactly atmospheric, is commonly thought to be the boundary between the vadose zone and saturated zone (Freeze and Cherry 1979). The vadose zone provides the link between surface water hydrology (which deals with surficial processes such as precipitation, snow melt, run-off, infiltration, overland flow, and evapotranspiration) and groundwater hydrology, which is concerned with the flow and transport processes in aquifer systems (Gee and Hillel 1988).

The vadose zone is an important part of the hydrologic system in the SNL/KAFB area. In this semiarid climate, the vadose zone thickness is generally quite large [from 50 to greater than $500 \mathrm{ft}$ ( 15 to greater than 152 meters)]; consequently, most contaminants released near the ground surface must travel a long distance before reaching the groundwater system. The majority of the ER sites are located at or near the land surface. Approximately half of these sites are located east of the Tijeras/Hubbell Spring/Sandia Fault complex, where the depth to groundwater is shallower than the deep groundwater west of the faults (see Section 4.3.1). Contaminant concentrations that reach the water tabie are a concern with respect to the RCRA maximum contaminant limit (MCL). Dispersive effects in the vadose zone could dilute contaminant concentrations to the point that when and if contaminants reach the water table, concentrations might be less than the MCL, thereby causing no risk to human health or the groundwater resource through the groundwater system. The regional areal recharge rate, which controls the upper boundary condition of the saturated zone, is also affected by vadose zone characteristics.

However, where the water table is deep and the layers above it are very heterogeneous, flow through the vadose zone can be very difficult to define (Gee and Hillel 1988). Part of the difficulties arise due to technological limitations in measuring vadose zone properties. The physical measurements currently in use to determine flow- and transport-related properties of unsaturated porous media and their limitations are discussed by Dane and Moltz (1991), Everett et al. (1984), and Wilson (1983). Another problem is our incomplete understanding of vadose zone flow and transport processes, especially in areas with thick vadose zones. 
The influence of hydraulic property variability on unsaturated flow and transport, multiphase flow and transport, preferential flow and transport due to macropore flow (e.g., large pores from cracks and root channels) and unstable flow (i.e., fingering), advective and diffusive flow of soil gas, and prediction of groundwater recharge in arid and semiarid climates are areas of current vadose zone research described by Gee et al. (1991) that might provide methods for solving vadose zone problems in the SNL/KAFB area.

\subsubsection{Vadose Zone Hydrogeologic Framework}

Important flow and transport processes in the vadose zone are highly interconnected with and dependent upon many other facets of the hydrogeologic picture, such as climate, geomorphology, vegetation, geology, and the location of the saturated zone. In general, in the SNL/KAFB area water enters the hydrologic system from rainfall and channel losses from flow in arroyos and leaves the system as evapotranspiration to the atmosphere and recharge into the underlying aquifer. The following discussion briefly describes the interrelated hydrogeologic features important to the vadose zone in terms of their effect on our current $\mathrm{CM}$ for flow and transport through the vadose zone in the SNL/KAFB area.

The SNL/KAFB area has a semiarid climate, characterized by low precipitation; wide temperature extremes; frequent drying winds; some heavy rain showers, usually of short duration, often with erosive effects; and an erratic, seasonal distribution of precipitation (Section 4.1.1). The average precipitation typically increases with elevation; thus, the distribution of precipitation varies in an increasing fashion from the western to the eastern portion of the area (Figure 4-1). This climate implies low recharge rates to the groundwater system from areal infiltration due to the low precipitation and high evapotranspiration conditions. Whether any areal infiltration (and consequent downward transport of contaminants to the water table) occurs through the geologic media between major arroyos is presently unknown. Recharge studies conducted on open rangeland at the Sevilleta National Wildlife Refuge south of Albuquerque indicate modern deep drainage rates ranging from millimeters to a couple of centimeters per year (Stephens and Knowlton 1986, McCord and Stephens 1987. Phillips et al. 1988), and recent observations at the Walnut Gulch Experimental Watershed in southeast Arizona showed significant moisture pulses moving below the presumed root zone (Goodrich 1992). However, recent environmental isotope studies in the nearby Santa Fe Basin suggest "negligible" recharge (Anderholm 1992). If there is any (even small) interchannel areal recharge, when integrated over a large area such recharge can contribute a significant volume of water to the site-wide water balance.

There are no continuously running streams in the SNL/KAFB area, although there is a system of arroyos that flow ephemerally, primarily during or after large thunderstorm events. In this vicinity, Tijeras Arroyo and Arroyo del Coyote are probably the largest localized recharge source (Anderholm 1992). The magnitude of arroyo flow loss due to evapotranspiration and infiltration into the vadose zone (causing possible recharge to the groundwater system) is unknown.

The major vegetation types in the SNL/KAFB area also tend to vary with elevation, slope, and aspect. Generally, woodlands are found in the eastern portion of the area in the Manzanita Mountains and canyons, whereas grasslands cover the western portion of the area 
on the lower elevations (IT and Consensus Planning, Inc. 1992) (Figure 3-7). The landsurface percent slope in the SNL/KAFB area varies from less than 1 percent to greater than 46 percent (Figure 4-5). Most mountain ridges trend to the northwest-southeast; therefore, many of the steep slopes face either southeast or northwest (Figure 4-6). Vegetation characteristics and slope affect the surface run-off and potential infiltration rates. Steep slopes facing the southeast receive more sunshine for longer periods of time than those facing northwest, possibly causing different evapotranspiration rates to occur on southeast-versus northwest-facing slopes. Currently, surface run-off characteristics and evapotranspiration rates in the area are not well understood.

Soils in the SNL/KAFB area are dominated by well-drained, loamy soils, with gravelly and stony soils along the arroyos and on the mountains (USDA Soil Conservation Service, 1977) (Figure 3-6) (see Section 3.3.1). The USDA Soil Conservation Service (1977) has designated the permeabilities (Figure 4-7) and available water capacities (Figure 4-8) of the soils in the area, based on the mapped soil textures. Permeabilities are mainly moderately slow to moderately rapid $[0.2$ to $6 \mathrm{in} . / \mathrm{hr}(.5$ to $15.2 \mathrm{~cm} / \mathrm{hr})]$ in the area, whereas the canyon bottoms and the Tijeras Arroyo flood plains exhibit rapid [6 to $20 \mathrm{in.} / \mathrm{hr}$ (15.2 to $50.8 \mathrm{~cm} / \mathrm{hr}$ )] permeabilities. Available water capacity is inversely correlated with the permeabilities (i.e., high water capacity corresponds with low permeability, as in a clayey soil). Infiltration is more likely to occur in areas with high permeabilities than areas with low permeabilities, where there is greater surface run-off potential. Note that regions where no permeability data exist (Figure 4-7) are classified as rock outcrop (Figure 3-6), which might have very low matrix permeabilities. If the rock outcrops are fractured, the fractureflow permeabilities might be very high, creating zones at high elevations (which correspond with the highest annual precipitation) at which large infiltration into the system could occur. The actual surface and subsurface conditions of the rock outcrop areas are unknown.

The vadose zone generally consists of unconsolidated valley-fill deposits. The valley fill consists of unconsolidated and semiconsolidated sands, gravels, silts, and clays of the Santa Fe Group (see Section 3.1.2). On the west side of the SNL/KAFB area, the valley fill is composed of highly heterogeneous alluvial fan, fluvial, and aeolian deposits. Farther west of SNL/NM facilities, the distal alluvial fan materials interfinger with generally finer Rio Grande sediments. In the eastern portion of the SNL/KAFB area, there might be areas where the vadose zone is composed of bedrock materials (e.g., Precambrian, Pennsylvanian, or Permian Formations) of relatively low permeability, but that might be highly fractured (see Section 3.1.1).

As previously discussed, the vadose zone thickness in this area is generally quite large. The depth to groundwater, and hence vadose zone thickness, appears to be strongly controlled by the Sandia Fault, Hubbell Spring Fault, and Tijeras Fault systems (Figure 4-9). In areas west of the faults, the vadose zone is typically on the order of 300 to $500 \mathrm{ft}$ ( 91 to $152 \mathrm{~m}$ ) thick, whereas east of the faults, the vadose zone thickness ranges from about 50 to $140 \mathrm{ft}$ (15 to $43 \mathrm{~m}$ ) according to water levels recorded in monitor wells (SNL/NM 1993). Note that east of the fault zone there are significant areas where bedrock is outcropping and where seeps and springs indicate much smaller depths to groundwater (see Figure 4-4). 


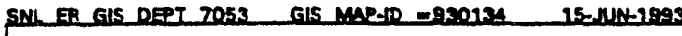

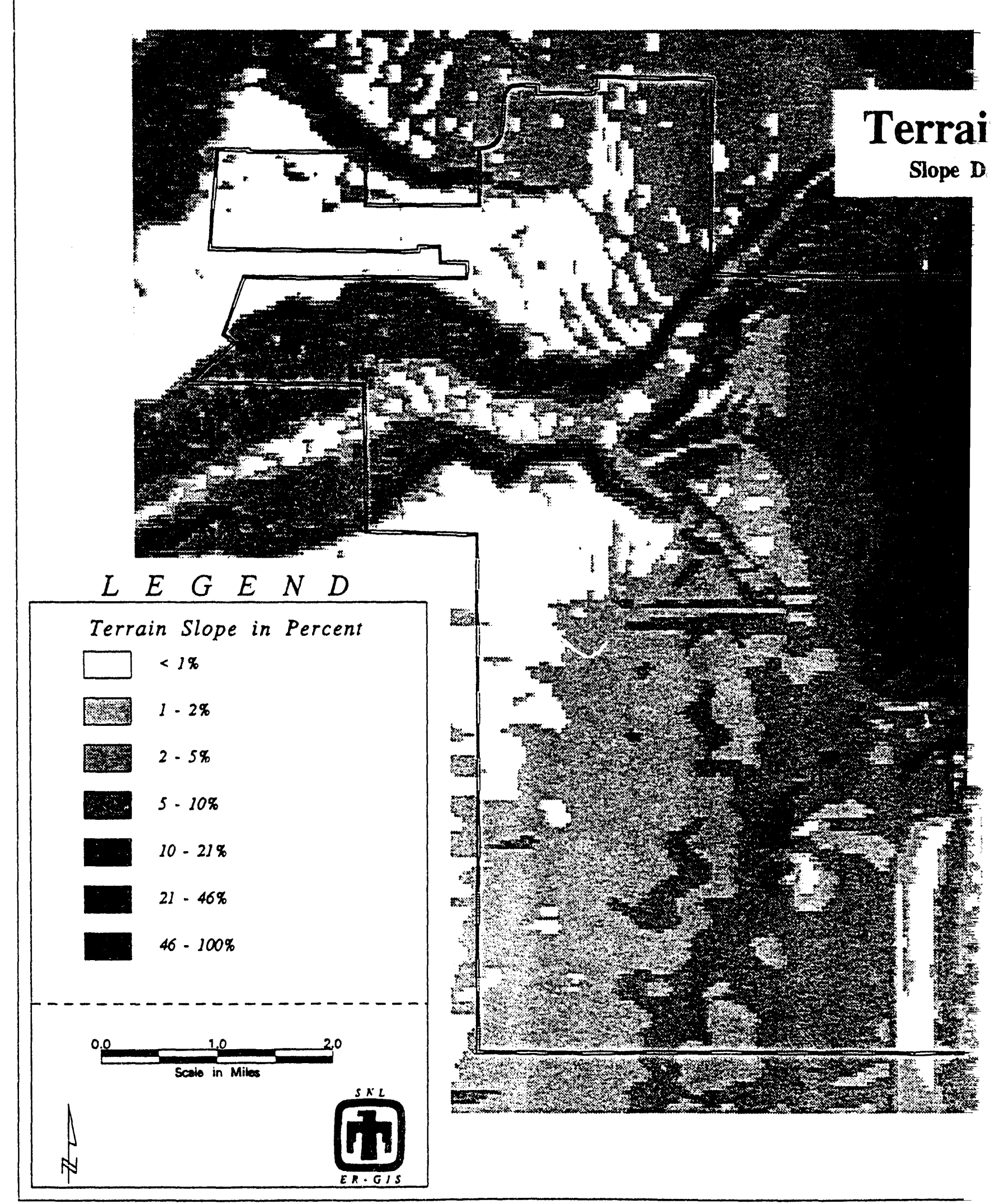

DIGTTAL MAP PREPARED BY: M. I FURAUS

Figure 4-5. Surface Slc 


\section{Slope in the SNL/KAFB Area}

ta Derived from USGS 30×30 Meter Digital Elevation Models

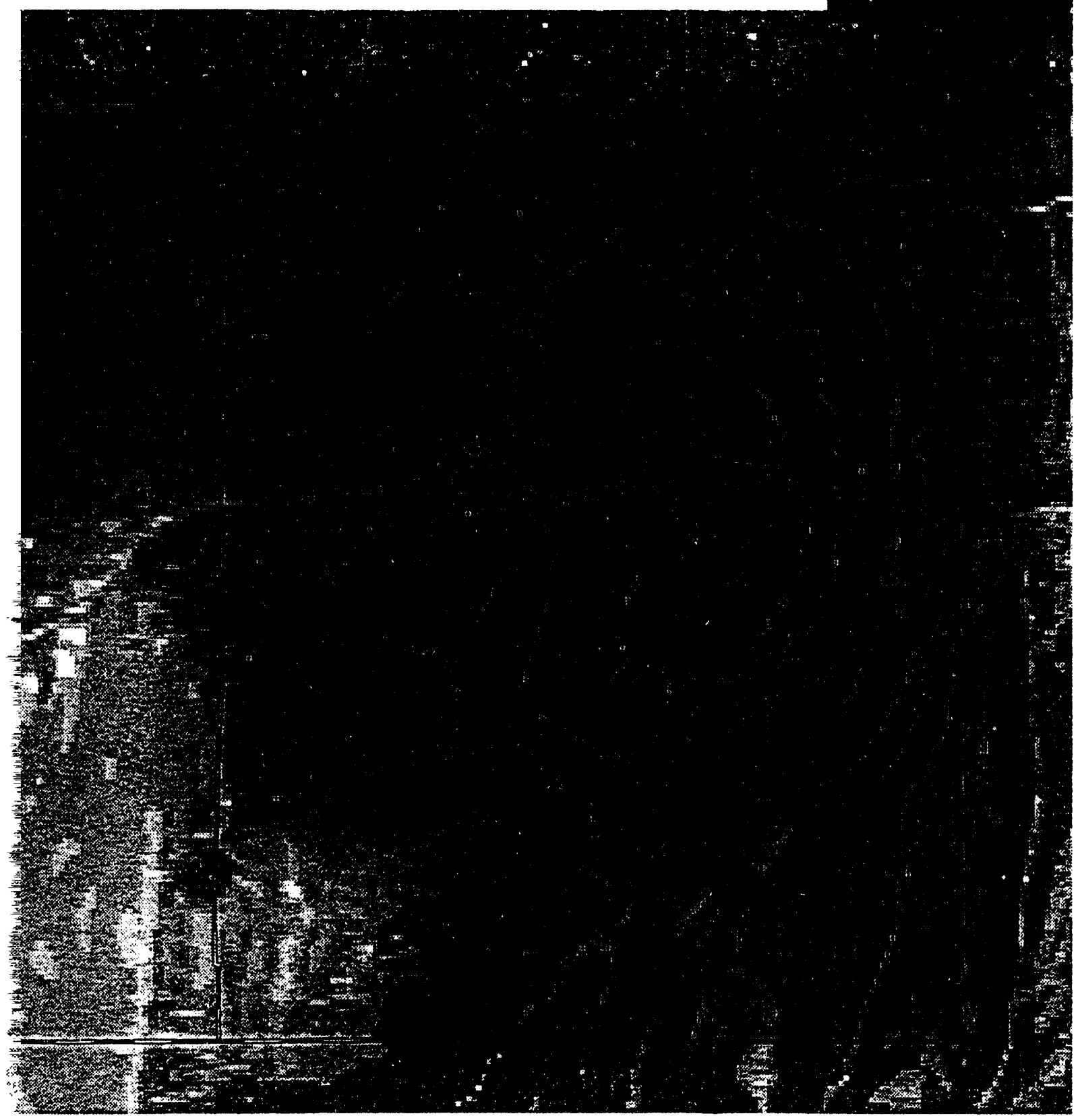

\& of Terrain in the SNL/KAFB Area 


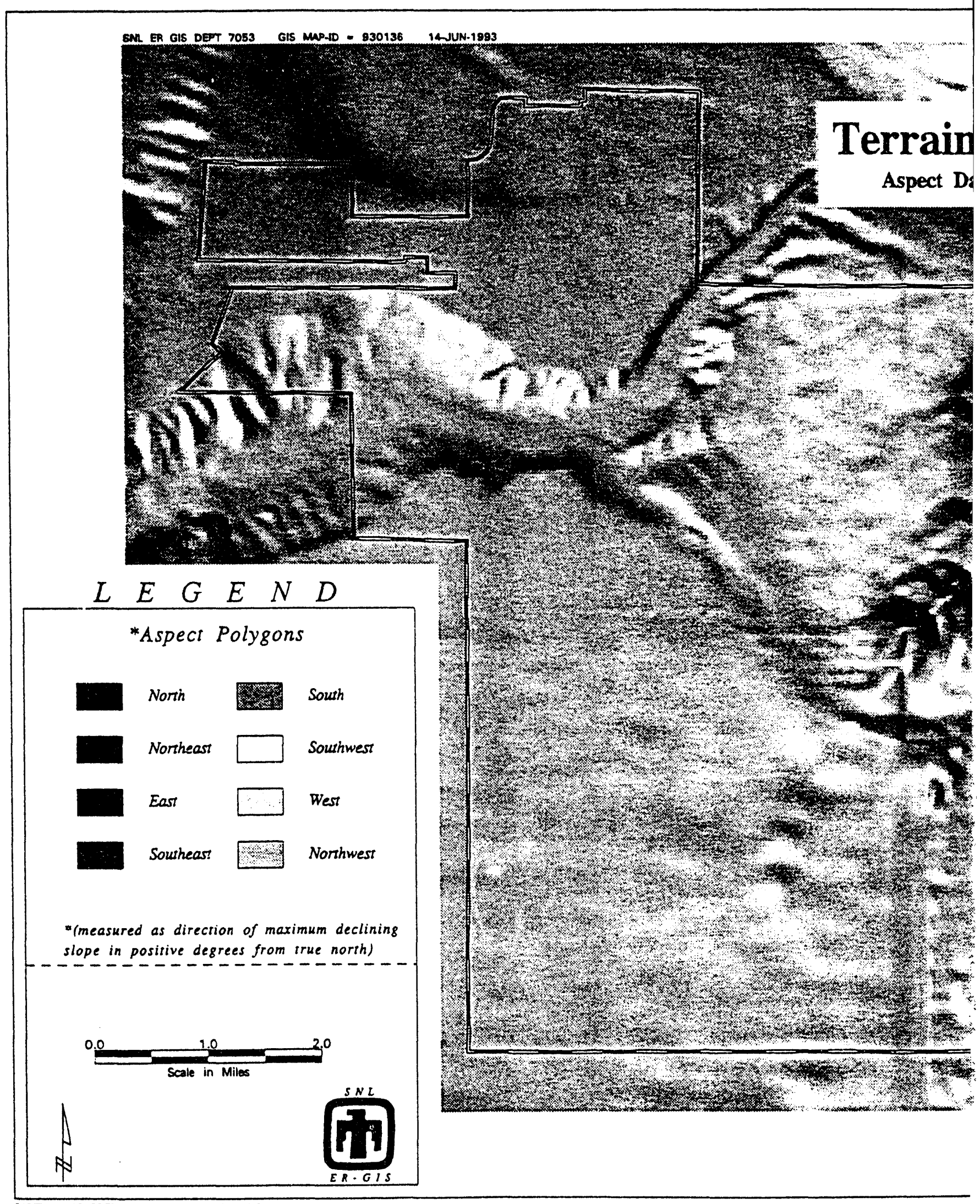

DIGTTN MAP PREPARED BY: M. \& FURAUS

Figure 4-6. Surface Aspect of ' 


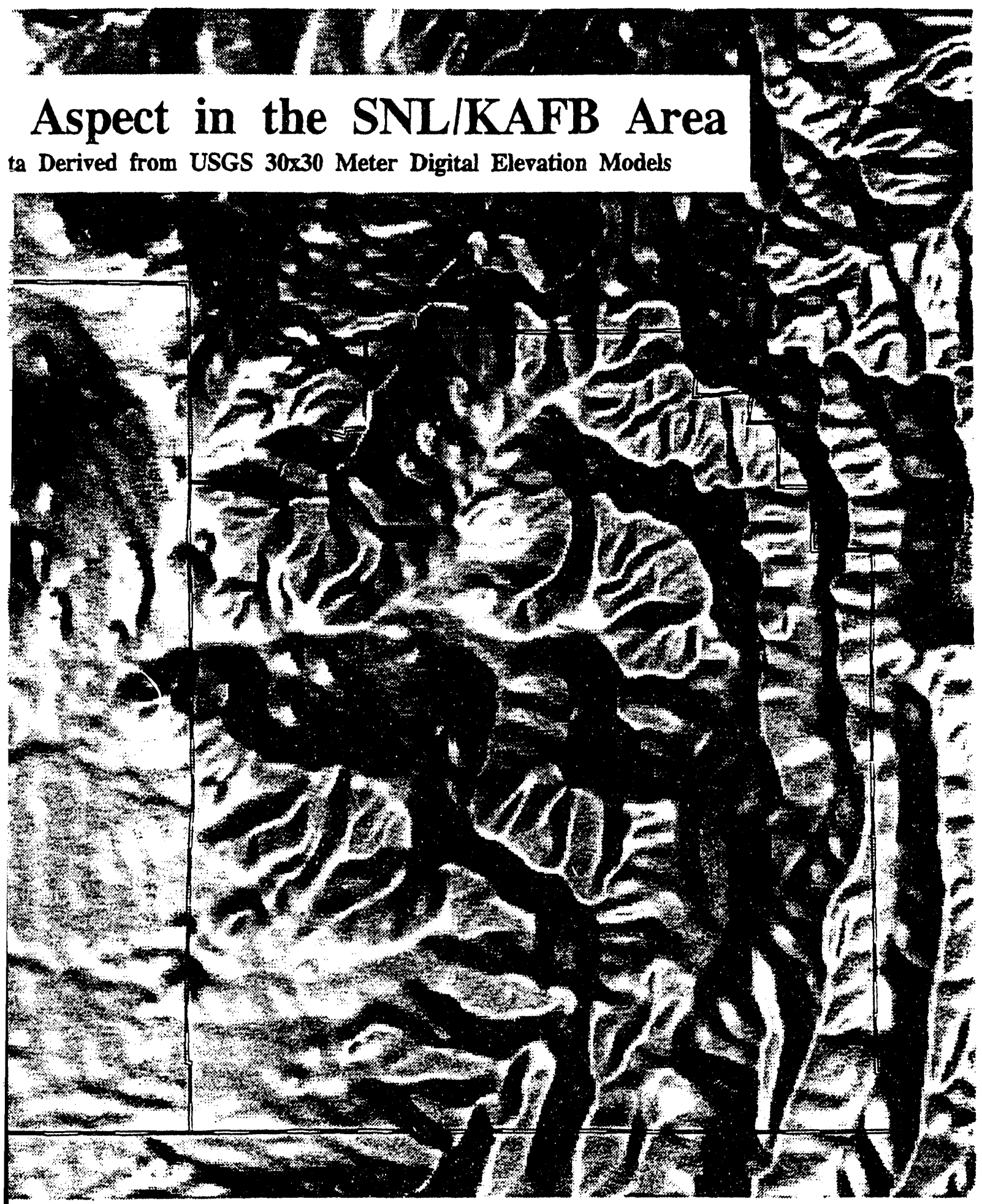




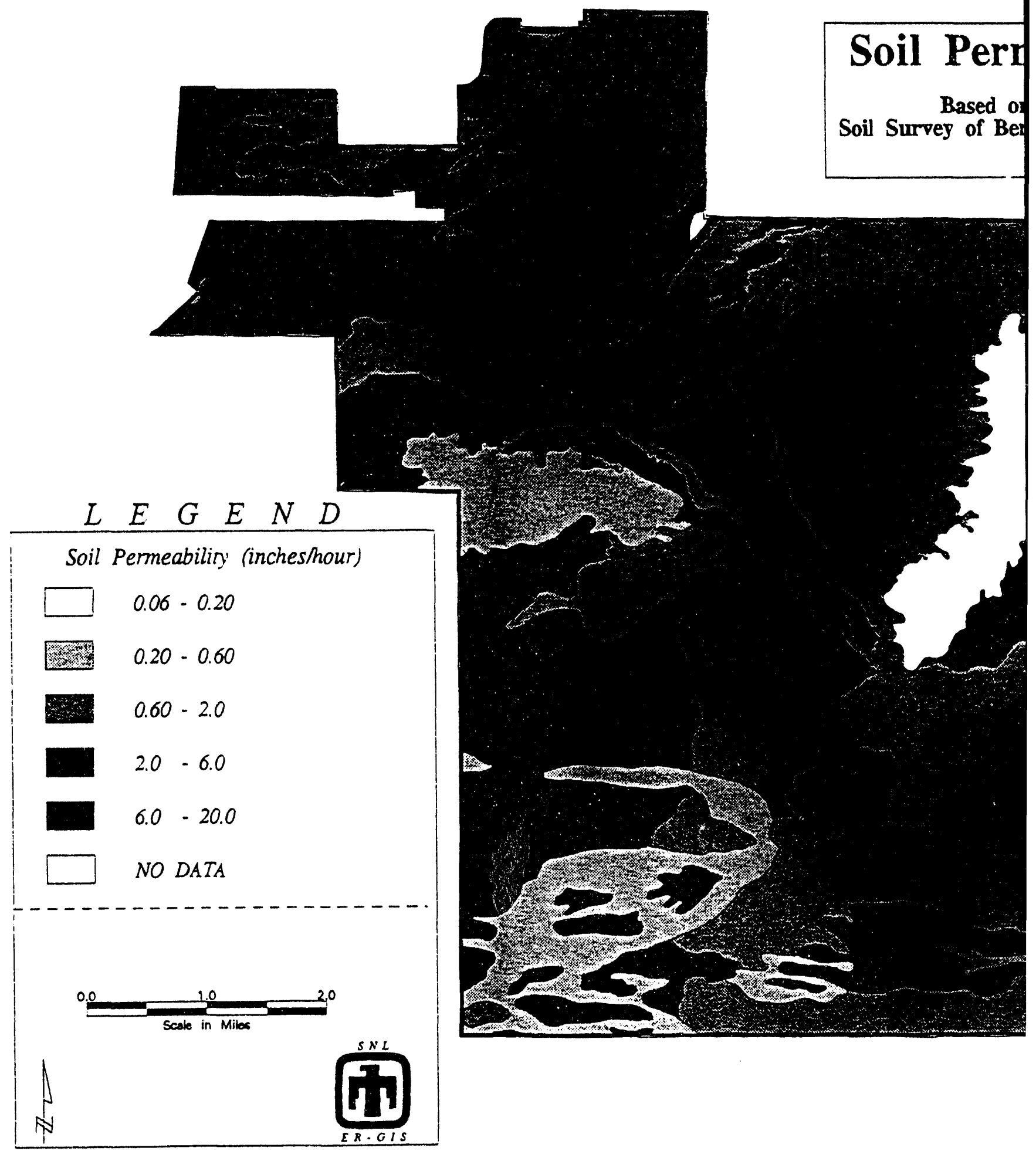




\section{reability in the SNL/KAFB Area}

Data from U.S.D.A., Soil Conservation Service Report:

nalillo County and Parts of Sandoval and Valencia Counties, NM June, 1977

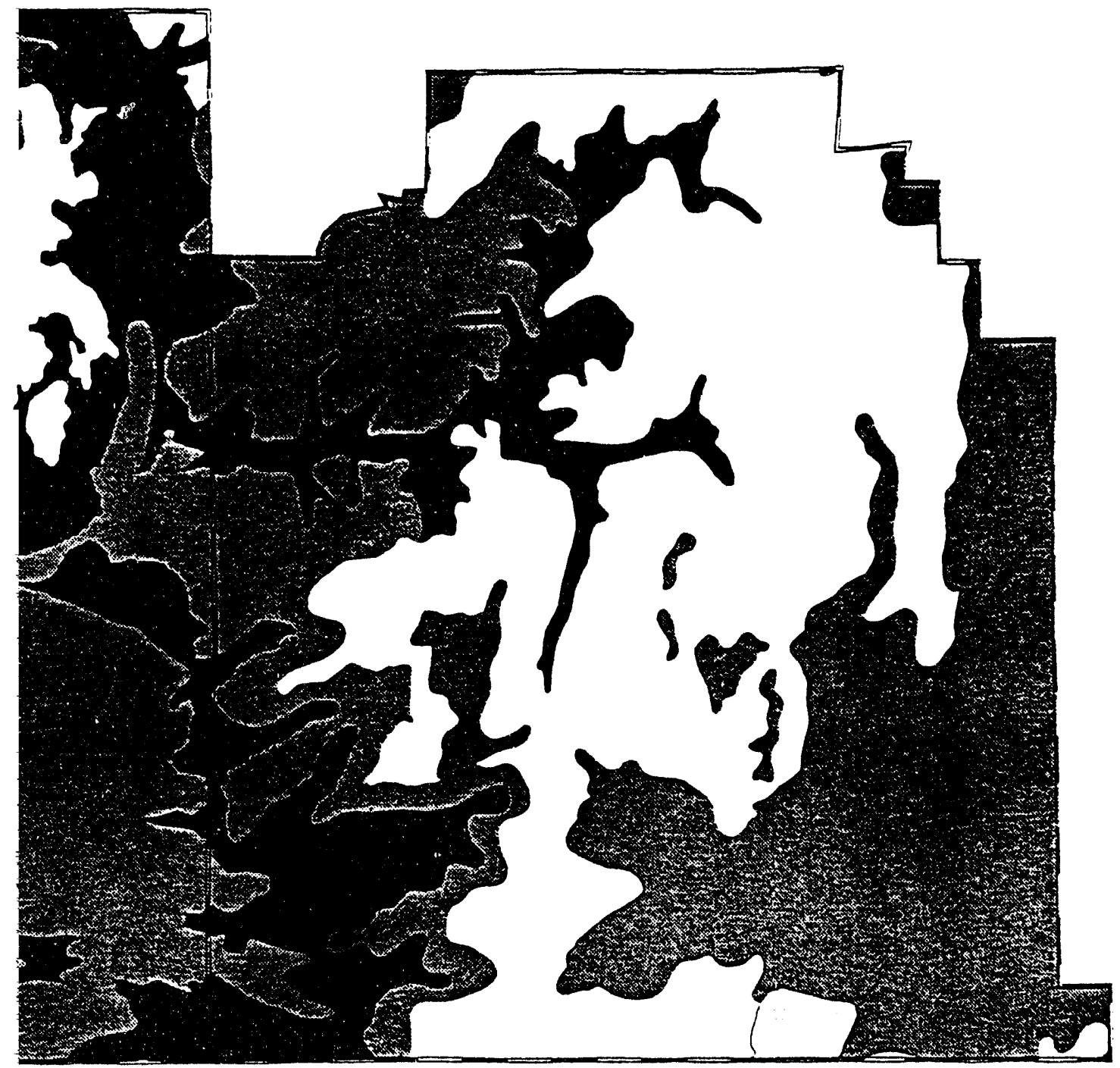

Is in the SNL/KAFB Area 


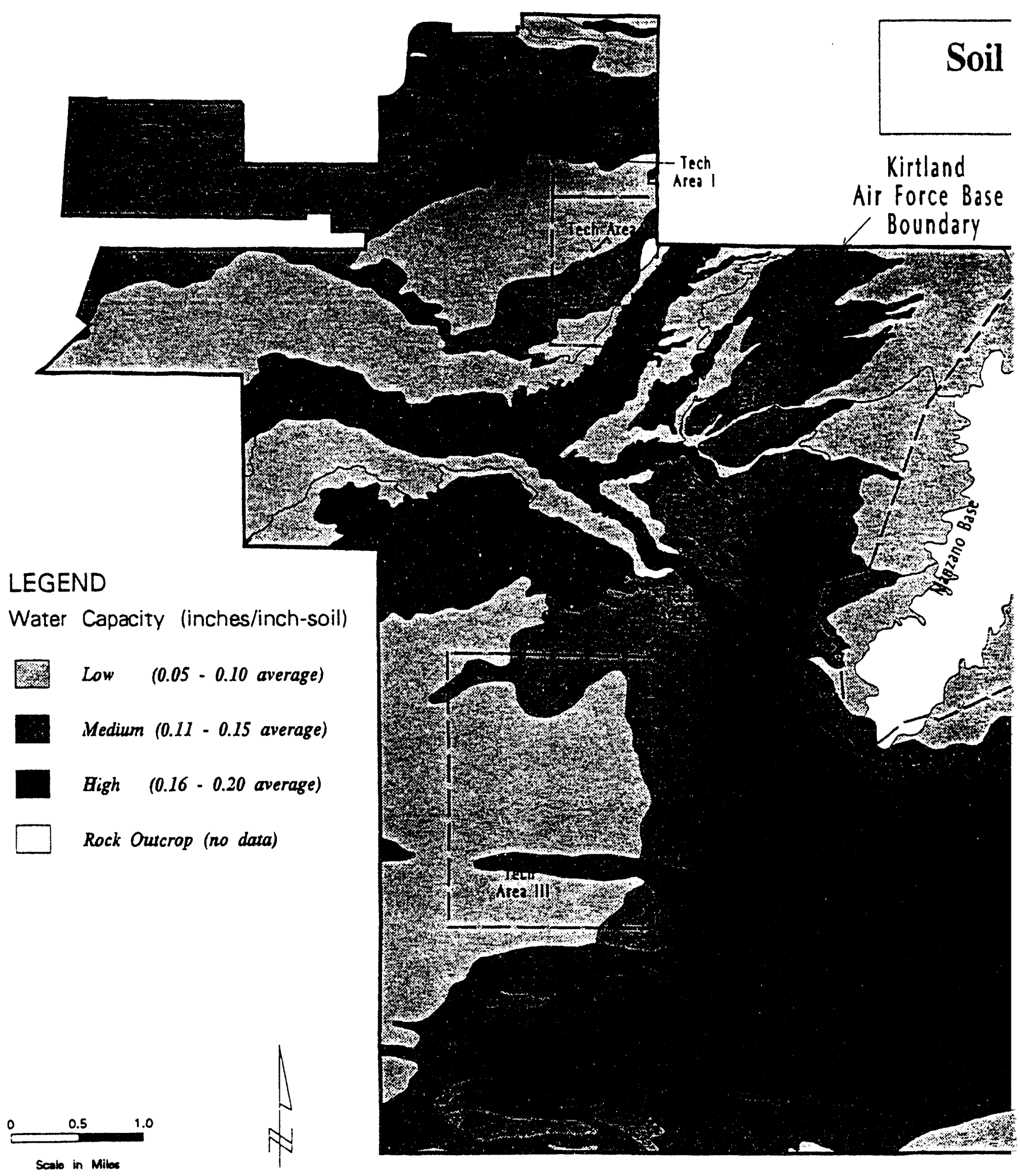

Figure 4-8. Soil Water Capar 


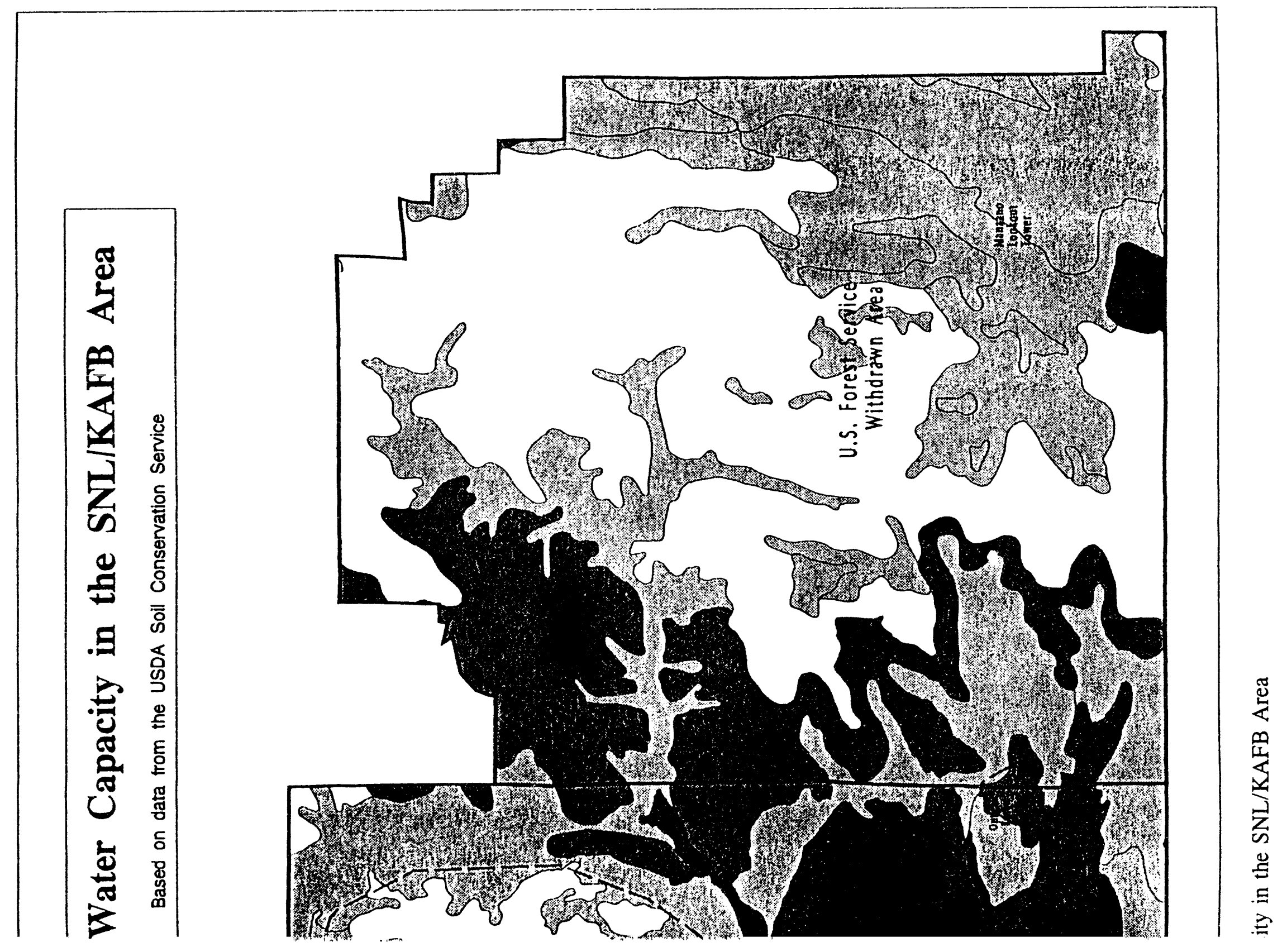




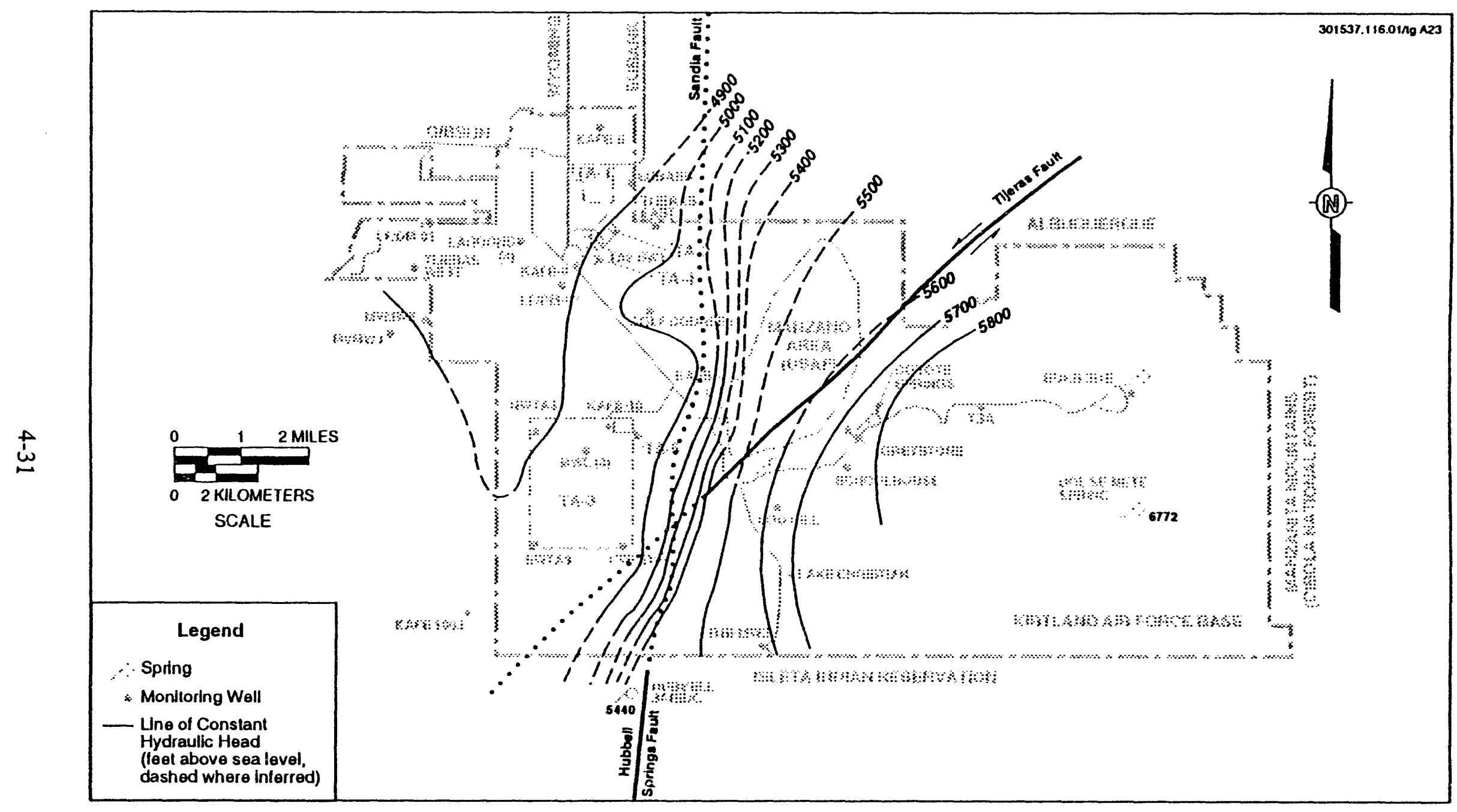

Figure 4-9. Potentiometric Surface of the SNL/KAFB Area Based on July 1992 Monitoring-Well Water Level Measurements from the Data Points Shown (Locations of major faults are indicated) 
The precise mode(s) of deep water flow in semiarid alluvial sediments is also poorly understood. In the vadose zone, fine-grained material (small pores) might act as the preferred pachway for moisture movement, whereas coarse-grained material (larger pores) can act as a barrier to flow. Therefore, an understanding of the thickness, lateral extent, and bedding angles of various geologic units is essential for developing CMs for contaminant movement through the vadose zone. Layers and lenses could cause preferential flow to occur, and enhance dispersion processes. The presence of paleochannels could also impact flow paths through the vadose zone. It is generally assumed that the horizontal layering of the geologic media in the vadose zone would cause spatially variable natural surface fluxes to be smoothed into a fairly uniform downward drainage below a few meters of depth.

However, for large fluid sources (such as intensively used septic tank leach fields) it is likely that bulbs of high saturation would develop beneath these sources. Furthermore, there is the possibility that even natural, nonuniform surface wetting might act synergistically with the media's unsaturated hydraulic characteristics (e.g., unsaturated conductivity/moisture-content relationships and water-entry and air-entry pressures) to permit nonuniform flow to propagate to great depths, perhaps even resulting in unsaturated "finger flow" or channeling to the water table [see studies by Glass et al. (1988), Kung and Samuel (1988), and Cislerova et al. (1990)]. If nonuniform water flows do occur to great depth, this might greatly reduce the expected time of contaminant transport from the ground surface to the groundwater system.

\subsubsection{Flow and Transport Processes and Parameters}

Vadose zone studies conducted by the SWHC project will be consistent with the quantitative approach described in Section 2.0, which includes developing a high-level problem definition and then taking a risk-based, quantitative approach toward prioritization of data collection (i.e., characterization) activities (see Section 2.4). Characterization activities include measuring parameters in the field or laboratory that allow us to understand the importance of a specified parameter and to refine CMs of the hydrogeologic system (see Section 2.3). Perhaps most importantly, characterization facilitates the quantitative prediction of site performance (e.g., how contaminants can be transported from sources to receptors).

One of the first steps in the problem-definition process (Section 2.1) involves identifying all possible processes of concern. Liquid-phase processes (e.g., miscible and immiscible displacement, sorption, diffusion/dispersion, and biogeochemical decay), gas-phase processes (e.g., diffusion/dispersion, and barometric pumping), and convergence/divergence processes (e.g., capillary barriers, density driven flow, and topographical control) are some of the vadose zone flow and transport processes that have been identified as possibly being important in the SNL/KAFB area. Parameters that describe important flow and transport processes in the vadose zone need to be described. For example, directly measuring the unsaturated hydraulic conductivity parameter by performing an infiltration test would provide information about the liquid-phase movement process. 


\subsubsection{Previous Studies}

Only one study has been conducted in the SNL/KAFB area to exclusively characterize vadose zone flow and transport parameters (Persaud and Wierenga 1982). However, some data were collected during site investigation work at SNL/NM's CWL and MWL that are also useful in developing a $\mathrm{CM}(\mathrm{s})$ of the vadose zone hydrogeologic system. The vadose zone is very thick at these sites, on the order of $500 \mathrm{ft}(152 \mathrm{~m})$. Investigations conducted prior to calendar year 1992 are discussed in this section.

\section{Persaud and Wierenga (1982)}

A contaminant migration study was conducted in 1978 by New Mexico State University (Persaud and Wierenga 1982). They performed batch adsorption experiments for seven inorganic compounds and chromium transport column tests using both disturbed and undisturbed core samples collected from the CWL and MWL areas. The inorganics studied included cesium, strontium, chromium, lead, mercury, nickel, and cadmium. In general, the equilibrium adsorption data showed that all of the metals were strongly adsorbed to the sediments from both sites, with the exception of chromium as $\mathrm{CrO}_{4}{ }^{=}$. Thus, based on mobility of contaminants dissolved in water, chromium was the only inorganic compound of concern studied by Persaud and Wierenga (1982).

\section{$\underline{C W L}$}

Several investigations at the CWL provide insight to the vadose zone characteristics in the TA-III vicinity. A more detailed summary of past studies can be found in the CWL Closure Plan (SNL/NM 1992a).

The first contaminant migration investigation at the CWL was conducted in 1971 to determine whether hazardous wastes were migrating from disposal trenches to the vadose zone. Five boreholes were drilled in and around the landfill to a depth of $50 \mathrm{ft}(15 \mathrm{~m})$. Fifteen soil samples (three from each borehole) were analyzed for seven organics and inorganics (Phelan 1989). The analytical results indicated that no contaminants were present (Weston 1984).

Several sets of wells have been installed at the CWL to establish a monitor-well network to satisfy RCRA regulatory requirements. While drilling a total of nine wells in 1985 and 1988, lithologic logs and borehole geophysical logs were obtained, as well as sediment samples for contaminant analysis (IT 1985, DOE 1988). In 1990, fairly continuous core was obtained to about $275 \mathrm{ft}(84 \mathrm{~m})$ below land surface during the installation of monitor well MW-4 (SNL/E\&E 1990). Thirty sediment samples from MW-4 core were analyzed for unsaturated hydraulic properties, including saturated and unsaturated hydraulic conductivity, moisture characteristic relationships, initial moisture, bulk density, porosity, and particle size distribution (Stephens \& Associates 1990a, 1990b). Results of the core unsaturated hydraulic property tests are summarized in Table 4-4.

Six sediment borings were drilled in 1989 north of the CWL to investigate correlation lengths of the geologic units as part of the Hazardous Waste and Remedial Action Program Landfill 
Table 4-4

Core Unsaturated Hydraulic Property Tests

\begin{tabular}{||l|c|c|c|c|c|c|c|c|}
\hline \hline INVESTIGATION & LOCATION & GRAIN SIZE & $\theta_{i}$ & $\mathrm{P}_{\mathrm{b}}$ & $\mathrm{K}_{\text {sat }}$ & $\theta$-psi & $\mathrm{K}_{\text {unsat }}$ & TOC \\
\hline $\begin{array}{l}\text { Persaud and } \\
\text { Wierenga (1982) }\end{array}$ & CWL/MWL & 44 & 37 & 14 & & & & 3 \\
\hline $\begin{array}{l}\text { Thomson and Smith } \\
(1985)\end{array}$ & CWL & & 64 & & & & & \\
\hline $\begin{array}{l}\text { IT Corporation } \\
(1985)\end{array}$ & CWL & & & & & & & 61 \\
\hline $\begin{array}{l}\text { McTigue and Stein } \\
(1990)\end{array}$ & CWL & & 20 & & 20 & 20 & 20 & \\
\hline DBS\&A (1990a,b) & CWL & 30 & 30 & & 30 & 30 & 30 & \\
\hline $\begin{array}{l}\text { IT Corporation } \\
(1992)\end{array}$ & Sanitary & 66 & & & & & & \\
\hline \hline Total & & 140 & 151 & 14 & 50 & 50 & 50 & 64 \\
\hline \hline Range (Low) & & $*$ & $0.49 \%$ & 1.60 & $4 \times 10^{-6}$ & $*$ & $*$ & 100 \\
\hline Range (High) & & $*$ & $13.1 \%$ & 2.12 & $4 \times 10^{-3}$ & $*$ & $*$ & 2200 \\
\hline
\end{tabular}

Numbers $=$ number of samples analyzed

CWL = Chemical Waste Landfil

MWL = Mixed Waste Landfill

$\theta_{i}=$ initial moisture $(\mathrm{gm} / \mathrm{gm})$

$\vec{P}_{b}=$ bulk density $\left(\mathrm{gm} / \mathrm{cm}^{3}\right)$

$\mathrm{K}_{\mathrm{sat}}=$ saturated hydraulic conductivity $(\mathrm{cm} / \mathrm{sec})$

$\theta$-psi $=$ moisure characteristics relationship

$\mathbf{K}_{\text {unsat }}=$ unsaturated hydraulic conductivity

$\begin{aligned} \text { TOC } & =\text { total organic carbon }(\mathrm{mg} / \mathrm{kg}) \\ & =\text { unable to list meaningful range values }\end{aligned}$ 
Cap Verification Project (McTigue and Stein 1990). Twenty soil samples were analyzed for saturated hydraulic conductivity, initial moisture content, and moisture characteristic relationships. McTigue and Stein (1990) concluded that no lateral correlation exists between stratigraphic units over tens of meters.

A series of boreholes were drilled in 1981, 1983, and 1987 to study chromium migration from some of the CWL disposal pits (Thomson and Smith 1985, Stein and McTigue 1989). Analytical data results suggest that chromium has migrated with the water phase through the vadose zone. By 1987, the chromium plume was found to a depth of $75 \mathrm{ft}(23 \mathrm{~m})$. Lateral spreading from the edge of the pit was estimated to be about $20 \mathrm{ft}(6 \mathrm{~m})$ (Stein and McTigue 1989).

Prior to 1990 , no groundwater contamination had been detected at the CWL. However, trichloroethylene, a dense nonaqueous-phase liquid (DNAPL), was detected in the dissolved phase at low levels in the groundwater sampled from monitor well MW-2A in March of 1990 (SNL/NM 1991a). Corrective action activities for characterizing and remediating the trichloroethylene have begun (SNL/NM 1992a). Our current CM suggests DNAPL movement to shallow depths beneath the CWL, then vapor-phase transport through the vadose zone with subsequent partitioning of the contaminant from the vapor phase to the groundwater (Conrad et al. 1992).

\section{$\underline{M W L}$}

Data collected at the MWL provide further insight about the vadose zone characteristics in TA-III. A monitor-well network consisting of four wells was installed at the MWL during two phases of drilling conducted in 1988 and 1989 (DOE 1988, E\&E 1990). Lithologic data and borehole geophysical logs were collected during these drilling activities. To date, no groundwater contamination has been detected at this site (SNL/NM 1993).

Preliminary work to characterize the site lithology and identify locations and concentrations of contaminant releases from the MWL was performed in 1989 (E\&E 1990). Fifteen borings were drilled immediately adjacent to and angled beneath the landfill. Lithologic cross sections based on the soil-boring geologic data were developed. Some fairly extensive gravel deposits were identified at depths ranging from approximately $50 \mathrm{ft}(15 \mathrm{~m})$ and 95 to $130 \mathrm{ft}$ ( 29 to $40 \mathrm{~m}$ ) below ground surface. Tritium contamination was found to depths of approximately $65 \mathrm{ft}(20 \mathrm{~m})$ below the land surface (E\&E 1990).

\section{Sanitary Sewer Line Trench}

As discussed in Section 3.1.4, geologic data were collected in 1991 during the installation of a sanitary sewer line that went from the north end of TA-III to the ITRI. Grain size distribution analyses of some grab samples collected from the trench face provide some information about the ranges in hydraulic flow properties at shallow depths (McCord et al. 1993). 


\section{Summary}

Vadose zone hydraulic characterization data collected during ER site investigation studies conducted prior to calendar year 1992 are summarized in Table 4-4. In general, the large range of values for the various vadose zone hydraulic properties indicates that sediments in the SNL/KAFB area exhibit wide variations, in part due to heterogeneities of the geologic system.

In terms of contaminant migration, there are known plumes located at shallow depths in the vadose zone beneath the CWL (chromium) and the MWL (tritium) believed to have migrated through the vadose zone in the liquid phase (i.e., dissolved in vadose zone water). In that the chromium and tritium have virtually no adsorption, they will travel at approximately the same velocity as the areal recharge rate. Additionally, there is one known instance of groundwater contamination at the CWL likely caused by volatile organics migrating through the vadose zone in the vapor phase and subsequently partitioning to the saturated zone. Preliminary calculations suggest that vapor-phase movement might be orders of magnitude faster than water-phase movement at the CWL (SNL/NM 1991b).

\subsubsection{Calendar Year 1992 Studies}

Glass et al. (1993) are developing an approach to characterize flow and transport phenomena within thick, unsaturated alluvial deposits such as those found in the SNL/KAFB area. Their approach involves incorporating both hydrologic-property and geologic data collected from local outcrops analogous to the site-specific geologic units found at ER sites. The broad geologic framework is established using conditional indicator simulation of lithofacies-scale geologic data. The hydrologic flow and transport properties of these lithofacies are then incorporated into lithofacies-specific conditional stochastic simulations. To test the viability of this proposed approach, Glass et al. (1993) performed preliminary studies in ancestral Rio Grande sediments found outcropping at the southwestern corner of Interstate-25 and Rio Bravo. Their preliminary work included (1) performing a large-scale field infiltration test, (2) mapping and describing the major geologic lithofacies, (3) obtaining laboratory measurement of the moisture characteristic curves and subsequent calculation of the unsaturated hydraulic conductivity versus moisture content relationship for five lithofacies, (4) using a tension infiltrometer to measure the saturated and unsaturated hydraulic conductivities of in situ $1,000-\mathrm{cm}^{3}$ volumes of undisturbed sediment, (5) measuring dye tracer dispersion and retardation of one lithofacies in laboratory columns, and (6) performing preliminary modeling of the large-scale experimental results using the smaller-scale laboratory hydraulic property measurements.

Several of the calendar year 1992 investigations performed at ER sites will also provide data to aid in our understanding of the regional vadose zone characteristics (Table 1-1). Unsaturated zone studies at the CWL focused on better definition of the volatile plume emanating from the landfill by performing a preliminary soil-gas survey at shallow depths [30 to $50 \mathrm{ft}(9$ to $15 \mathrm{~m})$ ]. Gas samples of five target VOCs were collected with a geoprobe and analyzed by gas chromatograph. Volatile organic contamination was found at depths of $50 \mathrm{ft}(15 \mathrm{~m})$ (Ardito et al. 1993). Second-phase soil-gas work involved boring to depths up to $240 \mathrm{ft}(73 \mathrm{~m})$, collecting both soil-gas data and soil samples for volatile organic analysis, 
as well as moisture content and geologic data. These results will be published after field activities have been completed in 1993 .

At the MWL, continuous core was collected to about $540 \mathrm{ft}(165 \mathrm{~m})$ beneath the landfill from an angle-drilled monitor well. Initial moisture content was collected from this core at 1 -ft intervals using a time-domain reflectometry device. Stable isotope data were collected from some of the core, and the grain size distribution, moisture characteristic curve, and saturated hydraulic conductivity were measured on one sample.

Lithologic and geophysical data collected during drilling activities conducted at TA-II, TA-III/IV, and along the South Fence Road (SFR) will aid in building the geologic framework for studying vadose zone flow and transport characteristics. In addition, quantitative geostatistical analysis of data obtained from the sanitary sewer-line trench mapping provides information about the lateral extent, thickness, and connectivity of the mapped geologic units (McCord et al. 1993).

\subsubsection{Additional Needs: Vadose Zone Characterization Plan}

As previously stated, there are many aspects of the vadose zone that are not fully understood; subsequently, our current conceptualization of flow and transport processes and our CM(s) for the vadose zone are limited. A vadose zone characterization task plan was written to provide the framework and justification for all future vadose zone characterization work (Parsons et al. 1993).

As stated in the task plan, vadose zone characterization work will be planned and prioritized according to the methodology described in Section 2.4. The specific objectives of future vadose zone studies are to (1) reduce the uncertainty in the risk that ER sites pose to human health and (2) establish the upper boundary condition for the saturated regional groundwater flow model. To reduce our uncertainty in the risk of individ al ER sites, pathways for contaminant migration through the vadose zone will be evaluated. To establish upper boundary conditions of the saturated zone, the uncertainty in the regional areal recharge will be reduced. These and future vadose zone characterization activities will provide input to the regional groundwater flow and transport $\mathrm{CM}$ development and subsequent numerical modeling efforts.

Specific vadose zone studies planned for fiscal year 1993 include determining vadose zone hydraulic and transport characteristics by initiating a series of induced infiltration studies. We also will begin determining vadose zone dispersion under natural conditions, as well as natural recharge studies, by starting long-term tracer tests and performing environmental tracer experiments.

\subsection{Saturated Zone Hydrology}

This section provides a summary description of the regional and SNL/KAFB installation-wide saturated zone hydrology. The first objective of this summary description is to define the conceptual framework for groundwater flow and transport on SNL/KAFB. The second objective is to identify the current state of knowledge of hydrologic characteristics and their 
associated uncertainties important to the quantitative understanding of potential pathways for groundwater transport of contaminants to local receptors that could cause adverse impacts on human health and safety.

The summary description presented in this section represents a synthesis of existing hydrogeologic reports and incorporates appropriate findings from ongoing investigations being carried out under the SNL/NM ER Program. Specific ER Program calendar year 1992 investigations that have contributed information to this synthesis include drilling and sampling projects in TA-II, TA-V [Liquid Waste Disposal Site (LWDS) project], and TA-III (the MWL and CWL projects) and the SFR drilling project.

\subsubsection{Regional Hydrology}

The following section summarizes the regional hydrology of the Albuquerque Basin. For more detailed discussions, the reader is referred to some of the numerous references on this subject. These references include the following: Birch (1980), Bjorklund and Maxwell (1961), Galusha and Blick (1971), Hearne and Dewey (1988), Kelly (1982), Kernodle et al. (1987), and Theis (1938).

The SNL/KAFB area is part of the Albuquerque Basin, located in central New Mexico (Figure 3-1). Estimates of the basin size range from approximately 2,500 to $4,000 \mathrm{mi}^{2}$ $\left(6,478\right.$ to $\left.10,365 \mathrm{~km}^{2}\right)$. The thickness of the basin fill is variable and can exceed $18,000 \mathrm{ft}$ (5,486 m) (Kernodle 1992).

The basin-fill Santa Fe Group deposits are the primary aquifer in the Albuquerque-Belen Basin. The basin-fill aquifer consists of interbedded gravel, sand, silt, and clay, and it is part of a complex stream-aquifer system that has been extensively developed in parts of the basin for irrigation, domestic, and municipal water supply. Values of hydraulic conductivity range from 0.25 to $50.0 \mathrm{ft} /$ day [0.08 to $15.2 \mathrm{~m} /$ day] (Kernodle and Scott 1986). The aquifer properties have a considerable range of values because of the large variations in lithology of the basin-fill deposits.

Anderholm (1987) identified the following four main sources of recharge to the basin-fill aquifer: (1) infiltration of surface water from arroyos along the basin margins, (2) infiltration of surface water from intermittent streams, (3) subsurface groundwater inflow, and (4) infiltration of water from the Rio Grande and from excess applied irrigation water (infiltration from irrigation canals is also included in this category). Infiltration of surface water from arroyos along the basin margins, or mountain-front recharge, is pointed out as providing the majority of recharge, with direct infiltration of precipitation in the inter-arroyo areas noted as a minor source.

Discharge from the basin-fill aquifer is the result of three major processes:

(1) evapotranspiration, (2) groundwater outflow to the Socorro Basin, and (3) groundwater pumpage (Anderholm 1987). Evapotranspiration from crops and native vegetation in the flood plain is the major consumptive use of water in the basin, although most evapotranspiration loss is from surface water rather than groundwater sources. Because Albuquerque, New Mexico's largest city, is in the basin, municipal, industrial, and domestic 
water use also are major uses of water, almost exclusively from groundwater (Kernodle 1992). A flow diagram illustrating recharge to and discharge from the basin-fill aquifer is shown in Figure 4-10 (Anderholm 1987).

Groundwater is generally unconfined in the upper part of the aquifer (where depth to groundwater is shallow). However, in the deeper parts of the aquifer, the water can be semiconfined or confined, due to heterogeneity in the aquifer. The depth to groundwater is quite variable in the basin. For instance, depth to water in the Rio Grande and Jemez River Valleys is generally less than $30 \mathrm{ft}(9.1 \mathrm{~m})$ and can be as shallow as $10 \mathrm{ft}(3.0 \mathrm{~m})$. However, depth to groundwater can vary from 300 to $900 \mathrm{ft}(91$ to $274 \mathrm{~m})$ in some areas on the East and West Mesas (Anderholm 1987).

The general direction of groundwater flow is shown in Figure 4-11. This figure shows the direction of flow to be from the basin margins toward the basin center (and subsequently the Rio Grande). Groundwater also flows southward toward the Socorro Basin. In the vicinity of the Jemez River, groundwater flows southeastward approximately parallel to the Jemez River (Anderholm 1987).

Hydraulic gradients are quite variable throughout the basin, with steep gradients being found along the western margin and relatively flat gradients near the center of the basin.

Groundwater along the eastern side of the basin is perched on a structural bench covered with a relatively thin layer of basin-fill deposits. In some areas along the bench there is a difference of approximately $500 \mathrm{ft}(152 \mathrm{~m})$ in water levels across a faul ${ }^{\star}$ complex that separates the bench from more permeable basin-fill deposits to the west (Anderholm 1987).

\subsubsection{SNL/KAFB Saturated Zone Hydrogeologic Framework}

SNL/KAFB is situated in an area that includes two very different geologic environments separated by an assemblage of fault systems (see Section 3.0). This melange of geologic elements contributes to a complex saturated zone hydrogeologic framework. In Section 3.4.2, this framework was divided into three distinct hydrogeologic regions based on local geology (see Figure 3-17). This hydrogeologic framework establishes the basis for the CM discussed in this section. This CM identifies four subareas (Figure 4-12) within these three hydrogeologic regions that are defined by a mix of hydrologic characteristics that strongly impact the local saturated zone hydrology. Two of these subareas (subareas 1 and 2) are located in HR1 and are distinguished by the local transients caused by water-supply pumping wells. The other two subareas correspond to HR2 (subarea 3) and HR3 (subarea 4).

Hydrologic characteristics considered in defining these subareas include differences in flow systems (porous media flow and fracture flow), the type(s) of aquifers (unconfined/perched and confined), the state of the flow system (steady-state and transient), flow system boundaries, and flow system heterogeneities and anisotropies.

\subsubsection{Subareas 1 and 2: Santa Fe Group Framework}

Subareas 1 and 2 (Figure 4-12) share a common hydrogeologic framework defined by Santa Fe Group hydrostratigraphy. The most recent and detailed discussion of Santa Fe Group hydrostratigraphy is included in Hawley and Haase (1992), which is the basis for the 


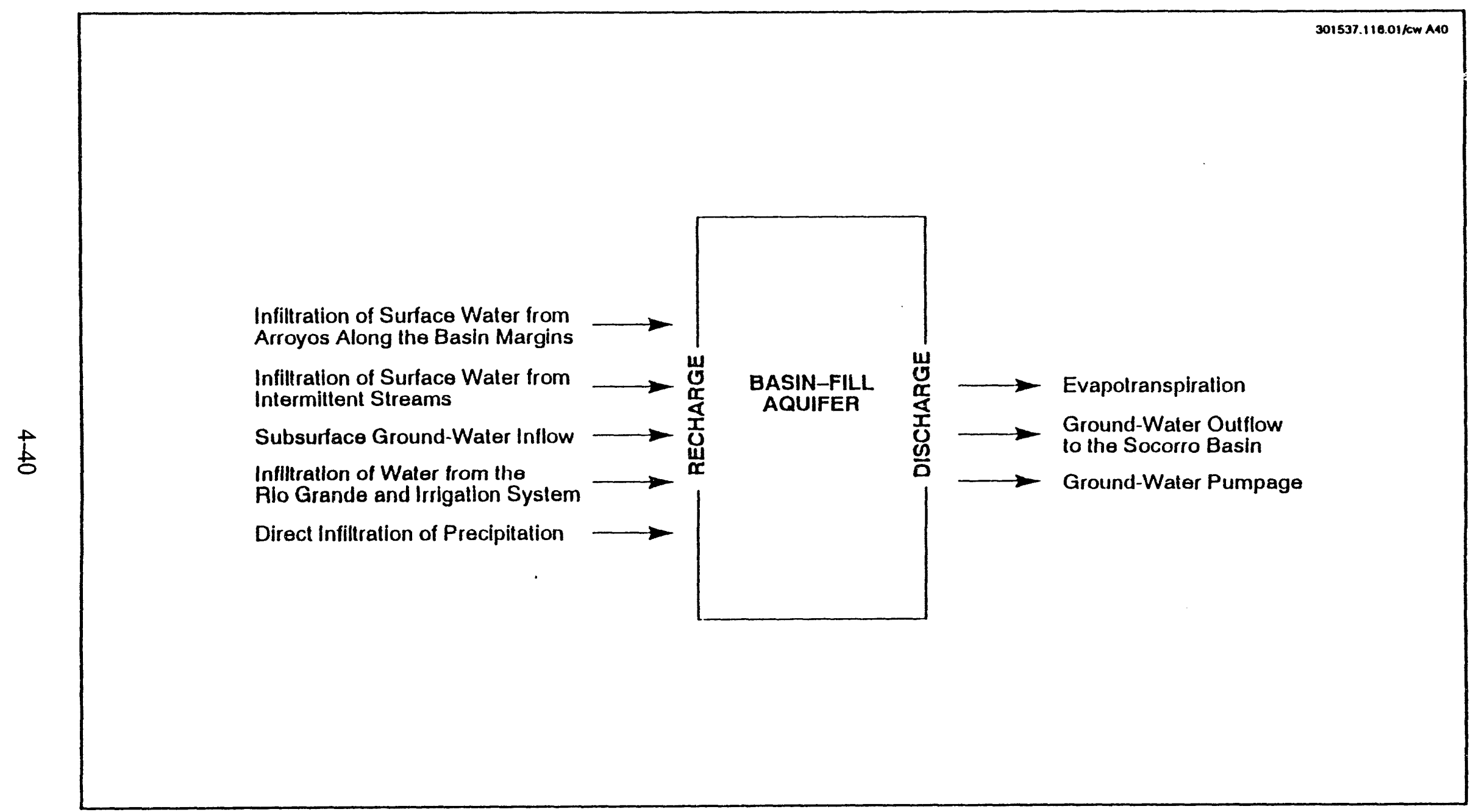

Figure 4-10. Flow Diagram of Recharge to and Discharge from the Basin-Fill Aquifer 


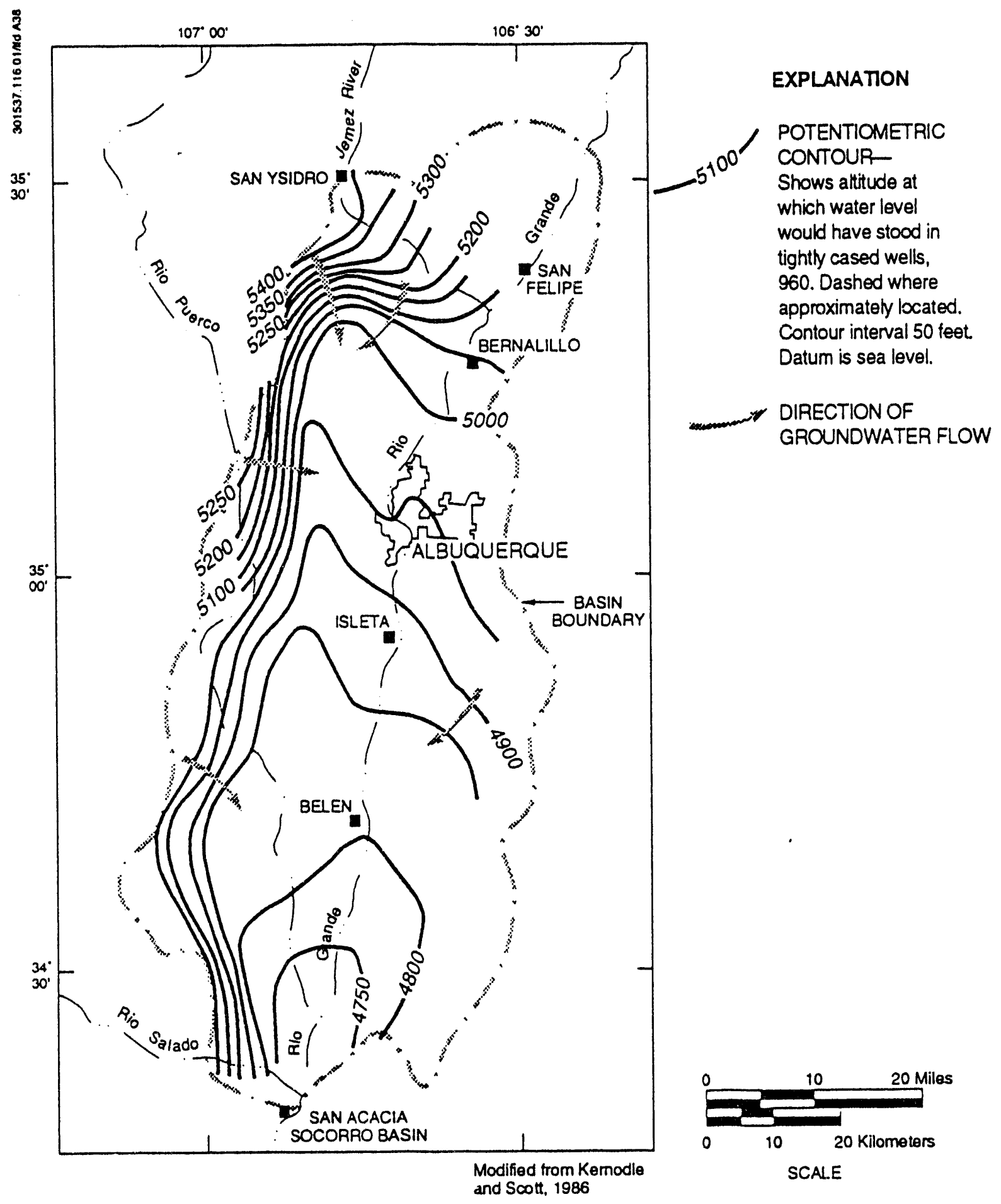

Figure 4-11. Potentiometric Surface of the Albuquerque Basin-Fill Aquifer 


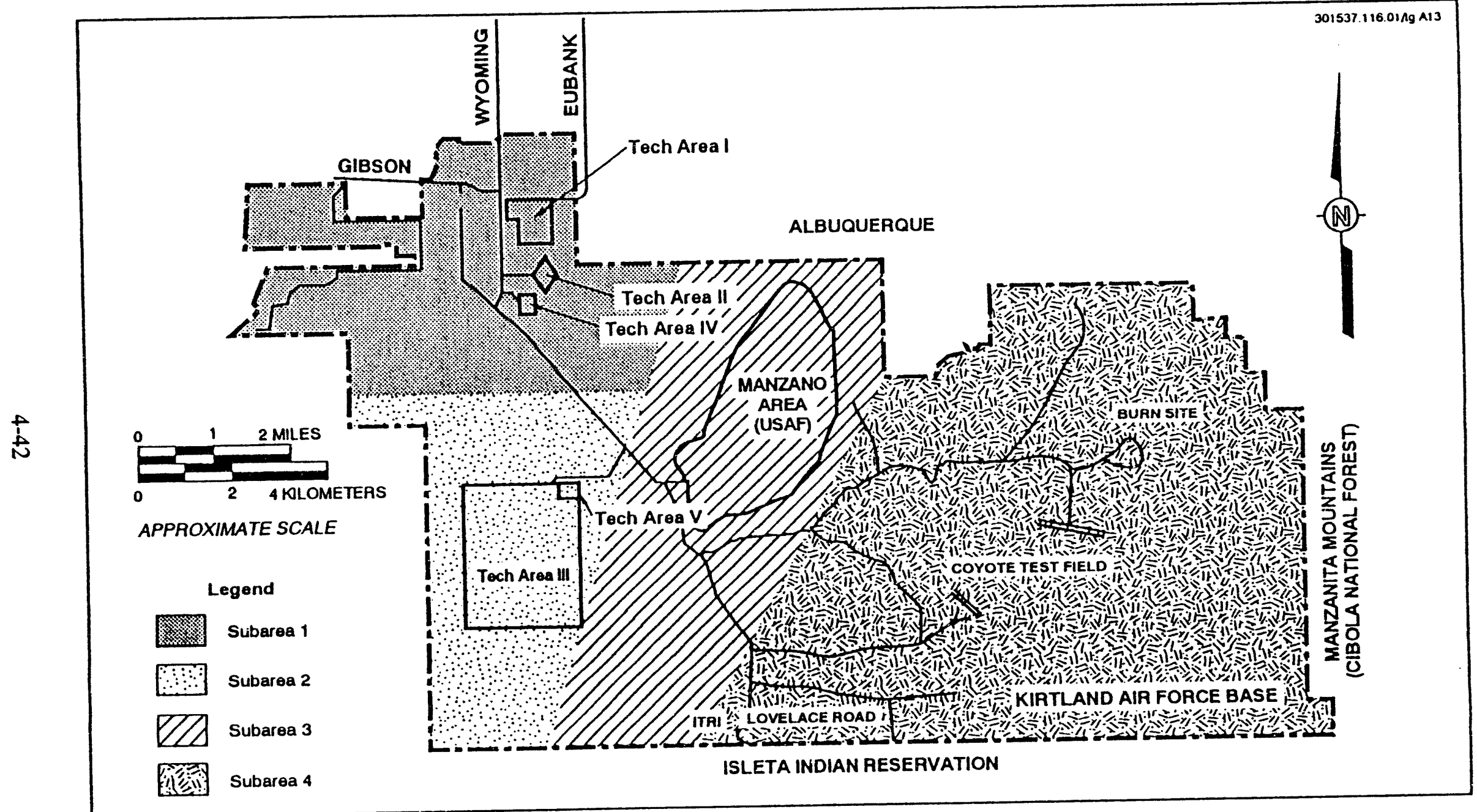

Figure 4-12. Locations of Subareas Considered in the SNL/NM Saturated Zone Characterization 
discussion in Section 3.4. Other appropriate references include Kelley (1977), Kernodle and Scott (1986), Kernodle et al. (1987), Lozinsky (1988), and SAIC (1985).

The uppermost aquifer underlying subareas 1 and 2 is within the upper Santa Fe Group and is generally assumed to be an unconsolidated to partially indurated, porous media aquifer. Based on the discussion in Section 3.4, this aquifer can be further assumed to be composed of a heterogeneous mix of coarse to very fine-grained lithologies that exhibit a complex architectural framework characterized by a variability in bedding thickness, continuity, and connectivity. Existing subsurface lithostratigraphic data from subareas 1 and 2 support this characterization. Figure 4-13 shows a lithologic column typical for these subareas down to a depth of $365 \mathrm{ft}(111 \mathrm{~m})$. This lithologic information was obtained at the SFR-2 borehole drilled as part of the 1992 SFR project.

Other 1992 ER Program projects that obtained lithologic data include projects at TA-II, TA-V (LWDS), and TA-III (CWL and MWL). Table 4-5 identifies 1992 ER Program boreholes for which lithologic data is available.

An additional assumed characteristic of the uppermost major Santa Fe Group aquifer is that it is unconfined. However, a review of borehole data from 1992 investigations suggests that this assumption is not appropriate at every location. At SFR-1, the uppermost major aquifer is confined. At this location, the aquifer was encountered below a moderately to strongly cemented conglomerate at a depth of approximately $317 \mathrm{ft}(96.6 \mathrm{~m})$. After completion of this interval as a monitoring well (SFR-1D), a stable water level of approximately $139.5 \mathrm{ft}$ $(42.5 \mathrm{~m})$ below ground surface was measured. This indicates that the potentiometric surface for the uppermost major aquifer at this location rises approximately $178 \mathrm{ft}(54.3 \mathrm{~m})$ above its confining layer (Neel and McCord 1993). In addition, field data from LWDS-MW2 and MWL-MW4 wells suggest that the uppermost major aquifer at these sites appears to be at least partially confined. In both of these boreholes, the water level rose above the depth where the saturated zone was first encountered. In addition, core moisture data from SFR-1, SFR-2, and SFR-3 wells (Neel and McCord 1993) suggest the potential for perched, saturated intervals above the uppermost major aquifer. Figure 4-14 shows the relative core moisture versus depth as identified in the core lithologic descriptions for these three boreholes. Possible perched intervals are indicated by very moist to wet intervals underlain by slightly moist to dry intervals. Both of these characteristics (i.e., locally confined conditions and potential perched saturation intervals) indicate that the assumption that the uppermost major Santa Fe Group aquifer is unconfined might not be appropriate at all locations.

Subareas 1 and 2 are both located in HR1. What distinguishes these subareas is the local drawdown produced by water-supply pumping wells located in the northwest part of SNL/ KAFB (Figure 4-15). These transient effects will more strongly affect groundwater flow in subarea 1 and will need to be explicitly considered in the assessment of local RFI sites. Figure 4-16 shows annual hydrographs from two monitor ing wells in subarea 1 (LF/DM-01 and LF/DM-02). Transient pumping effects were also considered in a 1991 scoping study associated with evaluating flow direction and travel times in the vicinity of TA-II (INTERA 1991). The results of this study were considered inconclusive. 


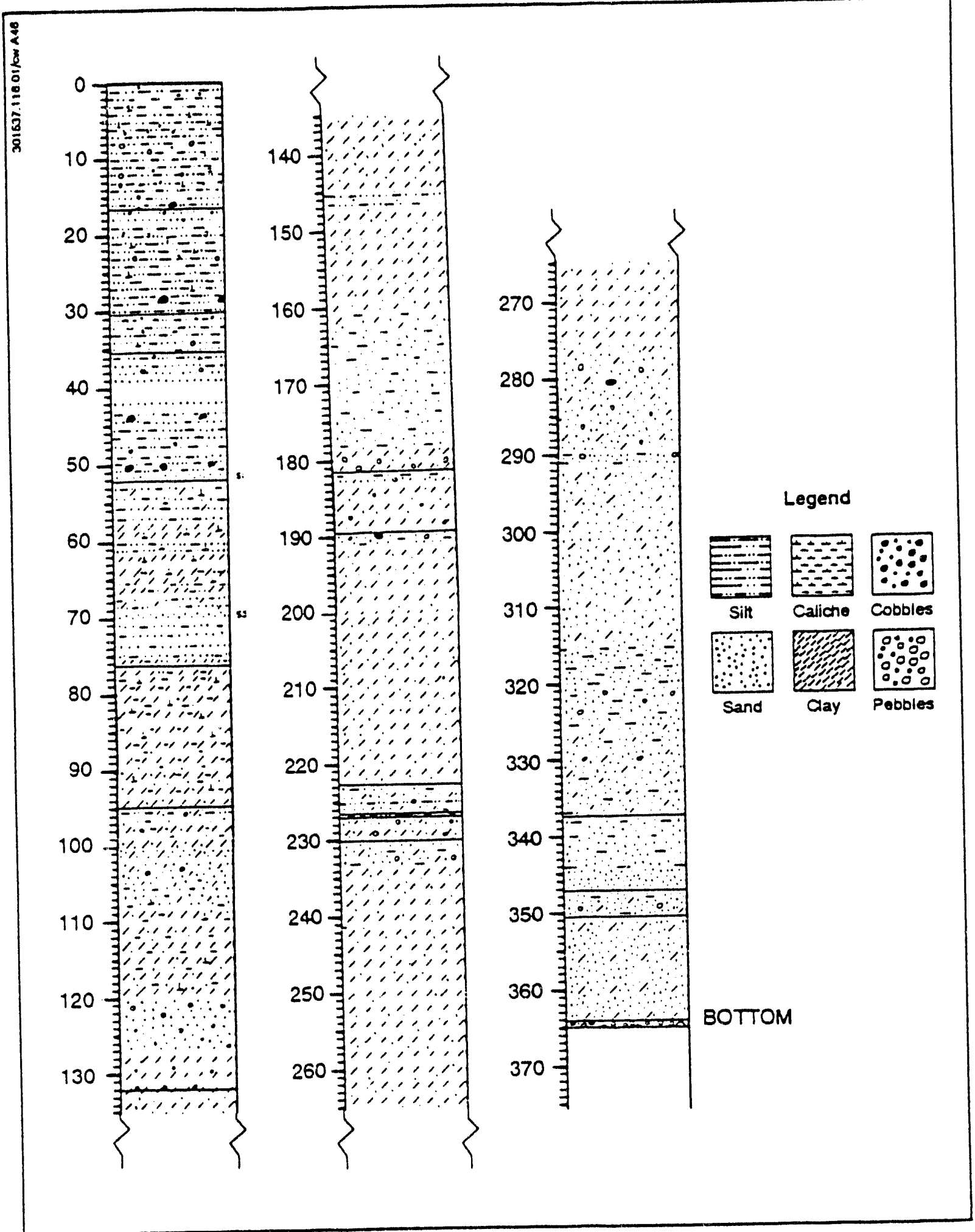

Figure 4-13. Typical Lithologic Column for the Santa Fe Group in the South Fence Road Region 
Table 4-5

Summary of Santa Fe Group Lithostratigraphic Data Obtained from 1992 ER Program Boreholes

\begin{tabular}{|c|c|c|}
\hline BOREHOLE & $\begin{array}{l}\text { DEPTH } \\
(\mathrm{ft})\end{array}$ & LITHOSTRATIGRAPHIC DATA \\
\hline \multicolumn{3}{|c|}{ South Fence Road Project } \\
\hline SFR-1 & 510 & $\begin{array}{l}\text { - Continuous core } 0 \text { to } 317 \mathrm{ft} \\
\text { - Cuttings } 317 \text { to } 510 \mathrm{ft}\end{array}$ \\
\hline SFR-2 & 365 & - Continuous core 0 to $365 \mathrm{ft}$ \\
\hline SFR-3 & 408 & - Continuous core 0 to $408 \mathrm{ft}$ \\
\hline \multicolumn{3}{|c|}{ Liquid Waste Disposal Site Project } \\
\hline LWDS-MW2 & 525 & $\begin{array}{l}\text { - Continuous core } 0 \text { to } 500 \mathrm{ft} \\
\text { - Cuttings } 500 \text { to } 525 \mathrm{ft}\end{array}$ \\
\hline $\begin{array}{l}\text { Five } 100-\mathrm{ft} \text { sample } \\
\text { boreholes }\end{array}$ & 100 (each) & - Continuous core \\
\hline $\begin{array}{l}\text { Three angled, } 50-\mathrm{ft} \\
\text { sample boreholes }\end{array}$ & 50 (each) & - Continuous core \\
\hline \multicolumn{3}{|c|}{ Technical Area II Project } \\
\hline SW 1-320 & 330 & - Continuous core 0 to $330 \mathrm{ft}$ \\
\hline \multicolumn{3}{|c|}{ Mixed Waste Landfill } \\
\hline MWL-MW4 & 546 & - Continuous core 0 to $546 \mathrm{ft}$ \\
\hline \multicolumn{3}{|c|}{ Chemical Waste Landfill Project } \\
\hline $\operatorname{CWL}(-30,-20)$ & 135 & - Continuous core 0 to $135 \mathrm{ft}$ \\
\hline CWL $(-75,-15)$ & 185 & - Continuous core 0 to $185 \mathrm{ft}$ \\
\hline Ten sample boreholes & 102.5 to 222.5 & - Samples from 5 to $20 \mathrm{ft}$ intervals \\
\hline
\end{tabular}




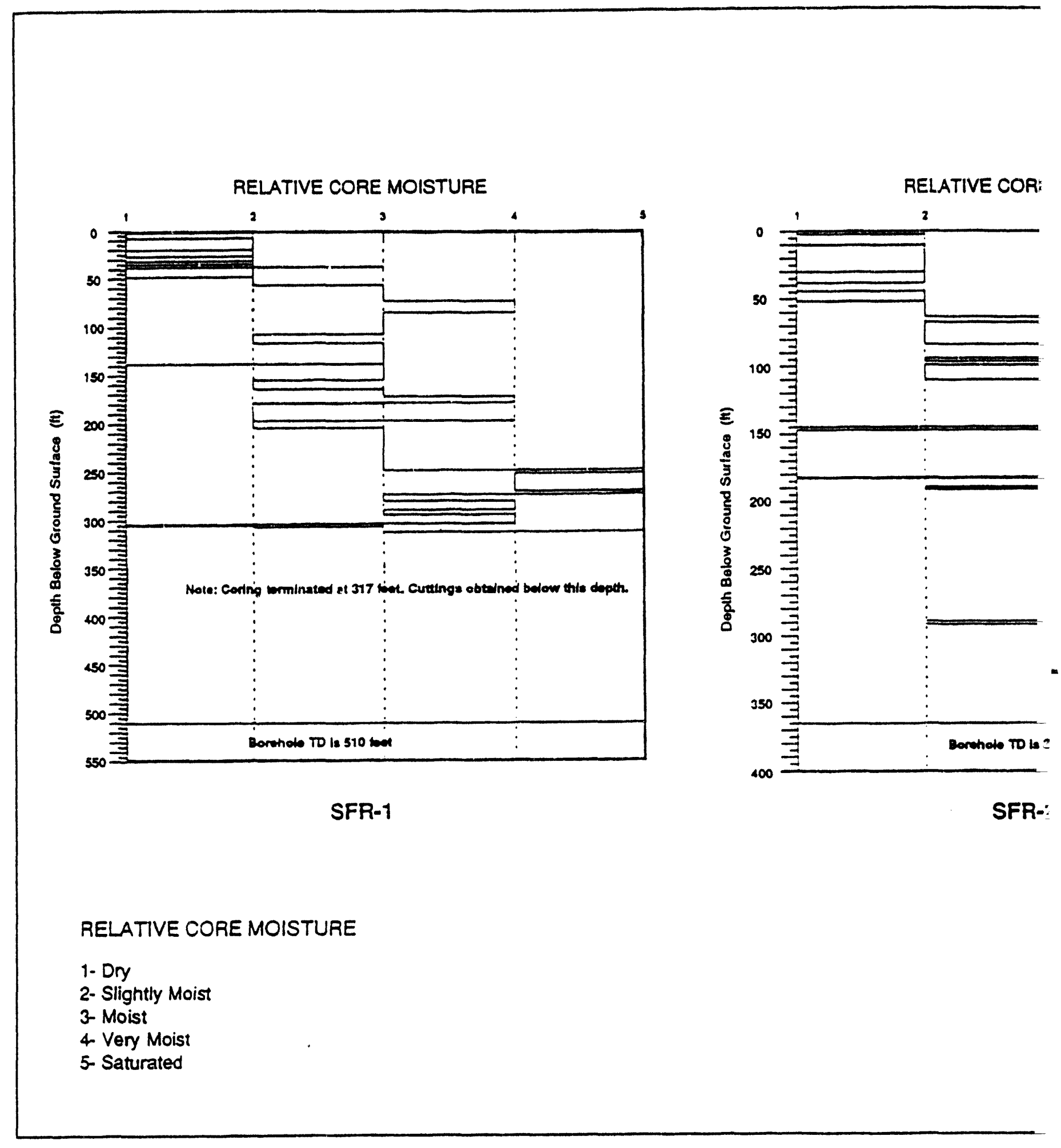

Figure 4-14. Relative Core Mois 


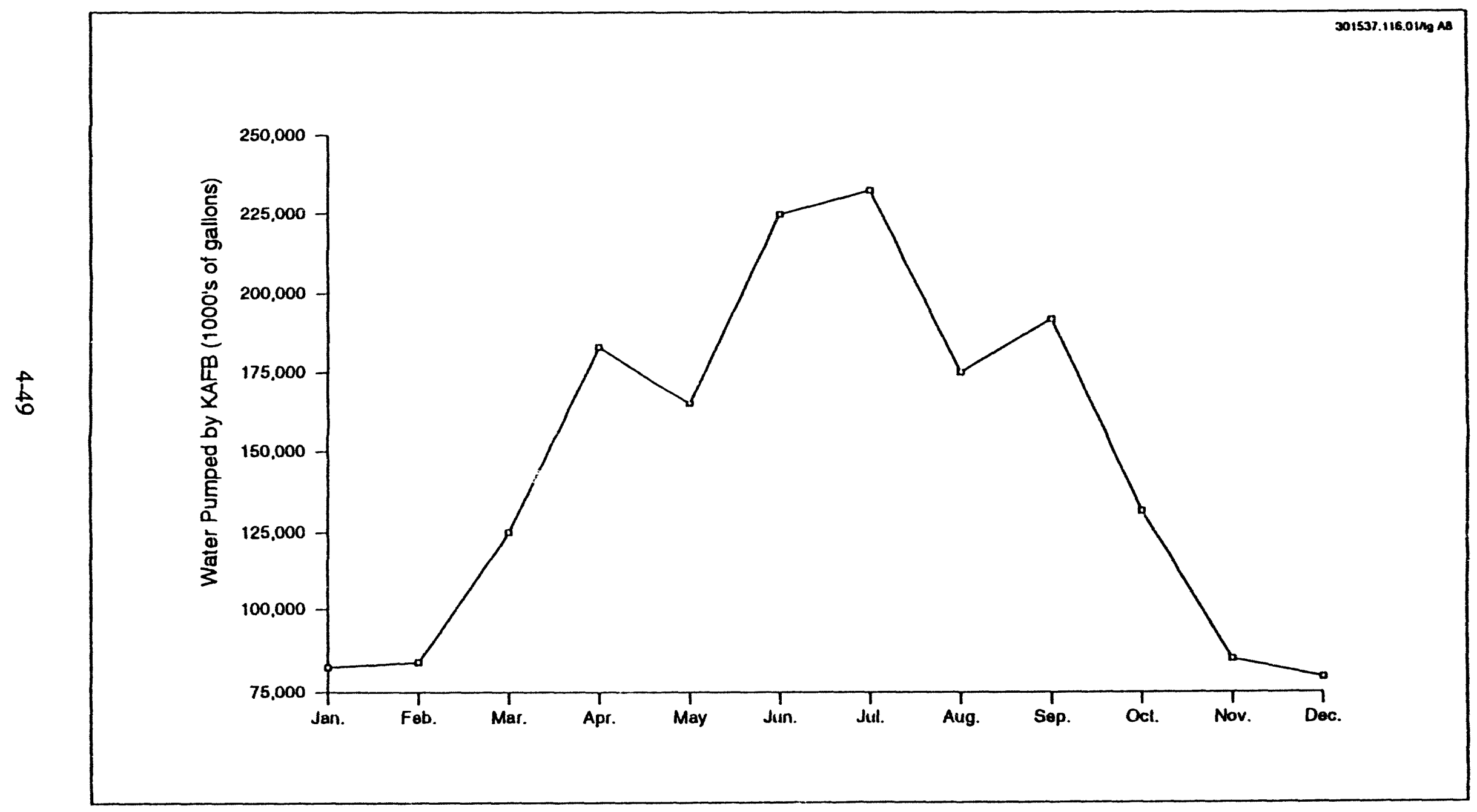

Figure 4-15. Water Pumped by KAFB Production Wells in 1992 


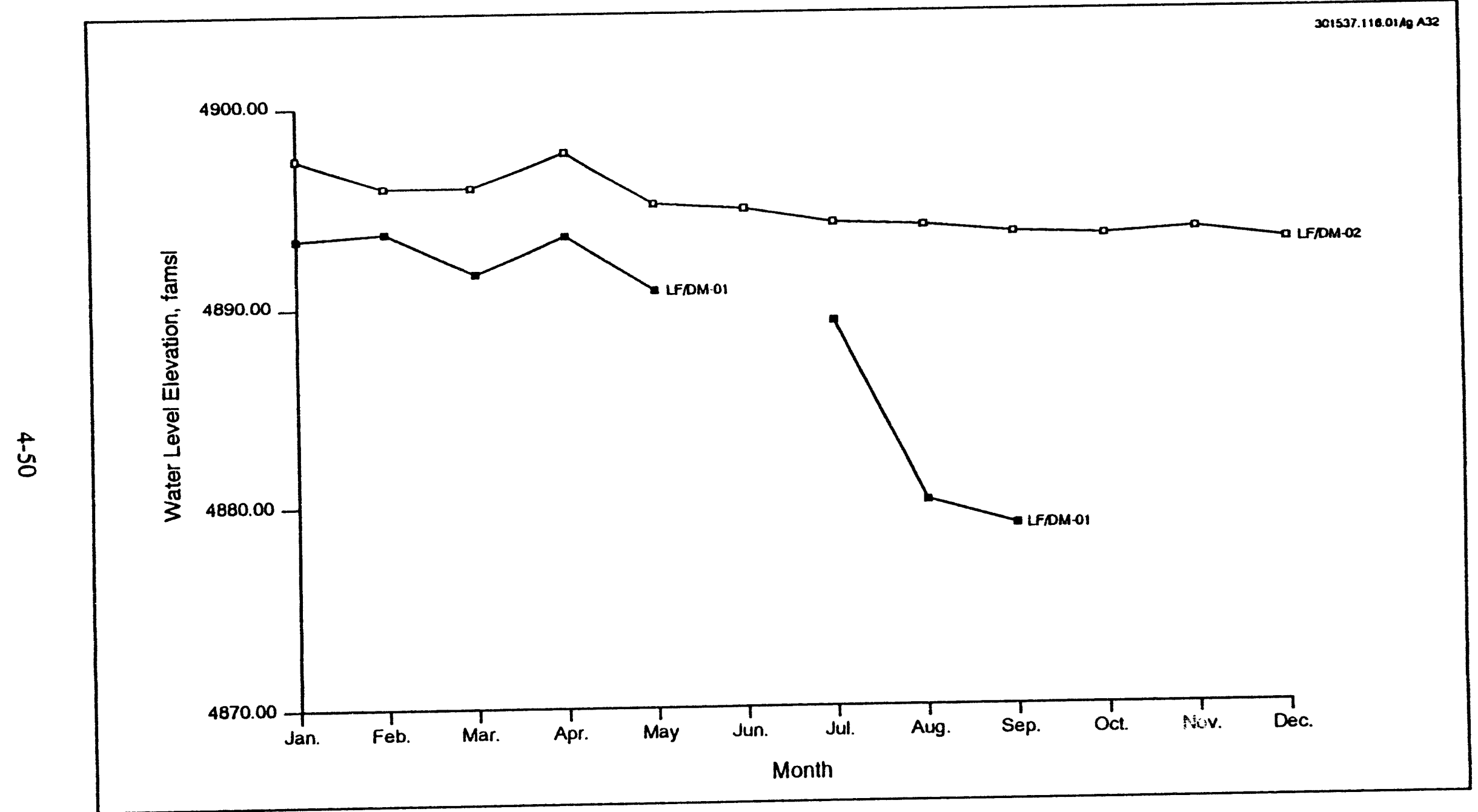

Figure 4-16. Hydrographs for Two Monitoring Wells Within Subarea 1, 1992 
As suggested in the previous discussion of the Santa Fe Group underlying subareas 1 and 2, at least three significant uncertainties exist in the current hydrogeologic $\mathrm{CM}$. The first major uncertainty is associated with the potential for significant high-permeability flow paths (i.e., elongate channel deposits) to exist within the heterogeneous lithostratigraphic fabric of the Santa Fe Group. The second major uncertainty involves the conceptualıation of the Santa Fe Group aquifer as unconfined or confined. The third major uncertainty is with the current understanding of the transient impacts of the water-supply pumping wells in northwest SNL/KAFB.

\subsubsection{Subarea 3: Fault Complex Framework}

Subarea 3 includes a north-south band across SNL/KAFB that brackets the Tijeras/Hubbell Spring/Sandia Fault complex (Figure 4-12), and corresponds to HR2 in Section 3.4. The subsurface geology in this subarea includes Santa Fe Group sediments to the west and Paleozoic/Precambrian bedrock to the east. The saturated zone hydrology will be characterized by a flow system complicated by the juxtaposition of contrasting stratigraphic units across one or more faults. This faulting includes both north-south-trending, extentional, down-to-the-west normal faults (the Sandia and Hubbell Spring Faults) and the northeastsouthwest-trending Tijeras Fault, a left-lateral wrench fault that exhibits a "scissoring" block rotation (see Section 3.2). Appropriate references related to the hydrogeologic framework in this subarea include Anderholm (1988), Grant (1982), Kelley (1977), Kelley and Northrop (1975), Lozinsky (1988), Riddle and Grant (1981), and Titus (1963).

Very little is currently known about saturated zone groundwater flow within this subarea. What is known is that there seems to be a significant change in the depth to the saturated zone across the fault complex. East of the fault complex, the depth to groundwater ranges from ground surface at Coyote and Sol se Mete springs to $158 \mathrm{ft}(48 \mathrm{~m})$ at monitoring well TSA-1. In areas west of the fault complex, the depth to the saturated zone is typically between 400 and $500 \mathrm{ft}$ (122 to $153 \mathrm{~m})$.

The primary CM of saturated zone flow across the fault complex is found in Titus (1963) and Anderholm (1988). In general, this model considers the fault complex as a hydraulic discontinuity between a shallow bedrock aquifer on the east and a deeper alluvial aquifer on the west. The shallow groundwater system in Paleozoic/Precambrian bedrock units flows westward from the Manzanita Mountains across the fault complex and recharges the deeper Santa Fe Group aquifer. The abrupt change in water levels across this zone results in a locally high groundwater gradient. Another CM of groundwater flow in this region suggests that in the past the fault complex provided a conduit for upward flow of deep thermal water (Grant 1982). This model is supported by the presence of extensive secondary carbonate deposits (Travertine Hills) near the intersection of the Sandia, Tijeras, and Hubbell Spring Faults. The lack of numerous active springs suggests that this upward flow system has either been choked off, possibly by carbonate deposition, or that it is still active but is being overridden by the downward flow of low-temperature groundwater from east of the fault zone. Both of these CMs demonstrate that the fault complex is expected to strongly impact the local saturated zone hydrology. 
The 1992 ER Program SFR project was implemented to help characterize the impact of the fault complex on the saturated zone hydrology along the southern boundary of SNL/KAFB (Neel and McCord 1993). This project involved installing a line of monitoring wells across the fault complex. Well placement was guided by an interpretation of a 1991 gravity survey (IT 1991). Figure 4-17 shows the surface gravity transects in the southern portion of SNL/KAFB. The SFR project boreholes were placed along Transect 5 in the approximate locations shown. Figure 4-18 shows a cross section through the SFR boreholes showing estimated depth-to-bedrock profiles based on two different gravity data interpretations (IT 1991, 1992). Table 4-6 shows a comparison of the SFR borehole depths to these depth-tobedrock interpretations. As noted in a footnote to this table, bedrock was encountered only in SFR-4. Therefore, this project has not yet provided data on local bedrock displacement across the fault complex. Additionally, the saturated zone was not encountered in SFR-4. Therefore, the local variation in saturated zone water levels across the fault complex has not yet been established.

Table 4-6

Summary of South Fence Road Borehole Depths and Gravity Data Interpretations

\begin{tabular}{|c|c|c|c|}
\hline & \multirow{2}{*}{$\begin{array}{c}\text { TOTAL } \\
\text { DEPTH } \\
\text { [ft bgl] }\end{array}$} & $\begin{array}{r}\text { BEDROCK DEPTH ESTIMATE } \\
\text { FROM GRAVITY DATA } \\
(\mathrm{ft} \text { bgl) }\end{array}$ \\
\cline { 3 - 4 } & $\begin{array}{c}\text { INITIAL } \\
(1991)\end{array}$ & $\begin{array}{c}\text { REVISED } \\
(1992)\end{array}$ \\
\hline \hline SFR-1 & $510^{1}$ & 280 & 667 \\
\hline SFR-2 & $365^{1}$ & 190 & 455 \\
\hline SFR-3 & $408^{1}$ & 158 & 408 \\
\hline SFR-4 & $168^{2}$ & 23 & 229 \\
\hline
\end{tabular}

1. Bedrock not penetrated.

2. Weathered shales and mudstone (possible Abo or Yeso Formation) penetrated at a depth of 40 to $50 \mathrm{ft}$.

As indicated in the previous discussion, there are significant uncertainties in the current understanding of saturated zone groundwater flow across subarea 3. These uncertainties range from a lack of basic data on the bedrock and water-level geometry across the fault complex to questions concerning the impact of faulting on local hydraulic parameters and local flow-system boundary conditions. All of these factors will be important in understanding the potential for groundwater transport of possible contaminants across this fault complex. 


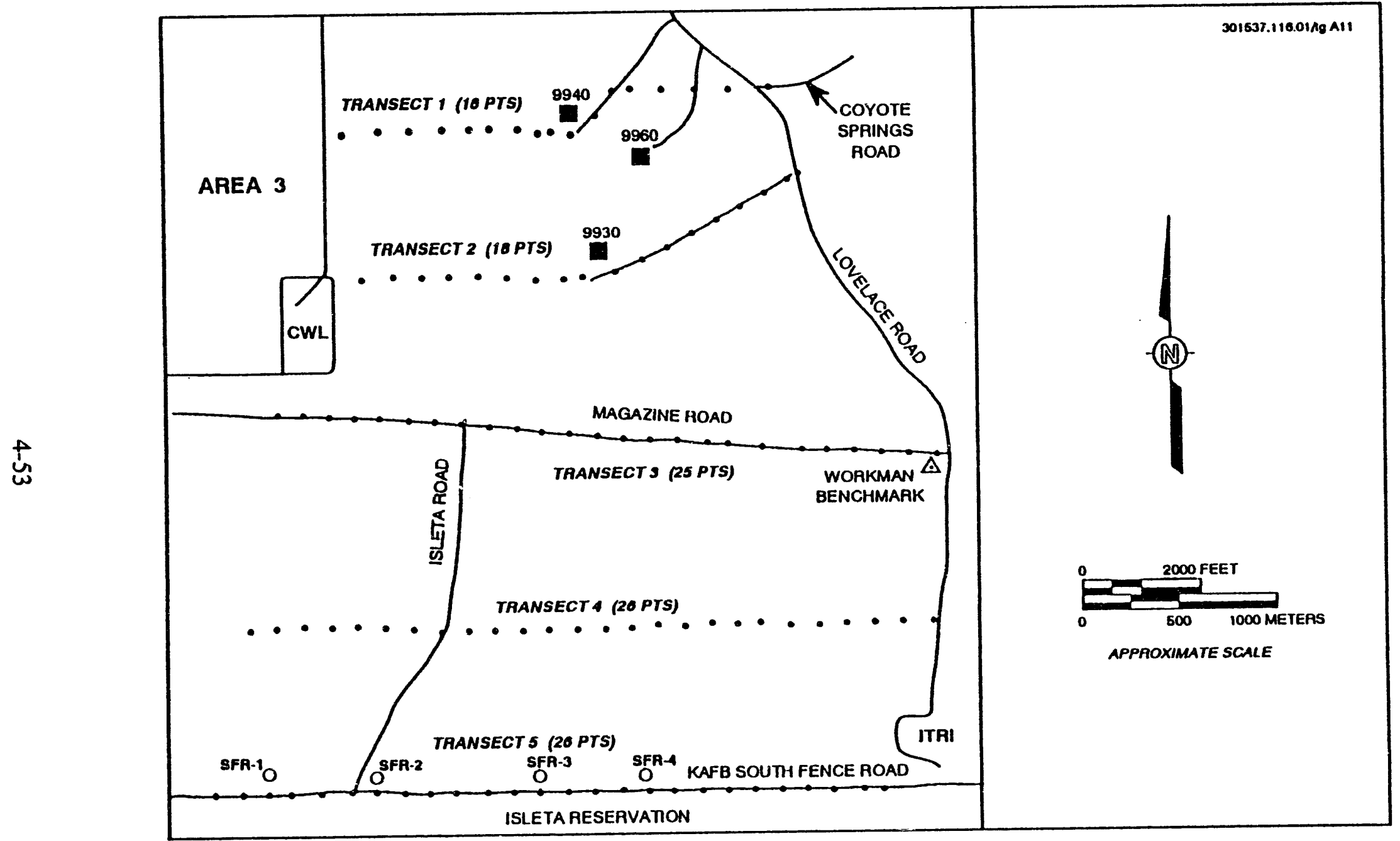

Figure 4-17. Gravity Survey Transects 


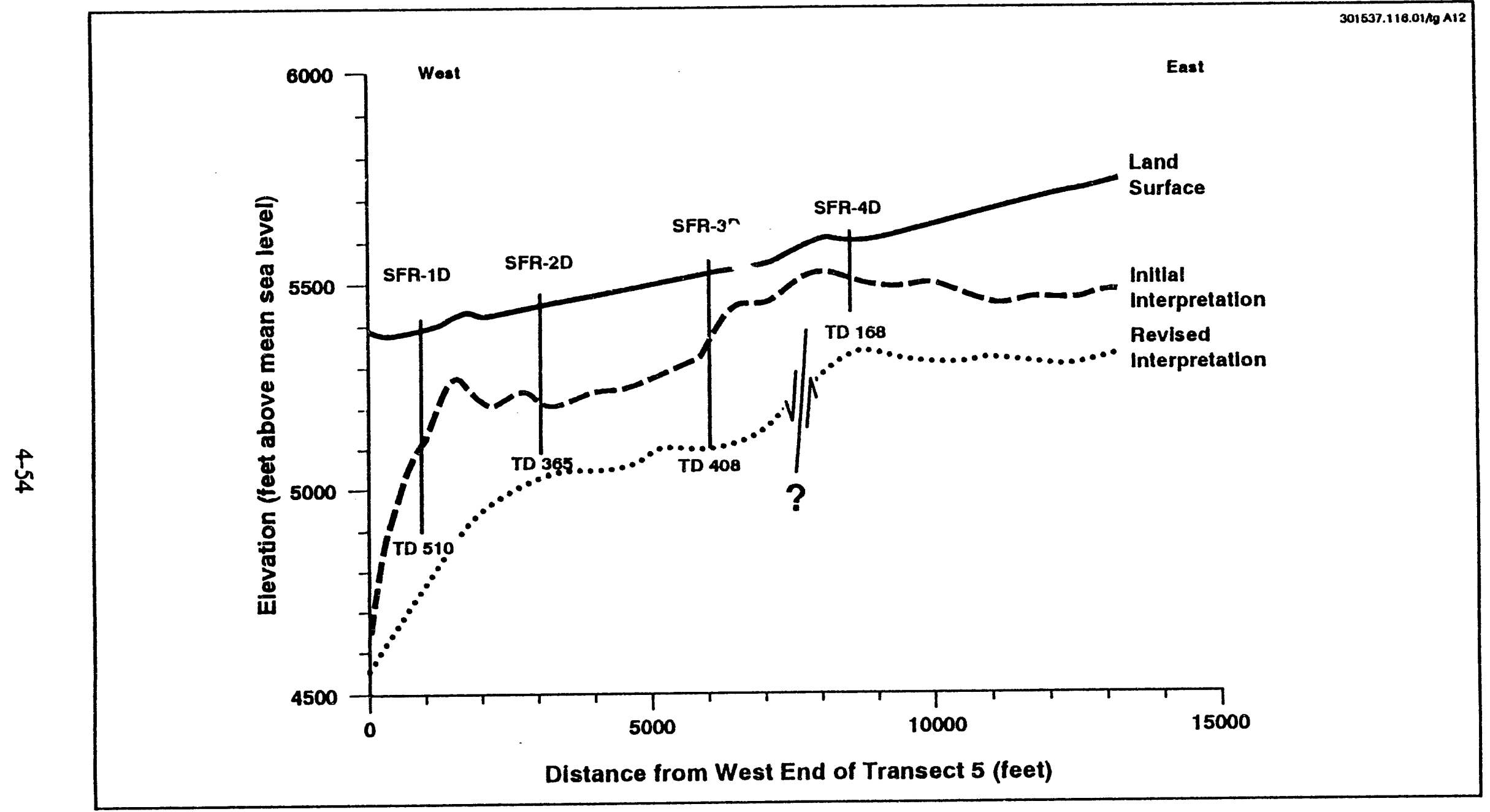

Figure 4-18. Land Surface Elevation and Predicted Top-of-Bedrock Elevation Along Transect 5 


\subsubsection{Subarea 4: Paleozoic/Precambrian Bedrock Framework}

Subarea 4 is located in the eastern portion of SNL/KAFB and includes the USFS withdrawn area (Figure 4-12). This subarea corresponds to HR3 in Section 3.4. The bedrock stratigraphy includes the Paleozoic Yeso, Abo, and Sandia Formations, and Madera Group and Precambrian igneous and metamorphic rocks. This general stratigraphic framework is complicated by faulting. Overlying the bedrock is a thin veneer of piedmont alluvial material. The saturated zone hydrology might include a shallow, unconfined alluvial aquifer (especially along the major drainages) and multiple confined bedrock aquifer systems. These systems might include one or more confined porous media aquifers in the sandstones of the Paleozoic units (Yeso, Abo, and Sandia Formations), and one or more confined fracture zone aquifers in the Paleozoic Madera limestone and Precambrian rocks. Appropriate references related to the hydrogeologic framework of this subarea include Cavin et al. (1982), Kelley (1977), Kelley and Northrup (1975), Myers and McKay (1970), Myers and McKay (1976), Reiche (1949), and Titus (1980).

What is currently known about the saturated zone hydrology in subarea 4 is limited to borehole data from widely scattered locations and a site-specific hydrogeological study at the ITRI (PRC 1990). Table 4-7 identifies the existing boreholes in this subarea. Table 4-8

Table 4-7

Identification of Boreholes in Subarea 4

\begin{tabular}{|c|c|c|c|}
\hline WELL NAME & $\begin{array}{c}\text { LOCATION } \\
\text { (New Mexico State } \\
\text { coordinates) }\end{array}$ & $\begin{array}{l}\text { GROUND } \\
\text { LEVEL } \\
\text { ELEVATION } \\
\text { (ft msl) }\end{array}$ & $\begin{array}{l}\text { TOTAL } \\
\text { DEPTH } \\
\text { (ft bgl) }\end{array}$ \\
\hline Burn Site Well & $x=453309.45 \quad y=1457027.32$ & 6.371 & 350 \\
\hline TSA-1 & $x=443186.62 \quad y=1456294.92$ & 6,060 & 303 \\
\hline Greystone Manor & $x=432117.05 \quad y=1454185.90$ & 5,818 & 54 \\
\hline EOD & $x=426599.27 \quad y=1448039.90$ & 5,827 & 212 \\
\hline Lake Christian West & $x=427752.80 \quad y=1442618.36$ & 5,713 & 72 \\
\hline School House Mesa & $x=431771.48 \quad y=1451215.82$ & 5.802 & 107 \\
\hline ITRI MW-1 & $x=423942.08 \quad y=1436734.78$ & 5,628 & 125 \\
\hline ITRI MW-2 & $x=426571.83 \quad y=1436310.16$ & 5.692 & 189 \\
\hline ITRI MW-3 & $x=423946.62 \quad y=1437500.01$ & 5,631 & 129 \\
\hline ITRI MW-4 & $x=423596.67 \quad y=1437116.87$ & 5,620 & 110 \\
\hline ITRI MW-5 & $x=424602.23 \quad y=1437228.86$ & 5,649 & 141 \\
\hline ITRI MW-6 & $x=423557.81 \quad y=1436164.77$ & 5,620 & 127 \\
\hline [TRI MW-7 & $x=424403.42 \quad y=1437686.86$ & 5,642 & 157 \\
\hline
\end{tabular}


summarizes hydrologic information available from these boreholes. Additional to the boreholes identified in these tables are several other KAFB boreholes for which information is currently unavailable (e.g., Optical Range Well, USGS Seismic Station, and HERTF well). Information from these boreholes will be included in the ER Program database and assessed as it becomes available.

Review of Table 4-8 identifies three, and possibly four, aquifer types. The Burn Site and TSA-1 wells produce groundwater from fractured zones in Precambrian rock. Comparison of the producing interval and static water levels in these wells indicates that these production intervals are confined. The EOD well produces groundwater from a fractured and possibly karstic zone in Paleozoic limestone. This production interval is also confined. The Greystone Manor well probably produces from unconfined alluvium. The Lake Christian well and the ITRI monitoring wells are completed in alluvial material and/or weathered Paleozoic bedrock (Yeso or Abo Formations). For all of the ITRI wells, the static water level is 16 to $36 \mathrm{ft}(4.9$ to $11 \mathrm{~m})$ above the depth in the well where water was first encountered. This suggests that this aquifer is confined and that it might be in weathered bedrock.

Currently there are significant uncertainties in the understanding of the overall hydrogeologic framework for subarea 4 . These uncertainties include incomplete knowledge on the distribution and interrelationships of the bedrock geology and a lack of information on the overall aquifer system. It is probable that this aquifer system includes shallow unconfined tlow and both porous-media and fractured-rock confined flow. This mixture of different aquifer types suggests that more than one model for groundwater flow will be required to define the flow systems in this subarea.

\subsubsection{Flow Parameters}

In gentral, it is difficult to predict the flow parameters of both the basin-fill material and the Paleozoic/Precambrian bedrock of the SNL/KAFB area. The difficulty in assessing aquifer characteristics such as hydraulic conductivity, storativity, and porosity in the porous media lies in the heterogeneities inherent in a fluvial depositional environment. Textural variations as the result of shifting stream channels and variable channel velocities cause widespread distribution of hydraulic properties. The bedded character of fluvial deposits imparts a strong anisotropy to the system. In addition, for extensive deposits such as the Santa Fe Group, allowances must be made for changes in permeability of the material with depth due to compaction caused by overlying sediments. Differences in aquifer parameters from one location to another can vary by several orders of magnitude, making prediction of these parameters speculative at best without site-specific information (Freeze and Cherry 1979).

Flow parameters in the Paleozoic/Precambrian bedrock are dominated by fracture flow phenomena, which can be difficult to evaluate with accuracy. Evaluation of flow parameters such as hydraulic conductivity can be made easier if the fracture density and connectivity is sufficiently high such that the fractured media acts hydraulically similar to porous media. Conversely, irregular spacings of the fractures cause the media to exhibit trending heterogeneity; fractures that differ in angle and direction further compound the problem by introducing anisotropy to the system (Freeze and Cherry 1979). The geologic environment of the SNL/KAFB region suggests that the tendency toward heterogeneity as well as 
Table 4-8

Summary of Hydrologic Characteristics of Boreholes in Subarea 4

\begin{tabular}{|c|c|c|c|}
\hline WELL NAME & $\begin{array}{l}\text { PRODUCING } \\
\text { FORMATION }\end{array}$ & $\begin{array}{l}\text { PRODUCING } \\
\text { INTERVAL } \\
\quad(f t \text { bgl })\end{array}$ & $\begin{array}{c}\text { PRODUCTION } \\
\text { INTERVAL } \\
\text { CHARACTERISTICS }\end{array}$ \\
\hline Burn Site Well & Precambrian & 222 to 350 & $\begin{array}{l}\text { Depth to water }=68 \mathrm{ft} \\
\text { - Production from fractures in schists } \\
\text { and granite }\end{array}$ \\
\hline TSA-1 & Precambrian & $\begin{array}{l}180 \text { to } 220 \\
260 \text { to } 300\end{array}$ & $\begin{array}{l}\text { Depth to water }=159 \mathrm{ft} \\
\text { - Production from fractures in schists } \\
\text { and granite }\end{array}$ \\
\hline Greystone Manor & Shallow alluvium & 0 to 54 & $\begin{array}{l}\text { - Depth to water }=54 \mathrm{ft} \\
\text { - Production from saturated alluvium }\end{array}$ \\
\hline EOD & Madera limestone & 204 to 212 & $\begin{array}{l}\text { - Depth to water }=142 \mathrm{ft} \\
\text { - Fractures and possible karstic } \\
\text { channels }\end{array}$ \\
\hline Lake Christian West & $\begin{array}{l}\text { Paleozoic sandstone or } \\
\text { alluvial fill (?) }\end{array}$ & 60 to 72 & $\begin{array}{l}\text { - Depth to water }=54 \mathrm{ft} \\
\text { - Weathered bedrock or saturated } \\
\text { alluvium }\end{array}$ \\
\hline School House Mesa & Precambrian (?) & $\begin{array}{l}83 \text { to } 107 \\
(?)\end{array}$ & $\begin{array}{l}\text { - Depth to water }=96 \mathrm{ft} \\
\text { - Fracture in granite (?) }\end{array}$ \\
\hline ITRI MW-1 & $\begin{array}{l}\text { Paleozoic sandstone or } \\
\text { alluvial fill (?) }\end{array}$ & 117 to 125 & $\begin{array}{l}\text { Depth to water }=94 \mathrm{ft} \\
\text { Weathered bedrock or saturated } \\
\text { alluvium }\end{array}$ \\
\hline ITRI MW-2 & $\begin{array}{l}\text { Paleozoic sandstone or } \\
\text { alluvial fill (?) }\end{array}$ & 180 to 189 & $\begin{array}{l}\text { - Depth to water }=144 \mathrm{ft} \\
\text { - Weathered bedrock or saturated } \\
\text { alluvium }\end{array}$ \\
\hline ITRI MW-3 & $\begin{array}{l}\text { Paleozoic sandstone or } \\
\text { alluvial fill (?) }\end{array}$ & 122 to 129 & $\begin{array}{l}\text { - Depth to water }=98 \mathrm{ft} \\
\text { - Weathered bedrock or saturated } \\
\text { alluvium }\end{array}$ \\
\hline ITRI MW-4 & $\begin{array}{l}\text { Paleozoic sandstone or } \\
\text { alluvial fill (?) }\end{array}$ & 102 to 110 & $\begin{array}{l}\text { - Depth to water }=86 \mathrm{ft} \\
\text { - Weathered bedrock or saturated } \\
\text { alluvium }\end{array}$ \\
\hline ITRI MW-5 & $\begin{array}{l}\text { Paleozoic sandstone or } \\
\text { alluvial fill (?) }\end{array}$ & 132 to 141 & $\begin{array}{l}\text { Depth to water }=116 \mathrm{ft} \\
\text { - Weathered bedrock or saturated } \\
\text { alluvium }\end{array}$ \\
\hline ITRI MW-6 & $\begin{array}{l}\text { Paleozoic sandstone or } \\
\text { alluvial fill (?) }\end{array}$ & 118 to 127 & $\begin{array}{l}\text { - Depth to water }=87 \mathrm{ft} \\
\text { - Weathered bedrock or saturated } \\
\text { alluvium }\end{array}$ \\
\hline ITRI MW-7 & $\begin{array}{l}\text { Paleozoic sandstone or } \\
\text { alluvial fill (?) }\end{array}$ & 148 to 157 & $\begin{array}{l}\text { - Depth to water }=109 \mathrm{ft} \\
\text { - Weathered bedrock or saturated } \\
\text { alluvium }\end{array}$ \\
\hline
\end{tabular}


anisotropy in the bedrock is likely. As such, prediction of flow parameters is difficult, and site-specific information is generally required in order to fully assess flow phenomena in the area of interest.

\subsubsection{Santa Fe Group}

A range of hydraulic conductivities has been estimated from various pumping and slug tests in the SNL/KAFB area. Based on the ratio of sand + gravel/silt + clay in the various lithofacies of the Santa Fe Group, Hawley and Haase (1992) estimated the hydraulic conductivity to range over two orders of magnitude, from less than $0.3 \mathrm{ft} /$ day to more than $30 \mathrm{ft} /$ day $(0.09$ to $>9.14 \mathrm{~m} /$ day $)$. This estimate was also based on bedding continuity and bedding connectivity.

Hawley and Haase's (1992) estimates are supported by results obtained from laboratory constant-head and falling-head conductivity tests performed on core samples taken from monitoring well MW-4 at the CWL (Stephens \& Associates 1990a and 1990b). These tests indicate that the hydraulic conductivity can range from $0.01 \mathrm{ft} /$ day to $10.8 \mathrm{ft} /$ day $(0.003$ to $3.29 \mathrm{~m} /$ day).

A pumping test performed on monitoring well MW-2A at the CWL yielded an estimated value of $0.39 \mathrm{ft} /$ day $(0.12 \mathrm{~m} /$ day) for the hydraulic conductivity (SNL/NM 1991b). Slug tests performed on three additional monitoring wells at the CWL provide an estimated range of $0.07 \mathrm{ft} /$ day to $0.09 \mathrm{ft} /$ day $(0.02$ to $0.03 \mathrm{~m} /$ day). Pumping tests performed on both Air Force and City of Albuquerque wells located on KAFB supply a range of values for hydraulic conductivity in subarea 2 . The range of conductivity values in this area was reported as $2 \mathrm{ft} /$ day to $171 \mathrm{ft} /$ day (0.6 to $52.1 \mathrm{~m} /$ day) (SAIC 1985, IT 1985, GMI 1988a-d).

No information was obtained on storativity of the aquifer from either the slug or pumping tests, although the SNL/NM (1991b) report on the CWL indicated that an average value of 0.28 was chosen for this parameter. Generally, storativity, or specific yield, of an unconfined aquifer ranges from 0.01 to 0.30 (Freeze and Cherry 1979).

\subsubsection{Paleozoic/Precambrian Bedrock}

Very little information about the aquifer parameters of the Paleozoic/Precambrian bedrock is available. Although individual boreholes have been drilled at widely scattered locations, hydrologic characterization has been accomplished at only two installations. These installations, the ITRI and the Transportation Safeguards Division (TSD), have wells installed, respectively, in two geologic materials that exhibit distinctly different hydrologic parameters.

Pneumatic slug tests were performed on five monitoring wells at the ITRI location. These wells were probably completed in weathered Paleozoic bedrock (Yeso or Abo Formation). Results from both falling-head and rising-head slug tests were analyzed by two graphical methods: Hvorslev (1951) and Cooper et al. (1967). The results from all four analyses (falling and rising tests for both methods) were then averaged to obtain the mean hydraulic conductivity for the monitoring wells (PRC 1990). This information is presented in Table 4-9. 
Table 4-9

Summary of Slug Test Results at the ITRI (PRC 1990)

\begin{tabular}{|c|c|c|c|c|c|}
\hline \multirow[b]{2}{*}{$\begin{array}{c}\text { WELL } \\
\text { NUMBER }\end{array}$} & \multicolumn{2}{|c|}{$\begin{array}{l}\text { HVORSLEV } \\
\text { METHOD }\end{array}$} & \multicolumn{2}{|c|}{$\begin{array}{r}\text { COOPER } \\
\text { METHOD }\end{array}$} & \multirow[b]{2}{*}{$\begin{array}{c}\mathrm{K} \\
\mathrm{MEAN} \\
\text { (ft/day) }\end{array}$} \\
\hline & $\begin{array}{c}\mathbf{K} \\
\text { [falling] } \\
\text { (ft/day) }\end{array}$ & $\begin{array}{c}\mathbf{K} \\
\text { [rising] } \\
\text { (ft/day) }\end{array}$ & $\begin{array}{c}\mathrm{K} \\
\text { [falling] } \\
\text { (ft/day) }\end{array}$ & $\begin{array}{c}\mathrm{K} \\
\text { [rising] } \\
\text { (ft/day) }\end{array}$ & \\
\hline MW-1 & 6.24 & 7.09 & 6.52 & 5.95 & 6.52 \\
\hline MW-3 (1) & 17.0 & 19.0 & 23.2 & 22.7 & 20.4 \\
\hline MW-3 (2) & 17.3 & 21.0 & 23.0 & 19.0 & 20.1 \\
\hline $\mathrm{MW}-3$ (3) & 17.8 & 21.0 & 24.1 & 19.8 & 20.7 \\
\hline MW-4 & 15.0 & 14.4 & 17.0 & 15.9 & 15.6 \\
\hline MW-5 & 91.6 & 81.1 & 138.3 & 147.1 & 114.5 \\
\hline MW-6 & 38.8 & 35.4 & 68.3 & 63.5 & 51.6 \\
\hline
\end{tabular}

As can be seen from this table, a wide range of hydraulic conductivity was determined by this testing. The mean hydraulic conductivity $(\mathrm{K})$ ranges from a low of $6.52 \mathrm{ft} /$ day to a high of $114.5 \mathrm{ft} /$ day $(1.99$ to $34.9 \mathrm{~m} /$ day). These tests were performed over a very short period of time and as such did not involve a significant volume of rock.

The well installed by the TSD is an exploratory well and was installed in competent bedrock; that is, a combination of granite, quartzite, schist, and other metamorphosed sedimentary rock. A pumping test was performed on TSA-1, from which the transmissivity of the bedrock aquifer was obtained. Transmissivity values were obtained from both the pumping and recovery periods of the test. These values were reported to be $1,992 \mathrm{gpd} / \mathrm{ft}$ and $1,530 \mathrm{gpd} / \mathrm{ft}$, respectively (Geohydrology Associates 1987). In order to relate these values to those obtained in other areas of KAFB, the transmissivities were converted to hydraulic conductivity values using an assumed aquifer thickness of $120 \mathrm{ft}(37 \mathrm{~m})$, the distance between the bottom of the bentonite plug [depth $=180 \mathrm{ft}(55 \mathrm{~m})$ ] and the bottom of the well [depth $=300 \mathrm{ft}(91 \mathrm{~m})]$. Given this information, the hydraulic conductivity calculated from the drawdown test is approximately $2.22 \mathrm{ft} /$ day $(0.68 \mathrm{~m} /$ day $)$, whereas the conductivity calculated from the recovery test is approximately $1.70 \mathrm{ft} /$ day $(0.52 \mathrm{~m} /$ day $)$.

\subsubsection{Flow Direction}

The rate and direction of groundwater flow through a porous and fractured media is controlled by the hydraulic gradient and the distribution of the hydraulic conductivity. 
The hydraulic gradient associated with an aquifer is determined from measurements of the static water level in wells that are screened within the aquifer. The direction of lateral groundwater flow is then assumed to be perpendicular to the potentiometric contour lines drawn from the static water levels.

Water-level data from monitoring wells in the SNL/NM area and other appropriate KAFB wells were used to generate the SNL/KAFB area potentiometric map (Figure 4-9). The KAFB wells are screened over large intervals, usually starting at the water table and extending several hundred feet into the saturated Santa Fe Group sediments. The SNL/NM monitoring wells typically have $20-\mathrm{ft}(6-\mathrm{m})$ screens placed at the water table (SNL/NM 1992b). The representative potentiometric surface map was drawn with the assumption that the vertical gradient can be ignored. However, this assumption might not be appropriate in some areas of the base.

Based on regional groundwater flow trends (see Figure 4-11), one would expect the general trend of groundwater flow in the SNL/KAFB area to be westward toward the Rio Grande. However, site-specific hydraulic gradients can be influenced by groundwater pumpage. This affect is illustrated in Figure 4-9. According to the water-level data, although the apparent direction of groundwater flow in the SNL/KAFB area is generally to the west, the apparent direction of groundwater flow in the northwest corner of the base is to the northwest, due to pumping of production wells for both KAFB and the City of Albuquerque. This pumping has created a cone of depression in the area, causing the local hydraulic gradient to counter the regional trend. The exact extent of the cone of depression in this region is not yet known, but is currently under investigation (SNL/NM 1992b).

The potentiometric surface at TA-III is shown in Figure 4-19 and generally agrees with the regional groundwater flow direction. However, on a local scale the hydraulic gradient is relatively flat, which can lead to questions concerning flow directions. This flat gradient leads to uncertainty in locating up-gradient and down-gradient monitoring wells at individual ER sites. Therefore, ER sites are forced to rely on the SNL/KAFB site-wide groundwater flow directions for the placement of monitoring wells.

\subsubsection{Horizontal Gradients}

The horizontal hydraulic gradient is variable across the SNL/KAFB area (Figure 4-9). In the vicinity of TA-III, the horizontal gradient is approximately 0.012 . The gradient increases almost an order of magnitude as one nears the fault complex (0.09). East of the fault complex, the gradient decreases to approximately 0.04 . However, water-level data east of the fault complex is limited.

\subsubsection{Vertical Gradients}

The magnitude and direction of vertical hydraulic gradients within the Santa Fe Group is an issue of considerable uncertainty. The potential for vertical hydraulic gradients within the Santa Fe Group has been acknowledged in the literature, but few data are available to prove or disprove their existence. For the sake of simplicity, existing groundwater models of the 


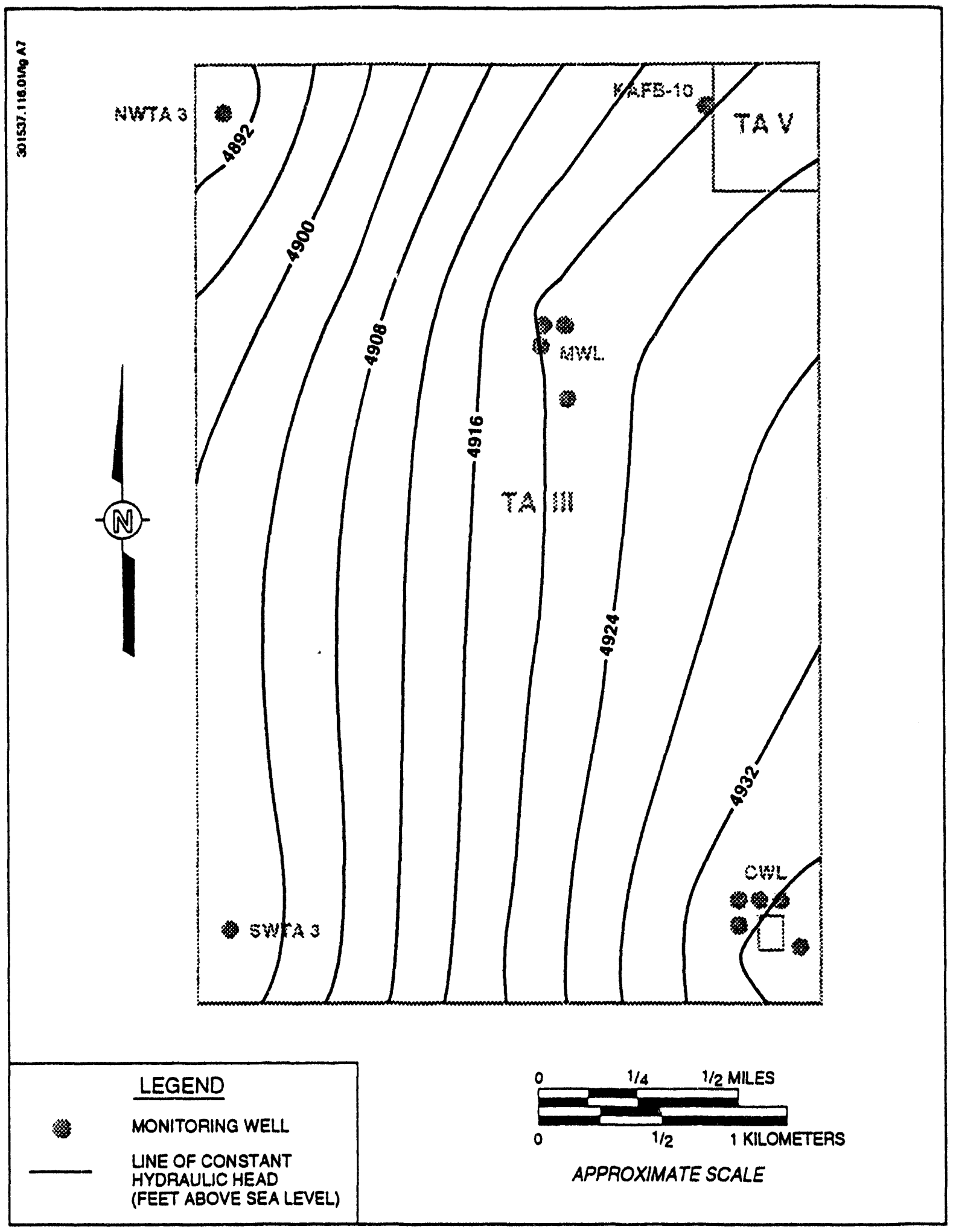

Figure 4-19. Technical Area III Potentiometric Surface Map, May 1992 (5-ft contour interval) 
SNL/KAFB vicinity generally ignore the potential for vertical hydraulic gradients by assuming that the Santa $\mathrm{Fe}$ Group is a single aquifer with horizontal hydraulic gradients only (Kernodle and Scott 1986). During drilling of borehole SFR-1, multiple water-bearing zones with apparently different heads were encountered. Such a discovery presents a potential challenge to the conventional assumption about groundwater gradients central to all past modeling efforts.

To assess the potential for vertical hydraulic head variation at this location, SFR-1 was completed as a dual monitoring well. Figure 4-20 is a schematic diagram of this completion, showing the difference in static water levels between the two completion intervals. The vertical gradient between these two completion intervals is approximately 0.28 downward. The meaning of this vertical gradient depends on the actual field conditions at this location. For example, if the upper completion interval is a perched zone, the vertical gradient is between this local perched aquifer and the underlying saturated zone aquifer. Alternatively, if the upper completion interval is within the unconfined saturated zone aquifer, the vertical gradient would be between this water-table aquifer and an underlying confined aquifer. In addition to these two scenarios, it is possible that multiple confined and/or semiconfined aquifers with different hydraulic heads exist deeper in the Santa Fe Group sediments. In that each of these types of vertical gradients has a different meaning relative to groundwater contaminant transport, it is important that the actual field condition for all monitoring well completion intervals (i.e., perched, water-table, and confined) be known.

\subsubsection{Summary: Uncertainties and Plans}

The overall goal of characterizing saturated zone hydrology is to reduce the uncertainty on the rate and direction of groundwater flow at SNL/KAFB. As indicated in this section, significant uncertainty exists in our understanding of both the basic hydrogeologic framework of the area and the quantification of critical hydrologic parameters. The reduction of uncertainty will be accomplished within the context of an objective quantitative approach that will seek to optimize the application of field characterization resources (see Section 2.0). This objective approach will be tied to assessment of risks to the environment and human health posed by the different SNL/KAFB ER sites and will focus on reducing uncertainty in critical parameters in the vicinity of the "riskiest sites."

The overall site-wide saturated zone characterization strategy will be driven by critical parameters and identified performance measures, and will be updated based on quantitative criteria related to the reduction of uncertainty. In addition, this strategy will reflect close coordination with all ER Program task leaders. This coordination will be accomplished to identify ER Program needs relative to site-specific Work Plans, Closure Plans, RFIs, and Corrective Measures Studies. Elements involved in the saturated zone characterization will include developing subarea flow models (planning and reporting), applying the quantitative approach to identify critical data gaps (numerical model application), and acquiring parameters to fill these gaps (drilling and testing). These elements taken together are intended to establish a strong, site-wide hydrogeologic understanding that will be used to support ER Program characterization and remediation projects. 


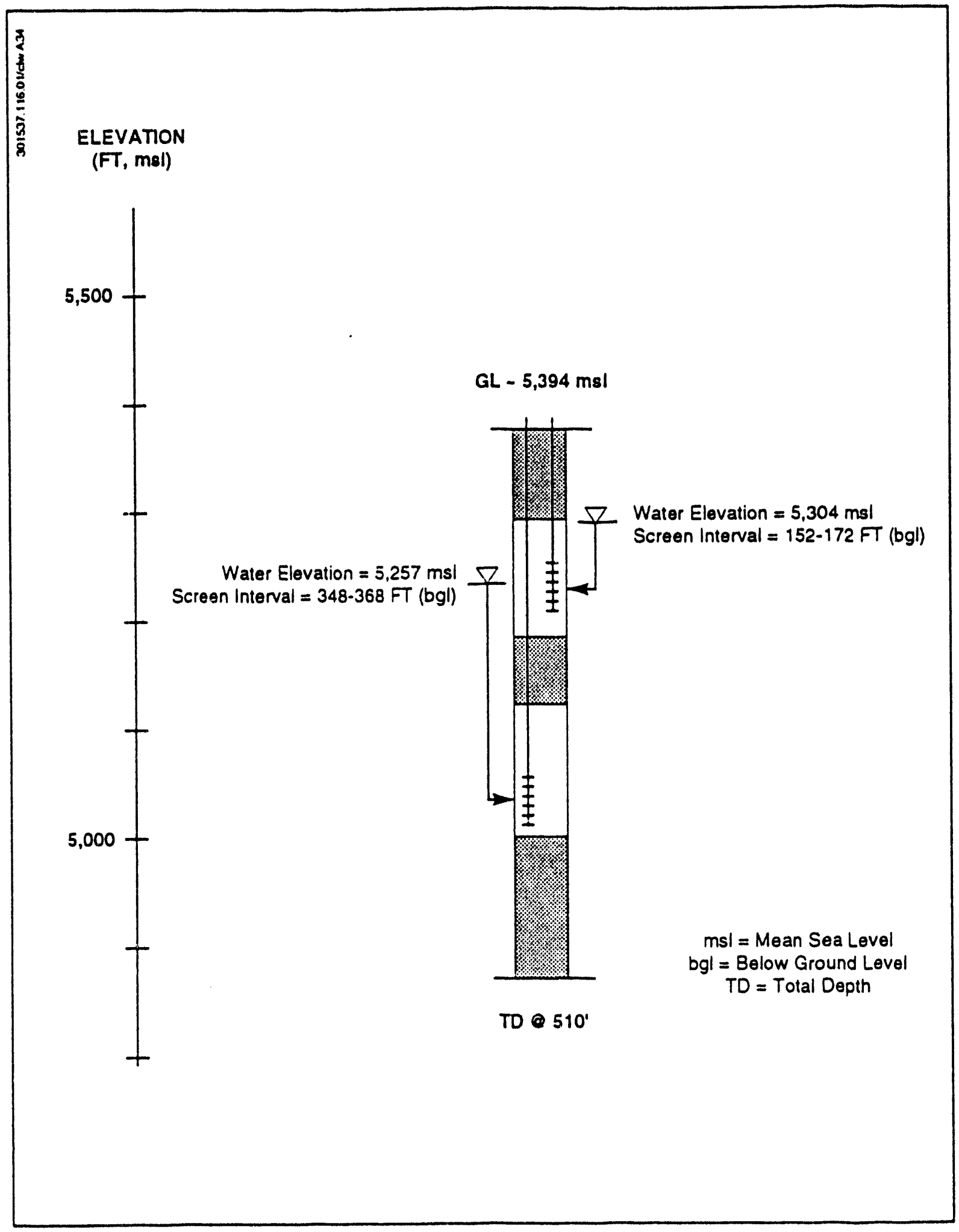

Figure 4-20. Completion Schematic Showing Water Levels for the SFR-1 Monitoring Intervals 


\subsection{Groundwater Chemistry}

Collection and analysis of groundwater chemistry data on the SNL/KAFB site are designed to address several objectives within the ER program:

- Definition of naturally occurring background concentrations of constituents of interest in the groundwater.

- Determination of the ambient chemical conditions in groundwater that influence mobilization and transport of potential contaminants.

- Application of groundwater chemistry to define groundwater flow regimes and flowpaths, and recharge and discharge areas.

Data sources for groundwater quality are currently being developed by site-specific sampling programs and a site-wide groundwater monitoring program.

\subsubsection{Regional Groundwater Chemistry}

Regional groundwater chemistry trends of the Albuquerque Basin have been studied by Anderholm (1988), and the groundwater chemistry on the east slope of the Sandia, Manzanita, and Manzano Mountains by Titus (1980). Except where noted, the discussion in this section is based on these references.

The Albuquerque Basin receives water from two principal sources: the through-flowing Rio Grande and recharge from the basin margins. Groundwater also enters the basin from the Santa Domingo Basin and possibly the San Juan Basin to the north, and exits into the Socorro Basin to the south. While in the basin, these waters mix with waters draining off surrounding highlands.

A variety of factors led to the development of the diverse groundwater chemistries found in the Albuquerque Basin. The eastern margin of the basin consists of the crystalline and metasedimentary rocks of the Sandia-Manzanita-Manzano Mountains. Groundwaters derived form this area are predominantly calcium bicarbonate waters. Along the southeastern margin of the basin, Permian-age, gypsum-bearing sediments occur on a structural bench extending westward from the Sandia-Manzanita-Manzano Mountain front. Groundwaters derived from this area are predominantly calcium sulfate waters. The western margin of the Albuquerque Basin contains Cretaceous-age argillaceous sediments that are covered by a veneer of Tertiary to Recent alluvium. Groundwaters derived from this area are sodium sulfate waters that formed in response to ion exchange of calcium for sodium by the abundant clays, gypsum dissolution, and pyrite oxidation. At the north end of the Albuquerque Basin, near the Jemez Volcanic Massif, groundwaters entering the basin are characterized by high chloride and silica concentrations, which are due to the influence of an active hydrothermal system. Basin-wide, such diversity of hydrogeochemistry results in complex spatial relationships among groundwater types. 
Yapp (1985) examined the variation in the ${ }^{2} \mathrm{H} /{ }^{1} \mathrm{H}$ ratio of hydrogen contained in meteoric waters of the Albuquerque area. Samples of precipitation, surface water from the Rio Grande, and groundwater from well waters and springs were analyzed for differences in isotopic composition. The data exhibit a wide range of ${ }^{2} \mathrm{H} /{ }^{1} \mathrm{H}$ ratios from within a source group, and among groups. On the basis of the discernible isotopic signatures of the water sources, Yapp (1985) reached the following conclusions: (1) based on the principal components of groundwater recharge, the Rio Grande and the Sandia and Manzano Mountains have distinctive ${ }^{2} \mathrm{H} /{ }^{1} \mathrm{H}$ ratios, (2) the isotopic heterogeneity of the groundwater suggests that there are distinct domains of groundwater within the Santa Fe Formation in the Albuquerque vicinity, (3) these domains retain their isotopic identity over fairly long time scales, and (4) the isotopic signatures of these groundwater domains are an apparent reflection of the dominant source of local recharge. The isotopic data confirm that the Rio Grande and run-off from the Sandia and Manzano Mountains are the principal sources of modern recharge of the upper portion of the Santa Fe Group aquifer in the Albuquerque and SNL/KAFB areas.

\subsubsection{SNL/KAFB Groundwater Chemistry}

Riddle and Grant (1981) sampled groundwaters from water supply wells and springs on $\mathrm{SNL} / \mathrm{KAFB}$. The wells sampled typically penetrate 1,000 to $1,100 \mathrm{ft}(305$ to $335 \mathrm{~m}$ ) into the Santa Fe Group sediments. The springs sampled were located in Tijeras Arroyo, the mouth of Coyote Canyon, and Hubbell Spring on the Isleta Pueblo Indian Reservation. Results are tabulated in Table 4-10.

Table 4-10

Summary of Water Chemistry for Selected Wells and Springs at KAFB (Concentrations are in ppm; Riddle and Grant 1981)

\begin{tabular}{|c|c|c|c|c|}
\hline & $\begin{array}{l}\text { COYOTE } \\
\text { SPRING }\end{array}$ & $\begin{array}{l}\text { TIJERAS } \\
\text { SPRING } \\
\end{array}$ & $\begin{array}{l}\text { HUBBELL } \\
\text { SPRING } \\
\end{array}$ & $\begin{array}{c}\text { WATER SUPPLY } \\
\text { WELLS (21) } \\
\end{array}$ \\
\hline $\mathrm{pH}$ & 6.0 & $5.0-6.0$ & 6.0 & $5.0-8.5$ \\
\hline $\mathrm{Ca}$ & $184-260$ & $79-114$ & 100 & $19-180$ \\
\hline $\mathrm{Mg}$ & $39-56$ & $25-30$ & 18 & $0.9-40$ \\
\hline $\mathrm{Na}$ & $179-329$ & $39-53$ & 18 & $17-51$ \\
\hline $\mathrm{K}$ & $11-26$ & $1.3-4.8$ & 1.4 & $0.7-4.7$ \\
\hline $\mathrm{HCO}_{3}$ & $730-1133$ & $228-273$ & 288 & $116-726$ \\
\hline $\mathrm{SO}_{4}$ & N.D. & N.D. & N.D. & $18-120$ \\
\hline $\mathrm{Cl}$ & $17-478$ & $96-220$ & 46 & $3.2-95$ \\
\hline $\mathrm{F}$ & N.D. & N.D. & N.D. & $0.2-1.8$ \\
\hline $\mathrm{SiO}_{2}$ & $17-18$ & $19-27$ & 17 & $10-43$ \\
\hline
\end{tabular}


In general, the wells and the springs in Tijeras Arroyo reflect water compositions derived from run-off from the Sandia and Manzanita Mountains. They are calcium-bicarbonate-rich waters with lesser amounts of chloride, sulfate, and sodium. The water samples from Coyote Springs differ from samples obtained from other wells and springs in that they have significantly higher total dissolved solids concentration. These samples also had high boron [0.97-0.41 parts per million (ppm)] concentrations when compared to other well and spring samples $(0.006-0.05 \mathrm{ppm})$.

Goodrich and Stein (1991) analyzed groundwater quality data to determine, among other things, whether there was any pattern to the variability of well and spring water compositions on the SNL/KAFB site south of Tijeras Arroyo. In all, twelve wells lying west of the Hubbell Spring-Sandia Fault trend were repeatedly analyzed. These results were compared with data from four wells and two springs east of the fault trend (Table 4-11).

Table 4-11

April 1991 SNL/KAFB Groundwater Sampling Results (Concentrations in ppm; from Goodrich and Stein 1991)

\begin{tabular}{|l|c|c|c|}
\hline & $\begin{array}{c}\text { WELLS (12) } \\
\text { WEST OF FAULT }\end{array}$ & $\begin{array}{c}\text { WELLS (2) } \\
\text { EAST OF FAULT }\end{array}$ & $\begin{array}{c}\text { SPRINGS (3) }^{2} \\
\text { EAST OF FAULT }\end{array}$ \\
\hline $\mathrm{pH}$ & $7.1-8.5$ & $6.5,7.0$ & $6.6,6.4,7.8$ \\
\hline $\mathrm{Ca}$ & $23-67$ & 324,137 & $130,80,84$ \\
\hline $\mathrm{Mg}$ & $3.8-17$ & 77,24 & $41,51,14$ \\
\hline $\mathrm{Na}$ & $18-146$ & 312,77 & $107,119,14$ \\
\hline $\mathrm{K}$ & $1.3-10$ & $24,6.7$ & $8.2,16,1.3$ \\
\hline $\mathrm{HCO}_{3}$ & $24-288$ & 1995,434 & $--, 1232,293$ \\
\hline $\mathrm{SO}_{4}$ & $23-125$ & 73,50 & $83,120,75$ \\
\hline $\mathrm{Cl}$ & $5-140$ & 181,117 & $198,441,18$ \\
\hline $\mathrm{F}$ & $0.15-1.4$ & $0.8,0.6$ & $0.9,1.3,0.2$ \\
\hline $\mathrm{NO}{ }_{3}$ & $0.3-142$ & $1.6,17$ & $1.9,3.6,6.0$ \\
\hline $\mathrm{Br}$ & $>0.2-1.2$ & $1.8,0.8$ & $1.0,2.4,0.4$ \\
\hline
\end{tabular}

1. EOD Hill, School House Wells.

2. "G," Coyote, Sol se Mete Springs.

Inspection of the data presented in Table 4-11 suggests the groundwaters east and west of the Sandia/Hubbell Fault line are chemically different. To evaluate and quantify such differences, Goodrich and Stein (1991) conducted statistical analysis of the data. For two of 
the quarterly sampling periods, the analysis indicated that there was no statistically significant distinction between the potassium, sodium, fluorine, nitrate, and sulfate concentrations. However, $\mathrm{pH}$, magnesium, calcium, chlorine, bromine, and bicarbonate all proved to have statistically different populations on opposite sides of the fault line.

Groundwater chemistry data for major ion concentrations for three quarterly site-wide groundwater sampling periods in 1991 are illustrated in Figures 4-21, 4-22, and 4-23. Additional data on groundwater quality are reported in the SNL/NM Annual Groundwater Monitoring Reports (SNL/NM 1992b, 1993). Groundwater quality data for wells and springs in the SNL/KAFB area are currently being assembled into an electronic database, which will greatly simplify data reporting and analyses for subsequent applications. 


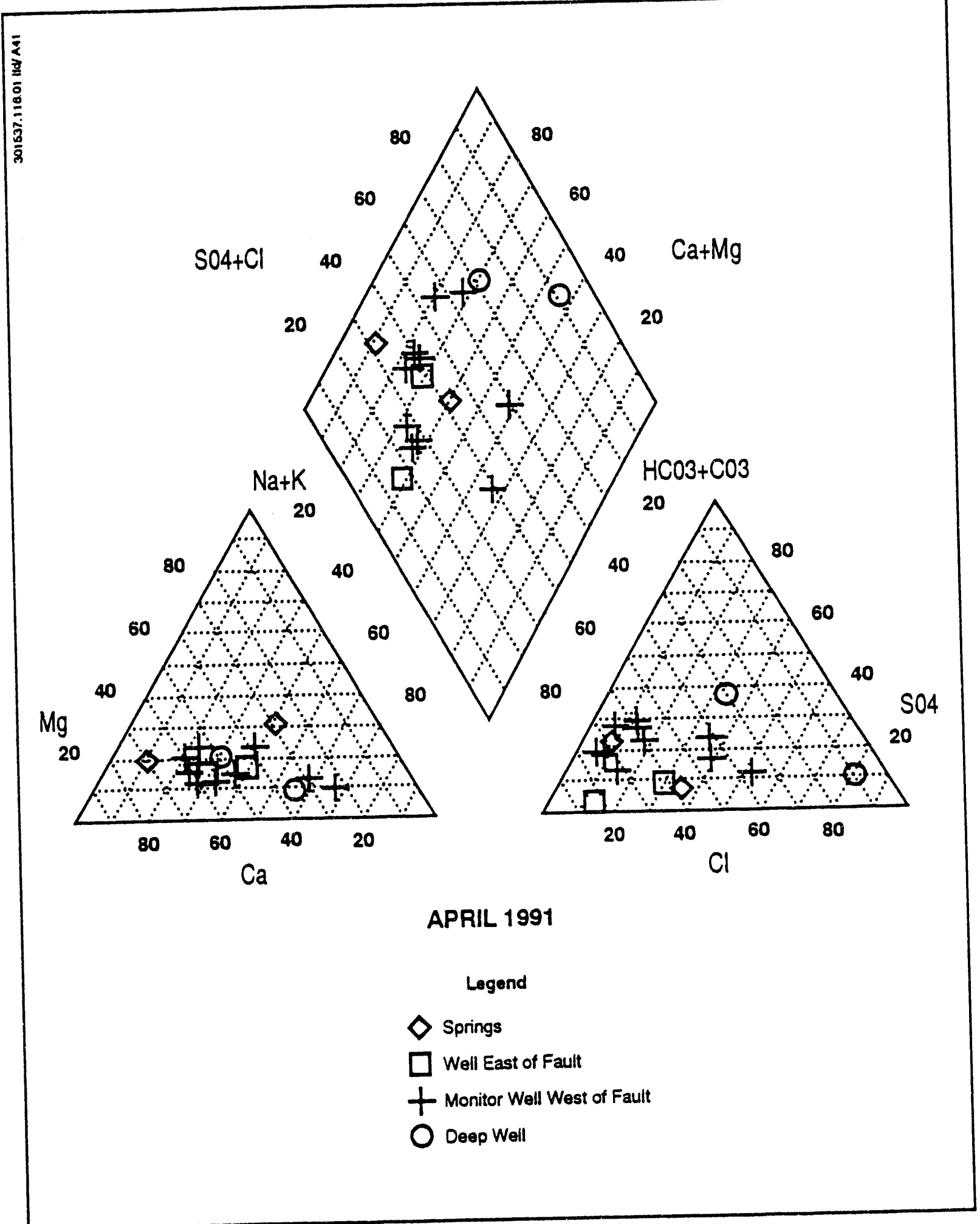

Figure 4-21. Piper Diagram for the April 1991 Sampling Period 


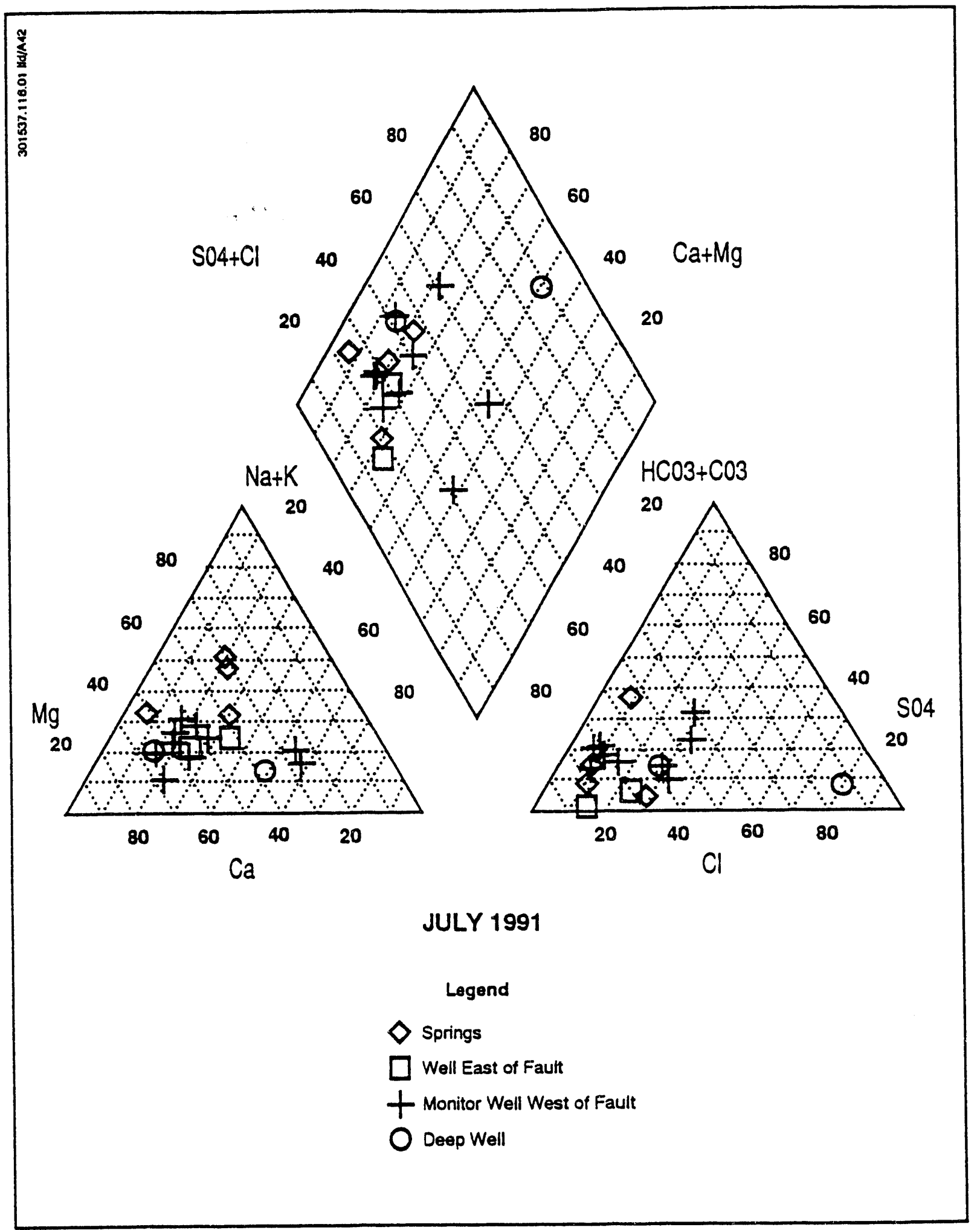

Figure 4-22. Piper Diagram for the July 1991 Sampling Period 


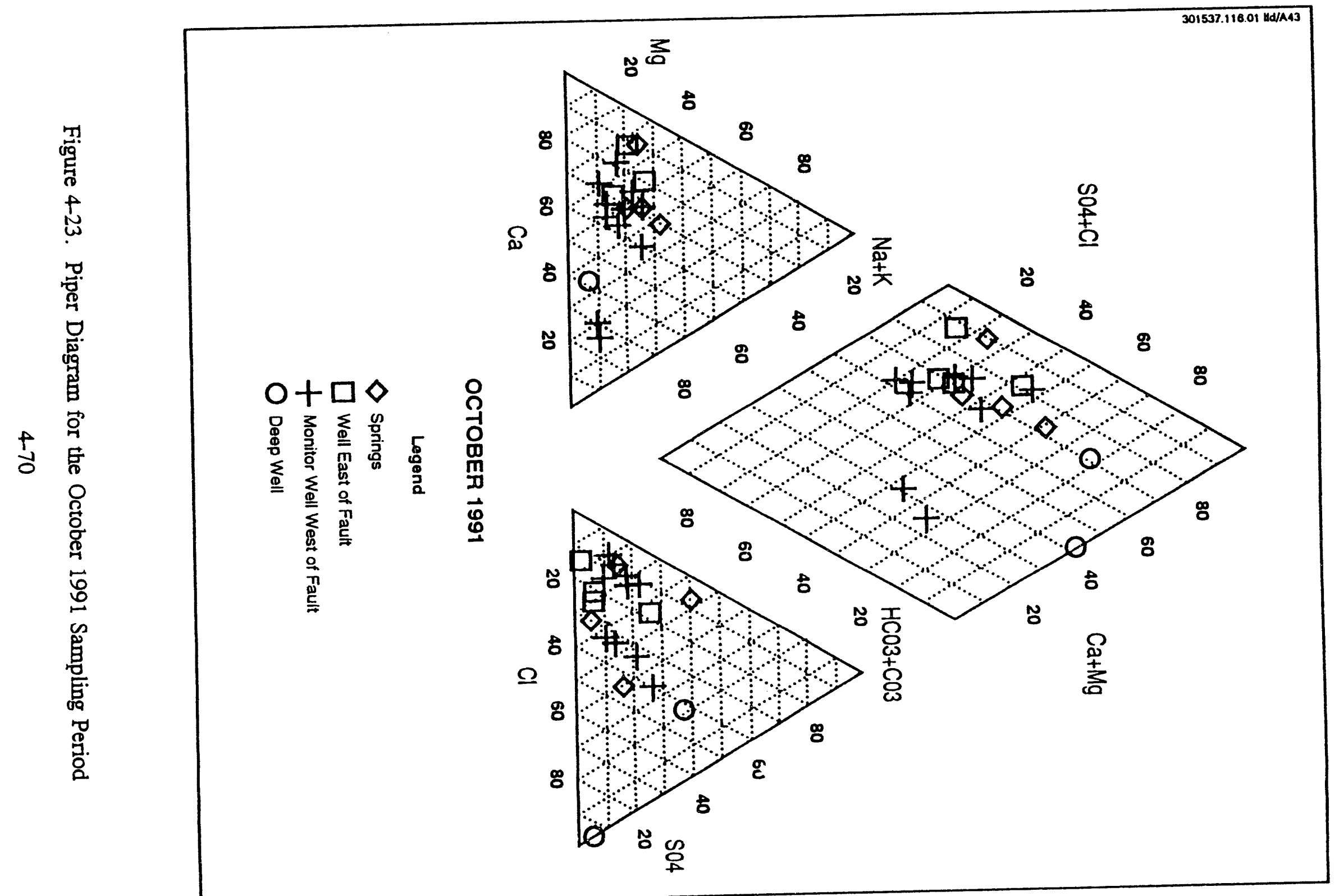




\subsection{References}

Anderholm, S. K., 1987. Reconnaissance of Hydrology, Land Use, Ground-Water Chemistry, and Effects of Land Use on Ground-Water Chemistry in the AlbuquerqueBelen Basin. New Mexico, U.S. Geological Survey Water-Resources Investigations Report 86-4174, 37 pp.

Anderholm, S. K., 1988. Ground-Water Geochemistry of the Albuquerque-Belen Basin. Central New Mexico, U.S. Geological Survey Water-Resources Investigations Report $86-4094,110 \mathrm{pp}$.

Anderholm, S. K., 1992. Personal communication, USGS Water Resource Division, Albuquerque District Office, Albuquerque, NM.

Ardito, C., T. Duval, and S. Young, 1993. Soil Gas Sampling at Sandia National Laboratories Chemical Waste Landfill, SAND93-7034, in preparation, Sandia National Laboratories, Albuquerque, NM.

Birch, F. F., 1980. Geophysical Evaluation of Basin Hydrologic Characteristics in the Central Rio Grande, Part I: Gravity Models of the Albuquerque-Belen Basin, unpublished report prepared for the U.S. Geological Survey, Contract No. 14-08-0000117879.

Bjorklund, L. J., and B. W. Maxwell, 1961. Availability of Ground Water in the Albuquerque Area, Bernalillo and Sandoval Counties, New Mexico, New Mexico State Engineer Technical Report 21, $117 \mathrm{pp}$.

Bohannan-Huston, Inc., 1992. Storm Drain Master Plan for Areas I, II, and IV, Sandia National Laboratories, Albuquerque, NM.

Bonzon, L. L., B. S. Estes, J. S. Philloin, and J. A. Reuscher, 1974. Sandia Pulsed Reactor III (SPR III) Safety Analysis Report, SLA-74-0349, Sandia National Laboratories, Albuquerque, NM.

Bovay Engineers, Inc., 1981. Tijeras Arroyo Drainage Management Plan, Albuquerque Metropolitan Arroyo Flood Control Authority, Albuquerque, NM.

Cavin, W. J., J. R. Connolly, and L. A. Woodward, 1982. Precambrian Stratigraphy of the Manzanita and North Manzano Mountains, New Mexico, 33d Field Conference Guidebook, Albuquerque Country II, New Mexico Geological Society, pp. 191-196.

Cislerova, M., T. Vogel, and J. Simunek, 1990. The Infiltration-Outflow Experiment Used to Detect Flow Deviations, in Field-Scale Water and Solute Flux in Soils, Bikhauser Verlag, Basel, pp. 109-128. 
COE (U.S. Army Corps of Engineers), 1979. Special Flood Hazard Information. Tijeras Arroyo and Arroyo del Coyote, Kirtland AFB, New Mexico, U.S. Army Corps of Engineers, Albuquerque District, Albuquerque, NM.

Conrad, S. H., A. M. Parsons, and E. D. Mattson, 1992. The Sniffing Dog Approach to Defining Plumes Emanating from DNAPLs in the Subsurface, extended abstract presented at Subsurface Restoration Conference, June 21-24, 1992, Dallas, TX.

Cooper, H. H., Jr., J. D. Bredehoeft, and I. S. Papadopoulos, 1967. Response of a FiniteDiameter Well to an Instantaneous Charge of Water, Water Resources Research, vol. 3, no. 1 , pp. 263-269.

Dane, J. H., and F. J. Moltz, 1991. Physical Measurements in Subsurface Hydrology, Reviews of Geophysics, Supplement, U.S. National Report to International Union of Geodesy and Geophysics 1987-1990, pp. 270-279.

DOE (U.S. Department of Energy), 1988. RCRA Ground Water Monitoring Plan, Sandia National Laboratories. Chemical Waste Landfill, draft report prepared by Department of Energy Albuquerque Operations Office, Environment and Health Division, ER Program Project Group, Albuquerque, NM.

E\&E (Ecology and Environment), 1989. Groundwater Monitoring Wells Installation: Mixed Waste Landfill, contractor report prepared for the Environmental Restoration Program, Sandia National Laboratories, Albuquerque, NM.

E\&E (Ecology and Environment), 1990. Phase I Investigation Report for the Mixed Waste Landfill, unpublished report prepared for Environmental Restoration Program, Sandia National Laboratories, Albuquerque, NM.

Everett, L. G., E. W. Hoylman, L. G. Wilson, and L. G. McMillion, 1984. Constraints and Categories of Vadose Zone Monitoring Devices, Ground Water Monitoring Review, vol. 4 , no. 1 , pp. 26-30.

Freeze, R. A., and J. A. Cherry, 1979. Groundwater, Englewood Cliffs, NJ: Prentice-Hall.

Galusha, T., and J. C. Blick, 1971. Stratigraphy of the Santa Fe Group, New Mexico, American Museum of Natural History Bulletin, `ol. 144, article 1, 125 pp.

Gee, G. W., and D. Hillel, 1988. Groundwater Recharge in Arid Regions: Review and Critique of Estimation Methods, Hydrological Processes, vol. 2, pp. 255-266.

Gee, G. W., C. T. Kincaid, R. J. Lenhard, and C. S. Simmons, 1991. Recent St.dies of Flow and Transport in the Vadose Zone, Reviews of Geophysics, Supplement, U.S. National Report to International Union of Geodesy and Geophysics 1987-1990, pp. 227-239. 
Geohydrology Associates, Inc., 1987. Drilling Su. nary of the TSA Exploratory Well No. 1, unpublished report to U.S. Department of Energy, December 1987.

Glass, R. J., T. S. Steenhuis, and J.-Y. Parlange, 1988. Wetting Front Instability as a Rapid and Far-Reaching Hydrologic Process in the Vadose Zone, J. Contamin. Hydrol., 3, pp. 207-226.

Glass, R. J., R. Holt, J. Brainard, K. Martin, D. Baird, D. Garrett, and R. Morris, 1993. Vadose Zone Characterization: A Preliminary Study, SAND93-0948, in preparation, Sandia National Laboratories, Albuquerque, NM.

GMI (Groundwater Management Incorporated), 1988a. Pumping Test Data Analysis: Burton Well Field, City of Albuquerque, New Mexico, unpublished report prepared for Black \& Veatch Engineers, Aurora, CO, February 2, 1988.

GMI (Groundwater Management Incorporated), 1988b. Pumping Test Data Analysis: Miles Road Well Field, City of Albuquerque, New Mexico, unpublished report prepared for Black \& Veatch Engineers, Aurora, CO, February 2, 1988.

GMI (Groundwater Management Incorporated), 1988c. Pumping Test Data Analysis: Ridgecrest Well Field, City of Albuquerque, New Mexico, unpublished report prepared for Black \& Veatch Engineers, Aurora, CO, February 2, 1988.

GMI (Groundwater Management Incorporated), 1988d. Pumping Test Data Analysis: Yale Well Field, City of Albuquerque, New Mexico, unpublished report prepared for Black \& Veatch Engineers, Aurora, CO, February 12, 1988.

Goodrich, D., 1992. Personal communication, USDA-ARS Southwest Region Watershed Experiment Station, Tucson, AZ.

Goodrich, M. T., and C. L. Stein, 1991. A Regional Hydrogeochemical Investigation of the Albuquerque Basin, New Mexico (abstract), EOS, vol. 72, no. 44, p. 178.

Grant, P. R. 1982. Geothermal Potential in the Albuquerque Area, New Mexico, 33d Field Conference Guidebook: Albuquerque Country II, New Mexico Geological Society, pp. 325-331.

Hawley, J. W., and C. S. Haase, 1992. Hydrogeologic Framework of the Northern Albuquerque Basin, 1992, New Mexico Bureau of Mines and Mineral Resources OpenFile Report 387.

Hearne, G. A., and J. D. Dewey, 1988. Hydrologic Analysis of the Rio Grande Basin North of Embudo, New Mexico, Colorado and New Mexico, U.S. Geological Survey Water-Resources Investigations Report 86-4113, 244 pp.

Hvorslev, M. J., 1951. Time Log and Soil Permeability in Groundwater Observations, U.S. Army Corp of Engineers, Waterway Exp. Sta. Bull. 36, Vicksburg, M5. 
INTERA, Inc., 1991. Preliminary Groundwater Modeling Calculations in the Vicinity of Technical Area II, unpublished Report for the Environmental Restoration Program, November 4, 1991, Sandia National Laboratories, Albuquerque, NM.

IT (International Technology Corporation), 1985. RCRA Interim Status Groundwater Monitoring Plan. Chemical Waste Landfill, prepared for Sandia National Laboratories, Albuquerque, NM.

IT (International Technology Corporation), 1991. Unpublished preliminary report on interpretation of surface gravity survey data for fault delineation, prepared for the Environmental Restoration Division, Sandia National Laboratories, Albuquerque, NM.

IT (International Technology Corporation) and Consensus Planning, Inc., 1992. Sandia National Laboratories. Albuquerque Environmental Baseline Update, report prepared for Sandia National Laboratories, Albuquerque, NM.

IT (International Technology Corporation), 1992. Surface Gravity Survey for Fault Delineation and Hydrogeologic Characterization, unpublished revised report on interpretation of surface gravity survey data for the Environmental Restoration Division, October 1992, Sandia National Laboratories, Albuquerque, NM.

Kelley, V. C., 1977. Geology of the Albuquerque Basin, New Mexico, Memoir 33, New Mexico Bureau of Mines and Mineral Resources.

Kelly, T. E., 1982. History of Water Use in the Greater Albuquerque Area, 33d Field Conference Guidebook: Albuquerque Country II, New Mexico Geological Society, pp. 351-355.

Kelley, V. C., and S. A. Northrop, 1975. Geology of the Sandia Mountains and Vicinity, New Mexico, Memoir 29, New Mexico Bureau of Mines and Mineral Resources.

Kernodle, J. M., 1992. Summary of U.S. Geological Survey Ground-Water Flow Models of Basin-Fill Aquifers in the Southwestern Alluvial Basins Region, Colorado, New Mexico, and Texas, U.S. Geological Survey Open-File Report 90-361, 81 pp.

Kernodle, J. M., and W. B. Scott, 1986. Three-Dimensional Model Simulation of SteadyState Ground-Water Flow in the Albuquerque-Belen Basin. New Mexico, U.S. Geological Survey, Water Resources Investigation Report 84-4353.

Kernodle, J. M., R. S. Miller, and W. B. Scott, 1987. Three-Dimensional Model Simulation of Transient Ground-Water Flow in the Albuquerque-Belen Basin, New Mexico, U.S. Geological Survey, Water Resources Investigation Report 86-4194. 
Kung, K., and J. Samuel, 1988. Ground Truth About Water Flow Pattern in a Sandy Soil and Its Influences on Solute Transport Modeling, in Proceedings of the International Conference on Validation of Flow and Transport Models for the Unsaturated Zone, May 23-26, Ruidoso, NM. Research Report 88-SS-04, Dept. of Agronomy, New Mexico State University, Las Cruces, NM, pp. 224-230.

Leedshill-Herkenhoff, Inc., 1987. Tijeras Arroyo Drainage Management Plan, Phase I: City of Albuquerque, Albuquerque, NM.

Lozinsky, R. P., 1988. Stratigraphy, Sedimentology, and Sand Petrology of the Santa Fe Group and Pre-Santa Fe Tertiary Deposits in the Albuquerque Basin. Central New Mexico, Ph.D. thesis, New Mexico Institute of Mining and Technology, Socorro, NM.

McCann, M. W., and Boissonnade, A. C., 1988. Natural Phenomena Hazards Modeling Project: Preliminary Flood Hazard Estimates for Screening Department of Energy Sites, Albuquerque Operations Office, Lawrence Livermore National Laboratory, University of California, Livermore, CA.

McCord, J. T., and D. B. Stephens, 1987. Laterial Moisture Movement on Sandy Hillslope in the Apparent Absence of an Impending Layer, Hydrologic Processes, 1(3), pp. 225-238.

McCord, J. T., D. Crowson, R. Holt, J. Piper, and E. K. Webb, 1993. Detailed Mapping and Preliminary Geostatistical Analysis of Alluvial Fan Deposits Exposed in Six Miles of Trench, SAND93-0680, in preparation, Sandia National Laboratories, Albuquerque, NM.

McTigue, D. L. and C. Stein, 1990. "Retention Curves and Saturated Hydraulic Conductivities of Area III Alluvium," Sandia National Laboratories internal memorandum January 16, 1990, to Distribution from McTigue, Division 1511, and Stein, Division 6233, $21 \mathrm{pp}$.

Myers, D. A. and E. J. McKay, 1970. Geologic Map of the Mount Washington Quadrangle, Bernalillo and Valencia Counties, New Mexico, Geological Quadrangle Map GQ-886, U.S. Geological Survey.

Myers, D. A., and E. J. McKay, 1976. Geologic Map of the North End of the Manzano Mountains, Tijeras and Sedillo Quadrangles, Bernalillo County, New Mexico, Miscellaneous Investigations Map I-968, U.S. Geological Survey.

Neel, D., and J. P. McCord, 1993. Summary of May-November 1992 Field Operations South Fence Road Project, unpublished report prepared for Sandia Environmental Restoration Division, February 1993.

NOAA (National Oceanographic and Atmospheric Administration), 1990. Local Climatological Data, Annual Summary with Comparative Data, Albuquerque, NM. 
NOAA (National Oceanographic and Atmospheric Administration), 1993. Personal communication, National Weather Service, Albuquerque, NM.

Olsen, O., M. H. Hall, and M. H. Plagge, 1970. Wind Data for the Albuquerque Area, SC-M-70-144, Sandia National Laboratories, Albuquerque, NM.

Parsons, A. M., R. J. Glass, and J. T. McCord, 1993. Vadose Characterization Task Plan for the Site-Wide Hydrogeologic Characterization Project, SWHC/TP4.001, prepared for the Environmental Restoration Department, Sandia National Laboratories, Albuquerque, NM.

Persaud, N., and P. J. Wierenga, 1982. Solute Interactions and Transport in Soils from Waste Disposal Sites at Sandia Laboratories, prepared by the Department of Agronomy, New Mexico State University, Las Cruces, NM, 237 pp.

Phelan, J., 1989. Chromium Migration from Pit 2A of the Chemical Waste Landfill, unpublished report prepared by Environmental Impact and Restoration Division, Sandia National Laboratories, Albuquerque, NM.

Phillips, F. M., J. L. Mattick, and T. A. Duval, 1988. Chlorine-36 and Tritium from Nuclear Weapons Fallout as Tracers for Long-Term Liquid and Vapor Movement in Desert Soils, Water Resources Research, 24(11), pp. 1877-1891.

PRC Environmental Management, Inc., 1990. ITRI Lagoon Hydrogeological Study, unpublished report prepared for the Lovelace Inhalation Toxicology Research Institute, September 1990.

Reiche, P., 1949. Geology of the Manzanita and North Manzano Mountains, New Mexico, Geological Society of America Bulletin, vol. 60, Geological Society of America, pp. 1183-1212.

Riddle, L., and P. R. Grant, 1981. Geothermal Studies at Kirtland Air Force Base, Albuquerque, New Mexico, SAND81-0852, May 1981, Sandia National Laboratories, Albuquerque, NM.

SAIC (Science Applications International Corporation), 1985. Installation Restoration Program Phase II: Confirmation/ Quantification Stage 1 for Kirtland Air Force Base, Albuquerque, New Mexico, unpublished report for the U.S. Air Force, March 1985.

SNL/NM (Sandia National Laboratories, New Mexico), 1991a. Ground-Water Monitoring Program, Calendar Year 1990 Annual Report, Environmental Restoration Program, Sandia National Laboratories, Albuquerque, NM.

SNL/NM (Sandia National Laboratories, New Mexico), 1991b. Compliance Agreement Final Report: Hydrogeological Characterization, Environmental Impact and Restoration Program, Sandia National Laboratories, Albuquerque, NM. 
SNL/NM (Sandia National Laboratories, New Mexico), 1992a. Chemical Waste Landfill Final Closure Plan and Postclosure Permit Application, Environmental Restoration Program, Sandia National Laboratories, Albuquerque, NM.

SNL/NM (Sandia National Laboratories, New Mexico), 1992b. Ground-Water Monitoring Program. Calendar Year 1991 Annual Report, Environmental Restoration Program, Sandia National Laboratories, Albuquerque, NM.

SNL/NM (Sandia National Laboratories, New Mexico), 1993. Ground-Water Monitoring Program: Calendar Year 1992 Annual Report, Sandia National Laboratories, Albuquerque, Environmental Restoration Program, Sandia National Laboratories, Albuquerque, NM.

SNL/E\&E (Sandia National Laboratories and Ecology and Environment), 1990. Report on the Installation of Monitoring Well MW-4 at the Chemical Waste Landfill, unpublished report prepared for Environmental Impact and Restoration Division, Sandia National Laboratories, Albuquerque, NM.

Stein, C., and D. L. McTigue, 1989. Chromium Distribution and Transport Beneath a Contaminated Site, SAND88-1471, Sandia National Laboratories, Albuquerque, NM, $45 \mathrm{pp}$.

Stephens \& Associates (Daniel B.), Inc., 1990a. Laboratory Analysis of Soil Hydraulic Properties from the MW-4 CWL Monitoring Well, unpublished report prepared for Ecology \& Environme tt, Inc., Albuquerque, NM.

Stephens \& Associates (Daniel B.), Inc., 1990b. Laboratory Analysis of Soil Hydraulic Properties from the MW-4 CWL Monitoring Well (130.75 Feet to 253.33 Feet), unpublished report prepared for Ecology \& Environment, Inc., Albuquerque, NM.

Stephens, D. B., and R. G. Knowlton, Jr., 1986. Soil-Water Movement and Recharge Through Sand at a Semiarid Site in New Mexico, Water Resources Research, 22, pp. 881-889.

Theis, C. V., 1938. Ground Water in the Middle Rio Grande Valley, in (U.S.) National Resources Committee, Regional Planning, Part V: Rio Grande Joint Investigation in the Upper Rio Grande Basin in Colorado, New Mexico and Texas, 1936-37, Washington DC, U.S. Government Printing Office, vol. 1, pt. 2, pp. 268-291.

Thomson, B. M., and G. J. Smith, 1985. Investigation of Groundwater Contamination Potential at Sandia National Laboratories, Albuquerque. NM, in Proceedings of the Fifth DOE Environmental Protection Information Meeting, Albuquerque, NM, 6-8 November 1984, CONF-841187, pp. 531-540.

Titus, F. G., 1963. Geology and Ground-Water Conditions in Eastern Valencia County, New Mexico, Bulletin 41, New Mexico Bureau of Mines and Mineral Resources. 
Titus, F. G., 1980. Ground-Water in the Sandia and Northern Manzano Mountains, New Mexico, Hydrologic Report 5, New Mexico Bureau of Mines and Mineral Resources.

USDA (U.S. Department of Agriculture) Soil Conservation Service, 1977, Bernalillo County and Parts of Sandoval and Valencia Counties, New Mexico, prepared by U.S. Department of Agriculture Soil Conservation Service and Forest Service and U.S. Department of the Interior Bureau of Indian Affairs and Bureau of Land Management in cooperation with New Mexico Agricultural Experiment Station, June 1977.

USGS (U.S. Geological Survey), 1992. Water Resources Data New Mexico Water Year 1991, Water-data Report NM-91-1, U.S. Geological Survey, Water Resources Division, Albuquerque, NM, $557 \mathrm{pp}$.

USGS (U.S. Geological Survey), 1993a. Personnel communication with Carole Thomas, U.S. Geological Survey, Water Resources Division, Albuquerque, NM.

USGS (U.S. Geological Survey), 1993b. Personnel communication with Dave Ortiz, U.S. Geological Survey, Water Resources Division, Albuquerque, NM.

U.S. Weather Bureau (no date), Normai Annual Precipitation, 31-1960, State of New Mexico, U.S. Department of Commerce map, 1: 500,000, 1 sheet.

Weston, R. F., 1984. Characterization of the Sandia National Laboratories (SNLA) Chemical Waste Disposal Site, prepared by Roy F. Weston, Inc., for Sandia National Laboratories, Albuquerque, NM.

Wilson, L. G., 1983. Monitoring in the Vadose Zone, Ground Water Monitoring Review, vol. 3 , no. 1 , pp. 155-166.

Yapp, C. J., 1985. D/H Variations of Meteoric Waters in Albuquerque, New Mexico, U.S.A., Journal of Hydrology, vol. 76, pp. 63-84. 


\subsection{HYDROGEOLOGIC CONCEPTUAL MODEL FOR THE SNL/KAFB AREA}

This section describes the overall hydrogeologic CM for the study area. The CM was developed based on information presented in Section 3.0 on the geologic framework and Section 4.0 on the hydrologic framework. In addition, information regarding the potential contaminant sources as well as the likely human receptors was used to develop the CM. Developing a $\mathrm{CM}$ that identifies important transport processes and the interrelationships between those processes is a vital first step in building a predictive quantitative model of flow and contaminant transport in groundwater systems.

Knowing the likely fate and transport behavior of contaminants of concern through the regional hydrogeologic system is prerequisite to assessing the total risk posed by each of the ER sites. Although one would never be able to precisely know a contaminant's ultimate fate and transport behavior, mathematical models might be used to develop an appropriately quantitative understanding. Thus, an overall $\mathrm{CM}$ for the SNL/KAFB area must be developed to permit a defensible risk assessment for each of the ER sites. In addition, a well-defined $\mathrm{CM}$ is required in order to identify and select field characterization activities (see Section 2.0) of the regional hydrogeologic system.

\subsection{Integrated Conceptual Model}

Figure 5-1 is a schematic representation of the current hydrogeologic CM for the SNL/KAFB area. This figure summarizes the major features and conceptual interrelationships between the local geologic and hydrologic environments, and identifies important uncertainties in this CM. A review of this figure from east to west (in the general direction of the regional lateral hydraulic gradient) shows the following important features:

1. Precipitation will contribute to both surface water flow and recharge into and possibly through the vadose zone into the underlying aquifer. Overland flow and diffuse recharge are both potential contaminant transport mechanisms.

2. The majority of the SNL/KAFB area is overlain by a thin alluvial cover that will play host to vadose zone processes [estimated to range from 50 to $150 \mathrm{ft}$ (15 to $46 \mathrm{~m}$ )].

3. In addition to this thin alluvial cover, the vadose zone in subareas 1 and 2 extends deep into the underlying Santa Fe Group. In these subareas, the vadose zone is generally greater than $300 \mathrm{ft}(91.5 \mathrm{~m})$ in thickness.

4. Subarea 4 extends from the Manzanita Mountain-front area west to the Tijeras/Hubbell Spring Fault complex, and is characterized by complex bedrock geology. This subarea might include local unconfined alluvial aquifers, and confined porous media anu fractured rock aquifers. Fracturing might contribute high-permeability pathways for groundwater flow and contaminant transport. 


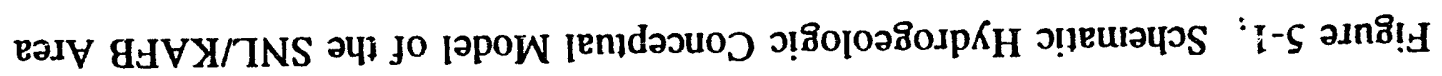

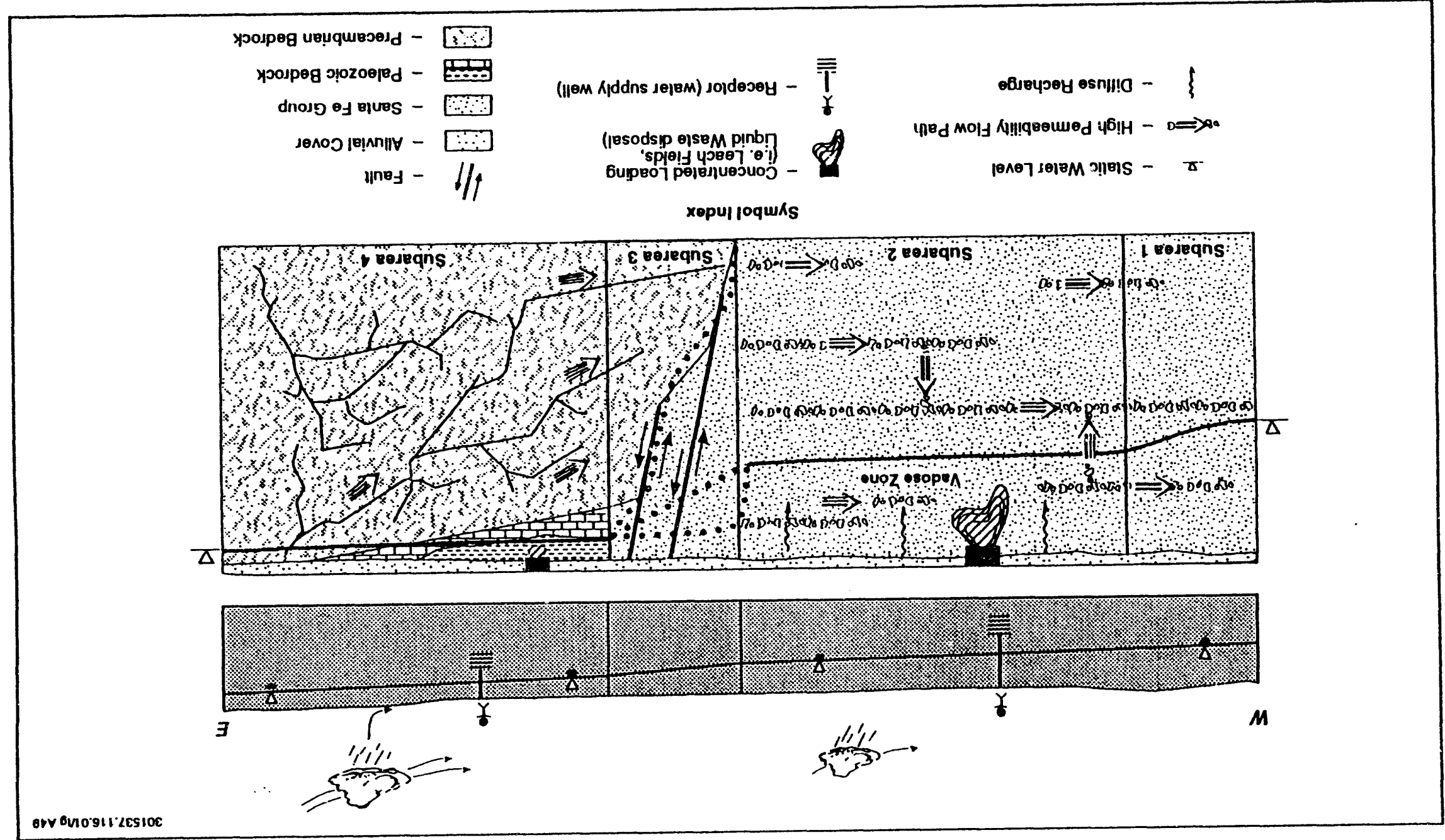


5. Subarea 3 includes the Sandia, Tijeras, and Hubbell Spring Fault complex. There is significant uncertainty on the impact of faulting on groundwater flow. Four scenarios on the impact of the fault complex are: (1) faulting might create a hydraulic discontinuity, leading to a very high lateral hydraulic gradient between one or more subarea-4 aquifers and the uppermost Santa Fe Group unconfined aquifer in subarea 2; (2) faulting might provide a conduit for upward flow from deep, confined aquifers into the shallow Santa Fe Group aquifer; (3) faulting might result in deep recharge from the subarea-4 aquifers into a deeper Santa Fe Group confined aquifer; and (4) faulting might have a minor impact on the hydraulic connection between subareas 2 and 4 .

6. The Santa Fe Group underlying subareas 1 and 2 is characterized by a complex hydrostratigraphic architecture. This complexity will result in highly variable aquifer characteristics. These characteristics might include the opportunity for perched aquifers, locally confined conditions, high-permeability flow paths, and significant vertical gradients between distinct Santa Fe Group aquifers.

7. Subarea 1 is within the radius of influence of the KAFB water-supply well field. The local transients associated with groundwater pumping will have a strong impact on the flow field in this subarea. This well field is a major groundwater receptor.

\subsection{Uncertainties in the Conceptual Model}

Figure 5-1 presents a summary schematic diagram of the overall CM, but does not identify the topics/areas of uncertainty. In each component of the hydrogeologic system (surface water, vadose, and saturated zones) are a number of uncertainties that detract from our ability to predict fate and transport of contaminants. The only way to reduce these uncertainties is through well-focused field characterization. Whereas characterization of individual ER sites will be the focus of upcoming RFI activities, the SWHC project will focus on developing information and reducing uncertainties with respect to generic, site-wide hydrolcgic processes.

\subsubsection{Surface Water and Vadose Zone Uncertainties}

The surface water regime can affect contaminant transport by erosion, sediment transport, and subsequent infiltration into the vadose zone. The net effect is a surficial redistribution of waste sources, which can greatly complicate our ability to predict transport. There are currently no site-specific data regarding rainfall run-off relationships, erosion characteristics, and channel flow and infiltration. Although we know that as many as six of the ER sites lie within the flood-prone areas, as identified by the COE (1979), it is possible (if not likely) that some of the ER sites with surficial contamination that lie outside the flood-prone areas also might be subject to source redistribution by surface processes.

Because of the spatial and temporal variability in the climatic conditions (the surface boundary for the vadose zone) and the surface hydrologic redistribution of precipitation, the total water flux in the near-surface soil is highly variable. Presumably, as the water moves deeper into the vadose zone, the natural lateral variability in moisture fluxes should be attenuated. Besides the natural water fluxes, locations of near-surface spills (e.g., leaking 
tanks) and concentrated effluent loading (e.g., septic tank leachfields) can cause the development of moisture plumes such as that depicted in Figure 5-1. As noted in section 4.3.1, both the mode of fluid flow and its magnitude are highly uncertain. For instance, one can not rule out the existence of preferential flow paths through the vadose zone (which would significantly reduce contaminant travel time and attenuation), particularly beneath effluent sources. Additional large uncertainties exist regarding the natural recharge rates as well as the dispersion/dilution characteristics of thick vadose zones. The possibility of contaminant interaction and movement in separate phases (gas phase or separate liquid phase) must also be recognized and addressed. These and other aspects of the overall CM will be investigated as part of the SWHC.

\subsubsection{Saturated Zone Processes}

As implied by Figure 5-1 and discussed in Section 5.1, the saturated zone underlying the $\mathrm{SNL} / \mathrm{KAFB}$ area is highly complex. This complexity in turn contributes uncertainty to characterizing groundwater flow and transport. Subdividing the SNL/KAFB area helps to reduce this area-wide complexity. However, even within the individual subareas, the local hydrogeologic framework retains significant complexity and uncertainties. Uncertainties include aquifer-type identification, quantification of effective hydraulic parameters (permeability, porosity, and compressibility), lateral and vertical hydraulic gradients, identification of high-permeability flow paths, aquifer transport characteristics (dispersivity, dispersion, distribution coefficient, and contaminant degradation), and boundary conditions associated with the fault complex.

\subsubsection{Aquifer-Type Identification}

Preliminary assessment of ongoing ER Program RFIs suggests that the uppermost aquifer in the Santa Fe Group is not necessarily unconfined as generally accepted (e.g., perched intervals and confined conditions have also been identified). In addition, there is potential for multiple aquifers in different geologic media (e.g., porous media aquifers and fractured rock aquifers) in subarea 4 . This potential for variability in aquifer type needs to be explicitly considered to ensure valid comparison of water levels from various locations.

\subsubsection{Effective Hydraulic Parameters}

The variability in the sedimentary lithotypes (unconsolidated cobb'e conglomerates to clay) and the presence of fractured rock in the saturated zone result in a highly heterogeneous and anisotropic mix of hydraulic parameters. These characteristics lead to both local parameter uncertainty and uncertainty in extrapolation of parameters between different locations.

\subsubsection{Hydraulic Gradients}

The mix of different aquifer types and the heterogeneous lithologies lead to uncertainty in both horizontal and vertical hydraulic gradients. Horizontal gradient uncertainty is related to correlating water levels from different aquifers to define a characteristic potentiometric surface (i.e., mixing apples and oranges). The potential for locally significant vertical gradients in the saturated zone underlying the SNL/KAFB area has been demonstrated. 
However, the controls on vertical gradients (lithologic and/or structural) have not been identified, and there is significant uncertainty in the three-dimensional distribution of vertical gradients.

\subsubsection{High-Permeability Flow Paths}

High-permeability flow paths can be expected based on the heterogeneous stratigraphy and the presence of fractured rock. However, the presence of high-permeability flow paths between contaminated sites and receptors is uncertain.

\subsubsection{Transport Parameters}

The variability in the hydrogeologic framework and the range of different types of contaminants create many uncertainties in transport parameters. The magnitude and mix of these parameters could vary significantly at individual locations as well as between locations.

\subsubsection{Boundary Conditions at the Fault Complex}

The impact of the fault complex on site-wide horizontal and vertical groundwater flow is currently uncertain; that is, does the fault complex constitute a no-flow boundary, a constanthead boundary, or no boundary at all?

\subsection{Conceptual Model to Quantitative Predictive Model}

To be useful for quantitative prediction, the $\mathrm{CM}$ will be implemented into appropriate mathematical models. Although it would be desirable to have a model that integrates all features of the CM, the complexity of the overall system dictates that a number of component models be built. The need for a number of different component models emanates from the variety and complexity of the various aspects of the total hydrogeologic CM.

At the input end for the hydrogeologic $\mathrm{CM}$ are the surficial processes (iainfall run-off and sediment transport), and this component certainly must be modeled independent of the subsurface flow and transport models (Goodrich and Woolhiser 1991). There will be a direct linkage, however, in the channel/infiltration-loss aspects of the surficial process models and the vadose zone flow model. The vadose zone flow modeling will consist of at least two related approaches; the first will look at multidimensional transport processes that account for lateral flow and mixing, and the second will employ the results of the first to estimate overall one-dimensional (vertical) contaminant movement. The multidimensional vadose modeling will be particularly useful for assessing concentrated effluent sources, whereas the second is more applicable to leaching and subsequent transport under natural recharge conditions. The fluid and solute fluxes predicted out of the bottom of the vadose zone will be used as input for the top boundary for saturated zone modeling. Given the four distinct hydrogeologic subareas in the saturated zone (see Sections 4.4 and 5.2.2), we might need to use a variety of models for the phreatic zone, or perhaps implement a single hybrid model. Possible 
saturated zone models include fracture flow models in subarea 4 (bedrock aquifers in the eastern region of SNL/KAFB), and porous media models for the areas west of the fault system. Where data availability permits and performance measure computation requires, three-dimensional modeling will be used for the saturated zone.

In most cases, we will employ numerical models to simulate the system. Numerical models require one to discretize the spatial domain of interest into a mesh of gridblocks, and modeling results (e.g., groundwater velocities) are obtained as an average value for each gridblock. As described by Sudicky and Huyakorn (1991), numerical modeling of fluid flow and contaminant transport in heterogeneous geologic media is an extremely difficult problem, particularly for unsaturated (vadose zone) and multiphase flow. The numerical difficulties for unsaturated flow result from the nonlinearity of the mathematics used to model such systems. These nonlinearities lead to extremely long central processing unit times required to solve problems with a large number of gridblocks. Because we are interested in assessing aspects of the hydrogeologic system such as fast flow paths through heterogeneous geologic environments, we must use gridblocks that are as small as computationally possible. The requirement of small gridblocks applied of a region of more than $100 \mathrm{mi}^{2}\left(259 \mathrm{~km}^{2}\right)$ that is potentially several thousand feet thick implies a numerical mesh with over 10 million gridblocks. Thus, it would be nearly impossible computationally to simulate the entire $\mathrm{SNL} / \mathrm{KAFB}$ region at the required grid resolution. Where possible, we will also employ analytical mathematical models, which are much less computationally burdensome; one possible example would be using one-dimensional transfer function models (Jury and Roth 1990) to assess contaminant movement through the vadose zone under natural recharge conditions.

\subsection{Summary of SNL/KAFB Hydrogeologic Modeling}

A CM has been developed for the SNL/KAFB hydrogeologic system. This CM accounts for all relevant hydrogeologic processes from the surficial processes to the vadose zone processes to the saturated zone processes. This CM will be implemented as required by mathematical models that will permit us to make quantitative predictions regarding behavior of the total hydrogeologic system. The CM will also be used to help guide field characterization activities to support the overall ER Program.

\subsection{References}

COE (U.S. Army Corps of Engineers), 1979. Special Flood Hazard Information, Tijeras Arroyo and Arroyo del Coyote, Kirtland AFB, New Mexico, U.S. Army Corps of Engineers, Albuquerque District, Albuquerque, NM.

Goodrich, D. C., and D. A. Woolhiser, 1991. Catchment Hydrology, in Contributions in Hydrology, U.S. National Report for 1987-1990, American Geophysical Union, Washington, DC, pp. 202-209.

Jury, W. A., and K. Roth, 1990. Transfer Functions and Solute Movement Through Soil: Theory and Applications, Birkhauser, Verlag, Basel, 226 pp. 
Sudicky, E. A., and P. S. Huyakorn, 1991. Contaminant Migration in Imperfectly Known Heterogeneous Groundwater Systems, in Contributions in Hydrology, U.S. National Report for 1987-1990, American Geophysical Union, Washington, DC, pp. 240-253. 



\section{DISTRIBUTION:}

2 U.S. Department of Energy (DOE/AL)

Environmental Restoration

Project Office

ATTN: Julianne Levings

P. O. Box 5400

Albuquerque, NM 87185-5400

15 U.S. Department of Energy Kirtland Area Office (KAO) ATTN: Sue E. Umshler (15) Environment, Safety, Health, and Compliance Branch

P. O. Box 5400

Albuquerque, NM 87185-5400

10 U.S. Department of Energy

Kirtland Area Office (KAO)

ATTN: John Gould

Environment, Safety, Health, and Compliance Branch

P. O. Box 5400

Albuquerque, NM 87185-5400

3 New Mexico Environment

Department

ATTN: Mike duMond

c/o DOE-KAO-ESHCB

P. O. Box 5400

Albuquerque, NM $87185-5400$

1 U.S. Environmental Protection Agency (EPA)

Region VI Office

1445 Ross Ave.

Dallas, TX 75202-2733

1 Albuquerque City

Environmental Services

400 Marquette Ave.

Albuquerque, NM 87117
1 John Hawley

New Mexico Bureau of Mines and Mineral Resources

New Mexico Tech 2808 Central Avenue, SE

Albuquerque, NM 87106

3 Mike Kernodle

U.S. Geological Survey

Albuquerque District Office

Su'te 200, Pinetree Office Park

4501 Indian School Road, NE

Albuquerque, NM 87110

1 Harry Davidson

$1606 \mathrm{ABW} / \mathrm{DEEV}$

KAFB, NM 87117-5000

1 J. J. Thompson

Inhalation Toxicology Research Institute

P. O. Box 5800

Albuquerque, NM 87185

1 Bill White

U.S. Department of Interior

Bureau of Indian Affairs

Albuquerque Area Office

Branch of Rights Protection

615 First Street, NW

P. O. Box 26567

Albuquerque, NM 87125-6567 


\section{DISTRIBUTION (Internal):}

\begin{tabular}{|c|c|c|c|c|c|}
\hline OTY & $\underline{\mathrm{MS}}$ & & QTY & $\underline{\mathbf{M S}}$ & \\
\hline 1 & 0719 & J.D. Betsill, 6621 & 1 & 1348 & R.G. Knowlton, 7583 \\
\hline 1 & 0727 & D. Crowson, 6622 & 1 & 1348 & O.D. Laursen, 7583 \\
\hline 1 & 0727 & B. Galloway, 6622 & 1 & 1348 & C.A. Lojek, 7585 \\
\hline 1 & 0727 & B. Langkopf, 6622 & 1 & 1348 & J.F. Matlock, 7583 \\
\hline 50 & 0727 & J.T. McCord, 6622 & 1 & 1348 & M.D. McVey, 7585 \\
\hline 1 & 0727 & A.M. Parsons, 662 & 1 & 1348 & M.M. Mitchell, 7585 \\
\hline 2 & 0750 & D. Gibson, 6116 & 1 & 1348 & R.D. Nieri, 7585 \\
\hline 1 & 0750 & J. Krumhansl, 6118 & 1 & 1348 & G.L. Peace, 7585 \\
\hline 1 & 1305 & C. Olguin, 7574 & 1 & 1348 & D.W. Reaber, 7585 \\
\hline 1 & 1315 & T. Blejwas, 7500 & 1 & 1348 & D.J. Sandhaus, 7585 \\
\hline 1 & 1324 & R. Glass, 6115 & 1 & 1348 & C.J. Sheats, 7585 \\
\hline 1 & 1328 & A.H. Treadway, 6342 & 1 & 1348 & R.P. Thomas, 7583 \\
\hline 1 & 1345 & W.R. Strong, 6331 & 1 & 1348 & M.E. Young, 7585 \\
\hline 1 & 1347 & C.A. Aas, 7582 & 1 & 1350 & B.E. Gaither, 7584 \\
\hline 1 & 1347 & J.E. Brinkman, 7582 & 3 & 1350 & F.C. Lauffer, 7584 \\
\hline 1 & 1347 & R. Conway, 7582 & 3 & 1350 & J.P. McCord, 7584 \\
\hline 1 & 1347 & J. Copland, 7582 & 1 & 1350 & D. Stermer, 7584 \\
\hline 1 & 1347 & W. Cox, 7581 & 1 & 1350 & S. Young, 7584 \\
\hline 1 & 1347 & L. Dawson, 7582 & & & \\
\hline 1 & 1347 & J.T. Holsinger, 7582 & & & \\
\hline 1 & 1347 & R. Holt, 7582 & 1 & 1309 & ER Records Center, 7512 \\
\hline 1 & 1347 & D.R. Miller, 7582 & 1 & 1309 & Environmental Programs \\
\hline 1 & 1347 & F.B. Nimick, 7582 & & & Library, 7512 \\
\hline 1 & 1347 & J.A. Roybal, 7582 & 1 & 9018 & Central Technical Files, \\
\hline 1 & 1347 & P. Slavin, 7582 & & & $8523-2$ \\
\hline 1 & 1348 & C.P. Ardito, 7585 & 5 & 0899 & Technical Library, 7141 \\
\hline 1 & 1348 & D.R. Bleakly, 7583 & 1 & 0619 & Technical Publications, \\
\hline 1 & 1348 & L. Brouillard, 7585 & & & 7151 \\
\hline 1 & 1348 & C.S. Byrd, 7585 & 10 & 0100 & Document Processing for \\
\hline 1 & 1348 & R.E. Fate, $7 ذ 85$ & & & DOE/OSTI, 7613-2 \\
\hline 1 & 1348 & J.A. Fernandez, 7583 & & & \\
\hline 1 & 1348 & T.J. Goering, 7585 & & & \\
\hline
\end{tabular}

D-2 

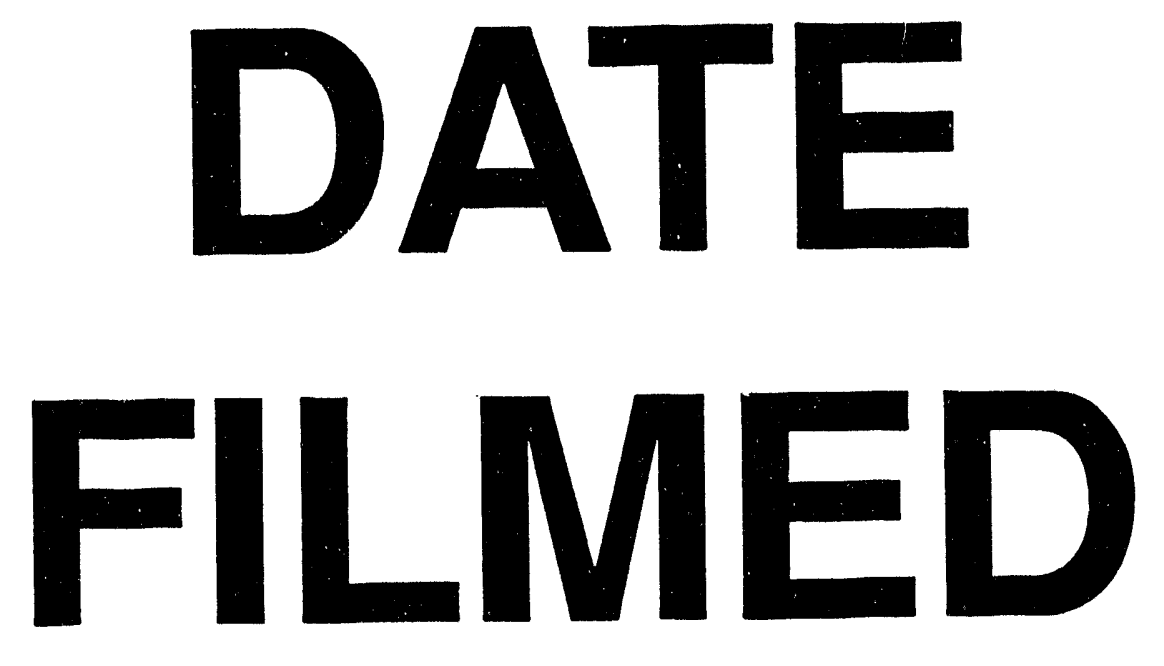

$8 / 19 / 94$
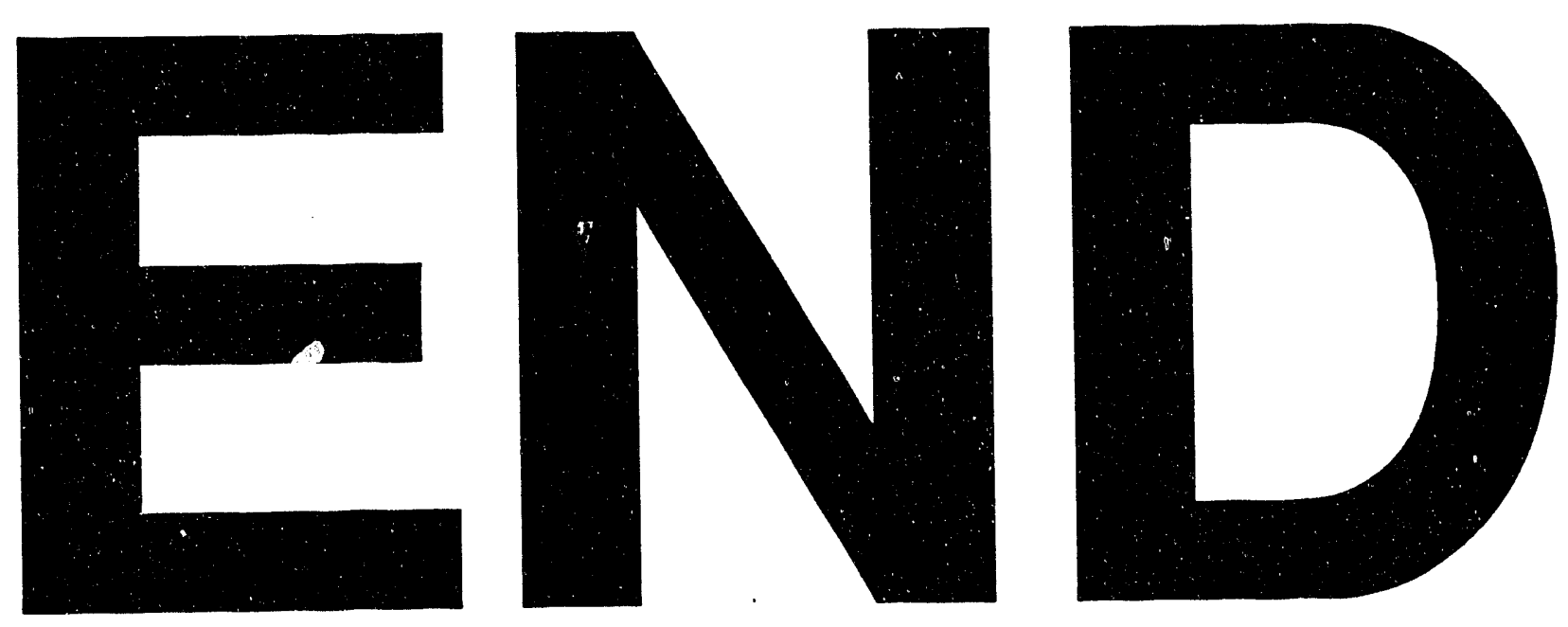

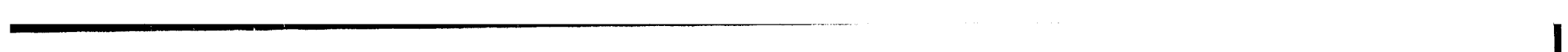
.

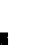

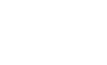

